\title{
ANÁLISE DA LEGITIMIDADE DA PROTEÇÃO PENAL DA ORDEM ECONÔMICA
}

\begin{abstract}
Tese apresentada como requisito parcial para obtenção do título de Doutor em Direito Penal no curso de Pós-Graduação da Faculdade de Direito da Universidade de São Paulo.
\end{abstract}

Orientador: Professor Titular Miguel Reale Júnior

Faculdade de Direito da Universidade de São Paulo São Paulo 
ANÁliSE DA LEGITIMIDADE DA PROTEÇÃO PENAL DA ORDEM ECONÔMICA 


\title{
ANÁLISE DA LEGITIMIDADE DA PROTEÇÃO PENAL DA ORDEM ECONÔMICA
}

\author{
Tese apresentada como requisito parcial \\ para obtenção do título de Doutor em \\ Direito Penal no curso de Pós-Graduação \\ da Faculdade de Direito da Universidade de \\ São Paulo.
}

Orientador: Professor Titular Miguel Reale Júnior

Faculdade de Direito da Universidade de São Paulo São Paulo 
Those who desire to give up freedom in order to gain security will not have, nor do they deserve, either one. THOMAS JEFFERSON 


\section{RESUMO}

A imperiosidade de uma eficaz tutela do ambiente econômico parece indiscutível nos dias atuais. A estrutura do sistema capitalista pós-industrial revela, contraditoriamente, características não desejadas pelo próprio modo de produção vigente, o que a sociologia contemporânea entende ser o consectário da reflexividade da sociedade do risco. Neste sentido, os agentes econômicos empreendem comportamentos atentatórios à conformação econômica da sociedade, pondo em risco o regular funcionamento da própria economia. Nesse contexto, o Direito, mormente o campo penal, é utilizado para tentar rechaçá-los. Ocorre que tal emprego do ramo jurídico-criminal entra em confronto com seus tradicionais contornos, delineados desde a Ilustração. Complexas condutas econômicas são penalmente vedadas, no mais das vezes por meio de formulações tipificadoras antecipatórias, pouco consistentes e com caráter de meio de conformação de comportamentos de alçada administrativa, consagrando-se a administrativização do ramo jurídico-criminal. O presente estudo tem, então, por objetivo investigar a legitimidade do Direito Penal Econômico. Inicialmente, analisar-se-á o histórico da intersecção entre Direito Penal e economia, para fins de constatação de um possível traço evolutivo. A seguir, delimitar-se-á o que se entende por Direito Penal Econômico, bem como se seria necessário e possível subsumi-lo à teoria do bem jurídico. Uma vez identificada a ordem econômica como objeto de tutela penal, serão verificados seus contornos no ordenamento brasileiro, assim como os problemas dogmáticos decorrentes de sua construção. Após isso, serão investigadas, respectivamente, e de modo complementar, a tentativa de tutela penal da ordem econômica em face do conceito de lesividade penal, vez que se sinaliza neste ponto larga vulneração das formulações típicas comumente editadas, bem como a possibilidade, ou não, de justificação da tutela penal na seara econômica em razão da teoria da cumulatividade delitiva, a qual prescinde da aferição de lesividade concreta. Serão constatadas, seqüencialmente, teorias que pretendem equacionar a administrativização do Direito Penal hodierno, destacando-se a proposta administrativo-sancionadora. Por fim, concluir-se-á pela melhor construção jurídica a regrar as infrações econômicas, delimitando-se o papel do Direito Penal neste contexto.

Palavras-chave: Ordem econômica - Teoria do Bem Jurídico - Direito Penal Econômico Legitimidade - Direito Administrativo Sancionador 


\begin{abstract}
The imperiousness of effective protection of the economic environment seems undeniable today. The structure of post-industrial capitalist system reveals, paradoxically, features unwanted by the existing mode of production, which the contemporary sociology understands as the reflexivity of risk society. In this sense, the economic agents undertake conduct detrimental to the conformation of the economic society, undermining the smooth functioning of the economy itself. In this context, the law, especially the criminal law, is used to try to head them off. It happens that such employment of legal and judicial branch clashes with their traditional boundaries, delineated since the Enlightenment. Complex economic behavior are criminally prohibited, in most cases through typifying proactive formulations, which are inconsistent and display as mere means of behavioral conformation, subject to administrative jurisdiction, which leads to the administrativization of the criminal law. The present study is then undertaken to investigate the legitimacy of Economic Criminal Law. Initially, it will examine the history of the intersection between criminal law and economy, aiming at finding a possible evolutionary trait. Then it will define what is meant by Economic Criminal Law, and whether it would be necessary and possible to subsume it to the protected interest theory. Having identified the economic order as an object of penal protection, its outlines will be verified in the Brazilian legal system, as well as problems arising from its dogmatic construction. After that will be investigated, respectively, and in a complementary way, the attempt to the penal protection of the economic order in the face of the concept of criminal harmfulness, since it signals at this point a violation from the typical formulations commonly edited, and the possibility or not of justification of the penal protection in the economic area because of the theory of cumulative criminal offense, which dispenses with the measurement of actual harmfulness. Will be analyzed sequentially, theories that intend to equate the administrativization of criminal law, highlighting the proposed administrative-punitive. Finally, the conclusion will be the search for the best legal construction of the rules for economic infractions, limiting the role of criminal law in this context.
\end{abstract}

Keywords: Economic system - Protected Interest Theory - Economic Criminal Law Legitimacy - Administrative Law sanctioning 


\section{RIASSUNTO}

L'imperiosità di un'efficace tutela dell'ambiente economico pare indiscutibile nei giorni attuali.La struttura del sistema capitalista postindustriale mostra, invece, caratteristiche non desiderate dal proprio modo di produzione vigente, quel che la società contemporanea intende essere il risultato della riflessibilità della societrà di rischio.In questo senso, gli agenti economici impiegono attegiamenti attentatori alla conformazione economica della società, mettendo in rischio il regolare funzionamento dell'economia stessa. Così, il Diritto, più spesso il campo penale, è utilizzato per cercare di rifiutarli. Occorre che tale impiego del branco giuridico criminale va contro i suoi tradizionali contorni, delineati sin dall'Illustrazione. Complesse condotte economiche sono penalmente vietate, per lo più attraverso formulazioni antecipatorie, però consistenti e con carattere di mezzo di conferma di attegiamenti di portata amministrattiva, consacrandosi l'amministrattivazione del branco giuridico criminale. Il presente scritto ha, allora, per scopo ricercare la leggitimità del Diritto Penale Economico. Inanzitutto, si analizzerà lo storico dell'intersezione fra Diritto Penale ed economia, con la finalità di constattare un possibile tratto evolutivo. In seguito, si delimiterà quel che si capisce per Diritto Penale Economico, ben come se sarebbe necessario e possibile collegarlo alla teoria del bene giuridico. Una volta idividuato l'ordine economico come oggetto della tutela penale, saranno verificati i suoi contorni nell'ordinamento brasiliano, così come i problemi dogmatici decorrenti della sua costruzione. Dopodiché, saranno investigati rispettivamente, e di modo complementare, il tentativo di tutela penale dell'ordine economico visto il concetto di lesione penale, giacché si sinalizza in questo punto larga vulnerazione delle formulazioni tipiche comumente editate, così come la possibilità, o meno, di giustificazioni della tutela penale nella sfera economica in virtù della teoria della cumulatività delittiva, la quale prescinde dell'afferenza della lesitività concreta. Saranno constattati, inoltre, teorie che pretendono risolvere l'amministrattivazione del Diritto Penale odierno, risaltandosi la proposta amministrattivo sanzionatoria. Infine, si concluderà per la miglior costruzione giuridica a reggerer le infrazioni economiche specificandosi il ruolo del Diritto Penale in questo contesto.

Parole chiave: Ordine economico - Teoria del bene giuridico - Diritto penale Economico 


\section{SUMÁRIO}

RESUMO.

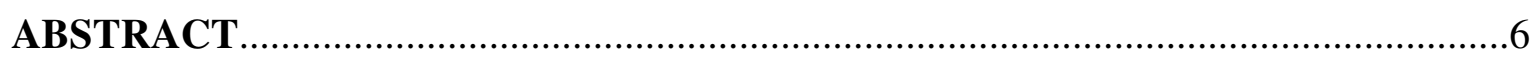

RIASSUNTO

INTRODUÇÃ

1. ORDEM ECONÔMICA: CONCEITUAÇÃO E TENTATIVAS DE TUTELA

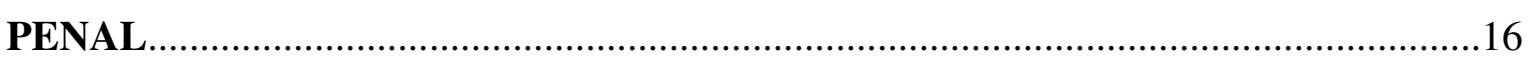

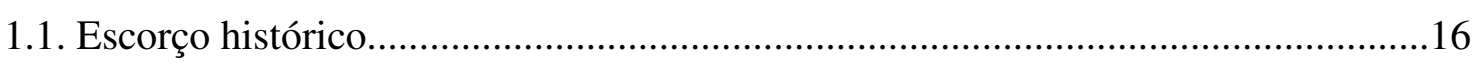

1.1.1. Primeira fase: casuísmo legislativo............................................................ 17

1.1.2. Segunda fase: proteção ao liberalismo...............................................................19

1.1.3. Terceira fase: Estado do Bem-Estar Social....................................................21

1.1.4. Quarta fase: retração do papel do Estado.......................................................25

1.1.5. A delinqüência econômica no Brasil............................................................28

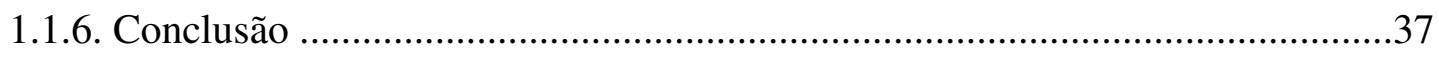

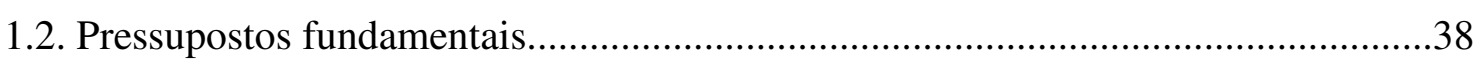

1.2.1. A compreensão de Direito Penal Econômico.....................................................38

1.2.1.1. A proteção de bens jurídicos como referência interpretativa material do

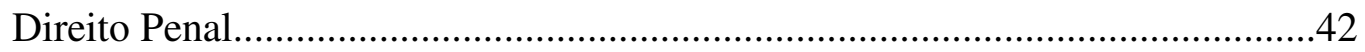

1.3. Aproximação ao conceito de ordem econômica......................................................52

1.4. A confiança como elemento necessário para a reprodução e circulação da

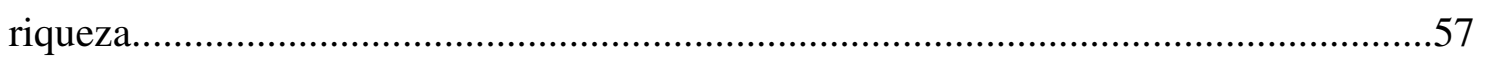

1.5. A experiência penal de garantia da ordem econômica na legislação brasileira

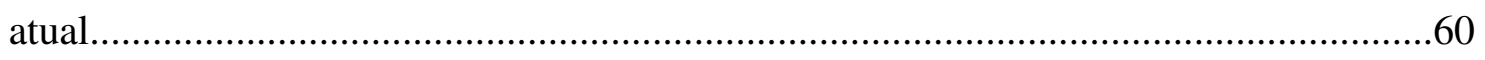

1.6. Problemas dogmáticos do Direito Penal Econômico.............................................63

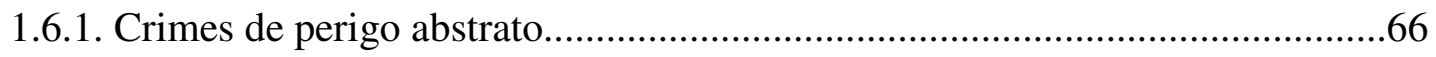

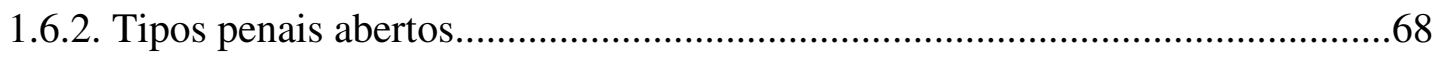

1.6.3. Tipos penais de assessoriedade administrativa............................................. 70 


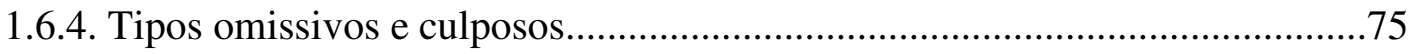

1.6.5. A incoerência do discurso legitimador dos fins da pena.................................77

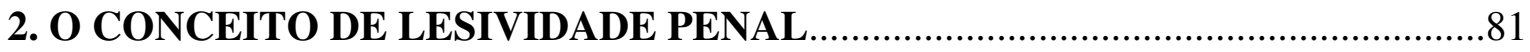

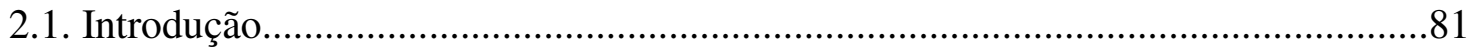

2.2. A lesividade no pensamento penal clássico.............................................................83

2.2.1. Princípio da lesividade e crimes de perigo abstrato........................................85

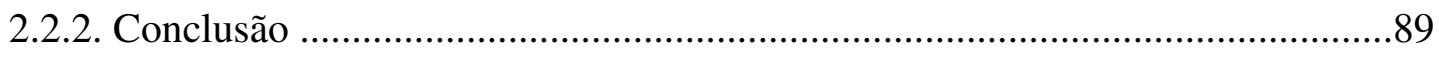

2.3. A lesividade como transgressão ao ordenamento.................................................91

2.3.1. Referências críticas e conclusão ...................................................................95

2.4. A busca da demarcação da lesividade nos crimes econômicos.................................97

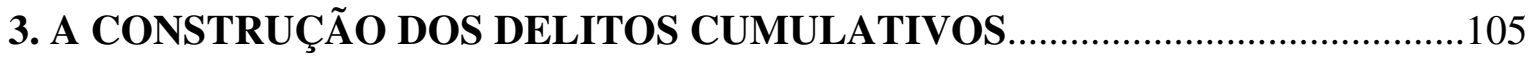

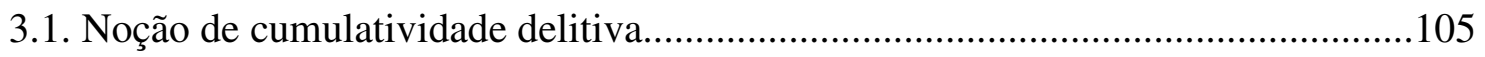

3.2. O surgimento pragmático do conceito de cumulatividade....................................108

3.3. Perspectiva fundamentadora filosófica: a questão do free-rider ............................111

3.4. Crimes cumulativos como crimes de perigo ou crimes de resultado.....................113

3.5. Cumulatividade e a reconstrução da lesividade penal............................................115

3.6. Delitos cumulativos e sua capacidade justificadora da tutela penal econômica.....119

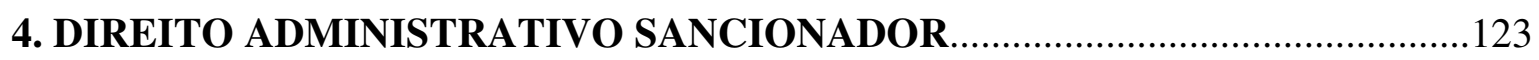

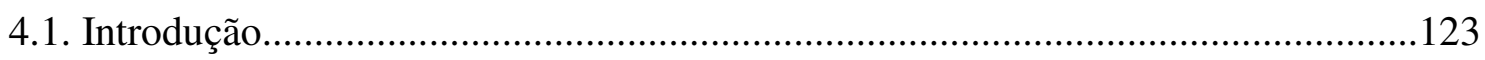

4.2. A Escola da Frankfurt e o discurso de resistência à expansão do Direito Penal....125

4.3. A proposta de WINFRED HASSEMER: o Direito de Intervenção........................126

4.4. A proposta de SILVA SÁNCHEZ: o Direito Penal de duas velocidades...............129

4.5. A leitura administrativo-sancionadora no Brasil.....................................................133

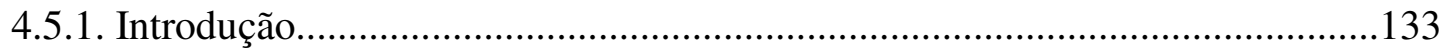

4.5.2. Diferenciação entre o ilícito administrativo e o ilícito penal..........................135

4.5.3. Razões alegadas para a utilização do Direito Administrativo Sancionador....142

4.5.4. Propostas para o aperfeiçoamento do Direito Administrativo Sancionador...144 4.5.4.1. Adoção do princípio da legalidade................................................. 145 
4.5.4.2. A flexibilização da aferição do elemento subjetivo na hipótese, com uma presunção de dolo

4.5.4.3. O estabelecimento da solidariedade entre a empresa e seu dirigente na imputação da prática de infração à ordem econômica.

4.5.4.4. A fixação de normas relativas às causas dirimentes escoradas na

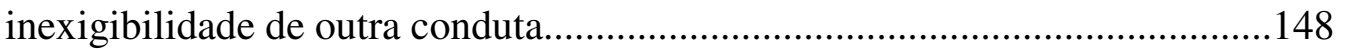

4.5.4.5. A previsão do erro de tipo e de força maior, a excluir a sanção..........148

4.5.4.6. O regramento preciso da individualização da sanção 149

4.5.4.7. A contemplação de causas de extinção da punibilidade e prescrição sancionatória.

4.5.4.8. Erigimento de um sistema processual adequado, com independência orgânica.

5. O DIREITO PENAL E AS INFRAÇÕES ECONÔMICAS.

5.1. Introdução 155

5.2. Os discursos de criminalização difusa. 156

5.3. A tutela da ordem econômica - finalidade e eficiência: deslegitimação do Direito

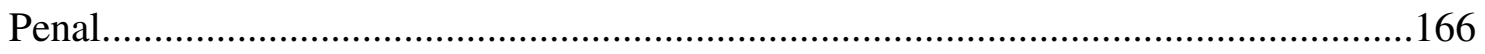

5.4. As opções jurídicas como lege ferenda ...............................................................170

CONCLUSÕES 


\section{INTRODUÇÃO}

O questionamento da legitimidade do ramo jurídico-penal na tentativa de controle da ordem econômica é o foco da presente investigação científica. Referida análise será delimitada pelo confronto da constatação legal da tutela penal econômica, identificada como reveladora do fenômeno da administrativização do Direito Penal, em tensão com o caráter de lesividade deste e, ainda, a teoria da cumulatividade delitiva.

Noções de Direito Econômico e Direito Administrativo serão, portanto, instrumentos a serem utilizados no curso da tese de doutoramento, em face da ciência jurídico-penal, relativamente à qual se focará, principalmente, a expansão do Direito Penal Econômico em contradição com as características fundamentais da dogmática penal, desenvolvidas desde a Ilustração.

O Direito Penal contemporâneo claramente ostenta um caráter hipertrofiado, expandido, envolto em uma situação-limite existencial sem precedentes. Para além da constatação, em níveis globais, de transformação em tábula rasa do princípio da ultima ratio, erigindo-se à categoria de crimes os mais diversos novéis interesses sociais, mormente ainda pouco sedimentados pela sociedade, promanam formulações tipificadoras de duvidosa consistência.

Assim é que o legislador vem cuidando de interesses supra-individuais, e, deste modo, etéreos, pelo ramo jurídico-penal, bem como cedendo a pressões sociais por tutela preventiva de certos temas pela formulação criminalizadora, avultando o aspecto simbólico do Direito Penal. E mais: em verdadeiro círculo vicioso deslegitimador do mais grave meio de controle social, uma vez constatada a incapacidade de tal ramo jurídico para a tutela de específicos bens, ou mesmo como fomentador de comportamentos humanos tidos como positivos, a solução é o agravamento repressor, esgarçando-se a postura punitiva.

Não bastassem as dificuldades de assimilação de interesses inéditos e pouco palpáveis por uma sociedade complexa, globalizada, multifacetada, permeada de grupos 
conflitantes, a tutela penal ainda abusa de formulações pouco consistentes. É o que ocorre, por exemplo, com a constante utilização de categorias de perigo abstrato, normas penais em branco, tipos culposos e abertos, comprometendo-se mais ainda a pretendida eficácia da drástica opção pela tutela criminal.

É neste contexto de desconstrução do paradigma liberal do Direito Penal, mitigando-se o princípio da legalidade, ostentando-se uma desenfreada tipificação e cerceando-se garantias dos imputados, que o ramo jurídico-criminal vem tentando intervir na ordem econômica, o que justifica o estudo pretendido. E isto se dá em razão não apenas de se questionar a real necessidade desta postura legislativa, como também em face de suas sérias conseqüências sociais.

A globalização, por seu turno, tenciona ainda mais a situação no sentido do alargamento das fronteiras do Direito Penal Econômico. Se a globalização é, Se a globalização é, antes de tudo, um fenômeno econômico de reafirmação do modo de produção capitalista, consistente no estreitamento dos agentes de produção de riquezas, ignorando-se as fronteiras nacionais, com o fomento da interligação econômica, da divisão de trabalho e de etapas produtivas, de distribuição de produtos e da facilitação de consumo e assunção de capital, o sistema econômico atual revela características únicas de uma modernização reflexiva, isto é, de exasperação, ou radicalização, de seus característicos tradicionais.

Neste influxo, os agentes econômicos buscam o recrudescimento de fórmulas de controle social para revalidação de seus próprios valores. O Direito Penal, então, é usado pelo sistema capitalista globalizado contemporâneo como opção pretensamente eficiente e garantidora do correto funcionamento das forças produtivas.

A representação jurídica do modelo sócio-econômico em foco consagra o erigimento à categoria de infrações penais das mais variadas e complexas condutas supostamente atentatórias ao modelo econômico vigente. Assim é que os crimes ditos contra a ordem econômica e financeira, contra o meio ambiente, contra as relações de 
consumo, contra a ordem tributária, de lavagem de dinheiro, etc., encontram-se dentro desta contextualização, genericamente entendida como delinqüiência econômica.

O Direito Penal se vê, desta maneira, como pretenso assegurador da normalidade sistêmica econômica, restando atônitos todos os atores da repressão criminal. Na prática, o que parece despontar é a deslegitimação do ramo jurídico-penal diante de sua tibieza no controle de tais situações.

Em face destas constatações, imperioso o estudo da legitimidade penal relativamente à ordem econômica. Citado ramo do Direito vem ostentando o característico de tutela antecipada a situações muitas vezes de alçada do Direito Administrativo, daí falar-se em sua administrativização, o que é posto em xeque diante da necessária lesividade penal justificadora da tipificação de condutas, mas, de outra sorte, talvez escorada no alicerce teórico da construção dos delitos cumulativos, temário com o qual se pretende confrontar. Esta última construção teórica, uma vez afrontada pela ausência de lesividade a um bem jurídico por uma conduta individual, entende justificar-se a tipificação em razão do fato de que o conjunto de comportamentos - pela realização de condutas pela coletividade - culminaria pela lesão ao citado bem.

Destarte, a complexa realidade dogmático-penal hodierna se vê paradigmaticamente posta em face da busca regulatória econômica por este gravoso meio de controle social, o que será analisado por meio da presente tese de doutorado, visando-se apurar sua legitimidade para tanto, ofertando-se à comunidade jurídica um novel contributo orientador científico.

Neste sentido, o temário proposto à investigação científica perpassa por específicas questões fundamentais as quais subsidiarão as conclusões pretendidas - e que permearão os capítulos do presente trabalho -, a saber:

No capítulo 1, após um panorama histórico quanto à intersecção entre Direito Penal e Economia, será investigado o que se entende doutrinariamente por Direito Penal Econômico, bem como sua relação com a teoria do bem jurídico. A seguir, será procedida 
uma aproximação ao conceito de ordem econômica, tido como basilar para se permitir a identificação da tutela jurídico-penal voltada a tanto. Neste diapasão, bem como diante da necessária constatação da comunicação lingüística dos atores penais para a conclusão desvalorativa de uma conduta, a confiança há de ser analisada como importante elemento para a reprodução e circulação de riquezas.

Notando-se a experiência penal de garantia do sistema econômico na legislação contemporânea, permitir-se-á a construção de críticas e questionamentos ao Direito Penal Econômico, fomentados, como citado, pela utilização de formulações porosas e antecipatórias da tutela repressiva, tais como a dos tipos abertos, dos tipos de assessoriedade administrativa, destacando-se as normas penais em branco, dos crimes de perigo abstrato, dos tipos omissivos e dos crimes culposos. Neste contexto, constatar-se-ão as contradições do discurso legitimador dos fins da pena para tal específico enfoque penal.

A seguir, no capítulo 2, a pesquisa confrontará a tentativa de tutela penal da ordem econômica diante do conceito de lesividade penal. Assim, perpassando-se pela visão clássica do conceito de lesividade como elemento necessário à constatação de ofensa ou séria ameaça de ofensa a um bem jurídico de caro interesse social, até sua apreensão como reveladora de uma transgressão ao ordenamento, ou lesão de dever, verificar-se-á sua ocorrência ou não na tipificação penal econômica. Tal revela-se elemento essencial para a reflexão da necessidade ou não de intervenção penal em específico ramo da atividade humana.

O próximo passo da investigação científico-jurídica, a ser desenvolvido no capítulo 3, é a confrontação da tutela penal da ordem econômica com a construção teorética dos delitos cumulativos, ou de acumulação. Dessa maneira, as noções de cumulatividade delitiva, o surgimento do conceito de cumulatividade, a apreensão de tais crimes como de perigo ou de resultado, assim como sua assimilação em face da lesividade penal, permitirão concluir pela capacidade ou incapacidade justificadora da tutela penal econômica consoante esse específico pensamento. 
A tutela penal da ordem econômica, conforme citado, representa paradigmático exemplo da característica da administrativização do Direito Penal, razão pela qual se impõe ao intérprete desta ciência uma acurada reflexão sobre isto, que se mostra algo típico do expansionismo legislativo-penal sem precedentes que vivenciamos. É o que norteará a pesquisa no capítulo 4. Ao ensejo, a chamada "Escola da Frankfurt" e o discurso de resistência à expansão do Direito Penal; a proposta de WINFRIED HASSEMER, qual seja, de um "Direito de Intervenção"; a proposta de JESÚS-MARÍA SILVA SÁNCHEZ, isto é, do Direito Penal dito de "duas velocidades", e a leitura administrativo-sancionadora no Brasil, que tem como expoentes MIGUEL REALE JÚNIOR, EDUARDO REALE FERRARI, HELENA REGINA LOBO DA COSTA e FÁBIO MEDINA OSÓRIO, serão os objetos de análise concernentes.

Por fim, no capítulo 5, intitulado "O Direito Penal e as infrações econômicas", pretende-se uma reflexão conclusiva do quanto adredemente investigado, permitindo-se apurar, a partir do discurso da criminalização difusa, a finalidade e eficiência jurídico-criminal na tutela econômica, confrontando esta com o princípio da ultima ratio e a busca por soluções alternativas. Para tanto, mister se fará estudar as formulações jurídicas mais adequadas à criminalidade econômica, propondo-se opções jurídicas como lege ferenda.

Uma vez que se pretende verificar os característicos da criminalização econômica contemporânea em face dos delineamentos da ciência penal, visando-se concluir pela legitimidade ou não do ramo jurídico-penal para a tutela da ordem econômica, a tese de doutoramento volta-se para a conclusão da pertinência ou não de tal gravosa intervenção jurídica neste ramo da atividade humana. 


\section{1 - ORDEM ECONÔMICA: CONCEITUAÇÃO E TENTATIVAS DE TUTELA PENAL}

SUMÁRIO: 1.1. Escorço histórico; 1.1.1. Primeira fase: casuísmo legislativo; 1.1.2. Segunda fase: proteção ao liberalismo; 1.1.3. Terceira fase: Estado do Bem-Estar Social; 1.1.4. Quarta fase: retração do papel do Estado; 1.1.5. A delinqüência econômica no Brasil; 1.1.6. Conclusão; 1.2. Pressupostos fundamentais; 1.2.1. A compreensão de Direito Penal Econômico; 1.2.1.1. A proteção de bens jurídicos como referência interpretativa material do Direito Penal; 1.3. Aproximação ao conceito de ordem econômica; 1.4. A confiança como elemento necessário para a reprodução e circulação da riqueza; 1.5. A experiência penal de garantia da ordem econômica na legislação brasileira atual; 1.6. Problemas dogmáticos do Direito Penal Econômico; 1.6.1. Crimes de perigo abstrato; 1.6.2. Tipos penais abertos; 1.6.3. Tipos penais de assessoriedade administrativa; 1.6.3.1.. Normas penais em branco; 1.6.4. Tipos omissivos e culposos 1.6.5. A incoerência do discurso legitimador dos fins da pena.

\subsection{Escorço histórico}

Não é recente a relação entre Direito Penal e economia, nem tampouco exclusividade do sistema capitalista, consoante se pode verificar por meio de uma referência histórica. Inicialmente remotos e esparsos, os casos de tal imbricamento vão assumir algum sentido maior de proteção econômica somente a partir do liberalismo e, num terceiro momento, característico do Estado do Bem-Estar Social, ostentar um fundamento ordenador com intuito simultâneo de tutela do modelo econômico estatal vigente e assecuração das políticas públicas deste modelo ${ }^{1}$. Por fim, constata-se uma fase última, que se afasta do Estado do Bem-Estar Social, de retração do papel estatal relativamente à economia.

\footnotetext{
1 Consoante os três momentos evolutivos da disciplina da concorrência propostos por PAULA A. FORGIONI, que se amoldam ao histórico da delinqüência econômica, a saber: a) uma primeira etapa, de busca por eliminação de distorções tópicas, por razões práticas; b) o momento subseqüente à Revolução Industrial, de correção de efeitos pontuais danosos, visando à manutenção do sistema e, por último, c) a fase de manutenção do sistema em conjunto com a implementação de políticas públicas, característica do Estado intervencionista. Cf. FORGIONI, Paula A. Os fundamentos do antitruste. São Paulo: RT, 2008, p. 32 e ss. Todavia, tendo em vista as mudanças de rumo das políticas econômicas fomentadas a partir dos Estados Unidos da América e Reino Unido na década de 80 do século passado, identificar-se-á uma quarta fase, de diminuição do papel do Estado na economia.
} 
Em face das peculiaridades da realidade brasileira, esta receberá menção apartada ao final do tópico.

\subsubsection{Primeira fase: casuísmo legislativo}

Inicialmente, os escassos exemplos colacionados pela doutrina não revelam na história jurídico-penal qualquer traço de continuidade ou maior ordenação, consubstanciando-se em proibições esporádicas ${ }^{2}$ e envoltas em peculiaridades de contextos sociais específicos.

Assim é que já na Grécia antiga, cujo sistema econômico era escravista, as moedas, conhecidas pelos gregos antes dos romanos $^{3}$, tinham sua falsificação punida com a pena de morte ${ }^{4}$. Estabelecendo a mesma sanção, no final do século III a.C., a legislação vigente na cidade de Átia vedava o abuso na comercialização de grãos, regulamentando-se estoques e limitando-se lucros 5 .

Ainda na Antigüidade ${ }^{6}$, em 18 a.C., durante o Alto Império, Roma teve promulgada por OTÁVIO AUGUSTO, da dinastia juliana, a Lex Julia de Annona, que estabelecia a pena de morte para a alta de preços e a violação de normas sobre importação

${ }^{2}$ BECHARA, Ana Elisa Liberatore S. Direito penal e economia: tutela penal da ordem econômica. Revista da Faculdade de Direito de São Bernardo do Campo, São Bernardo do Campo, ano 12, n 14, 2008, p. 64.

${ }^{3}$ A moeda cunhada, garantida pelo Estado, remonta ao século VII a.C. Cf. AQUINO, Rubim Santos Leão de; FRANCO, Denize de Azevedo \& LOPES, Oscar Guilherme Pahl Campos. História das sociedades: das comunidades primitivas às sociedades medievais. Rio de Janeiro: Ao Livro Técnico, 1980, p. 165.

${ }^{4}$ PRADO, Luiz Regis. Curso de direito penal brasileiro, volume 4: parte especial, arts. 289 a 359-H. São Paulo: Revista dos Tribunais, 2004, p. 60.

${ }^{5}$ Referido regramento, segundo KOTSIRIS, citado por FORGIONI, teria gerado o primeiro caso antitruste da história. Cf. FORGIONI, Paula A. Os fundamentos..., cit., pp. 35-37.

${ }^{6}$ Sobre o período, observa FERRARI: "Se de um lado é veraz que em Roma explícita foi a legislação quanto às normas de proibição da exploração da economia popular, punindo àqueles que monopolizavam atividades com figuras criminais tendentes a aumentar os preços de quaisquer utilidades, especialmente as destinadas ao uso essencial do povo, por outro, na Grécia, a proteção emergiu punindo os monopolistas que especulavam, armazenando quaisquer mercadorias que visassem forçar as altas dos preços de forma ilícita, a denotar que desde o seu nascedouro a seara penal econômica teve como finalidade limitar o comportamento social, preferindo-se, a nosso ver equivocadamente e por simbologia, a punição criminal do que a regulamentação administrativa”. FERRARI, Eduardo Reale. Legislação penal antitruste: direito penal econômico e sua concepção constitucional. In: REALE, Miguel; REALE JÚNIOR, Miguel \& FERRARI, Eduardo Reale. Experiências do direito. Campinas: Millennium, 2004, p. 254. No mesmo sentido na doutrina estrangeira, cf., por todos, TIEDEMANN, Klaus. Derecho penal económico: introducción y parte general. Lima: Grijley, 2009 , p. 78. 
e comércio de gêneros alimentícios ${ }^{7}$. Cuidava-se de um período de autoritarismo governamental que experimentou largo expansionismo comercial, fomentado pela política econômica de AUGUSTO, tendente a fixar o comércio como um traço de união do Império $^{8}$. Daí a caracterização de estreita regulação mercantil.

No período medieval, e.g., com viés punitivo, o Direito Canônico condenava à excomunhão aquele que praticasse a usura ${ }^{9}$, por considerar que dinheiro jamais poderia gerar dinheiro $^{10}$, sendo o tempo algo sagrado sobre o qual o homem não poderia criar uma taxação ${ }^{11}$. Não obstante, o desenvolvimento econômico da humanidade foi, pouco a pouco, temperando referido entendimento eclesiástico ${ }^{12}$.

Ainda acerca da época medieval, escreve KLAUS TIEDEMANN:

(...) A Idade Média traz consigo um conceito global de aplicação geral do falsum que reuniu, até a entrada da Idade Moderna e em um princípio sem um desenvolvimento de um tipo específico de estelionato (com o requisito de um dano patrimonial doloso), aspectos de proteção institucionais que se encontram, atualmente, no Direito penal acessório e em tipos especiais de fraude (falsificação de alimentos, moedas e pesos) $^{13}$.

Já no século XVIII, ao final da Idade Moderna, seguindo-se com o rol ilustrativo desta primeira fase, durante o reinado de MARIA TERESA, rainha da Hungria e

\footnotetext{
${ }^{7}$ DIAS, Jorge de Figueiredo \& ANDRADE, Manuel da Costa. Problemática geral das infrações contra a economia nacional. In: INSTITUTO DE DIREITO PENAL ECONÓMICO E EUROPEU - FACULDADE DE DIREITO DA UNIVERSIDADE DE COIMBRA. Direito penal económico e europeu: textos doutrinários. Coimbra: Coimbra, 1998, v. I, p. 324; SILVEIRA, Renato de Mello Jorge. Direito penal econômico como direito penal de perigo. São Paulo: Revista dos Tribunais, 2006, p. 20, nota 2, e p. 64; ROYSEN, Joyce. Histórico da criminalidade econômica. Revista Brasileira de Ciências Criminais, ano 11, $\mathrm{n}$. 42, jan.-mar. 2003, p. 192.

${ }^{8}$ AQUINO, Rubim Santos Leão de; FRANCO, Denize de Azevedo \& LOPES, Oscar Guilherme Pahl Campos. História das..., cit., pp. 244-245.

${ }^{9}$ Embora a usura já conhecesse vedação desde o Código de Hamurabi, há oscilação na história quanto a seu tratamento penal, conforme observou CARRARA. Apud AZEVEDO, Luiz Carlos de. Introdução à história do direito. São Paulo: Revista dos Tribunais, 2007, p. 164.

${ }^{10}$ GONZAGA, João Bernardino. A inquisição em seu mundo. São Paulo: Saraiva, 1993, p. 76, nota 4. Cf. ROBERTO LYRA: "Em toda evolução humana foram consagradas regras morais e religiosas, proclamando, desde Christo, a improdutividade das somas emprestadas. Nummus nummun non parit. São Tomás de Aquino sustentou, especialmente: 'Aquele que recebe, por empréstimo, uma quantia, torna-se proprietário dela e, como proprietário, não deve o pagamento de qualquer interesse"”. LYRA, Roberto. Crimes contra a economia popular: legislação - doutrina - jurisprudência. Rio de Janeiro: Livraria Jacinto, 1940, pp. 161-162.

${ }^{11}$ ROYSEN, Joyce. Histórico da..., cit., p. 192.

${ }^{12}$ GONZAGA, João Bernardino. A inquisição..., cit., p. 76, nota 4.

${ }^{13}$ TIEDEMANN, Klaus. Derecho penal..., cit., p. 78 (tradução livre).
} 
Boêmia, a exportação de cereais e frutas e a violação de normas sobre o fabrico de cerveja podiam ser punidas até com a morte ${ }^{14}$.

Até este momento histórico, conforme o próprio teor exemplificativo demonstra, por seu casuísmo, há na utilização do controle penal de assuntos de interesse da economia mero sentido de busca por correção de situações pontuais, sem sistematização ou uma lógica evolutiva, quer legislativa ou dogmática.

\subsubsection{Segunda fase: proteção ao liberalismo}

O fortalecimento do modelo econômico liberal do Estado-nação, por outro lado, vai despontar pela primeira vez na história uma razão sistêmica na regulação econômica, no geral, que possui consectários jurídico-penais ${ }^{15}$.

A matriz jurídica do Estado liberal pressupõe, notadamente, a estreita separação entre direito público e privado e o predomínio da autonomia da vontade privada na esfera econômica ${ }^{16}$. Como razão de ser de um modelo burguês que procurou superar as limitações à atividade econômica típicas das corporações de ofício ${ }^{17}$, não há maiores dificuldades de assimilação de tais características.

Neste influxo, a liberdade econômica num contexto de industrialização pressupõe o poder de conquistar novos consumidores e mercados. Ocorre que, neste ponto, verificou-se empiricamente que a livre atuação dos agentes econômicos culminou por gerar atos de concentração de capitais e monopólio ${ }^{18}$, os quais representam fatores contrários às características do sistema, devendo então ser rechaçados com vistas à própria manutenção deste $^{19}$.

\footnotetext{
14 DIAS, Jorge de Figueiredo \& ANDRADE, Manuel da Costa. Problemática geral..., cit., p. 324; SILVEIRA, Renato de Mello Jorge. Direito penal econômico..., cit., p. 20, nota 2.

${ }^{15}$ Nesta fase ao menos em termos legislativos.

${ }^{16}$ MONDACA, Luís S. Cabral de. Direito económico. Coimbra: Coimbra, 2007, p.18 e ss.

${ }^{17}$ FORGIONI, Paula A. Os fundamentos..., cit., pp. 57-58.

${ }^{18}$ BERSTEIN, Serge et all. História do século XX: volume I: 1900-1945: o fim do "mundo europeu”. Trad. Fernando Santos. São Paulo: Companhia Editora Nacional, 2007, p. 19.

${ }^{19}$ FORGIONI, Paula A. Os fundamentos..., cit., p. 64 e ss.; GRAU, Eros Roberto. A ordem econômica na constituição de 1988. São Paulo: Malheiros, 2007, p. 30 e passim; REALE, Miguel. Crise do capitalismo e
} 
Assim é que nesta conjuntura de pleno liberalismo econômico e poder político do Estado-nação consagrado pelo movimento codificador, e.g., os Códigos Penais da França (1810), Bélgica (1867) e Itália (1889) puniam criminalmente a especulação de mercadorias e títulos ${ }^{20}$.

Também neste período foi promulgado nos Estados Unidos da América o Sherman Act, primeira legislação antitruste daquele país. Datada de 1890, a lei recebeu a alcunha em homenagem a seu autor, senador republicano JOHN SHERMAN, cuidando-se de legislação que punia criminalmente tanto a pessoa física quanto a jurídica em razão de atos de monopólio ${ }^{21}$. PAULA A. FORGIONI considera que, dentro da linha evolutiva da disciplina da concorrência que propõe, o Sherman Act é o coroamento do segundo período identificado, pois consagra a concorrência “(...) como primordial para o sistema econômico, ao mesmo tempo em que exige uma atuação do Estado para eliminar as distorções que pode causar ao sistema" ${ }^{22}$.

Apesar de consagrador desta segunda fase evolutiva do tratamento penal da economia, em razão da falta de precisão quanto às condutas proibidas, no entanto, o Sherman Act foi substituído em 1914 pelo Clayton Antitrust $A c t^{23}$, seguido por sucessivas modificações ${ }^{24}$.

crise do estado. São Paulo: SENAC, 2000, p. 25. No mesmo sentido, entendendo a concentração econômica como uma falha estrutural, cf., e.g., NUSDEO, Fábio. Curso de economia: introdução ao direito econômico. São Paulo: Revista dos Tribunais, 2008, p. 149 e ss.

${ }^{20}$ DIAS, Jorge de Figueiredo \& ANDRADE, Manuel da Costa. Problemática geral..., cit., p. 324, nota 15; SILVEIRA, Renato de Mello Jorge. Direito penal econômico..., cit., p. 20, nota 2; ROYSEN, Joyce. Histórico da..., cit., p. 193; FERRARI, Eduardo Reale. Legislação penal..., cit., p. 254.

${ }^{21}$ Cf. UNITED STATES OF AMERICA GOVERNMENT. Sherman Anti-Trust Act (1890). Disponível em: $<$ http://www.ourdocuments.gov/doc.php?flash=true\&doc=51>. Acesso em 14/10/2009. Conforme RIGHI, "Segundo a opinião dominante, essa legislação foi conseqüência dos reclamos dos afetados pela crescente concentração de poder econômico em uma limitada quantidade de grupos econômicos, os quais o governo federal enfrentou para preservar a livre concorrência posta em perigo, o que é posto em questionamento por aqueles que, embora admitam a propensão monopolista de algumas companhias importantes, sustentam que foi um comportamento que durou pouco tempo e estava condenado ao fracasso". RIGHI, Esteban. Los delitos económicos. Buenos Aires: Ad-Hoc, 2000, p. 19 (tradução livre).

${ }^{22}$ FORGIONI, Paula A. Os fundamentos..., cit., pp. 71-72. Em sentido similar ao exposto, NUSDEO entende que desde a Antigüidade há normas esparsas de combate à concentração econômica, mas que assumem significação apenas ao final do século XIX, sendo o Sherman Act a lei de maior repercussão. NUSDEO, Fábio. Curso de..., cit., p. 151.

${ }^{23}$ FORGIONI, Paula A. Os fundamentos..., cit., pp. 80-81.

${ }^{24}$ RIGHI, Esteban. Los delitos..., cit., p. 20. 


\subsubsection{Terceira fase: Estado do Bem-Estar Social}

É apenas com o surgimento do intervencionismo do Estado do Bem-Estar Social - Welfare State -, decorrente das guerras mundiais do século XX e, no interregno destas, da crise de 1929, que se inicia uma sistemática centralização de regramento econômico, com vistas à proteção de economias nacionais fragilizadas, utilizando-se amplamente do Direito Penal para tanto ${ }^{25}$. A partir daí começam as preocupações dogmáticas sobre a relação entre este ramo jurídico e economia.

O início desta terceira fase de regulamentação da economia, qual seja, de intervencionismo econômico, relativamente ao qual se exaspera da utilização do Direito Penal para tanto, dá-se com a $1^{\mathrm{a}}$ Grande Guerra ${ }^{26}$. Os conflitos sociais a ela relacionados, a necessidade de direção e mobilização econômica para os esforços de guerra, em razão fundamentalmente da escassez de produtos e premência de controle de preços, forjaram uma radicalização do controle estatal da vida econômica no sentido de direção, conformação e defesa ${ }^{27}$. Ocorre então, nas palavras de FORGIONI, verdadeiro "surto de regulamentação estatal da atividade econômica"28.

Sobre o período, escrevem JORGE DE FIGUEIREDO DIAS e MANUEL DA COSTA ANDRADE:

As carências provocadas pela guerra levaram (em 1914) às leis que autorizaram o Bundesrat [Conselho Federal alemão] a tomar medidas consideradas necessárias em matéria económica e, em especial, no domínio dos preços (máximos). Seguiu-se a proliferação quase incontrolada de normas administrativas de direcção da vida económica que recorriam (abusivamente, por vezes) às sanções penais como garantia de eficácia e de prevenção. Só em

25 TIEDEMANN, Klaus. Poder económico y delito: introducción al derecho penal económico y de la empresa. Trad. Amelia M. Villegas. Barcelona: Ariel, 1985, p. 24; SILVEIRA, Renato de Mello Jorge. Direito penal econômico..., cit., p. 21 e p. 64; ROYSEN, Joyce. Histórico da..., cit., p. 193; BECHARA, Ana Elisa Liberatore S. Direito penal e..., cit., p. 64.

${ }^{26}$ Momento que marca o início da história do Direito Penal Econômico, segundo DIAS e ANDRADE. Cf. DIAS, Jorge de Figueiredo \& ANDRADE, Manuel da Costa. Problemática geral..., cit., p. 323. No mesmo sentido, e.g., BECHARA, Ana Elisa Liberatore S. Direito penal e..., cit., p. 64; SILVEIRA, Renato de Mello Jorge. Direito penal econômico..., cit., pp. 20-21 e 64.

${ }^{27}$ DIAS, Jorge de Figueiredo \& ANDRADE, Manuel da Costa. Problemática geral..., cit., p. 323.

${ }^{28}$ FORGIONI, Paula A. Os fundamentos..., cit., p. 83. 
matéria de luta contra formas especulativas (Kriegswuchergesetze) foram publicadas mais de quarenta mil disposições penais, que depois veriam a sua vigência prolongada para além do termo da guerra na forma de leis reguladoras de $\operatorname{preços}^{29}$.

A emblemática crise alemã levou, dessa forma, à edição da Constituição de Weimar (1919), marco do intervencionismo estatal na vida econômica com vistas à construção de um Estado de cunho social e que influenciou as elaboradas posteriormente ${ }^{30}$, como a Constituição brasileira de $1934^{31}$. O decreto contra o abuso do poder econômico, de 1923, é, conforme DIAS e ANDRADE, “(...) um caso típico da legislação (penal) económica da República de Weimar que historicamente surgiu como um estado econômico (Wirtschaftsstaat) - Tiedemann" ${ }^{32}$. O liberalismo do laissez-faire transmutava-se, assim, em uma tendência de um Estado preocupado com o bem-estar social ${ }^{33}$.

O movimento intervencionista estatal foi intensificado mais ainda em virtude da denominada Grande Depressão, ou crise de 1929, deflagrada nos Estados Unidos da América. $\mathrm{O}$ aumento da produtividade norte-americana, fruto da intensa industrialização, juntamente com medidas protecionistas, por um lado, não foi acompanhado de um aumento do poder aquisitivo da crescente população ${ }^{34}$, em razão dos baixos salários, e por outro, viu-se diante de uma crise econômica européia, decorrente da fragilização econômica produto da $1^{\text {a }}$ Grande Guerra ${ }^{35}$, fatores que reduziram drasticamente o mercado consumidor do parque industrial do país, gerando-se forte recessão.

\footnotetext{
${ }^{29}$ DIAS, Jorge de Figueiredo \& ANDRADE, Manuel da Costa. Problemática geral..., cit., pp. 324-325.

${ }^{30}$ Cf., e.g., BONAVIDES, Paulo. Curso de direito constitucional. São Paulo: Malheiros, 2009, p. 231; FABRI, Andréa Queiroz. Falhas de mercado: por uma nova visão do planejamento econômico. In: Direito econômico - evolução e institutos: obra em homenagem ao professor João Bosco Leopoldino da Fonseca. Rio de Janeiro: Forense, 2009, p. 55; BERCOVICI, Gilberto. Constituição econômica e desenvolvimento: uma leitura a partir da constituição de 1988. São Paulo: Malheiros, 2005, pp. 14-15. Este último autor observa com propriedade que a Constituição mexicana de 1917 foi a primeira a despontar num sentido de "constitucionalismo social" ou de afigurar-se como "Constituição Econômica", mas a mais célebre Carta Política representativa deste modelo foi a de Weimar. BERCOVICI, Gilberto. Constituição econômica..., cit. pp. 11-12.

${ }^{31}$ SILVA, José Afonso da. Curso de direito constitucional positivo. São Paulo: Malheiros, 1996, p. 83.

32 DIAS, Jorge de Figueiredo \& ANDRADE, Manuel da Costa. Problemática geral..., cit., p. 325 (destaques originais).

33 TIEDEMANN, Klaus. Poder económico..., cit., p, 71.

34 RUSSEL, Bertrand. História do pensamento ocidental: a aventura das idéias dos pré-socráticos a Wittgenstein. Trad. Laura Alves e Aurélio Rebello. Rio de Janeiro: Ediouro, 2002, p. 431.

${ }^{35}$ BERSTEIN, Serge et all. História do..., cit., p. 126.
} 
A queda das ações das empresas norte-americanas foi a conseqüência subsequiente que gerou desemprego e falências em larga escala ${ }^{36}$. O presidente eleito em 1932, FRANKLIN DELANO ROOSEVELT, influenciado pelas idéias do economista JOHN MAYNARD KEYNES, para fazer frente à crise, propôs uma política de grande intervencionismo estatal na economia, que ficou conhecida como New Deal.

Esta política foi implementada em três momentos: a) inicialmente, nos anos de 1933 e 1934, com a adoção de uma série de medidas, como a desvalorização da moeda americana (Gold Reserve Act), o controle mais rígido do sistema bancário (Banking Act), a amortização da dívida agrária e a destruição dos estoques agrícolas (Agricultural Adjustmanet Act) e a fixação de um novo paradigma na relação entre Estado e empresas (National Industrial Recovery Act); b) a seguir, tendo em vista a invalidação pela Suprema Corte norte-americana da maioria das medidas adotadas, uma reorientação levada a efeito em 1935, com maior combate ao desemprego, fortalecimento dos sindicatos e maior assistencialismo, e c) o momento final, em 1938, de aumento dos gastos públicos, de incremento de salários e controle mais rígido sobre as empresas ${ }^{37}$.

A iminência de uma nova guerra trouxe então no rearmamento um fator final de equacionamento da $\operatorname{crise}^{38}$, mas o fato é que estava consagrada uma postura de dirigismo estatal da vida econômica: "O Estado passa a dirigir o sistema, com o escopo de evitar as crises"39.

É exatamente a situação político-econômica norte-americana pós-crise de 1929 o substrato analítico da criminalidade no mundo dos negócios de EDWIN H. SUTHERLAND $^{40}$. Segundo sua teoria, da associação diferencial, a criminalidade não é

\footnotetext{
${ }^{36}$ BERSTEIN, Serge et all. História do..., cit., p. 258; GALBRAITH, John Kenneth. 1929 - o colapso da bolsa. Trad. Oswaldo Chiquetto. São Paulo: Livraria Pioneira, 1988, passim.

${ }^{37}$ BERSTEIN, Serge et all. História do..., cit., p. 276 e ss.; SHECAIRA, Sérgio Salomão. Criminologia. São Paulo: Revista dos Tribunais, 2004, p. 188 e ss.

${ }^{38}$ BERSTEIN, Serge et all. História do..., cit., p. 283.

${ }^{39}$ FORGIONI, Paula A. Os fundamentos..., cit., p. 84. No mesmo sentido, e.g., SHECAIRA, Sérgio Salomão. Criminologia..., cit., p. 191.

40 SUTHERLAND, Edwin H. El delito de cuello blanco: versión completa. Trad. Laura Belloqui. Montevideo-Buenos Aires: B de F, 2009, passim. Consoante SHECAIRA: “O mundo dos negócios possui uma firme organização no sentido de permitir a infração das normas que o regem, enquanto a sociedade não está organizada para impedir tal violação. Assim, as normas têm pouca importância no controle dos
} 
resultado de uma disfunção ou inadaptação de classes menos favorecidas, mas sim decorrente do aprendizado de uma conduta desviada e associação referente a ela, dentro do contexto comunicacional de um grupo social ${ }^{41}$. Para demonstração de sua teoria, SUTHERLAND detém-se num conjunto de pessoas de respeitabilidade e elevado estatuto social, relativamente ao qual não se esperaria que viessem a delinqüir: os "criminosos do colarinho branco"42. Iniciam-se assim as preocupações doutrinárias com a delinqüência econômica, consoante se analisará abaixo.

Em termos legislativos, pouco antes, durante e logo após o período da $2^{\mathrm{a}}$ Guerra Mundial, o dirigismo estatal da economia intensificou-se, tanto no regime nacionalsocialista alemão quanto nos países capitalistas e no bloco soviético ${ }^{43}$. Consoante lecionam DIAS e ANDRADE:

O caráter dirigista da economia do regime nacional-socialista e o seu posterior empenhamento na guerra fizeram surgir um Direito Penal Económico hipertrofiado, caracterizado pela natureza administrativa do seu processamento e pelo rigor das sanções. Muitas das normas deste direito mantiveram-se em vigor, outras foram perecendo por falta de aplicação, outras substituídas por nova legislação dispersa e avulsa a que a lei penal da economia de 1949 procurou dar alguma arrumação. É nesta lei que, pela primeira vez, se introduz a contraposição entre um direito penal (económico) e um direito de mera ordenação social, provocando o aparecimento da Ordnungswidrigkeitengesetz [Lei das contra-ordenações] de 1952. A lei penal da economia tem sofrido várias reformas importantes, a última das quais em $1975^{44}$.

A regulação estatal da economia só se fez aumentar a partir de então e as preocupações com a criminalidade econômica assumiram importante configuração na

comportamentos negociais, a menos que sejam suportadas por uma administração empenhada em impedir o comportamento ilegal. O que Roosevelt fez foi exatamente traduzir, mediante sua política intervencionista, o substrato legal para o controle dessas atividades chamadas ilícitas. O projeto do New Deal traz em seu bojo o fermento necessário para o crescimento do controle da atividade empresarial, denominada por Sutherland de crime do colarinho-branco, por meio de sua teoria da associação diferencial”. SHECAIRA, Sérgio Salomão. Criminologia..., cit., p. 193.

${ }^{41}$ SHECAIRA, Sérgio Salomão. Criminologia..., cit., p. 193 e ss.; SANTOS, Cláudia Maria Cruz. O crime de colarinho branco: (da origem do conceito e sua relevância criminológica à questão da desigualdade na administração da justiça penal). Coimbra: Coimbra, 2001, p. 43 e ss.; REALE JÚNIOR, Miguel. Instituições de direito penal - parte geral. Rio de Janeiro: Forense, 2009, p. 7.

${ }^{42}$ SHECAIRA, Sérgio Salomão. Criminologia ..., cit., p. 197.

${ }^{43}$ ROYSEN, Joyce. Histórico da..., cit., p. 194.

${ }^{44}$ DIAS, Jorge de Figueiredo \& ANDRADE, Manuel da Costa. Problemática geral..., cit., p. 325 (destaques originais). Sobre o tema, deste último autor, cf. também: ANDRADE, Manuel da Costa. Contributo para o conceito de contra-ordenação (a experiência alemã). In: INSTITUTO DE DIREITO PENAL ECONÓMICO E EUROPEU - FACULDADE DE DIREITO DA UNIVERSIDADE DE COIMBRA. Direito penal económico..., cit., V. I, p. 96 e ss. 
segunda metade do século XX, desvelando-se a radicalização da fórmula incriminadora. Todavia, os fundamentos e os delineamentos regulatórios deles resultantes passam a ostentar características diversas a partir do início dos anos 80 daquela centúria.

\subsubsection{Quarta fase: retração do papel do Estado}

Após um período de prosperidade econômica vivido com o fim da $2^{\mathrm{a}}$ Grande Guerra mundial $^{45}$, os Estados Unidos da América começam, nos anos 70, a sofrer com uma série de dificuldades econômicas e políticas deflagradas por diversos fatores, como a Guerra do Vietnã, os choques petrolíferos e retração econômica mundial deles decorrentes e o escândalo de Watergate ${ }^{46}$. Os modelos assistencialistas e de ações estatais com intuito de reaquecimento econômico, implementados pelos presidentes RICHARD NIXON, GERALD FORD e JIMMY CARTER, não contiveram a inflação, o aumento do deficit orçamentário e o desemprego, razões deflagradoras de significativa crise econômica nos Estados Unidos da América e, por via de conseqüência, na economia mundial.

É nesse contexto que assume a presidência norte-americana RONALD REAGAN, o qual, alinhado à primeira-ministra britânica MARGARETH THATCHER, adota uma política de redução da intervenção do Estado na economia ${ }^{47}$. Esta implicou a diminuição de impostos e de gastos públicos, perpassando por privatizações, redução de números de funcionários públicos e corte de medidas assistencialistas ${ }^{48}$.

Esta política de superação do Estado do Bem-Estar Social por um modelo de mínima intervenção estatal, sintetizada pela expressão "Consenso de Washington",49, consagrou no Direito Econômico uma postura de fixação de marcos regulatórios, ou seja, o Estado busca apenas gerenciar os atores econômicos com vistas à assecuração do modelo

${ }^{45}$ KENNEDY, Paul. Ascensão e queda das grandes potências: transformação econômica e conflito militar de 1500 a 2000. Rio de Janeiro: Campus, 1989, p. 394.

46 BERSTEIN, Serge et all. História do século XX: volume III: de 1973 aos dias atuais: a caminho da globalização e do século XXI. Trad. Fernando Santos. São Paulo: Companhia Editora Nacional, 2007, p. 163 e ss.

47 AGUILlAR, Fernando Herren. Direito econômico: do direito nacional ao direito supranacional. São Paulo: Atlas, 2009, p. 62; FABRI, Andréa Queiroz. Falhas de mercado..., cit. p. 57.

${ }^{48}$ BERSTEIN, Serge et all. História do século XX: volume III..., cit., p. 174 e ss.

49 AGUILLAR, Fernando Herren. Direito econômico..., cit., p. 68 e ss.; FABRI, Andréa Queiroz. Falhas de mercado..., cit. p. 58. 
vigente, sem interferir de forma mais significativa no mercado, que deve funcionar livremente ${ }^{50}$.

Isto não significou, contudo, uma diminuição do Direito Penal na seara econômica $^{51}$. Ao revés, neste cenário, de passagem da sociedade industrial para pósindustrial, em que novos riscos sociais ${ }^{52}$ foram revelados, o Direito Penal reafirmou-se como instrumento garantidor da política econômica estatal vigente e como instrumento de gerenciamento de riscos de uma sociedade altamente complexa ${ }^{53}$.

O grande poderio das empresas transnacionais numa economia globalizada possibilitou, por exemplo, fraudes com enormes repercussões, como se deu com os casos Enron e WorldCom ${ }^{54}$. Tais empresas norte-americanas, consoante foi divulgado nos anos de 2001 e 2002, protagonizaram dois rumorosos escândalos financeiros, envolvendo

${ }^{50}$ AGUILLAR, Fernando Herren. Direito econômico..., cit., p. 62; FABRI, Andréa Queiroz. Falhas de mercado..., cit. p. 58. Com visão crítica desta política de rompimento com o Estado do Bem-Estar Social, cf. GRAU, Eros Roberto. O direito posto e o direito pressuposto. São Paulo: Malheiros, 2005, p. 127 e ss.

${ }^{51}$ Assim como no geral, tendo havido, isto sim, seu alargamento. Para FRANCO, o declínio do Estado Social produziu não apenas a "criminalização da miséria", por conta do fomento à exclusão social, como também emrgiu um direito penal de emergência, com foco na sensação social de insegurança, cf. FRANCO, Alberto Silva. Na expectativa de um novo paradigma. In: ANDRADE, Manuel da Costa; ANTUNES, Maria João \& SOUSA, Susana Aires (orgs.). Estudos em homenagem ao prof. doutor Jorge de Figueiredo Dias. Coimbra: Coimbra, 2009, V. I, pp. 333-334.

52 BECHARA, Ana Elisa Liberatore S. Direito penal e..., cit., p. 64; SILVEIRA, Renato de Mello Jorge. Direito penal econômico..., cit., pp. 21-22 e 50 e ss.; SILVEIRA, Renato de Mello Jorge \& SALVADOR NETTO, Alamiro Velludo. Sarbanes-Oxley-Act e os vícios do direito penal globalizado. Revista Ultima Ratio, Rio de Janeiro, ano 1, nº 0, 2006, pp. 194-196; SILVEIRA, Renato de Mello Jorge \& SALVADOR NETTO, Alamiro Velludo. A tutela penal do mercado de capitais e o Sarbanes-Oxley-Act: novas considerações. In: RUIZ FILHO, Antonio \& SICA, Leonardo (Coordenação). Responsabilidade penal na atividade econômico-empresarial: doutrina e jurisprudência comentada. São Paulo: Quartier Latin, 2010, p. 373 e ss.

${ }^{53}$ Cf. BOTTINI: "Como se pode observar, a nova organização social e o paradoxo do risco são responsáveis por alterações significativas no direito penal. A legislação criminal sofre as primeiras influências da insegurança social perante as novas tecnologias e altera seus dispositivos de acordo com o sentido das demandas pela maior ou menor restrição dos riscos". BOTTINI, Pierpaolo Cruz. Crimes de perigo abstrato e princípio da precaução na sociedade de risco. São Paulo: Revista dos Tribunais, 2007, p. 109.

${ }^{54}$ SILVEIRA, Renato de Mello Jorge. Direito penal econômico..., cit., p. 21; SILVEIRA, Renato de Mello Jorge \& SALVADOR NETTO, Alamiro Velludo. Sarbanes-Oxley-Act e..., cit., p. 196; SILVEIRA, Renato de Mello Jorge \& SALVADOR NETTO, Alamiro Velludo. A tutela penal..., cit., p. 375; ROYSEN, Joyce. Histórico da..., cit., p. 196 e ss.; BECHARA, Ana Elisa Liberatore S. Direito penal e..., cit., p. 64. Os três primeiros textos referem-se, ainda, ao similar escândalo financeiro envolvendo a empresa italiana Parmalat. Como este somente eclodiu no ano de 2003, após a emblemática reforma legislativa norte-americana a seguir citada, não se fez menção a ele no texto. 
bilhões de dólares de prejuízos, em razão de fraudes contábeis encetadas por seus executivos ${ }^{55}$.

Desta maneira, por conta destes dois casos, com escopo de tutelar mais eficientemente o mercado financeiro, editou-se em julho de 2002 nos Estados Unidos da América o Sarbanes-Oxley Act ${ }^{56}$, legislação que alterou o United States Code de modo a recrudescer o tratamento penal do tema ${ }^{57}$. Em essência, consagrando o valor da confiabilidade nas relações negociais ${ }^{58}$, esta lei impõe a obrigatoriedade, por parte dos administradores e diretores financeiros das empresas, de inserção em suas declarações periódicas, semestrais e anuais, aos acionistas, de compromisso de retidão das informações prestadas, sob pena de cometimento de crime de falsidade punido com até 20 anos de reclusão ${ }^{59}$, independentemente de comprovação de qualquer lesividade. Sobre este diploma, contundentes as críticas de RENATO DE MELLO JORGE SILVEIRA e ALAMIRO VELLUDO SALVADOR NETTO:

\begin{abstract}
Dispondo, por igual, de aspectos penais, mostra-se ela, além de contornos simbólicos, dotada de absurdos sintomáticos. Rompe com princípios maiores como de extraterritorialidade; de garantias penais e processuais, de culpabilidade e de proporcionalidade. A chamada Sarbanes-Oxley Act, nesse passo, mostra-se como sendo instrumento bastante hábil para o retrato do caos criminalizante, curiosamente, contudo, defendido por setores que sustentam a defesa da estabilidade dos mercados, acima de tudo ${ }^{60}$.
\end{abstract}

Há dúvidas quanto à manutenção desse modelo gerencialista estatal após a crise de 2008, deflagrada a partir de uma forte retração do crédito nos Estados Unidos da América (chamada de "bolha do crédito") por conta do colapso do sistema hipotecário, que

\footnotetext{
${ }^{55}$ ROYSEN, Joyce. Histórico da..., cit., p. 196 e ss.

56 A alcunha legislativa decorre da composição do patronímico dos parlamentares subscritores do diploma legal: senador democrata PAUL SARBANES e deputado republicano MICHAEL OXLEY.

${ }^{57}$ O Sarbanes-Oxley Act tem sido considerado como o mais radical meio de controle do mercado desde a crise de 1929. Neste sentido, por exemplo: ROYSEN, Joyce. Histórico da..., cit., p. 203; SILVEIRA, Renato de Mello Jorge \& SALVADOR NETTO, Alamiro Velludo. Sarbanes-Oxley-Act e..., cit., p. 201; SILVEIRA, Renato de Mello Jorge \& SALVADOR NETTO, Alamiro Velludo. A tutela penal..., cit., p. 385.

${ }^{58} \mathrm{E}$, desta maneira, consagrando a postura estatal gerencialista.

${ }^{59}$ SILVEIRA, Renato de Mello Jorge \& SALVADOR NETTO, Alamiro Velludo. Sarbanes-Oxley-Act e..., cit., p. 201; SILVEIRA, Renato de Mello Jorge \& SALVADOR NETTO, Alamiro Velludo. A tutela penal..., cit., p. 388.

${ }^{60}$ SILVEIRA, Renato de Mello Jorge \& SALVADOR NETTO, Alamiro Velludo. Sarbanes-Oxley-Act e..., cit., pp. 193-194. No mesmo sentido, cf. SILVEIRA, Renato de Mello Jorge \& SALVADOR NETTO, Alamiro Velludo. A tutela penal..., cit., p. 372.
} 
ensejou relevante intervenção estatal na economia ${ }^{61}$. Esta se deu na forma de liberação de crédito pelos governos ao redor do mundo, aumento de regulação normativa e operacional $^{62}$, bem como pontual compra de ações de grandes empresas transnacionais pelo governo norte-americano.

É provável ainda ser cedo para se chegar a uma sólida conclusão a respeito, mas o socorro financeiro estatal e o aumento da regulação, na forma que se deram, não parecem ter desfigurado a política gerencialista a ponto de demonstrar um retorno ao modelo do Estado do Bem-Estar Social ${ }^{63}$. De qualquer forma, a tendência expansionista jurídico-penal em matéria econômica permanece.

\subsubsection{A delinqüência econômica no Brasil}

Até as primeiras décadas do século XX, é pouco significativa a relação entre Direito Penal e economia no Brasil. Embora possa haver maior interesse histórico para o Direito Econômico na análise do período colonial, que apresentou a fase de simples exploração econômica e, posteriormente, de início de orientação econômica, esta com a vinda da Corte portuguesa para o Brasil, em $1808^{64}$, em termos jurídico-penais à época, nas Ordenações Filipinas ${ }^{65}$, e.g., no Título XII do Livro V, punia-se a falsificação de moedas, e, no Título LVI do mesmo Livro, as fraudes empreendidas por ourives ${ }^{66}$.

\footnotetext{
${ }^{61}$ AGUILLAR, Fernando Herren. Direito econômico..., cit., p. 77-79; FRANCO, Alberto Silva. Globalização e os riscos ao sistema penal brasileiro. AIDP - Publicação Oficial do Grupo Brasileiro da Associação Internacional de Direito Penal, ano 5, n. 5, 2009, p. 5; FRANCO, Alberto Silva. Na expectativa..., cit., p. 338 e ss.

${ }^{62}$ AGUILLAR, Fernando Herren. Direito econômico..., cit., p. 77; FRANCO, Alberto Silva. Globalização e os riscos..., cit., pp. 5-6.

${ }^{63}$ Em sentido oposto, entendendo que se caminha para a reconstrução de um Estado social, cf. FRANCO, Alberto Silva. Globalização e os riscos..., cit., p. 6. Posteriormente, o autor temperou em certa medida seu posicionamento, reconhecendo a indefinição da construção de um novo paradigma, o qual, segundo entende, deve perpassar pela reconstrução do Estado social, cf. FRANCO, Alberto Silva. Na expectativa..., cit., pp. 344-345.

${ }^{64}$ Cf. FORGIONI, Paula A. Os fundamentos..., cit., pp. 94-104.

${ }^{65}$ Primeira legislação efetivamente vigente e aplicável por mais de dois séculos em terras brasileiras. Cf., e.g., PIERANGELI, José Henrique. Códigos penais do Brasil: evolução histórica. São Paulo: Revista dos Tribunais, 2001, p. 55 e pp. 60-61; GARCIA, Basileu. Instituições de direito penal. São Paulo: Saraiva, 2008 , v. I, tomo I, p. 175 e ss.

${ }^{66}$ Do mesmo modo pouco sistemático, casuístico, escassos alvarás do príncipe regente, como o de 14 de agosto de 1809, que procurava reforçar a repressão ao contrabando, ou o de 12 de fevereiro de 1810, que cuidava de extravio de ouro, tiveram algum interesse jurídico-penal.
} 
No Brasil independente observa-se que o Código Criminal do Império (1830) e o Código Penal Republicano (1890) puniam, por exemplo, a falsificação de moedas ${ }^{67}$ e a falência $^{68}$ (chamada "banca-rota" naquele) $)^{69}$. Todavia, possivelmente em face da industrialização tardia nacional ${ }^{70}$, não se notam traços reveladores de uma identificação com a fase correspondente no Direito anglo-saxão ou europeu continental da mesma época, qual seja, de despontamento de normas tendentes a uma proteção do modelo econômico liberal $^{71}$.

Aliás, neste influxo, o país parece ter saltado de uma fase meramente casuística para, a partir do final dos anos de 1930, seguir a tendência de alargamento da tutela penal da economia ${ }^{72}$, mas inicialmente de modo claudicante e sempre de forma peculiar, pouco sistemática e de modo a se proteger os mais diversos interesses ${ }^{73}$.

Para corroborar tal entendimento observa-se que, embora a Constituição de 1934 tenha sido efetivamente influenciada pelo fundamento do Estado intervencionista ${ }^{74}$, teve curta vigência e, no que diz respeito ao ordenamento penal, não se viu acompanhada de um fenômeno de ampla tipificação de cunho econômico. Inclusive, na maior parte dos anos de 1930, momento de efervescência do Estado do Bem-Estar Social alhures, com ampla criminalização econômica, o Brasil ${ }^{75}$ deteve com algum interesse penal econômico

\footnotetext{
${ }^{67}$ Artigos 173 a 176 do Código Criminal do Império do Brasil e 239 a 244 do Código Penal de 1890.

${ }^{68}$ Artigo 263 do Código Criminal de 1830 e artigos 336 e 337 do Código Penal de 1890.

${ }^{69}$ ROYSEN, Joyce. Histórico da..., cit., p. 193.

70 Apontando as razões do atraso, cf. PRADO JÚNIOR, Caio. História econômica do Brasil. São Paulo: Brasiliense, 1970, p. 257 e ss.

${ }^{71}$ Em sentido similar relativamente ao específico ramo do Direito Concorrencial, escreve FORGIONI: “(...) os ventos do liberalismo, no Brasil, fizeram-se sentir de forma muito particular, e a disciplina da atividade dos agentes econômicos no mercado, buscando a tutela da livre concorrência e a repressão ao abuso do poder econômico, assume ainda hoje um caráter bastante típico (e que decorre, diretamente, de nossa evolução histórica), diverso dos demais ordenamentos em que habitualmente o legislador busca sua inspiração". FORGIONI, Paula A. Os fundamentos..., cit., p. 94.

72 "Quem fixar o conjunto da evolução legislativa no Brasil há de reconhecer, a partir de 1930, o crescente primado do interesse coletivo, no mecanismo do Estado”. LYRA, Roberto. Crimes contra..., cit., p. 91.

${ }^{73}$ No mesmo sentido quanto às normas antitruste, cf. FORGIONI, Paula A. Os fundamentos..., cit., p. 125.

${ }^{74}$ Seu artigo 115 fixava: "A ordem econômica deve ser organizada conforme os princípios da justiça e as necessidades da vida nacional, de modo que possibilite a todos existência digna. Dentro desses limites, é garantida a liberdade econômica”.

${ }^{75}$ Embora FORGIONI identifique que na década de 30 do século XX o Estado brasileiro tenha intensificado sua atuação sobre e no domínio econômico, o fato é que tal não se deu por meio do Direito Penal. FORGIONI, Paula A. Os fundamentos..., cit., p. 109.
} 
apenas os crimes contra a liberdade de trabalho ${ }^{76}$ e a falsificação de moedas ${ }^{77}$, previstos na Consolidação das Leis Penais, e a repressão ao delito de usura, pelo Decreto $n^{\circ} 22.626$, de $1933^{78}$

É somente a partir do Decreto-lei 869/38 que a relação entre Direito Penal e economia começa a ganhar alguma importância no país. Decorrente de uma regulamentação do artigo 141 da Constituição de $1937^{79}$, que adotava dentre seus princípios a proteção à economia popular, a legislação varguista procurava coibir pontuais abusos do poder econômico ${ }^{80}$, tendo em vista os interesses do consumidor ${ }^{81}$.

Com o Código de 1940, cuja edição não revogou o Decreto-lei 869/38, há novamente apenas o imbricamento esporádico entre Direito Penal e economia, como com os exemplos dos crimes de moeda falsa e contrabando.

${ }^{76}$ Artigo 204 da Consolidação das Leis Penais.

${ }^{77}$ Artigos 239 a 244 da Consolidação das Leis Penais.

${ }^{78}$ FERRARI considera citado diploma como a primeira manifestação penal econômica no Brasil, cf. FERRARI, Eduardo Reale. Legislação penal..., cit., p. 255.

79 Cujo teor era o seguinte: "A lei fomentará a economia popular, assegurando-lhe garantias especiais. Os crimes contra a economia popular são equiparados aos crimes contra o Estado, devendo a lei cominar-lhes penas graves e prescrever-lhes processos e julgamentos adequados à sua pronta e segura punição".

80 Comentando o Decreto-lei 869/38, escreveu NELSON HUNGRIA em 1939: "Na pureza de seus postulados, o liberalismo econômico está, porém, na atualidade, geralmente desacreditado. É uma doutrina que a experiência dos povos demonstrou errônea, anárquica, contraproducente. Ela abstrai que, no livre jogo de suas competições e antagonismos, os individuos entram com desiguais elementos de ação, resultando daí que os mais fracos acabam sobrepujados pelos mais fortes, e como estes nem sempre são os mais dignos e honestos, senão os mais velhacos, prepotentes e egoistas, a sua supremacia é alcançada com fatal detrimento do interesse social. O regime de livre e desvigiada iniciativa popular favorece o enriquecimento de poucos em prejuizo da grande massa da população. A fraude, a violência e o abuso são armas preferidas e decisivas onde as atividades individuais em contraste não deparam um força coativa de equilibrio ou justa medida. Deixar os individuos ao seu puro arbítrio é implantar a lei da selva (...)". HUNGRIA, Nelson. Dos crimes contra a economia popular e das vendas a prestações com reserva de dominio. Rio de Janeiro: Livraria Jacintho, 1939, pp. 5-6. Poucas semanas antes da edição desta obra o mesmo trecho foi publicado pelo autor em HUNGRIA, Nelson. Os crimes contra a economia popular e o intervencionismo do Estado. Revista Forense, Rio de Janeiro, jul.1939, p. 45.

${ }^{81}$ LYRA, Roberto. Crimes contra..., cit., p. 93; FORGIONI, Paula A. Os fundamentos..., cit., p.114. Embora seja esse mesmo o sentido, à época não se utilizava comumente da palavra "consumidor" e sim, geralmente, de "povo" ou da expressão "economia do povo", como o fazia, por exemplo, HUNGRIA, Nelson. Dos crimes..., cit., p. 14 e passim. Sobre o tema, FORGIONI observa ainda que o Estado procurou com referido diploma não a função de condução do sistema, mas apenas a correção de eventuais disfunções. Cf. FORGIONI, Paula A. Os fundamentos..., cit., p.116. 
A seguir, revelando falta de sistematização quanto ao tema da repressão ao abuso do poder econômico ${ }^{82}$, o Decreto-lei 7.666/45, de cunho exclusivamente administrativo, procurou coibir atos contrários aos interesses econômicos nacionais, definidos pelo diploma, e criou a Comissão Administrativa de Defesa Econômica. Esta norma, todavia, teve poucos meses de vigência, tendo sido revogada com a queda de GETÚLIO VARGAS ${ }^{83}$.

Posteriormente, procurando regulamentar o artigo 148 da Constituição de $1946^{84}$, que previu expressamente a repressão ao abuso do poder econômico ${ }^{85}$, a Lei $1.521 / 51^{86}$, consagrou a utilização do Direito Penal na seara econômica, revelando escopo antitruste $^{87}$ e de tutela do consumidor. Este o duplo aspecto que deflui da análise das discussões legislativas quando da elaboração da lei, oportunidade em que se refere inclusive a consumidor ${ }^{88}$.

Após isso, apenas a partir da década de 60, fundamentalmente no período de autoritarismo político posterior à Constituição de 1967, foram editadas leis de cunho penal econômico, sob questionáveis argumentos de necessidade de combate à inflação e de valorização monetária, sem ordenação e com pouca aplicabilidade prática ${ }^{89}$. A tendência

${ }^{82}$ FORGIONI, Paula A. Os fundamentos..., cit., p.120.

${ }^{83}$ FORGIONI, Paula A. Os fundamentos..., cit., pp. 122-123.

${ }^{84} \mathrm{O}$ qual estatuía: “A lei reprimirá toda e qualquer forma de abuso do poder econômico, inclusive as uniões ou agrupamentos de empresas individuais ou sociais, seja qual for a sua natureza, que tenham por fim dominar os mercados nacionais, eliminar a concorrência e aumentar arbitrariamente os lucros".

${ }^{85}$ Sobre o texto constitucional, escreve REALE JÚNIOR: "Graças à insistência do Deputado Agamenon Magalhães, a Constituição de 1946 estatuiu, no art. 148, que caberia, como um dos objetivos à consecução de uma ordem econômica justa, reprimir-se o abuso do poder econômico (...)”. REALE JÚNIOR, Miguel. Despenalização no direito penal econômico: uma terceira via entre o crime e a infração administrativa? Revista Brasileira de Ciências Criminais, São Paulo, n. 28, 1999, p. 116.

86 "Com a adoção do Estado Democrático de Direito em 1946, dispositivos foram surgindo consolidando a existência de ponderadas infrações contra a Economia Popular, editando-se, em 26 de dezembro de 1951, a primeira lei penal ordinária dispondo integralmente acerca de temática da ordem econômica, entrando em vigência em 26 de fevereiro de 1952, hoje a conhecida Lei n. 1521/51”. FERRARI, Eduardo Reale. Legislação penal..., cit., pp. 256-257.

${ }^{87}$ FORGIONI, Paula A. Os fundamentos..., cit., p. 125.

${ }^{88}$ Cf. SOUSA NETO. Júri de economia popular: comentários à Lei no 1.521 , de 26 de dezembro de 1951. Rio de Janeiro: Forense, 1952, passim. Sintetizando as razões constitucionais e históricas desta lei, escreveu este autor: “(...) O Estado intervém para regular o uso da propriedade, condicionando-o ao bem estar social; para distribuir, com igualdade de oportunidade para todos; e, finalmente, para castigar o abuso e a exploração, proibindo o domínio dos mercados, a eliminação da concorrência e o aumento arbitrário de lucros". SOUSA NETO. Júri de..., cit., p. 9.

${ }^{89}$ Neste sentido, cf. FERRARI, Eduardo Reale. Legislação penal..., cit., p. 257. 
expansiva, ainda sem sistematização e de forma pouco técnica, radicaliza-se nos anos 90 do século passado.

Em que pese a edição do Código Penal de $1940^{90}$, reformado em sua Parte Geral em 1984, no que diz respeito à criminalização econômica, a via escolhida pelo legislador nacional foi preponderantemente a do tratamento do tema em legislação extravagante, relativamente à qual se faz menção, em termos genéricos, dentre outros, aos seguintes significativos diplomas de interesse: Lei 1.521/51 (crimes contra a economia popular), Lei 4.729/65 (crimes de sonegação fiscal), Lei 7.492/86 (crimes contra o sistema financeiro nacional), Lei 8.078/90 (Código de Defesa do Consumidor), Lei 8.137/90 (crimes contra a ordem tributária, econômica e contra as relações de consumo), Lei 8.176/91 (modalidades de crimes contra a ordem econômica), Lei 8.666/93 (Lei de Licitações), 9.615/98 (crimes ambientais), Lei 9.613/98 (crimes de lavagem de dinheiro), Lei Complementar 105/2001 (delitos contra o sigilo das operações de instituições financeiras) e Lei 10.303/2001 (crimes contra o mercado de capitais).

De se notar que a significativa maioria dos diplomas legais referentes ao temário foi editada após a vigência da Constituição da República Federativa do Brasil de 1988, devendo, desse modo, haver uma particular referência a respeito.

De caráter analítico, ou em outras palavras, extremamente detalhista ${ }^{91}$, inclusive nos inúmeros dispositivos que não se afiguram como normas essencialmente

${ }^{90}$ Com pouco interesse penal econômico, como asseverado.

${ }^{91}$ Identificando como uma das principais razões disso a falta de adoção de um projeto prévio à época da Constituinte, que teve seus trabalhos pulverizados em múltiplas subcomissões, cf. BASTOS, Celso Ribeiro. Curso de direito constitucional. São Paulo: Malheiros, 2010, p. 213. Especificamente sobre o texto editado atinente à ordem econômica e financeira, GASTÃO ALVES TOLEDO acrescenta: "A ordem econômica constitucional retrata as incertezas e perplexidades reinantes durante os trabalhos da constituinte de 1987/88. Reunida em período marcado pelo clima do ressurgimento político, após o término do regime militar, teve como pano de fundo, na esfera econômica, um processo inflacionário crônico, o descalabro fiscal, a moratória da dívida externa que só acarretou malefícios e o fracasso de um plano econômico (plano cruzado) que em nada contribuiu para conduzir a economia aos trilhos da normalidade. Ao contrário, exacerbou mais os ânimos já exaltados pela oportunidade de modificar a estrutura jurídica do país, dotando-o de instituições que o tornassem menos vulnerável às incertezas econômicas e apto a se autodeterminar no âmbito da política externa”. TOLEDO, Gastão Alves de. Ordem econômica e financeira. In: MARTINS, Ives Gandra da Silva; MENDES, Gilmar Ferreira; NASCIMENTO, Carlos Valder do (Coords.). Tratado de direito constitucional. São Paulo: Saraiva, 2010, V. II, p. 307. 
constitucionais $^{92}$, a Carta Política ora em vigor no Brasil, apesar de adotar o regime da livre empresa ${ }^{93}$, por meio do qual é livre o exercício de qualquer atividade econômica, independentemente de autorização estatal, salvo casos excepcionais expressos em lei, mostra-se dirigente em termos econômicos ${ }^{94}$, pois "é certo que a livre iniciativa cede passo à intervenção do Estado em alguns pontos"95.

Neste influxo, ao Estado, enquanto agente normativo e regulador da economia, é dada a fiscalização, o incentivo e o planejamento da atividade econômica em nosso país (artigo 174 da Lei Maior), além de, em certos casos, explorar diretamente essa atividade (artigo 173 da Lei Maior) ${ }^{96}$.

Os pilares fundamentais da atividade econômica nacional estão elencados no caput do artigo 170 da Carta de 1988: I - soberania nacional; II - propriedade privada; III - função social da propriedade; IV - livre iniciativa; V - defesa do consumidor; VI defesa do meio ambiente, inclusive mediante tratamento diferenciado conforme o impacto ambiental dos produtos e serviços e de seus processos de elaboração e prestação; VII redução das desigualdades regionais e sociais; VIII - busca do pleno emprego e IX tratamento favorecido para as empresas de pequeno porte constituídas sob as leis brasileiras e que tenham sua sede e administração no País. Em nome desses princípios gerais $^{97}$, que para GILBERTO BERCOVICI seriam um plano de transformação da

\footnotetext{
92 BONAVIDES denomina tais Constituições como prolixas: "As Constituições prolixas, cada vez mais numerosas, são em geral aquelas que trazem matéria por sua natureza alheia ao direito constitucional propriamente dito. Trata-se ora de minúcias de regulamentação, que melhor caberiam em leis complementares, ora de regras ou preceitos até então reputados pertencentes ao campo da legislação ordinária e não do Direito Constitucional, em cuja esfera entram apenas formalmente, por arbítrio do legislador constituinte, para auferir garantias que só a Constituição proporciona em toda a amplitude". BONAVIDES, Paulo. Curso de..., cit., p. 91.

${ }^{93}$ BASTOS, Celso Ribeiro. Curso de..., cit., p. 632.

${ }^{94}$ CANOTILHO, José Joaquim Gomes. Constituição dirigente e vinculação do legislador: contributo para a compreensão das normas constitucionais programáticas. Coimbra: Coimbra, 2001, pp. 12, 14, 18-24, passim; BERCOVICI, Gilberto. A Problemática da Constituição Dirigente: Algumas Considerações sobre o Caso Brasileiro. Revista de Informação Legislativa, Brasília, Senado Federal, n. 142, abr.-jun. 1999, pp. 35-51; FERRARI, Eduardo Reale. Legislação penal..., cit., p. 257.

${ }^{95}$ BASTOS, Celso Ribeiro. Curso de..., cit., p. 632.

${ }^{96}$ BASTOS, Celso Ribeiro. Curso de..., cit., pp. 632-633.

${ }^{97}$ EROS GRAU acrescenta outras diretivas constitucionais no bojo da ordem econômica, tais como a dignidade da pessoa humana e a construção de uma sociedade livre, justa e solidária. GRAU, Eros Roberto. A ordem..., cit., p. 216.
} 
sociedade brasileira $^{98}$, estabelece-se, dentre outras minúcias, a repressão ao abuso do poder econômico $^{99}$ que vise à dominação dos mercados, à eliminação da concorrência e ao aumento arbitrário dos lucros ${ }^{100}$.

Esse último aspecto, de repressão ao abuso do poder econômico, em consonância com os pilares fundamentais da atividade econômica insculpidos pelo constituinte de 1988, representa, assim, o necessário sentido interpretativo das normas infraconstitucionais com aspectos econômicos. Tratando dos desafios hermenêuticos impostos pela disciplina da ordem econômica e financeira da Carta de 1988, TOLEDO observa que:

(...) a ordem econômica constitucional, em sentido amplo, abriga princípios e diretrizes capazes de dar supedâneo a todas as providências legislativas ou administrativas necessárias ao enfrentamento de circunstâncias que ponham em risco o desempenho da economia $(. . .)^{101}$.

Desse modo, para além de uma série de normas de Direito Econômico propriamente dito, ou Administrativo, Comercial e Civil, estes nas hipóteses em que apresentarem aspectos econômicos, também é similar a compreensão hermenêutica a ser empregada na interpretação da legislação penal econômica produzida após a Carta ora em vigor $^{102}$.

98 BERCOVICI, Gilberto. Desigualdades regionais, estado e constituição. São Paulo: Max Limonad, 2003, pp. 312-315.

${ }^{99}$ Sobre o temário, pondera BASTOS: "Os modelos clássicos de economia de mercado mostram-se ao longo do tempo inaptos para estabelecerem um mercado em perfeito equilíbrio. $\mathrm{Na}$ verdade, o perfeito modelo proposto por Adam Smith, revela-se utópico. A competição na prática não é a mesma competição puramente teorizada. Desse relativismo nasce a necessidade imperiosa de o Estado cuidar destas relações econômicas. Nesta tarefa, estabelecem-se as medidas, dentro de preceitos máximos de direito, que equilibrem a livre iniciativa e a livre concorrência legítimas, com os abusos por parte de poderosas forças produtivas, que nada mais fazem do que excederem os limites de seus direitos, atentando contra princípios morais informativos da ordem econômica livre”. BASTOS, Celso Ribeiro. Curso de..., cit., p. 644.

${ }^{100}$ Artigo $170, \S 4^{\circ}$, da Constituição de 1988. O parágrafo seguinte deste mesmo dispositivo seria aquele que, consoante parte da doutrina, fixaria a responsabilidade penal da pessoa jurídica em crimes contra a ordem econômica e financeira e contra a economia popular.

101 TOLEDO, Gastão Alves de. Ordem econômica..., cit., p. 314.

102 O tema será desenvolvido abaixo, item "1.3", a partir da noção do bem jurídico ordem econômica. Mas desde já se observa que a ratio essendi da norma penal econômica legítima somente pode ser aquela que vise, em conjunto com as demais normas jurídicas atinentes à matéria, a proteção dos pilares fundamentais da atividade econômica nacional, em todo seu conjunto. Daí porque, por exemplo, o sentido não pode ser tãosomente o de singular defesa da propriedade (caso, e.g., dos crimes contra o patrimônio), mas, além desta, da defesa do consumidor e da livre iniciativa, dentre outros aspectos. 
Há que se observar, nesse ponto, que parte da doutrina, conforme observa no Brasil JANAINA CONCEIÇÃO PASCHOAL ${ }^{103}$, supõe haver até a necessidade de criminalização de condutas em decorrência do texto constitucional ${ }^{104}$, em nome de interesses ali tutelados ${ }^{105}$. Nesse sentido, a legislação extravagante de jaez penal econômico poderia ser entendida, ainda que indiretamente com escora nos $\S \S 4^{\circ}$ e $5^{\circ}$ do artigo 173 da Lei Maior, como em atendimento ao citado postulado ${ }^{106}$.

Todavia, em consonância com o já manifestado alhures ${ }^{107}$, e de acordo com o pensamento, na doutrina nacional, de PASCHOAL ${ }^{108}$ e de REALE JÚNIOR ${ }^{109}$, não se adota referido posicionamento. A suposta obrigatoriedade constitucional de criminalização de condutas é de todo incompatível com a configuração de um Estado Democrático de Direito, o qual possui, por sua própria essência, a liberdade dos cidadãos como regra e o mais grave meio de seu cerceamento, que é o regramento penal, como exceção, a ser utilizado apenas para coibir os mais graves ataques aos mais caros valores comunitários e

103 PASCHOAL, Janaina Conceição. Constituição, criminalização e direito penal mínimo. São Paulo: Revista dos Tribunais, 2003, p. 69 e ss., passim.

${ }^{104}$ Exemplo deste posicionamento tem-se, na literatura pátria, com ANTONIO CARLOS DA PONTE, que afirma: "Os mandados de criminalização indicam matérias sobre as quais o legislador ordinário não tem a faculdade de legislar, mas a obrigatoriedade de tratar, protegendo determinados bens ou interesses de forma adequada e, dentro do possível, integral". PONTE, Antonio Carlos da. Crimes eleitorais. São Paulo: Saraiva, 2008 , p. 152.

105 Segundo a autora, tal entendimento decorre da perspectiva que se tem do Direito Penal em face da Constituição: "Com efeito, quando deixa de ser limite, transformando-se em fundamento, a Constituição passa a ser tomada como propulsora do Direito Penal, permitindo-se que qualquer situação de 'emergência', ou de aparente 'emergência', possa ensejar questionamentos relativos ao descumprimento de uma indicação, ou determinação constitucional de criminalização. Essa modificação de prisma faz com que, ante a Constituição, a criminalização de uma determinada conduta deixe de ser vista apenas como possível, passando a ser tida como constitucionalmente obrigatória”. PASCHOAL, Janaina Conceição. Constituição, criminalização..., cit., pp. 71-72

${ }^{106}$ Como alguns intérpretes fazem, na doutrina pátria, e.g., relativamente à Lei dos Crimes Ambientais (Lei $n^{\circ}$ 9.605/1998) ou à Lei dos Crimes Hediondos (Lei no 8.072/1990). Neste sentido, cf. PASCHOAL, Janaina Conceição. Constituição, criminalização..., cit., p. 81 e ss., passim.

107 SOUZA, Luciano Anderson de Souza. Expansão do direito penal e globalização. São Paulo: Quartier Latin, 2007., pp. 87-92.

108 PASCHOAL, Janaina Conceição. Constituição, criminalização..., cit., passim. Referido por esta autora, merece menção, na literatura portuguesa, o destacado trabalho de CUNHA, Maria da Conceição Ferreira da. Constituição e crime: uma perspectiva da criminalização e da descriminalização. Porto: Universidade Católica Portuguesa, 1995.

109 "O Estado Social e Democrático não deve transformar-se, para alcançar seus objetivos de cunho social, em um Estado policial, devendo a Constituição vir a ser um limite do poder punitivo e não uma fonte cogente de incriminação”. REALE JÚNIOR, Miguel, em Prefácio à PASCHOAL, Janaina Conceição. Constituição, criminalização..., cit., p. 10. Cf., ainda, REALE JÚNIOR, Miguel. Instituições de..., cit., p. 21 e ss. 
tão-somente quando outros meios de tutela mostrarem-se ineficazes para tanto ${ }^{110}$. Ou seja, o Direito Penal é a ultima ratio de controle social ${ }^{111}$.

Dessa maneira, não poderia o constituinte estabelecer uma determinação de criminalização de condutas, quando o legislador ordinário pode, diante do mutante colorido das relações sociais, constatar, por exemplo, que outra forma de normatização jurídica, menos drástica, tem a possibilidade de desempenhar o mesmo, ou mais eficaz, papel. E no que diz respeito ao temário em foco, esta discussão é crucial, vez que é possível que o direito administrativo, e.g., delimite a contento certas questões ora tratadas pelo ramo jurídico-penal.

Não se entende, por via de conseqüência, por justificado constitucionalmente o expansionismo penal em qualquer aspecto, quiçá na seara econômica ${ }^{112}$. Em outras palavras, não se concebe haver um respaldo legitimador a priori, de cunho constitucional, para a produção de lege lata de tipos incriminadores de conteúdo econômico ${ }^{113}$.

\footnotetext{
110 "Nem todo bem, interesse ou valor estabelecido na Constituição pode ser considerado um bem jurídico com dignidade penal. Contudo, nem todo bem jurídico necessita de tutela penal, bastando, muitas vezes, a proteção por outros ramos do direito. Resta, assim, evidente o vício de se pretender fazer derivar do reconhecimento de valores e interesses na Constituição a obrigação do legislador de promover-lhes a tutela penal. Portanto, num Estado Democrático de Direito, a força normativa da constituição em relação ao direito penal volta-se obrigatoriamente à sua limitação (de modo a conferir-lhe legitimidade), e não à sua fundamentação, em sentido positivo de determinação". BECHARA, Ana Elisa Liberatore Silva. Da teoria do bem jurídico como critério de legitimidade do direito penal, mimeo, São Paulo, Tese de Livre Docência, Faculdade de Direito da Universidade de São Paulo, 2010, p. 56.

${ }^{111}$ PASCHOAL ainda observa que o ponto de vista oposto ensejaria a violação da divisão de poderes e do princípio da legalidade: "A presunção de que a Constituição obriga à criminalização, além de não coadunar com os princípios informadores do Direito penal mínimo, atenta contra princípios básicos do próprio Estado democrático de direito, quais sejam o da divisão dos poderes e o da legalidade. Isso porque, em sendo obrigatório ao legislador criminalizar, passa-se a avaliar o que caberá ao Poder Judiciário fazer na hipótese de o legislativo não cumprir esse dever". PASCHOAL, Janaina Conceição. Constituição, criminalização..., cit., p. 88.

${ }_{112}$ Ademais, o dirigismo estatal da economia não é incompatível com um Direito Penal mínimo. No mesmo sentido, BECHARA, Ana Elisa Liberatore Silva: "O princípio da intervenção mínima do Direito Penal, que postula a legitimidade da intromissão na esfera de liberdade do cidadão somente quando esta for estritamente necessária, não deixa de ser compatível com a concepção dominante do Estado intervencionista, já que a atuação positiva deste para atingir o bem-estar dos cidadãos não obriga a postular como desejável a restrição da liberdade individual além do imprescindível para sua própria proteção (...)". BECHARA, Ana Elisa Liberatore S. Delitos de acumulação e racionalidade da intervenção penal. Boletim IBCCRIM, São Paulo, n. 208, março/2010, p. 3. No mesmo sentido, v. ainda, BECHARA, Ana Elisa Liberatore Silva. Da teoria..., cit., p. 40.

${ }^{113}$ Afirmando expressamente entender que não foi esta a visão teleológica do constituinte, cf. também FERRARI, Eduardo Reale. Legislação penal..., cit., pp. 259-260.
} 
Afere-se, no entanto, certa influência prática dos interesses sinalizados como dignos de proteção pelo constituinte sobre o legislador ordinário, o qual, nas últimas décadas, vem consagrando no Brasil, como alhures, um movimento global de expansão do Direito Penal típico da sociedade do risco, o qual abarca a tutela jurídico-penal de interesses econômicos. A pertinência ou não desta postura, no que diz respeito especificamente à ordem econômica, é um dos aspectos essenciais da presente investigação científica.

\subsubsection{Conclusão}

Em termos de evolução histórica geral, a relação entre Direito Penal e economia apresentou quatro fases: a) de mero casuísmo de tratamento, que perdurou da Antigüidade à Idade Moderna; b) de proteção ao modelo econômico liberal, que tem no Sherman Act a sua consagração; c) de assecuração da política do Estado do Bem-Estar Social e d) de diminuição do papel do Estado na economia, para mero agente regulador, que tem no Sarbanes-Oxley Act seu ápice.

Desde o período de busca por proteção ao modelo liberal até os dias atuais, somente vem aumentando a repressão penal de ações de interesse da economia, embora por diversos fundamentos.

Quanto ao ordenamento brasileiro, não se constata uma correspondência exata com as fases internacionais, ao menos até recentemente. Isto pois, a partir da segunda metade do século XX, começa a despontar a criminalização econômica no Brasil, a qual se consagra, ou radicaliza, nos anos 90 , sem sistematização.

Portanto, diante da exasperação - cada vez mais intensa -, e em nível global, dessa novel criminalidade desde meados da centúria passada até os dias que correm, fundamental delimitar o significado, o alcance e a funcionalidade desta ligação entre Direito Penal e economia, com vistas à reflexão quanto à sua legitimidade em um Estado Democrático de Direito. Para tanto, forçoso preliminarmente atentar-se sobre o que se 
entende por Direito Penal Econômico e qual o papel da teoria do bem jurídico nesta compreensão.

\subsection{Pressupostos fundamentais}

\subsubsection{A compreensão de Direito Penal Econômico}

Há na doutrina o reconhecimento da ausência de uniformidade na conceituação do Direito Penal Econômico ${ }^{114}$, o que de antemão traz sérias dificuldades para a análise e sistematização da matéria ${ }^{115}$, pois sequer há convergência sobre o exato objeto tutelado pela norma penal.

Os estudos iniciais do temário, de meados do século $\mathrm{XX}$, devidos a SUTHERLAND $^{116}$ e a CLINARD ${ }^{117}$, atrelavam a idéia do delito econômico a seu autor, tido como "homem de negócios" (de "colarinho branco"), em contraposição ao delinqüente dito tradicional, pertencente às classes populares (de "colarinho azul”). Como afirmado, o ideário focava sua análise da associação diferencial sobre a delinqüência cometida pelos indivíduos economicamente mais providos da sociedade

A visão descritiva, de cunho criminológico ${ }^{118}$, de tais autores não pode, todavia, ser adotada como referencial normativo para criminalização ${ }^{119}$, sendo de fato

\footnotetext{
114 Cf., dentre outros: TIEDEMANN, Klaus. Poder económico..., cit., p. 9; GRACIA MARTíN, Luis. Prolegómenos para la lucha por la modernización y expansión del derecho penal y para la crítica del discurso de resistencia. Valencia: Tirant lo Blanch, 2003, p. 66; PIMENTEL, Manoel Pedro. Direito penal econômico. São Paulo: Revista dos Tribunais, 1973, p. 12; DIAS, Jorge de Figueiredo \& ANDRADE, Manuel da Costa. Problemática geral..., cit., p. 332; FERRARI, Eduardo Reale. Legislação penal..., cit., p. 263.

115 TIEDEMANN, Klaus. Poder económico..., cit., p. 9.

${ }^{116}$ SUTHERLAND, Edwin H. El delito..., cit., passim.

${ }^{117}$ CLINARD, Marshall B. Black market: a study of white collar crime. Montclair: Patterson Smith, 1969, passim; Posteriormente, cf.: CLINARD, Marshall B. \& YAGER, Peter C. Corporate crime. Somerset: Transaction, 2005, passim.

${ }^{118}$ GRACIA MARTÍN, Luis. Prolegómenos..., cit., p. 67. Para JOSÉ DE FARIA COSTA, "Estamos perante um caso de particular relevo para se ter uma correcta percepção das relações entre o direito penal e a criminologia. Como se sabe, aquela feliz qualificação cunhou-a Edwin Sutherland e significou uma 'pequena revolução coperniciana' não só nos modos de investigação da criminologia mas também um enorme enriquecimento no que se refere ao próprio direito penal (...)". COSTA, José de Faria. Direito penal económico. Coimbra: Quarteto, 2003, p. 81.

${ }^{119}$ SILVEIRA, Renato de Mello Jorge. Direito penal econômico..., cit., p. 65, nota 4.
} 
inaceitável diante de um Direito Penal de matriz liberal, voltado ao fato ilícito, independentemente das características pessoais de seu autor. Ademais, referida visão já não se sustentaria diante da simples constatação de que o crime econômico muitas vezes possui como autor material simples empregado ou interposta pessoa de um "homem de negócios" ou, ainda, indivíduo desprovido economicamente, mas que almeja com a ilicitude uma posição superior.

De outro lado, apesar da inegável importância dos contextos empresariais na delinqüência econômica, como os próprios estudos de SUTHERLAND e CLINARD apontam, tampouco se revela adequado o pensamento que relaciona a infração penal econômica àquela de empresa (corporate crime) ${ }^{120}$, ator econômico de negócios de maior vulto típico de nossa era. Isso porque referido entendimento - abstraindo-se neste ponto da precisa discussão da possibilidade ou não de responsabilidade penal da pessoa jurídica, isto é, de sua consideração como sujeito ativo de infrações penais - apresenta o mesmo vício reducionista do entendimento anterior, que ignora que a norma penal veda condutas e que, no caso da delinquiência econômica, pode-se utilizar ou não de um ente moral para realização das ações proibidas.

A compreensão de um Direito Penal da Empresa como ramo do Direito Penal Econômico ${ }^{121}$ pode até se revelar útil em termos de metodologia de estudo, mormente para fins de investigações criminológicas, mas não se revela adequada para caracterizar em termos de essência o que vem a ser o Direito Penal Econômico. Ou seja, em que pese a relevância do ambiente empresarial na perpetração de comportamentos econômicos socialmente indesejados, o Direito Penal Econômico não é exclusivamente um Direito Penal de Empresa. Em outras palavras, o crime econômico não é exclusivamente o crime empresarial. O sentido amplo pretendido por autores como TERRADILLOS BASOCO ${ }^{122}$

\footnotetext{
120 Tendência da doutrina francesa e sueca, segundo TIEDEMANN, cf. TIEDEMANN, Klaus. Poder económico..., cit., p. 10. Cf. ainda, e.g., salvo algumas nuances apontadas, TERRADILLOS BASOCO, Juan M. Empresa y derecho penal. Buenos Aires: Ad-Hoc, 2001, p. 34-35; SCHÜNEMANN, Bernd. ¿Ofrece la reforma del derecho penal económico alemán un modelo o un escarmiento? Trad. Lourdes Baza. Temas actuales y permanentes del derecho penal después del milenio. Madrid: Tecnos, 2002, p. 192. V. também o destacado trabalho especificamente acerca do tema de ALEXANDER, Cindy R. Corporate crime, markets and enforcement: a review. New perspectives on economics crime. Northampton: Edward Elger, 2004.

${ }^{121}$ TERRADILLOS BASOCO, Juan M. Derecho penal de la empresa. Madrid: Trotta, 1995, p. 10.

122 TERRADILLOS BASOCO, Juan M. Empresa y..., cit., passim.
} 
ao Direito Penal de Empresa abarca condutas tão distintas como crimes falimentares, contra a livre concorrência, ambientais e tributários, os quais, a despeito de efetivamente não possuírem uma identidade de interesse tutelado, podem ser perpetrados fora de uma específica realidade empresarial.

Ainda neste contexto, parte da literatura especializada alemã e norteamericana, afastando-se da simples consideração de autoria ou de exclusiva utilização de ente coletivo para a prática do ilícito, mas em certo sentido utilizando-se de tais idéiasforça, emprega o conceito de "fato penal profissional" (occupational crime ou occupational deviant ${ }^{123}$. Assim, para uma concepção deste jaez, o crime econômico seria aquele perpetrado de modo profissional no bojo de uma atividade econômica.

Embora pareça mais adequado que os entendimentos anteriores, já que há enfoque no fato e não exclusivamente em seu autor ou no meio de execução delitiva, o pensamento do occupational crime verdadeiramente ainda desvela grande imprecisão, eis que pode englobar genericamente sob a mesma compreensão fatos tão distintos praticados de forma profissional com intuito de lucro ilícito como, e.g., o tráfico de drogas, o crime falimentar, a sonegação fiscal, a extorsão mediante seqüestro e a agressão à livre concorrência.

Também já se buscou definir doutrinariamente a delinqüência econômica consoante uma perspectiva criminalística ${ }^{124}$ :

A partir da circunstância de os crimes económicos, em virtude de sua normal complexidade, só poderem ser investigados e julgados mediante processos especiais, por polícias e magistrados dotados de conhecimentos da moderna vida económica e mediante o dispêndio de avultadas quantias, foi-se ao ponto de negar qualquer outra nota identificadora do crime contra a economia ${ }^{125}$.

\footnotetext{
${ }^{123}$ TIEDEMANN, Klaus. Poder económico..., cit., pp. 10-11; PIMENTEL, Manoel Pedro. Direito penal..., cit., p. 28.

${ }^{124}$ TIEDEMANN, Klaus. Poder económico..., cit., p. 12; TIEDEMANN, Klaus. Derecho penal..., cit., pp. 70-71.

${ }^{125}$ DIAS, Jorge de Figueiredo \& ANDRADE, Manuel da Costa. Problemática geral..., cit., p. 333.
} 
Assim, em face das especificidades de sua apuração, qualificar-se-iam os crimes econômicos, o que se revela inapropriado por se distanciar dos fundamentos dogmáticos da questão, apegando-se a algo singelamente atrelado à práxis investigativa ${ }^{126}$.

Por fim, destaca-se na literatura penal econômica a distinção proposta por TIEDEMANN, encampada na doutrina espanhola por autores como BAJO FERNÁNDEZ, entre Direito Penal Econômico em sentido estrito e Direito Penal Econômico em sentido $\operatorname{amplo}^{127}$.

Segundo a compreensão estrita, este ramo abrangeria apenas as infrações voltadas à tutelar a intervenção estatal na ordenação do mercado ${ }^{128}$. Incluir-se-iam, assim, neste espectro, delitos de usura, evasão de divisas e sonegação fiscal, vez que o intuito normativo seria o de "proteger os objetivos da planificação estatal" da economia ${ }^{129}$.

Já em sentido amplo, que ganha a adesão do autor alemão referido, o Direito Penal Econômico compreenderia:

(...) em primeiro lugar, as violações no âmbito do Direito AdministrativoEconômico, isto é, contra a atividade interventora e regulatória do Estado na economia. Abrange também as infrações aos demais bens jurídicos coletivos ou supra-individuais da vida econômica, os quais, por necessidade conceitual, transcendem os bens jurídicos individuais. E inclui, finalmente, os delitos patrimoniais clássicos (estelionato, extorsão, falsificação, corrupção, etc.), quando estes se dirigem contra patrimônios supra-individuais (como nos casos de obtenção fraudulenta de subvenções ou créditos estatais) ou quando constituem abuso de medidas e instrumentos da vida econômica (como nas hipóteses de um cheque sem fundos ou um falso balanço) ${ }^{130}$.

\footnotetext{
${ }^{126}$ Nas palavras de DIAS e ANDRADE: “(...) Tratar-se-ia de crimes patrimoniais qualificados apenas pela complexidade de sua prática e, consequentemente, da sua investigação. É; uma perspectiva igualmente inadequada. Eleva à categoria de nota essencial dum fenómeno uma sua característica (apenas) normal e que, por isso, não satisfaz as exigências da dogmática e da política criminal". DIAS, Jorge de Figueiredo \& ANDRADE, Manuel da Costa. Problemática geral..., cit., p. 333.

${ }^{127}$ GARCÍA CAVERO, Percy. Derecho penal..., cit., pp. 21-22.

128 "O Direito Penal Econômico, em sentido estrito, é concebido como 'direito de direção da economia pelo Estado’ (...)”.TIEDEMANN, Klaus. Poder económico..., cit., p. 19 (tradução livre).

${ }^{129}$ TIEDEMANN, Klaus. Poder económico..., cit., p. 19 (tradução livre).

${ }^{130}$ TIEDEMANN, Klaus. Poder económico..., cit., p. 12 (tradução livre).
} 
Posteriormente, também no mesmo sentido, mas, consoante entendemos, alargando ainda mais sua compreensão, TIEDEMANN explicita que se inclui no bojo do referido Direito Administrativo-Econômico os temas afetos a tributos, subvenções, sistema creditício, mercado de capitais, proteção ao consumidor, letras de câmbio, etc., defendendo que o Direito Penal Econômico é parte integrante do Direito Econômico ${ }^{131}$.

Não se coaduna, contudo, dessa visão político-criminal excessivamente ampla de TIEDEMANN, quer pela ausência de unidade de sentido a justificar tipos incriminadores de substratos tão díspares como os citados, quer pela autonomia do Direito Penal relativamente ao Direito Econômico, assim como, por fim, pela carência de um critério claro e seguro capaz de limitar a repressão penal do Estado. Já a visão estrita, rechaçada pelo doutrinador, curiosamente, também se nos afigura vaga, carente de maior concretude necessária numa construção jurídico-criminal, e, especificamente, pouco clara quando se procura distinguir o Direito Penal Econômico do Direito Econômico, eis que este certamente busca regrar a direção estatal da economia.

Nesse diapasão, consoante se desenvolve a seguir, verifica-se a necessidade de identificação do bem jurídico penal econômico. Isto porque apenas a proteção de bens jurídicos com dignidade penal representa o referencial interpretativo material deste ramo do Direito.

\subsubsection{A proteção de bens jurídicos como referência interpretativa material do Direito Penal}

A solução metodológica que desponta coerente com a nossa evolução jurídico-penal, que remonta aos ideais da Ilustração, é a preliminar perquirição acerca do bem jurídico tutelado: "O fim de prover à segurança tutelando bens jurídicos é o que marca um limite racional à aspiração ética do direito penal (...)"132.

\footnotetext{
${ }^{131}$ TIEDEMANN, Klaus. Derecho penal..., cit., p. 77.

${ }^{132}$ Cf. ZAFFARONI, Eugenio Raúl \& PIERANGELI, José Henrique. Manual de direito penal brasileiro. São Paulo: Revista dos Tribunais, 2008, p. 90.
} 
O Estado somente pode cercear da maneira mais drástica - com a sanção penal - um comportamento humano que ofenda de modo significativo um bem jurídico fundamental à convivência social, o qual não pode ser tutelado de outro modo menos gravoso $^{133}$. Este é um critério essencial para a análise da referência material de uma incriminação que se consolidou na tradição da dogmática jurídico-penal ${ }^{134}$. Somente desse modo é possível, concomitantemente, justificar um tipo incriminador e oferecer um delimitador seguro contra o arbítrio do Estado.

A noção de bem jurídico ${ }^{135}$ remonta à contraposição feita por JOHANN MICHAEL FRANZ BIRNBAUM, em 1834, às idéias de JOHANN ANSELM RITTER VON FEUERBACH de lesão a direitos subjetivos como núcleo material do delito, desenvolvidas por este último anos antes para fins de negar quaisquer fundamentações teocráticas no Direito Penal. Embora haja autores que vislumbrem em FEUERBACH a origem do conceito de bem jurídico, adota-se o entendimento doutrinário majoritário de que a noção mais aproximada surgirá da crítica de BIRNBAUM às idéias daquele autor, uma vez que "bem" liga-se mais propriamente à idéia de objeto que a de direito ${ }^{136}$.

${ }^{133}$ HASSEMER, Winfried. ¿Puede haber delitos que no afecten a um bien jurídico penal? In: HEFENDEHL, Roland (Ed.). La teoría del bien jurídico: ¿fundamento de legitimación del derecho penal o juego de abalorios dogmático? Madrid: Marcial Pons, 2007, p. 95 e ss.

${ }^{134}$ Cf., dentre outros: MIR PUIG, Santiago. Derecho penal: parte general. Montevideo-Buenos Aires: B de F, 2005, p.129; COSTA, Helena Regina Lobo da. Proteção penal ambiental: viabilidade, efetividade, tutela por outros ramos do direito. São Paulo: Saraiva, 2010, pp. 1-2.; BECHARA, Ana Elisa Liberatore S. Manipulação genética humana e direito penal. Porto Alegre: Zouk, 2007, p.171; BECHARA, Ana Elisa Liberatore Silva. Da teoria..., cit., p. 88 e ss., passim.

${ }^{135}$ Far-se-á breve menção histórica da evolução do conceito de bem jurídico apenas para ressaltar seu marco referencial numa específica incriminação, como no caso da de cunho econômico. Com profundidade, na literatura nacional, dentre outros, cf.: PRADO, Luiz Regis. Bem jurídico-penal e constituição. São Paulo: Revista dos Tribunais, 1997, p. 25 e ss.; TAVARES, Juarez. Teoria do injusto penal. Belo Horizonte: Del Rey, 2002, p. 181 e ss.; SILVEIRA, Renato de Mello Jorge. Direito penal supra-individual: interesses difusos. São Paulo: Revista dos Tribunais, 2003, p. 36 e ss.; PASCHOAL, Janaina Conceição. Constituição, criminalização..., cit., p. 26 e ss.; SALOMÃO, Heloisa Estellita. A tutela penal e as obrigações tributárias na constituição federal. São Paulo: Revista dos Tribunais, 2001, p. 25 e ss.; COELHO, Yuri Carneiro. Bem jurídico-penal. Belo Horizonte: Mandamentos, 2003, p. 31 e ss.; BECHARA, Ana Elisa L. Silva. O rendimento da teoria do bem jurídico no direito penal atual. Revista Liberdades, São Paulo, v. 1, n. 1, mai./ago. 2009, p. 17 e ss.; BECHARA, Ana Elisa Liberatore Silva. Da teoria..., cit., p. 88 e ss.; PONTE, Antonio Carlos da. Crimes eleitorais..., cit., p. 147 e ss. Na doutrina estrangeira, vide, por exemplo, dentre inúmeros outros: POLAINO NAVARRETE, Miguel. El bien jurídico em derecho penal. Sevilla: Publicaciones de la Universidad de Sevilla, 1974, passim; HORMAZABAL MALARÉE, Hernán. Bien jurídico y estado social e democratico de derecho: el objeto protegido por la norma penal. Santiago de Chile: CONOSUR, 1992, p. 14 e ss.; BUSTOS RAMÍREZ, Juan. Introducción al derecho penal. Bogotá: Temis, 1994, p. 24 e ss.; ANDRADE, Manuel da. Consentimento e acordo em direito penal. Coimbra: Coimbra, 1991, p. 42 e ss.; CUNHA, Maria da Conceição Ferreira da. Constituição e..., cit., p. 29 e ss.

${ }^{136}$ A respeito do tema, cf., e.g., CUNHA, Maria da Conceição Ferreira da. Constituição e..., cit., p. 30. 
Sem utilizar a exata expressão bem jurídico, BIRNBAUM amplia o espectro de consideração do conteúdo material do crime, desenvolvendo seu pensamento no sentido de que uma incriminação deve sempre estar baseada não em um direito, mas num objeto, de cunho liberal, valorado pelo Estado, representativo de interesses essenciais do indivíduo na vida social ${ }^{137}$. Tal compreensão decorre do fato de que o Direito se baseia na razão humana e no contrato social, não se justificando quer por uma idéia divina ou natural.

O primeiro autor a utilizar o termo "bem jurídico" foi KARL BINDING, o qual, com uma visão positivista, entendia que o crime seria a lesão a um direito subjetivo do Estado, sendo o bem jurídico aquilo que a lei estabelecesse neste sentido. Ainda dentro dos ideais da escola positiva, mas numa linha naturalística-sociológica ${ }^{138}$ e procurando superar as críticas de mero formalismo na definição de BINDING, FRANZ VON LISZT trouxe a compreensão de bens jurídicos como interesses sociais vitais, baseados em circunstâncias sociais concretas ${ }^{139}$. Dessa maneira, eles não seriam decorrência do sistema jurídico, mas sim prévios, decorrentes da realidade social.

A partir dos anos 20 do século passado, com o ideário neokantista, abandonase o viés liberal do bem jurídico, ressaltando-se sua concepção teleológica, isto é, interpretando-o a partir de seu fim, que é visto nos valores comunitários. Tal se deu pois essa doutrina fundamentou o conceito de ciência do espírito, como o Direito, no método e não no objeto, dando lugar a uma filosofia axiológica ${ }^{140}$.

Durante o período do regime nacional-socialista alemão, a teoria do bem jurídico foi criticada por se entender que seria inadequada ao novo modelo de Estado por seu individualismo e liberalismo ${ }^{141}$. Tendo em vista a mácula trazida ao Direito Penal pela

\footnotetext{
${ }^{137}$ BECHARA, Ana Elisa L. Silva. O rendimento da..., cit., pp. 17-18.

${ }^{138}$ BECHARA, Ana Elisa L. Silva. O rendimento da..., cit., p. 18.

139 "Liszt defendia que o bem jurídico penal não é criado pelo legislador, sendo sim identificado por ele no cenário social e, posteriormente, protegido mediante a norma penal. Pode-se, portanto, dizer ter sido Liszt o primeiro a expressamente defender a idéia de um bem jurídico penal material". PASCHOAL, Janaina Conceição. Constituição, criminalização..., cit., p. 33.

${ }^{140}$ PRADO, Luiz Regis. Bem jurídico-penal..., cit. p. 33, nota de rodapé 20.

${ }^{141}$ MIR PUIG, Santiago. Derecho penal..., cit., p. 129; GRECO, Luís. Breves reflexões sobre os princípios da proteção de bens jurídicos e da subsidiariedade no direito penal. In: SCHMIDT, Andrei Zenkner. Novos
} 
Escola de Kiel neste período antidemocrático e de horror, subseqüentemente nota-se uma revalorização do conceito de bem jurídico ${ }^{142}$.

Com o fim do conflito mundial, as concepções humanistas do jusnaturalismo de HANS WELZEL ${ }^{143}$, iniciadas nos anos 30, foram retomadas. O autor alemão procura fundamentar o sistema delitivo consoante o ontologismo, a partir das estruturas lógicoobjetivas, ou da natureza das coisas. A ação humana, que precede ao Direito, é uma estrutura lógico-objetiva fundamental, em face da capacidade humana de previsão do resultado de seu agir. "É por isso que WELZEL afirma que a estrutura ontológica da ação precede a qualquer regulamentação, constituindo estrutura que se há de respeitar ao querer regular condutas" $" 144$.

Nesse sentido, sobreleva em importância a consideração do desvalor da ação na análise delitiva. Apesar de referenciar o bem jurídico como interesse vital da coletividade e do indivíduo, a teoria finalista de WELZEL, não o destaca em sua construção. Todavia, possuiu o mérito de ter retomado a idéia de seu conteúdo material, ensejando as reflexões que vieram a seguir acerca da legitimidade da intervenção jurídicopenal $^{145}$.

Neste influxo, a compreensão do temário, dentre concepções sociológicas, constitucionais ou sistêmicas, passou a, principalmente ${ }^{146}$, demonstrar escora na Constituição: os bens jurídicos seriam concretizações de valores constitucionais relacionados aos direitos fundamentais ${ }^{147}$. Isto significa que o cerne do sistema valorativo é

rumos do direito penal contemporâneo: livro em homenagem ao Prof. Dr. Cezar Roberto Bitencourt. Rio de Janeiro: Lumen Juris, 2006, p. 402.

${ }^{142}$ SILVEIRA, Renato de Mello Jorge. Direito penal supra-individual..., cit., p. 48; BECHARA, Ana Elisa Liberatore Silva. Da teoria..., cit., p. 112.

${ }^{143}$ WELZEL, Hans. Derecho penal alemán. Trad. Juan Bustos Ramírez e Sérgio Yáñez Pérez. Santiago de Chile: Editorial Juídia de Chile, 1993.

${ }^{144}$ REALE JÚNIOR, Miguel. Instituições de..., cit., p. 127.

145 BECHARA, Ana Elisa Liberatore Silva. Da teoria..., cit., p. 114.

${ }^{146}$ GRECO, Luís. Breves reflexões..., cit., p. 406. O autor noticia as respostas alternativas de ZACZYK, que se apóia na filosofia de KANT e FICHTE, e KINDHÄUSER, que recorre à filosofia analítica da linguagem. GRECO, Luís. Breves reflexões..., cit., p. 406, nota 28.

${ }^{147}$ BECHARA, Ana Elisa L. Silva. O rendimento da..., cit., p. 20. 
a pessoa humana ${ }^{148}$. Nas palavras de CLAUS ROXIN, bens jurídicos são então “(...) realidades ou fins que são necessários para uma vida social livre e segura a qual garanta os direitos humanos e fundamentais do indivíduo, ou para o funcionamento do sistema estatal erigido para a consecução de tal fim" $" 149$.

A sociedade do risco atual, com suas novéis problemáticas e necessidades, tem levado a um constante repensar da teoria do bem jurídico por parcela da doutrina. Por um lado, no sentido de sua utilização não mais como critério crítico e limitativo da tipificação penal, mas, ao revés, como justificativa para aumento do espectro de incidência do Direito Penal, como o faz, por exemplo, BERND SCHÜNEMANN, na Alemanha, e LUIS GRACIA MARTÍN, na Espanha ${ }^{150}$. Assim é que se procura justificar dogmaticamente a tendência expansionista jurídico-penal.

De outra parte, a reflexão acerca do conceito desponta no sentido de abstrair dele como condição essencial para legitimidade de uma proibição penal ${ }^{151}$. Dito de outro modo, uma incriminação poderia ter finalidade diversa da de proteção de bens jurídicos. É o entendimento, e.g., de autores como GÜNTHER STRATENWERTH, GÜNTHER JAKOBS, KNUT AMELUNG, ANDREW VON HIRSCH e, mais recentemente, o posicionamento revelado por ROXIN.

Propondo a substituição da noção de bem jurídico pela de relações da vida por si mesmas ${ }^{152}$, em face da imprecisão daquela, anota STRATENWERTH:

\footnotetext{
${ }^{148}$ COSTA, Helena Regina Lobo da. Proteção penal..., cit., p. 5; TAVARES, Juarez. Teoria do..., cit., p. 199; BECHARA, Ana Elisa Liberatore S. Manipulação genética..., cit., p. 169.

${ }^{149}$ ROXIN, Claus. ¿Es la protección de bienes jurídicos uma finalidad del derecho penal? In: HEFENDEHL, Roland (Ed.). La teoría..., cit., p. 448 (tradução livre). Na doutrina nacional, este conceito é criticado, e.g., por FÁBIO ROBERTO D'AVILA, para quem a palavra “fins" expressaria assentimento para a criação de bens jurídicos por parte do legislador. Cf. D'AVILA, Fábio Roberto. Aproximações à teoria da exclusiva proteção de bens jurídicos no direito penal contemporâneo. Revista Brasileira de Ciências Criminais, São Paulo, n. 80, set.-out. 2009, p. 18, nota 35.

${ }^{150}$ Cf. SCHÜNEMANN, Bernd. Sobre la dogmática y la política criminal Del derecho penal del médio ambiente. Cuadernos de Doctrina y Jurisprudencia Penal, Buenos Aires, v. 5, n. 9, 1999, pp. 627-628; GRACIA MARTÍN, Luis. Prolegómenos para..., cit., passim. Sobre o tema, cf.: COSTA, Helena Regina Lobo da. Proteção penal..., cit., p. 8; BECHARA, Ana Elisa L. Silva. O rendimento da..., cit., pp. 21-22; BECHARA, Ana Elisa Liberatore Silva. Da teoria..., cit., pp. 123-124.

${ }^{151}$ GRECO, Luís. Breves reflexões..., cit., pp. 409-410.

${ }^{152}$ Ou "relações da vida como tais", como traduz do alemão, p. ex., DIAS e COSTA. Cf. DIAS, Jorge de Figueiredo. O papel do direito penal na protecção das gerações futuras. In: INSTITUTO DE DIREITO
} 
Apesar de múltiplos esforços, até hoje não houve êxito em se esclarecer o conceito de bem jurídico nem ao menos de modo aproximado. Ao revés, todas as tentativas fracassaram pela dificuldade, de fato de impossível superação, já preliminar, de se encontrar uma definição que se ajuste a todos os tipos penais cuja legitimidade esteja fora de questão e que, apesar disso, ainda expresse algo. Ao contrário, o conceito recebe concretude somente na medida em que se trate de interesses individuais (vida, integridade corporal, liberdade, etc.), enquanto que, ampliado aos chamados bens jurídicos universais (como o interesse da comunidade na correta condução de um processo, no respeito à religião, na veracidade dos documentos, etc.), apenas caracteriza a idéia básica em que se funda a disposição penal. (...) Somente se poderia superar esta dificuldade caso se pudesse partir da premissa de que os interesses da pessoa se orientam exclusivamente por si mesmos ${ }^{153}$.

JAKOBS, por sua vez, em sua visão funcionalista sistêmica ${ }^{154}$, entende que o crime é um ato de infidelidade ao ordenamento jurídico, sendo a sanção penal uma resposta de reafirmação da vigência da norma vilipendiada pela prática ilícita ${ }^{155}$. Assim, os tipos penais, por meio do sistema de penas, protegem expectativas sociais de condutas, referenciadas nos papéis das pessoas num contexto social determinado ${ }^{156}$, e não

PENAL ECONÓMICO E EUROPEU - FACULDADE DE DIREITO DA UNIVERSIDADE DE COIMBRA. Direito penal económico e europeu: textos doutrinários. Coimbra: Coimbra, 2009, V. III, p. 614; COSTA, Helena Regina Lobo da. Proteção ambiental..., cit., p. 18. O pensamento de STRATENWERTH aproxima-se da idéia de que um tipo penal tem por objetivo não a proteção de bens jurídicos, mas vedar comportamentos sociais inconvenientes. Neste sentido: ROXIN, Claus. A proteção de bens jurídicos como função do direito penal. Trad. André Luís Callegari e Nereu José Giacomolli. Porto Alegre: Livraria do Advogado, 2009, p. 15.

${ }^{153}$ STRATENWERTH, Günther. Derecho penal: parte general: el hecho punible. Buenos Aires: Hammurabi, 2005, pp. 65-66 (tradução livre).

${ }^{154}$ Sobre o tema, na doutrina nacional, todos com visão crítica, e.g., cf. REALE JÚNIOR, Miguel. Instituições de..., cit., pp. 53-54; PRADO, Luiz Regis. Curso de direito penal brasileiro, volume 1: parte geral, arts. $1^{\circ}$ a 120. São Paulo: Revista dos Tribunais, 2004, pp. 108-113; BITENCOURT, Cezar Roberto. Tratado de direito penal: parte geral. São Paulo: Revista dos Tribunais, 2006, V. I, pp. 95-99; TAVARES, Juarez. Teoria do..., cit., pp. 65-67 e 196 e ss.

${ }_{155}$ JAKOBS, Günther. Tratado de direito penal: teoria do injusto penal e culpabilidade. Trad. Gercélia Batista de Oliveira Mendes e Geraldo de Carvalho. Belo Horizonte: Del Rey, 2009, p. 19 e ss., passim.

156 "Pode-se tentar apresentar o direito penal como proteção dos bens jurídicos, mas só de modo bastante forçado. O direito é a estrutura da relação entre pessoas, que por sua vez podem ser representadas como titulares de determinados papéis; a determinação do comportamento não permitido através de diversos institutos da chamada imputação objetiva - hoje, amplamente reconhecida - obriga, a levar em consideração o contexto social, a determinar um papel social, inclusive para os deveres negativos (...). A teoria do direito penal como proteção da vigência da norma demonstra sua validade especialmente na teoria dos fins da pena: o fato é uma lesão da vigência da norma, a pena é a sua eliminação". JAKOBS, Günther. O que protege o Direito Penal: os bens jurídicos ou a vigência da norma? Trad. Nereu José Giacomolli. In: CALLEGARI, André Luís \& GIACOMOLLI, Nereu José (Coords.). Direito penal e funcionalismo. Porto Alegre: Livraria do Advogado, 2005, p. 51. 
propriamente bens jurídicos ${ }^{157}$. Segundo o autor alemão, a punibilidade há então que se orientar não pelo que é contrário ao valor per si, mas pela nocividade social da conduta ${ }^{158}$.

De modo mais radical que JAKOBS, uma vez que para este parte das incriminações que passam pelo filtro da nocividade social seriam relativas à proteção de bens jurídicos ${ }^{159}$, que dariam validade fática às normas correspondentes, AMELUNG afirma que a teoria do bem jurídico é simplesmente inútil, havendo de ser substituída pelo conceito de danosidade social. Influenciado pela teoria sistêmica social com base em TALCOTT PARSONS e NIKLAS LUHMANN, entende o autor tedesco que a Constituição impõe que se proíbam tão-somente condutas socialmente danosas, decorrendo disso que a norma penal apenas pode ser aplicada de forma que dela resulte uma contribuição para a manutenção do sistema social ${ }^{160}$.

A seu turno, ANDREW VON HIRSCH, após analisar o princípio do dano e refletindo sobre criminalizações como as relativas ao meio ambiente, como no caso de proteção às baleias, e "delitos de conduta" (Verhaltensdelikte), como na hipótese de respeito aos mortos, conclui que o bem jurídico por si só não pode conformar uma teoria adequada a justificar o fenômeno criminalizador, devendo-se perseguir critérios que possam ir mais além dessa noção ${ }^{161}$.

Nesta seara, ainda sem maior desenvolvimento, o próprio ROXIN ${ }^{162}$ já altera sua anterior ${ }^{163}$ compreensão crítica:

\footnotetext{
${ }^{157}$ JAKOBS, Günther. Tratado de..., cit., p. 61 e ss.

${ }^{158}$ JAKOBS, Günther. Tratado de..., cit., p. 78.

159 JAKOBS, Günther. Tratado de..., cit., p. 78.

${ }^{160}$ ANDRADE, Manuel da. Consentimento e acordo..., cit., p. 97.

${ }^{161}$ HIRSCH, Andrew Von. El concepto de bien jurídico y el "principio del daño". In: HEFENDEHL, Roland (Ed.). La teoría..., cit., pp. 37-52. Cf., também, do autor: HIRSCH, Andrew Von. I concetti di "danno" e "molestia" come criteri politico-criminali nell'ambito della dottrina penalistica angloamericana. In: FIANDACA, Giovanni \& FRANCOLINI, Giovanni (a cura di). Sulla legittimazione del diritto penale: culture europeo-continentale e anglo-americana a confronto. Torino: G. Giappichelli, 2008, pp. 29-42.

${ }^{162}$ Em obra ainda não traduzida às línguas latinas ou ao inglês.

${ }^{163}$ A qual afirmava a concepção pessoal do bem jurídico, ainda que por vezes relacionada a fins necessários para coexistência livre e pacífica - desta maneira, com base em idealizações e não apenas realidades. Vide: ROXIN, Claus. Derecho penal: parte general: tomo I: fundamentos - la estructura de la teoria del delito. Trad. Diego-Manuel Luzón Peña, Miguel Díaz y García Conlledo e Javier de Vicente Remesal. Madrid: Civitas, 2008, p. 51 e ss.; ROXIN, Claus. ¿Es la protección..., cit., p. 443 e ss.; ROXIN, Claus. A proteção de..., cit., passim.
} 
Roxin, na mais recente edição de sua obra Direito Penal - Parte Geral, admite a possibilidade de um alargamento do âmbito do direito penal para além da proteção de bens jurídicos. $\mathrm{O}$ autor não abandona por completo o conceito de bem jurídico, mas defende que ele não mais se ajusta às características dos tempos atuais, devendo-se, pois, admitir o uso do direito penal para as seguintes esferas, em que não há bem jurídico: proteção de embriões, proteção de plantas e animais, e proteção da vida das próximas gerações ${ }^{164}$.

Entre os autores brasileiros, apesar de ostentar sua sede de estudos na Alemanha, este é o entendimento, por exemplo, de LUIS GRECO ${ }^{165}$.

Apesar da negativa de utilidade da teoria do bem jurídico, ou mera mitigação desta, como critério de legitimação do fenômeno incriminador, por parcela da doutrina, o fato é que o Direito Penal representa violenta intromissão na esfera dos direitos fundamentais da pessoa, razão pela qual necessita de critérios limitadores não apenas formais, mas principalmente materiais, sob pena de consagração do arbítrio estatal.

Neste influxo, a noção de bem jurídico representa uma conquista da humanidade em face da força do Estado cujo parâmetro não foi superado por qualquer outra proposta mais coerente. Aliás, avulta em importância a teoria como meio de contenção do poder do Estado em razão do citado movimento expansionista penal das últimas décadas.

As propostas de abandono ou substituição da idéia de bem jurídico revelaramse até o momento imprecisas e pouco harmoniosas, permeadas por conceitos vagos e utilitaristas, sem maior concretude conformadora de um critério seguro de limitação do arbítrio do Estado. O fato de hipóteses de criminalizações específicas não apresentarem um

\footnotetext{
${ }^{164}$ COSTA, Helena Regina Lobo da. Proteção penal..., cit., p. 13 (itálicos originais). No mesmo sentido, BECHARA, Ana Elisa L. Silva. O rendimento da..., cit., p. 25; SILVEIRA, Renato de Mello Jorge. Fundamentos da adequação social em direito penal. São Paulo: Quartier Latin, 2010, p. 47. A obra referida de ROXIN é: ROXIN, Claus. Strafrecht. Allgemeiner Teil. Band I. Grundlagen Aufbau der Verbrechenslehre. 4. ed. Munique: C. H. Beck, 2006. Cf., também, ROXIN, Claus. ¿Es la protección..., cit., p. 443 e ss.

${ }^{165}$ GRECO, Luís. Breves reflexões..., cit., p. 410.
} 
real ou convincente bem jurídico ${ }^{166}$ de estatura penal revelam muito mais a inadequação de tais tipos penais do que da teoria do bem jurídico.

Não se admite então um crime sem bem jurídico tutelado, que é o fundamento necessário e constitucional tanto para conceber um dever de proteção como para determinar os limites à intervenção e seu cálculo preciso:

A determinação da missão do direito penal com a ajuda do conceito de bem jurídico oferece ao legislador um critério plausível e prático na hora de tomar decisões e, simultaneamente, um critério externo de comprovação da justiça dessas decisões. Esse critério, ao mesmo tempo que utilizável, deve ser facilmente apreendido a fim de evitar que o legislador possa ameaçar com uma pena tudo 'aquilo que em sua opinião deva ser mantido intacto e sem nenhuma alteração'. A idéia do bem jurídico conduz, portanto, a uma política criminal racional: o legislador penal deve medir suas decisões com critérios justos e claros, utilizando-os ao mesmo tempo para sua justificação e crítica. Tudo que não tenha a ver com a proteção do bem jurídico deve ser excluído do âmbito de proteção do direito penal ${ }^{167}$.

Ainda, nas precisas palavras de REALE JÚNIOR:

Os valores fundamentais da Justiça e da liberdade exigem que o legislador, ao construir as normas incriminadoras, arcabouço do Direito Penal, tenha em vista os bens jurídicos considerados dignos de tutela. O bem jurídico preexiste à

${ }^{166}$ Como no exemplo de crime de maus tratos a animais, que, consoante entendemos, não parece possuir um bem jurídico de natureza penal, vez que não claramente representativo de um aferível elemento fundamental para o livre desenvolvimento humano em sociedade. Neste sentido, v. SCHÜNEMANN, Bernd. O direito penal é a ultima ratio da proteção de bens jurídicos! - Sobre os limites invioláveis do direito penal em um Estado de Direito liberal. Trad. Luís Greco. Revista Brasileira de Ciências Criminais, n. 53, v. 13, 2005, p. 17. Citado texto possui uma edição exclusiva em língua espanhola: SCHÜNEMANN, Bernd. ¡El derecho penal es la ultima ratio para la protección de bienes jurídicos! Sobre los limites inviolables del derecho penal en um estado liberal de derecho. Trad. Ángela de la Torre Benítez. Bogotá: Universidad Externado de Colômbia, 2007. Sobre o tema em foco, e.g., cf. ainda: MANES, Vittorio. Il principio di ofensività nel diritto penale: canone di politica criminale, criterio ermeneutico, parametro di ragionevolezza. Torino: G. Giappichelli, 2005, pp. 124-126. Na doutrina nacional, cf. COSTA, Helena Regina Lobo da. Proteção penal..., cit., pp. 30-33; GRECO, Luís. Proteção de bens jurídicos e crueldade com animais. Revista Liberdades, n. 3, jan.-abr. 2010, pp. 47-59; SILVEIRA, Renato de Mello Jorge. Fundamentos da..., cit., pp. 372-373; BECHARA, Ana Elisa Liberatore Silva. Da teoria..., cit., pp. 328-340. Para esta última autora, não haveria maior dificuldade teórica em se delimitar um bem jurídico na hipótese, inclusive a partir de uma visão antropocêntrica, voltada à proteção da relação geral mantida entre os homens e animais; todavia, para além da identificação de um bem jurídico como critério de legitimação do tipo penal, segundo entende, devese perquirir acerca de outros critérios, como o atendimento aos princípios fundamentais penais, caso da intervenção mínima. Nesse sentido, sinaliza que talvez seja melhor ao ramo administrativo controlar o setor. BECHARA, Ana Elisa Liberatore Silva. Da teoria..., cit., pp. 339-340.

${ }^{167}$ HASSEMER, Winfried \& MUÑOZ CONDE, Francisco. Introducción a la criminología y al derecho penal. Valenci: Tirant lo Blanch, 1989, p. 105 (tradução livre). Cf., ainda, HASSEMER, Winfried.¿Puede Haber..., cit., p. 104 e passim. 
construção normativa, sendo objeto da escolha do legislador enquanto valor digno de tutela penal ${ }^{168}$.

Isto não significa que a legislação penal deva se mostrar impermeável às mudanças sociais ${ }^{169}$, fruto da sociedade altamente complexa e evoluída de nossos dias, com feições pós-industriais. O Direito é um meio racional de enfrentamento de desafios humanos decorrentes da convivência intersubjetiva.

Nesse sentido, novos interesses podem surgir e ser tutelados pelo Direito Penal. Todavia, o respeito a parâmetros claros e seguros para delimitação de seus contornos, como o conseguido por meio da noção de bem jurídico, é essencial para sua legitimidade.

Insta observar, sem embargo, com escora em JUAREZ TAVARES, mormente porque o tema objeto de análise do presente trabalho refere-se a especificamente a normas penais de cunho econômico, que bem jurídico não se confunde com função:

\begin{abstract}
A necessária vinculação de um bem jurídico estatal à sua origem e finalidade pessoal é uma garantia do indivíduo de que sua liberdade não será molestada por mera adoção de políticas públicas, no âmbito administrativo, econômico ou social, ou por finalidades eleitoreiras. Será preciso demonstrar, para tornar válida a eleição desta categoria de bem jurídico, que sua lesão signifique um dano igualmente à pessoa e às suas condições sociais. Por isso se deve descartar da noção de bem jurídico a noção de função, que encerra atividades administrativas do estado, referentes ao controle sobre determinado setor da vida de relação ou de seu próprio organismo ${ }^{170}$.
\end{abstract}

Dessa forma, o referencial ao indivíduo, no sentido de proteção de suas essenciais condições de vida numa sociedade estruturada sobre a base da liberdade humana, é a justificação de uma norma penal ${ }^{171}$. Também aos interesses supra-individuais

\footnotetext{
${ }^{168}$ REALE JÚNIOR, Miguel. Instituições de..., cit., p. 28.

${ }^{169}$ No mesmo sentido, e.g., COSTA, Helena Regina Lobo da. Proteção penal..., cit., p. 15.

170 TAVARES, Juarez. Teoria do..., cit., pp. 203-204. Analisando o pensamento de TAVARES, afirma BECHARA: “(...) A função não possui, desse modo, significado autônomo, consistindo em uma relação derivada de variáveis correspondentes a pontos referenciais de algo, sem implicarem por si um valor ou interesse". BECHARA, Ana Elisa Liberatore Silva. Da teoria ..., cit., p. 235. Sobre o tema, cf. também, v.g.: MANES, Vittorio. Il principio..., cit., p. 95 e ss.

${ }^{171}$ BECHARA, Ana Elisa L. Silva. O rendimento da..., cit., p. 26.
} 
deve haver uma interpretação teleológica voltada à identificação do referente individual ${ }^{172}$, o qual, todavia, cumpre frisar, não necessita ser imediato na estrutura do tipo penal ${ }^{173}$.

Esta a premissa básica a orientar o presente estudo ${ }^{174}$, não se concebendo um tipo penal carente de bem jurídico, seja este de cunho individual ou supra-individual ${ }^{175}$. Qualquer tentativa de reconhecimento de legitimidade de uma criminalização econômica como todas as demais - deve, a priori, identificar o bem jurídico penalmente tutelado ${ }^{176}$.

\subsection{Aproximação ao conceito de ordem econômica}

Para a identificação do bem jurídico a merecer a tutela penal na seara da delinquiência econômica, a dogmática penal há de considerar, inicialmente, para fins de aferição de eventuais pontos de contato, noções de Direito Econômico ${ }^{177}$. Este, segundo FÁBIO KONDER COMPARATO, é

(...) o conjunto das técnicas jurídicas de que lança mão o Estado contemporâneo na realização de sua política econômica. Ele constitui assim a disciplina normativa da ação estatal sobre as estruturas do sistema econômico, seja este centralizado ou descentralizado ${ }^{178}$.

O conceito de Direito Econômico, consoante observa MANOEL PEDRO PIMENTEL ${ }^{179}$, enfatiza a idéia de intervenção estatal com vistas à constituição de um sistema normativo destinado a regulamentar a realização da política econômica adotada. Há que se observar, assim, que a idéia central a dotar de sentido este ramo do Direito é a

${ }^{172}$ Neste exato sentido é o entendimento de ANA ELISA LIBERATORE SILVA BECHARA, aqui adotado: “(...) é importante destacar que, a partir do entendimento dos bens jurídicos supraindividuais como interesses coletivos dotados de referente individual, na qualificação de um comportamento como delito sempre será necessário interpretar o tipo penal teleologicamente, isto é, em atenção a esse fim, e não formalmente, sem que se possa verificar a existência de uma efetiva afetação da convivência social". BECHARA, Ana Elisa Liberatore Silva. Da teoria..., cit., p. 235.

${ }^{173}$ BECHARA, Ana Elisa Liberatore Silva. Da teoria..., cit., p. 236.

${ }^{174}$ De modo similar, p.ex.: FERRARI, Eduardo Reale. Legislação penal..., cit., p. 260.

175 Sobre o tema dos bens jurídicos difusos como objeto de proteção penal, cf., dentre outros, o aprofundado estudo de SILVEIRA, Renato de Mello Jorge. Direito penal supra-individual..., cit., p. 56 e ss.

176 "Partindo do pressuposto que não há sentido a legiferação penal sem a tutela a um bem jurídico, imprescindível restará saber qual o valor de tutela nos crimes econômicos, tendo como base de percepção os conceitos de dignidade penal e carência de sanção criminal”. FERRARI, Eduardo Reale. Legislação penal..., cit., p. 260.

${ }^{177}$ PIMENTEL, Manoel Pedro. Direito penal..., cit., p. 6.

${ }^{178}$ Apud PIMENTEL, Manoel Pedro. Direito penal..., cit., p. 8.

${ }^{179}$ PIMENTEL, Manoel Pedro. Direito penal..., cit., p. 9. 
ordenação, ou sistematização, do relacionamento das operações de natureza econômica, ou seja, a ordem econômica ${ }^{180}$.

Note-se ainda que o ideário inicial de Direito Econômico e, do mesmo modo, de Direito Penal Econômico, liga-se ao contexto de intervencionismo do Estado na economia, o que encontra nascedouro quando da $1^{\text {a }}$ Grande Guerra mundial, intensifica-se sobremodo durante o período subseqüente ao da crise de $1929^{181}$ e, por fim, consolida-se após a $2^{\mathrm{a}}$ Grande Guerra ${ }^{182}$. A concepção de regulação, ou ordenação, econômica encontra lastro, dessarte, em momentos de crise da economia.

O Direito Penal, neste diapasão, encontra-se inserido dentro de uma idéia geral de ordem econômica, ordem socioeconômica ou modelo econômico ${ }^{183}$. Todavia, tendo em vista que o gravoso ramo jurídico-penal é a ultima ratio na proteção de valores fundamentais à convivência social, não pode a compreensão de ordem econômica em seu âmbito identificar-se com uma simples particular forma de intervenção estatal na economia $^{184}$.

\footnotetext{
${ }^{180}$ PIMENTEL, Manoel Pedro. Direito penal..., cit., p. 9.

${ }^{181}$ Para se ter uma exata dimensão da influência da Grande Depressão nos ideais de intervencionismo estatal na economia, há que se lembrar que a encíclica papal Quadragesimo Anno, de 1931, exortou a regulamentação dos mercados baseada nos princípios cristãos.

${ }^{182}$ SILVEIRA, Renato de Mello Jorge. Direito penal econômico..., cit., pp. 20-21 e 64-65.

${ }^{183}$ Tais expressões serão utilizadas como sinônimas no presente estudo - embora "ordem econômica" seja a mais empregada, inclusive por força, no caso brasileiro, de influência do texto constitucional -, pois todas designam genericamente um conjunto de princípios e regras que disciplinam determinada área da vida social, qual seja, no caso, a das relações econômicas. Apontando, todavia, a ambigüidade do termo ordem econômica, seu histórico e alcance, cf. GRAU, Eros Roberto. A ordem..., cit., p. 60 e ss. Ainda, este autor diferencia a terminologia referida, a saber: "Sistema econômico como conjunto coerente de instituições jurídicas e sociais, de conformidade com as quais se realiza o modo de produção e a forma de repartição do produto econômico em uma determinada sociedade. Modelo econômico como configuração peculiar assumida pela ordem econômica (mundo do ser), afetada por determinado regime econômico (...)". GRAU, Eros Roberto. A ordem..., cit., pp. 192-193, nota 14 (itálicos originais).

${ }^{184}$ CERVINI, Raúl. Derecho penal económico democrático: hacia una perspectiva integrada. In: Direito penal econômico: análise contemporânea. VILARDI, Celso Sanchez; PEREIRA, Flávia Rahal Bresser \& DIAS NETO, Theodomiro (Coords.). São Paulo: Saraiva, 2009, p. 5 e ss. Em sentido contrário ao exposto, v.g., cf. VENTURA GONZÁLEZ: “(...) sem prejuízo de que o delito econômico afete interesses de particulares, o certo é que afeta fundamentalmente a política intervencionista no econômico-social, que todos os Estados contemporâneos se viram obrigados a adotar em menor ou maior medida, como consequiência da insegurança e desajuste próprio de nosso tempo. O Direito Econômico é o direito da economia organizada e a organização se realiza em função da Ordem Pública Econômica. Por isso a Ordem Pública Econômica é o Bem Jurídico Tutelado". GONZÁLEZ, Ventura. Nociones generales sobre derecho penal económico. Mendoza: Ediciones Jurídicas Cuyo, 1998, p. 29 (tradução livre).
} 
Assim, afastando-se dos contornos próprios do Direito Econômico, a idéiaforça capaz de dotar de sentido material o Direito Penal Econômico é a de imprescindível meio de tutela de um objeto jurídico que tem em vista a segurança e a regularidade da estrutura econômica de um determinado contexto social ${ }^{185}$.

Sem esta última delimitação conceitual, mas apontando no sentido descrito quanto ao objeto jurídico do Direito Penal Econômico, o bem jurídico ordem econômica foi identificado pelo XIII Congresso da Associação Internacional de Direito Penal (Cairo, 1984) ${ }^{186}$, assim como o fora doutrinariamente em nosso país nos umbrais da década de setenta do século passado por PIMENTEL ${ }^{187}$.

Insurgindo-se contra esse entendimento, todavia, CARLOS PÉREZ DEL VALLE afirma que o critério classificatório de designação de um bem jurídico ou interesse tutelado de ordem econômica proporciona certo grau de confusão no momento de encontrar elementos próprios dos delitos que se desejem classificar dentro do estudo do Direito Penal Econômico, pois às vezes resultaria preferível simplesmente a designação do específico objeto de ataque (como "propriedade industrial") ou ainda a referência do nomen iuris do fato punível concreto ("alteração de preços em concorrências públicas”) 188.

Curiosamente, todavia, a seguir, o autor aproxima-se da idéia que procurou refutar ao, com lastro em HARRO OTTO, conceituar que

\footnotetext{
${ }^{185}$ Em sentido similar, ENRIQUE AFTALIÓN entende que o bem jurídico tutelado nos delitos econômicos é a economia nacional em seu conjunto. Apud GONZÁLEZ, Ventura. Nociones generales..., cit., pp. 31-32.

${ }^{186}$ Dentro da seção II ("Concept and principles of economic and business criminal law, including consumer protection") do documento firmado, fixou-se: “Terminology. 4. The term 'economic penal law' is here understood to encompass offenses against the economic order. The term 'business penal law' refers to offenses involving private or public enterprises. Both are closely interrelated in the sense that the offenses violate legal regulations which organize and protect economic and business life. Protected interests. 5. In most cases, the use of penal law in this field is concerned with the protection of collective, not only individual, interest. Most of these collective interests, being particularly complex and diffuse, are more difficult to identify and defend than individual interests. Therefore, there is a special need to protect these collective interests. Their protection by penal law should be assumed by the Penal Code". INTERNACIONAL ASSOCIATION OF PENAL LAW. Eletronic Review of the International Association of Penal Law. Referência: e-RIAPL $2007 . \quad$ Disponível em: $<$ http://www.penal.org/pdf/ReAIDP2007/RICPL\%201984.pdf>. Acesso em: 12 ago. 2009.

${ }^{187}$ PIMENTEL, Manoel Pedro. Direito penal..., cit., p. 9.

${ }^{188}$ PÉREZ DEL VALLE, Carlos. Introducción al derecho penal económico. In: BACIGALUPO, Enrique (Dir.). Derecho penal económico. Buenos Aires: Hamurabi, 2004, p. 34.
} 
(...) são delitos econômicos aqueles comportamentos descritos nas leis que lesionam a confiança na ordem econômica vigente com caráter geral ou em alguma de suas instituições em particular e, portanto, põem em perigo a própria existência e as formas de atividade dessa ordem econômica ${ }^{189}$.

Esta última é a noção que aqui se acolhe, entendendo-se, ao revés, que a idéia de uma enumeração de situações é vilipendiadora do caráter científico do Direito Penal, incapaz de dotar de sentido o subsistema do Direito Penal Econômico.

De outra parte, também CARLOS MARTÍNEZ-BUJÁN PÉREZ ${ }^{190}$ e JUAN M. TERRADILLOS BASOCO ${ }^{191}$ questionam a idéia de que o Direito Penal Econômico visaria simplesmente tutelar diretamente a ordem socioeconômica ${ }^{192}$. Afastam-se estes autores espanhóis, portanto, da identificação do bem jurídico na hipótese como exclusivamente atrelado à noção de atividade interventora e reguladora do Estado na economia, por entender que haveria um formalismo alheio a qualquer lesividade ${ }^{193}$.

A solução mais adequada estaria assim, conforme entendem, na identificação de um bem jurídico mediato e outro imediato. O primeiro seria necessariamente de cunho supra-individual ou espiritualizado - a idéia de ordem socioeconômica -, enquanto que o último poderia revelar caráter individual ou mesmo supra-individual, relacionado que estaria com o interesse imediatamente protegido, a ser considerado caso a caso:

(...) a concepção ampla aqui propugnada permite estender a noção a delitos que não possuem um bem jurídico supra-individual como objeto imediato de proteção, englobando também delitos que tutelam diretamente um bem jurídico individual de conteúdo econômico, mas com a particularidade de que se orientam à proteção de um bem jurídico mediato supra-individual, ou se preferir, que se caracterizam pelo fato de que entre os motivos ou razões que influem na decisão do legislador de outorgar-lhes dignidade penal se encontra a

\footnotetext{
${ }^{189}$ PÉREZ DEL VALLE, Carlos. Introducción..., cit., p. 35 (tradução livre).

190 MARTÍNEZ-BUJÁN PÉREZ, Carlos. Derecho penal económico y de la empresa. Parte general. Valencia: Tirant lo Blanch, 2007, pp. 119-120, 158 e passim.

191 "Contrariamente à tradicional criminalidade patrimonial, os delitos contra a ordem socioeconômica revelam bens jurídicos imateriais, institucionalizados ou espiritualizados, de titularidade social ou coletiva. Este conjunto de bens jurídicos não deve ser identificado com a 'atividade interventora e reguladora do Estado na economia', como sugere o conceito de Direito Penal econômico que a doutrina espanhola vem denominando 'estrito' (...)". TERRADILLOS BASOCO, Juan M. Sistema penal y delitos contra el orden socioeconómico. Consideraciones introductorias. In: DE LA CUESTA AGUADO, Paz Mercedes et all. Derecho penal económico. Mendoza: Ediciones Jurídicas Cuyo, 2003, p. 61 (tradução livre).

${ }^{192}$ Entendimento, não obstante, majoritário na doutrina espanhola, conforme reconhecido pelo último autor citado.

${ }^{193}$ TERRADILLOS BASOCO, Juan M. Sistema penal..., cit., p. 61.
} 
existência de interesses coletivos ou supra-individuais necessários para um correto funcionamento do sistema econômico imperante (p. ex., os delitos contra a propriedade industrial, delitos de concorrência desleal, a maior parte dos delitos societários) ${ }^{194}$.

O engenhoso pensamento, interessante do ponto de vista didático, sem embargo, ao procurar negar a existência de um bem jurídico atrelado à sistematização econômica, também o reafirma, na medida em que o classifica como categoria mediata, e, desta feita, teleológica, pouco aclarando da situação com o referido interesse casuístico imediato. Ademais, ao procurar distinguir o delito econômico do meramente patrimonial, o entendimento é obscuro e confunde o intérprete, pois certamente no crime patrimonial não se pode negar o interesse mediato do Estado, de algum modo, na manutenção da ordem econômica vigente ${ }^{195}$.

Ante o exposto, a ordem socioeconômica afigura-se, notadamente, como o interesse supra-individual penalmente tutelado pelo Direito Penal Econômico, focando-se a confiança, ou expectativa normativa, socialmente depositada no tráfico econômico, capaz de lesionar ou pôr em perigo a vida econômica no geral ${ }^{196}$, ou seja, a estrutura econômica ${ }^{197}$ da sociedade, representativa de um valor decorrente da vida individual e social, indispensável à sua manutenção e ao seu livre desenvolvimento ${ }^{198}$. Esta última compreensão é, assim, a que, de um lado, permite a concreção de sentido do bem jurídico

\footnotetext{
${ }^{194}$ MARTÍNEZ-BUJÁN PÉREZ, Carlos. Derecho penal..., cit., p. 119 (tradução livre).

195 Contrariamente ao sentido aqui defendido: "Definido do modo apontado o primeiro critério individualizador, convém advertir que, conseqüentemente, restariam de plano excluídos da categoria sócioeconômica todos aqueles delitos patrimoniais clássicos que conceitualmente não incorporam de forma indefectível entre seus elementos básicos uma afetação - sequer mediata - à ordem econômica (v.g., estelionato, apropriação indébita, danos), apesar de no caso concreto poder-se acreditar que sua execução ensejaria uma certa afetação à ordem sócio-econômica em face da relevante magnitude do prejuízo produzido". MARTÍNEZ-BUJÁN PÉREZ, Carlos. Derecho penal..., cit., p. 120 (tradução livre).

${ }^{196}$ TIEDEMANN, Klaus. Poder económico..., cit., p. 11.

${ }^{197}$ SILVEIRA, Renato de Mello Jorge. Direito penal econômico..., cit., p. 32.

${ }^{198}$ Cf. TAVARES, Juarez. Teoria do..., cit., p. 202. Pretende-se com a parte final da frase frisar, com escora neste último autor, que uma norma penal econômica deve tutelar um bem jurídico de dignidade penal - assim, com necessária referência às condições essenciais para a vida social pacífica dos indivíduos - e não servir a uma mera função estatal, a qual “(...) encerra atividades administrativas do Estado, referentes ao controle sobre determinado setor da vida de relação ou de seu próprio organismo". TAVARES, Juarez. Teoria do..., cit., p. 202. O Direito Penal, desse modo, não serve à mera adoção de políticas públicas econômicas. Uma norma lastreada neste último aspecto será ilegítima.
} 
na hipótese, e, de outro, afastar-se a mera lesão patrimonial individual, típica, e.g., do furto ou do roubo, da delinqüência econômica propriamente dita ${ }^{199}$.

Neste sentido, o conceito Direito Penal Econômico refere-se diretamente à tutela do justo equilíbrio da produção, circulação e distribuição de riquezas entre os cidadãos $^{200}$, consubstanciando-se num controle social do mercado conforme o modelo econômico adotado. Por esta razão, diferencia-se o Direito Penal Econômico, e.g., do Direito Penal Tributário ${ }^{201}$ e do Direito Penal Ambiental, nos quais o apontado referencial, ainda que existente, é indireto, aproximando-se concretamente das infrações contra a livre concorrência, contra o mercado de capitais e contra as relações de consumo - os quais, por sua vez, estão relacionados pelo fato do consumidor ser o beneficiário último da concorrência correta num mercado livre ${ }^{202}$.

\subsection{A confiança como elemento necessário para a reprodução e circulação da riqueza}

Ao procurar tutelar o interesse difuso concernente no sistema econômico, consoante afirmado, o Direito Penal Econômico é utilizado com vistas a resguardar a

\footnotetext{
199 Ainda que os crimes patrimoniais mencionados possam atentar contra a propriedade privada, um dos princípios fundamentais da ordem econômica, não se acata aqui a já aventada tese de TIEDEMANN, ou seja, a idéia de uma criminalidade econômica em sentido amplo. Cf. TIEDEMANN, Klaus. Poder económico..., cit., p. 12.

${ }^{200}$ Cf. ARAUJO JÚNIOR, João Marcello de. Dos crimes contra a ordem econômica. São Paulo: Revista dos Tribunais, 1995, p. 36.

${ }^{201}$ Não obstante a exclusão dos crimes tributários da idéia de Direito Penal Econômico, é conhecida a sua função de extrafiscalidade e conseqüente intervenção estatal na vida econômica e social por meio da tributação. Aliás, esta função hoje em dia vem ganhando proporções cada vez maiores, porém, assume-se aqui a premissa de que a primordial função tributária é a arrecadação e custeio do Estado. Explicando tal aspecto, escreve NOGUEIRA: “(...) É, pois, no campo da Receita, que o Estado transforma e moderniza seus métodos de ingerência. $\mathrm{O}$ imposto deixa de ser conceituado como exclusivamente destinado a cobrir as necessidades financeiras do Estado. É também, conforme o caso e o poder tributante, utilizado como instrumento de intervenção e regulamentação de atividades. É o fenômeno que hoje se agiganta com a natureza extrafiscal do imposto". NOGUEIRA, Ruy Barbosa. Curso de direito tributário. São Paulo: Saraiva, 1995, pp. 184-185.

${ }^{202}$ Sobre este tema, cf. REALE JÚNIOR, Miguel. Concorrência desleal e interesse difuso no direito brasileiro. Revista de Direito Penal e Criminologia, Rio de Janeiro, n. 33, 1982, pp. 159-169. Diferenciando o delito econômico do fiscal, por exemplo, na doutrina pátria, cf. PIMENTEL, Manoel Pedro. Direito penal..., cit., p. 17 e ss. e pp. 109-110. A respeito do tema, com visão diversa, cf., e.g., FERRARI: “(...) em uma visão estrita, a ordem econômica deve tutelar a regulação jurídica do intervencionismo estatal na economia de uma nação, incluindo como objeto de proteção o próprio interesse do Estado, suscetível de concreção particularizada, dos quais exemplos são as infrações monetárias; as transações com o exterior; o delito fiscal, a liberdade da empresa no marco da economia do mercado, a livre concorrência empresarial, incluindo-se dentro desse conceito os interesses coletivos, dos quais exemplos são o consumo, o meio ambiente, dentre outros”. FERRARI, Eduardo Reale. Legislação penal..., cit., pp. 260-261.
} 
segurança e a regularidade da estrutura, ou base, econômica da sociedade, acautelando, enfim, a ordem econômica, tudo com vistas a evitar o dano à economia nacional em seu conjunto.

O homem, ser social por natureza, acaba se relacionando e interagindo economicamente $^{203}$, sendo esta uma das características fundamentais da sociedade forjada desde fins do período medieval. Partindo da concepção sociológica de LUHMANN, em especial quanto à formação e estruturação das expectativas sociais ${ }^{204}$, ter-se-ia, pois, por justificada, em termos, a ingerência do Direito Penal na esfera econômica ${ }^{205}$.

Neste sentido, o abuso na confiança socialmente depositada na reprodução e circulação da riqueza é conduta referencial típica na delinqüência econômica. A contrario sensu, observa-se que a norma penal econômica visa consagrar a confiança social depositada na intersubjetividade negocial do modo de produção capitalista vigente.

No exato sentido descrito é a leitura crítica de SALVADOR NETTO:

(...) O direito penal, portanto, quando cria novos modelos típicos não contradiz sua função burguesa, apenas a adapta à nova realidade da produção social da riqueza, com a qual é, em última instância, condicionado. (...) A sociedade de risco criou a tecnologia que gerou o seqüestro dos homens pela sua própria obra. Surge o mercado mundo e com ele as elementares intocáveis e impassíveis de qualquer crítica; a concorrência, o consumo de larga escala e alucinado, o sistema financeiro internacional, os bolsões de investimento, a repleta volatilidade da riqueza. Todas estas novas realidades se para alguns trazem benefícios e circulação de divisas, inegavelmente também se apercebeu da necessidade de confiança, disciplina, cumprimento das regras do jogo, e, exatamente neste ponto, entra a dinâmica do direito penal, sua tipificação gerencial e, como afirma BERGALLI, sua eficiência ${ }^{206}$.

203 SILVEIRA, Renato de Mello Jorge. Direito penal econômico..., cit., p. 29.

${ }^{204}$ LUHMANN, Niklas. Sociologia do direito I. Trad. Gustavo Bayer. Rio de Janeiro: Tempo Brasileiro, 1983, p. 53 e ss. e passim. Para uma síntese do pensamento de LUHMANN, e.g., cf.: GARCÍA AMADO, Juan Antonio. La filosofia del derecho de Habermas y Luhmann. Bogotá: Universidad Externado de Colombia, 1999, p. 162 e ss.; BÜLLESBACH, Alfred. Princípios de teoria dos sistemas. In: KAUFMANN, Arthur \& HASSEMER, Winfried (Orgs.). Introdução à filosofia do direito e à teoria do direito contemporâneas. Trad. Marcos Keel e Manuel Seca de Oliveira. Lisboa: Fundação Calouste Gulbenkian, 2002 , p. 409 e ss. Sobre o tema, vide ainda item "2.3", infra.

205 KAUFMANN, Arthur. Filosofía del derecho. Trad. Luis Villar Borda y Ana María Montoya. Bogotá: Universidad Externado de Colombia, 2002, p. 336; SILVEIRA, Renato de Mello Jorge. Direito penal econômico..., cit., p. 29; CAVERO GARCÍA, Percy. Derecho penal..., cit., p. 283 e ss.

${ }^{206}$ SALVADOR NETTO, Alamiro Velludo. Tipicidade penal e sociedade de risco. São Paulo: Quartier Latin, 2006, pp. 103-104. Diversamente, mas sem maior aprofundamento, entendendo que o Direito Penal 
De fato, um sistema monetarizado de livre mercado, com ressaltado caráter financeiro e creditício, necessita fundamentalmente da confiança para seu regular funcionamento. Neste sentido, frise-se que a funcionalidade da economia que o Estado visa garantir necessita, antes de tudo, da confiabilidade dos agentes econômicos, sob pena de retumbante fracasso.

É por essa razão que a criminalização econômica volta-se, por exemplo, a interesses imediatos como o resguardo de informações privilegiadas no mercado mobiliário (insider trading), a manutenção da livre concorrência ou a assecuração da veracidade das informações prestadas aos consumidores de um produto determinado, sem o que se compromete a confiança dos agentes econômicos na realidade negocial concreta.

No mesmo sentido, segundo BERNARDO FEIJOO SÁNCHEZ, a finalidade primacial da sanção penal na espécie é preventiva geral positiva:

(...) Cabe assinalar, ademais, que enquanto nos primeiros trabalhos sobre os fins preventivos do Direito penal econômico primava claramente a prevenção geral negativa (idéia que continua sendo básica na política criminal dos países anglosaxões), pouco a pouco se vai abrindo passo a uma concepção da prevenção geral a qual, mais que a intimidação, busca a melhor maneira de estabilizar as normas essenciais da vida econômica, evitando a anomia e a pura lei do mais forte, mantendo com isto a confiança em um funcionamento do sistema econômico de acordo com o prescrito pelo Direito ${ }^{207}$.

Destarte, a confiança como elemento necessário para a reprodução e circulação da riqueza é um importante marco valorativo ético-social capaz de particularizar e, de certo modo, justificar, a infração penal econômica. Cuida-se então de um adicional elemento normativo a ser aferido na análise do tipo penal econômico ${ }^{208}$.

Econômico viria a romper com a ideologia que tende a privilegiar os interesses das classes hegemônicas, cf. ARAUJO JÚNIOR, João Marcello. Dos crimes..., cit., pp. 35-36.

${ }^{207}$ FEIJOO SÁNCHEZ, Bernardo. Sanciones penales y prevención de delitos socioeconómicos. In: BOIX REIG, Javier (Dir.) \& LLORIA GARCIA, Paz (Coord.). Diccionario de derecho penal económico. Madrid: Iustel, 2008, p. 844 (tradução livre).

${ }^{208}$ CAVERO GARCÍA, Percy. Derecho penal..., cit., pp. 284-285. Afirmando que a perspectiva acerca da confiança difere consoante uma análise criminológica ou dogmática, segundo o autor peruano "(...) em Direito penal, trata-se de um conceito normativo que responde não a considerações empíricas, mas que entende que a prática de um delito constitui um abalo da confiança nas expectativas garantidas normativamente, independentemente se no caso concreto ocorreu um abalo da confiança nos afetados. A 
Por esta linha de raciocínio, há que se destacar que referido parâmetro representa, outrossim, menos um argumento capaz de fundamentar exclusivamente o expansionismo penal econômico, mas sim muito mais um marcante elemento crítico, ou seja, delimitador, de uma citada construção tipificadora. Consubstancia-se, assim, em um elemento valorativo a ser considerado na identificação do bem jurídico ordem econômica. A compreensão aqui adotada da confiança como elemento limitador da incidência penal, ou seja, de uma abordagem garantista a seu respeito, com vistas à constatação de legitimidade do delito econômico, dessa maneira, distancia-se, em certa medida, das perspectivas de, por exemplo, citados autores de língua espanhola FEIJOO SÁNCHEZ e CAVERO GARCÍA. Pretende-se com isso uma maior clareza na identificação de um conceito material de infração penal econômica.

Em outras palavras, mister se faz esclarecer neste ponto que o vilipêndio da confiabilidade econômica mostra-se pressuposto, mas não razão suficiente, para a criminalização em foco, devendo ser apurada uma sequiência de outros critérios dogmáticos e político-criminais pertinentes, consoante se cuidará ao longo da presente investigação científica. Neste diapasão, quando a conduta vedada não demonstrar sequer em tese possibilidade de abalo de tal confiança, ilegítima será a intervenção penal ${ }^{209}$.

\subsection{A experiência penal de garantia do sistema econômico na legislação brasileira atual}

O intervencionismo estatal na economia brasileira, como citado, origina-se na Constituição de $1934^{210}$, tendo havido a primeira tipificação infracional penal correlata em

reestabilização da confiança na norma tampouco requer, portanto, que a pena imposta devolva a confiança fática no sistema econômico. Está claro que os conceitos normativos não podem sustentar-se sem uma base fática mínima (condições de existência), mas deve restar claro que a análise jurídica de cada caso concreto não pode reverberar ao terreno do empírico. Enquanto não se demonstre categoricamente que os efeitos empíricos supostos não se produziram, as disciplinas normativas estão autorizadas a supô-los". CAVERO GARCÍA, Percy. Derecho penal..., cit., pp. 284-285 (tradução livre).

${ }^{209}$ A questão da mensuração de referido abalo será objeto de investigação do capítulo 2.

${ }^{210}$ Artigo 115 e ss. Como demonstrativo da política então adotada, veja-se o caput do artigo 115 da Carta de 1934: "A ordem econômica deve ser organizada conforme os princípios da Justiça e as necessidades da vida nacional, de modo que possibilite a todos existência digna. Dentro desses limites, é garantida a liberdade econômica". 
1938, com o Decreto-Lei $n^{\circ} 869^{211}$, que tutelava a economia popular ${ }^{212}$. Atualmente, a legislação penal brasileira em matéria de delinqüência econômica - como, ademais, no geral $^{213}$ - revela os característicos do expansionismo, tutela antecipatória, falta de técnica ${ }^{214}$

${ }^{211}$ A legislação fixava como tipos penais: "Art. $2^{\circ}$. São crimes dessa natureza: I, destruir ou inutilizar, intencionalmente e sem autorização legal, com o fim de determinar alta de preços, em proveito próprio ou de terceiro, matérias primas ou produtos necessários ao consumo do povo; II, abandonar ou fazer abandonar lavouras ou plantações, suspender ou fazer suspender a atividade de fábricas, usinas ou quaisquer estabelecimentos de produção, ou meios de transporte, mediante indenização paga pela desistência da competição; III, promover ou participar de consórcio, convênio, ajuste, aliança ou fusão de capitais, com o fim de impedir ou dificultar, para o efeito de aumento arbitrário de lucros, a concorrência em matéria de produção, transporte ou comércio; IV, reter ou açambarcar matérias primas, meios de produção ou produtos necessários ao consumo do povo, com o fim de dominar o mercado em qualquer ponto do país e provocar a alta dos preços; V, vender mercadorias abaixo do preço de custo com o fim de impedir a concorrência; VI, provocar a alta ou baixa de preços, títulos públicos, valores ou salários por meio de notícias falsas, operações fictícias ou qualquer ouro artifício; VII, dar indicações ou fazer afirmações falsas em prospectos ou anúncios, para o fim de subscrição, compra ou venda de títulos, ações ou quotas; VIII, exercer funções de direção, administração ou gerência de mais de uma empresa ou sociedade do mesmo ramo de indústria ou comércio com o fim de impedir ou dificultar a concorrência; IX, gerir fraudulentamente ou temerariamente bancos ou estabelecimentos bancários, ou de capitalização; sociedades de seguros, pecúlios ou pensões vitalícias; sociedades para empréstimos ou financiamento de construções e de vendas de imóveis a prestações, com ou sem sorteio ou preferência por meio de pontos ou quotas; caixas econômicas; caixas Raiffeisen; caixas mútuas, de beneficência, socorros ou empréstimos; caixas de pecúlio, pensão e aposentadoria; caixas construtoras; cooperativas; sociedades de economia coletiva, levando-as à falência ou à insolvência, ou não cumprindo qualquer das cláusulas contratuais com prejuízo dos interessados; $\mathrm{X}$, fraudar de qualquer modo escriturações, lançamentos, registros, relatórios, pareceres e outras informações devidas a sócios de sociedades civís ou comerciais, em que o capital seja fracionado em ações ou quotas de valor nominativo igual ou inferior a 1:000\$000, com o fim de sonegar lucros, dividendos, percentagens, rateios ou bonificações, ou de desfalcar ou desviar fundos de reserva ou reservas técnicas. Pena: prisão celular de 2 a 10 anos e multa de 10:000\$000 a 50:000\$000. Art. $3^{\circ}$. São ainda crimes contra a economia popular, sua guarda e seu emprego: I, celebrar ajuste para impor determinado preço de revenda ou exigir do comprador que não compre de outro vendedor; II, transgredir tabelas oficiais de preços de mercadorias; IlI, obter ou tentar obter ganhos ilícitos, em detrimento do povo ou de número indeterminado de pessoas, mediante especulações ou processos fraudulentos ("bola de neve", "cadeias", "pichardismo", ete.); IV, violar contrato de venda a prestações, fraudando sorteios ou deixando de entregar a coisa vendida, sem devolução das prestações pagas, ou descontar destas, nas vendas com reserva de domínio, quando o contrato for rescindido por culpa do comprador, quantia maior do que a correspondente à depreciação do objeto; $\mathrm{V}$, fraudar pesos ou medidas padronizados em lei ou regulamento; possuí-los ou detê-los, para efeitos de comércio, sabendo estarem fraudados. Pena: prisão celular de 6 meses a 2 anos e multa de 2:00\$000 a 10:000\$000. Art. $4^{\circ}$. Constitue crime da mesma natureza a usura pecuniária ou real, assim se considerando: a) cobrar juros superiores à taxa permitida por lei, ou comissão ou desconto, fixo ou percentual, sobre a quantia mutuada, alem daquela taxa; b) obter ou estipular, em qualquer contrato, abusando da premente necessidade, inexperiência ou leviandade da outra parte, lucro patrimonial que exceda o quinto do valor corrente ou justo da prestação feita ou prometida. Pena: 6 meses a 2 anos de prisão celular e multa de 2:000\$000 a 10:000\$000 (...)".

${ }^{212}$ SILVEIRA, Renato de Mello Jorge. Direito penal econômico..., cit., p. 22. Embora, como lembra FERRARI, já em 1933 fixaram-se normas para repressão ao crime de usura. FERRARI, Eduardo Reale. Legislação penal..., cit., p. 255.

${ }^{213}$ SILVA SÁNCHEZ, Jesús-María. A expansão do direito penal - aspectos da política criminal nas sociedades pós-industriais. Trad. Luiz Otávio de Oliveira Rocha. São Paulo: Revista dos Tribunais, 2002, p. 23 e ss. Houve oportunidade de debruçar-se sobre o tema em investigações acadêmicas de mestrado, cf. SOUZA, Luciano Anderson de. Expansão do direito penal e globalização. São Paulo: Quartier Latin, 2007, p. 139 e passim.

${ }^{214}$ PIMENTEL, Manoel Pedro. Direito penal..., cit., p. 59. 
e, verdadeiramente, confusão. Há, em síntese, falta de sistematização e hipertrofia, consagrando-se um Direito Penal simbólico:

\begin{abstract}
A teoria da prevenção geral positiva é, portanto, uma teoria da função simbólica do direito penal, no sentido de que as funções indicadas se relacionam diretamente com a expressão dos valores assumidos pelo ordenamento e com a afirmação da validade das normas, confirmação esta simbólica e não empírica, por ser independente da quantidade de infrações e da sua redução. Assim sendo, a defesa dos bens jurídicos não pode ser considerada, segundo a teoria da prevenção-integração, como uma função principal das normas penais. Sob este ponto de vista, o direito penal não é tanto um instrumento de imposição da 'moral dominante', senão um meio eficaz de representação (simbólica) desta 215
\end{abstract}

Quanto à forma, referidas leis são editadas autonomamente, isto é, por meio de legislação penal especial ${ }^{216}$, como, por exemplo, as Leis $n^{\circ}$ s 7.492/86, 8.078/90, $8.137 / 90$ e $10.303 / 01$, dentre outras citadas supra ${ }^{217}$.

No geral, materialmente, misturam-se assuntos (caso, e.g., das Leis $\mathrm{n}^{\circ} \mathrm{s}$ 8.078/90, 8.137/90 e 8.884/94), erigem-se à categoria de crimes condutas pouco claras ou de grande complexidade e fixam-se penas desproporcionais. A forma tipificadora padrão é a de crimes de perigo abstrato, tipos abertos, tipos culposos e omissivos e normas penais em branco, estas últimas no mais das vezes a serem complementadas por normas administrativas.

${ }^{215}$ BARATTA, Alessandro. Funções instrumentais e simbólicas do direito penal. Lineamentos de uma teoria do bem jurídico. Trad. Ana Lúcia Sabadell. Revista Brasileira de Ciências Criminais, São Paulo, n. 5, jan./mar. 1994, pp. 21-22.

${ }^{216} \mathrm{O}$ que não representaria necessariamente algo negativo, dadas as peculiaridades do Direito Penal Econômico. A respeito, escrevem SILVEIRA e SALVADOR NETTO: "Fundamentalmente, pode-se afirmar que o Direito Penal Econômico guarda diferenças basilares do chamado Direito Penal nuclear. E isso, desde as suas primeiras linhas. Desde a sua formação típica, até as modalidades de apenação e quantidades de pena, muitas são as filigranas distintivas. Nele, os crimes de perigo abstrato se fazem bastante presentes, formando um verdadeiro Direito Penal de Perigo, já que se informa que não se poderia esperar a um efeito lesivo à ordem econômica defendida. Isso, contudo, não cria emergente proteção. De fato, a aparente falta de efetividade desta forma de repressão penal tem se posto como um dos maiores óbices de sua manutenção como forma de combate à criminalidade". SILVEIRA, Renato de Mello Jorge \& SALVADOR NETTO, Alamiro Velludo. A tutela penal..., cit., pp. 376-377. Defendendo um regramento apartado do Código Penal, em razão da mutabilidade ínsita ao Direito Penal Econômico, v. COSTA, José de Faria. Direito penal..., cit., p. 44.

${ }^{217}$ Sem prejuízo de excepcionais pontuais inserções no Código Penal (caso, e.g., dos artigos 168-A e 337-A do Código Penal) para aqueles que possuem uma visão ampla da matéria compreendida pelo Direito Penal Econômico. Cf., e.g., PRADO, Luiz Regis. Direito penal..., cit., passim. 
Dessa maneira, conforme se analisará infra, os princípios da legalidade e da lesividade são constantemente vilipendiados, convertendo-se o Direito Penal Econômico em mera legislação ordenacional, de interesses de determinada política estatal - econômica ou não -, isto é, de interesses administrativos. Tal quadro consagra ampla insegurança jurídica e dá lastro ao arbítrio, razões pelas quais se impõe o equacionamento da problemática.

\subsection{Problemas dogmáticos do Direito Penal Econômico}

O Direito Penal Econômico encontra dificuldades de efetividade, razão pela qual se pode formular contra ele contundentes críticas. Identificam-se duas ordens de problematização matizadoras de tais embaraços: uma de construção dogmática propriamente dita e outra político-criminal, influenciada e influenciadora da formulação anterior, de estruturação de um direito penal simbólico.

São inúmeros os desafios do cerceamento jurídico-criminal da atividade econômica, mormente na atualidade. Primeiramente, a própria dinamicidade deste empreendimento humano, em constante evolução e mutação com vistas ao lucro e à conquista de mercados em uma sociedade de livre comércio altamente complexa, ávida por novidades e ostentadora de perene renovação tecnológica, torna bastante árdua a tarefa regulatória $^{218}$.

Ademais, em face do mercado globalizado em constante ampliação, o horizonte da criminalidade econômica não se cinge às fronteiras dos Estados nacionais, sendo, isto sim, o mundo ${ }^{219}$. Neste diapasão, para além de vulneração prática de controle, sérios problemas de territorialidade da lei penal prejudicam sua aplicação ${ }^{220}$.

A obsolescência da norma diante do mutante colorido da engenhosidade laboral humana, da complexidade das específicas atividades econômicas de uma sociedade com modo de produção capitalista bastante evoluído, com enorme divisão de tarefas e

${ }^{218}$ PIMENTEL, Manoel Pedro. Direito penal..., cit., p. 31.

${ }^{219}$ COSTA, José de Faria. Direito penal..., cit., p. 87.

${ }^{220}$ COSTA, José de Faria. Direito penal..., cit., pp. 101-103. 
novas tecnologias ${ }^{221}$, do surgimento de novas práticas empresariais e novos produtos, dentre outros característicos, tornam já de antemão bastante pouco provável que o Direito Penal, com suas características de legalidade e taxatividade, cingindo-se a apenas estas duas fundamentais, seja capaz de oferecer reais resultados de prevenção e repressão de práticas econômicas socialmente nocivas.

Ademais, os princípios da livre iniciativa ${ }^{222}$, da livre concorrência ${ }^{223}$ e da autonomia da vontade incrementam a dificuldade de regulação jurídica (inclusive extrapenal) ainda mais, já que o próprio ordenamento autoriza, ou mesmo estimula, a constante evolução da atividade econômica. Os agentes econômicos buscam intensa e diuturnamente a exploração de novos mercados, a utilização de inéditas técnicas e práticas, a criação de novos produtos ou serviços, etc., tudo com vistas ao angariamento de maiores lucros. Essa a lógica de nosso sistema econômico.

Dessa maneira, cumpre observar que, se a realidade no geral sempre está à frente do Direito, especificamente no caso em foco há uma radicalização de tal característica, tendo em vista que a enorme dinâmica da factualidade econômica engendra um profundo abismo para com o Direito Penal de contornos liberais (reitere-se, que consagra os princípios da legalidade, taxatividade, etc., e, desta feita, não revela nem de longe um dinamismo similar). Para manter suas próprias características concernentemente

${ }^{221}$ COSTA, José de Faria. Direito penal..., cit., p. 88.

${ }^{222}$ Fixa o artigo 170 da Carta de 1988: “(...) a ordem econômica, fundada na valorização do trabalho humano e na livre iniciativa, tem por fim assegurar a todos a existência digna, conforme os ditames da justiça social (...)". Sobre a livre iniciativa, cf. GRAU: "Importa deixar bem vincado que a livre iniciativa é expressão de liberdade titulada não apenas pela empresa, mas também pelo trabalho. A Constituição, ao contemplar a livre iniciativa, a ela só opõe, ainda que não a exclua, a 'iniciativa do Estado'; não a privilegia, assim, como bem pertinente apenas à empresa. É que a livre iniciativa é um modo de expressão do trabalho, do trabalho livre como observa Miguel Reale Júnior - em uma sociedade livre e pluralista". GRAU, Eros Roberto. A ordem..., cit., p. 206. Sobre o tema, vide, ainda, e.g., COELHO, Inocêncio Mártires. Princípios da ordem econômica e financeira. In: MENDES, Gilmar Ferreira; COELHO, Inocêncio Mártires \& BRANCO, Paulo Gustavo Gonet. Curso de direito constitucional. São Paulo: Saraiva, 2009, p. 1409; FERRARI, Eduardo Reale. Legislação penal..., cit. pp. 259 e 302-303.

${ }^{223}$ Após, com base em REALE, sintetizar o conceito de livre iniciativa como "(...) livre eleição da atividade e dos meios de que se deve lançar mão na consecução da ação econômica”, REALE JÚNIOR diferencia o conceito de livre concorrência, que, por sua vez, é "“...) um modo de se desenrolar a atividade econômica, alçada à categoria de princípio, ao lado da propriedade privada e da função social. A livre concorrência significa que a atividade econômica, baseada na livre iniciativa, deve desenvolver-se segundo as leis do mercado, sem outros limites que não os estabelecidos na própria Constituição, como meio de impedir que a concorrência se transforme em abuso, em falta de correção, em deslealdade, em ganância". REALE JÚNIOR, Miguel. Casos de direito constitucional. São Paulo: Revista dos Tribunais, 1992, pp. 13 e 15, respectivamente. 
à delinqüência econômica, assim, o Direito Penal muitas vezes será ineficaz, uma vez que regulará condutas ultrapassadas pela realidade.

De outra sorte, conforme foi apontado acima, o delito econômico revela enorme problemática no que pertine à sua responsabilização, quer em termos de autoria, co-autoria ou participação ${ }^{224}$. Tal representa mais um grande desafio do tratamento penal da delinqüência econômica.

Consoante se pode depreender sem maiores dificuldades em face dos característicos do atual estágio do modo de produção capitalista, o empreendimento econômico hodierno de maior vulto é muito mais afeto a pessoas jurídicas do que físicas. As grandes fusões ou aquisições, os maiores acúmulos de lucros, as mais robustas transferências de capitais e os maiores prejuízos financeiros, para se referir apenas a poucas, mas importantes, situações paradigmáticas, no mais das vezes envolvem juridicamente não pessoas físicas, e sim jurídicas.

Estas, por sua vez, não raro ostentam enorme e altamente complexas divisões de tarefas e grande número de sócios, administradores e trabalhadores e, neste sentido, avultam as dificuldades de atribuição de um fato concreto a alguém a título de autoria, coautoria ou participação.

Assim, muitas vezes sabe-se que a conduta partiu de uma determinada pessoa jurídica, mas não se consegue particularizar a pessoa física autora que a concretizou ${ }^{225}$. E, abstraindo-se da tomada de posição relativamente à capacidade ou incapacidade penal da pessoa jurídica, o fato é que incontestavelmente em nosso sistema jurídico, afora os crimes ambientais, não há imputação a ela para outras formas de delinqüência.

Neste influxo, o Direito Penal Econômico desvela de início já grande incapacidade dogmática estrutural, agravada pela utilização desenfreada das citadas construções porosas de crimes de perigo abstrato, tipos penais abertos, tipos omissivos e

${ }^{224}$ Sobre a tendência para a indeterminação dos agentes da infração econômica, cf. também COSTA, José de Faria. Direito penal..., cit., p. 52 e ss.

${ }^{225}$ SILVEIRA, Renato de Mello Jorge. Direito penal econômico..., cit., p. 74. 
culposos e tipos penais de assessoriedade administrativa, bem como pela incoerência do discurso legitimador dos fins da pena, tudo a consubstanciar um simbolismo penal sem precedentes.

Resta então verificar com pormenor cada uma dessas características para fins de referendar a linha argumentativa até aqui desenvolvida.

\subsubsection{Crimes de perigo abstrato}

Inegável é a utilização desenfreada da categoria de crimes de perigo abstrato, ou presumido, no Direito Penal da sociedade pós-moderna ${ }^{226}$. No ordenamento penal econômico brasileiro, constata-se a ocorrência desse fenômeno com o simples perpassar de olhos em exemplos aleatórios, dentre inúmeros outros, como os dos crimes previstos nos $\operatorname{artigos} 2^{0227}, 3^{\mathrm{o} 228}$ e $4^{\mathrm{o} 229}$ da Lei $\mathrm{n}^{\mathrm{o}} 7.492 / 86$ (crimes contra o sistema financeiro); artigos $63^{230}, 64^{231}, 66^{232}, 69^{233}$ e $70^{234}$ da Lei $n^{\circ} 8.078 / 90$ (crimes contra as relações de consumo)

${ }^{226}$ SGUBBI, Filippo. El delito como riesgo social: investigación sobre las opciones em la asignación de la ilegalidad penal. Trad. Julio E. S. Virgolini. Buenos Aires: Editorial Ábaco de Rodolfo Depalma, 1998, p. 74. 227 "Art. $2^{\circ}$ Imprimir, reproduzir ou, de qualquer modo, fabricar ou pôr em circulação, sem autorização escrita da sociedade emissora, certificado, cautela ou outro documento representativo de título ou valor mobiliário: Pena - Reclusão, de 2 (dois) a 8 (oito) anos, e multa. Parágrafo único. Incorre na mesma pena quem imprime, fabrica, divulga, distribui ou faz distribuir prospecto ou material de propaganda relativo aos papéis referidos neste artigo".

228 "Art. $3^{\circ}$ Divulgar informação falsa ou prejudicialmente incompleta sobre instituição financeira: Pena Reclusão, de 2 (dois) a 6 (seis) anos, e multa".

229 "Art. $4^{\circ}$ Gerir fraudulentamente instituição financeira: Pena - Reclusão, de 3 (três) a 12 (doze) anos, e multa. Parágrafo único. Se a gestão é temerária: Pena - Reclusão, de 2 (dois) a 8 (oito) anos, e multa”.

230 "Art. 63. Omitir dizeres ou sinais ostensivos sobre a nocividade ou periculosidade de produtos, nas embalagens, nos invólucros, recipientes ou publicidade: Pena - Detenção de seis meses a dois anos e multa. § $1^{\circ}$ Incorrerá nas mesmas penas quem deixar de alertar, mediante recomendações escritas ostensivas, sobre a periculosidade do serviço a ser prestado. $\S 2^{\circ}$ Se o crime é culposo: Pena - Detenção de um a seis meses ou multa".

231 "Art. 64. Deixar de comunicar à autoridade competente e aos consumidores a nocividade ou periculosidade de produtos cujo conhecimento seja posterior à sua colocação no mercado: Pena - Detenção de seis meses a dois anos e multa. Parágrafo único. Incorrerá nas mesmas penas quem deixar de retirar do mercado, imediatamente quando determinado pela autoridade competente, os produtos nocivos ou perigosos, na forma deste artigo".

232 "Art. 66. Fazer afirmação falsa ou enganosa, ou omitir informação relevante sobre a natureza, característica, qualidade, quantidade, segurança, desempenho, durabilidade, preço ou garantia de produtos ou serviços: Pena - Detenção de três meses a um ano e multa. $\S 1^{\circ}$ Incorrerá nas mesmas penas quem patrocinar a oferta. $\S 2^{\circ}$ Se o crime é culposo: Pena - Detenção de um a seis meses ou multa".

233 "Art. 69. Deixar de organizar dados fáticos, técnicos e científicos que dão base à publicidade: Pena Detenção de um a seis meses ou multa".

234 "Art. 70. Empregar na reparação de produtos, peça ou componentes de reposição usados, sem autorização do consumidor: Pena - Detenção de três meses a um ano e multa". 
e artigo $27-\mathrm{D}^{235}$ da Lei $\mathrm{n}^{\mathrm{o}} 6.385 / 76$, acrescido pelo artigo $5^{\circ}$ da Lei ${ }^{\circ} 10.303 / 01$ (uso indevido de informação privilegiada).

Atendendo a uma idéia de contenção de riscos ao sistema ${ }^{236}$, as legislações abusam da fórmula, com vistas a que não se afigure sequer uma possibilidade de lesão a determinados interesses sociais. A construção dos crimes de perigo abstrato, opção político-criminal típica da sociedade do risco $^{237}$, representa, dogmaticamente, uma estrutura criminalizadora relativa a um momento prévio a uma lesão ${ }^{238}$.

Em termos especificamente relativos ao Direito Penal Econômico, tal utilização foi tida como válida pela Resolução $\mathrm{n}^{\mathrm{o}} 8$ do Colóquio da Associação Internacional de Direito Penal de $1982^{239}$. Nos dias atuais, referida construção é tamanha que se pode obtemperar a tipificação econômica como uma categoria de direito penal de perigo $^{240}$. Nas palavras de RAFAEL BERRUEZO:

Os tipos dos delitos econômicos requerem cada vez menos a efetiva lesão de um bem jurídico e se estruturam mais sobre a base de um perigo, de modo que os critérios de imputação abandonam o paradigma de delitos de lesão e assumem um contorno comum com os delitos de perigo. Em uma sociedade moderna, com uma grande complexidade de conexões causais, resta ilusório pretender explicar a produção de um dano por apenas um fator, e mais ainda demonstrar sua causalidade em detalhe $\mathrm{e}^{241}$.

Mas, doutrinariamente, há enorme divergência quanto a referida postura, conforme o reconhece o próprio TIEDEMANN, seu mais destacado defensor ${ }^{242}$. Consoante

\footnotetext{
235 “Art. 27-D. Utilizar informação relevante ainda não divulgada ao mercado, de que tenha conhecimento e da qual deva manter sigilo, capaz de propiciar, para si ou para outrem, vantagem indevida, mediante negociação, em nome próprio ou de terceiro, com valores mobiliários: Pena - reclusão, de 1 (um) a 5 (cinco) anos, e multa de até 3 (três) vezes o montante da vantagem ilícita obtida em decorrência do crime".

${ }^{236}$ BOTTINI, Pierpaolo Cruz. Crimes de perigo..., cit., p. 50 e ss.

${ }^{237}$ BOTTINI, Pierpaolo Cruz. Crimes de perigo..., cit., passim.

${ }^{238}$ SILVEIRA, Renato de Mello Jorge. Direito penal econômico..., cit., p. 65.

${ }^{239}$ SILVEIRA, Renato de Mello Jorge. Direito penal econômico..., cit., p. 67.

${ }^{240}$ SILVEIRA, Renato de Mello Jorge. Direito penal econômico..., cit., passim.

241 BERRUEZO, Rafael. Derecho penal económico. In: BERRUEZO, Rafael et all. Derecho penal económico. Montevideo-Buenos Aires: B de F, 2010, p. 75 (tradução livre).

${ }^{242}$ TIEDEMANN, Klaus. Derecho penal..., cit., pp. 84-87. Ao procurar justificar a construção de tipos penais econômicos por meio da técnica de perigo abstrato, o autor alemão chega a afirmar: "Ademais, no caso de bens jurídicos coletivos não é possível, muitas vezes, abarcar os menoscabos dignos de sanção penal em forma racional e constitucional, vale dizer, em forma suficientemente precisa, mas sim devem ser descritas condutas (mais) concretas ou como deveres (...)". TIEDEMANN, Klaus. Derecho penal..., cit., p. 85 (tradução livre).
} 
enumera SILVEIRA ${ }^{243}$, pode-se ainda salientar à frente de um discurso crítico HASSEMER $^{244}$, na Alemanha, SILVA SÁNCHEZ, na Espanha, e REALE JÚNIOR, no Brasil, e, por sua vez, favoravelmente, SCHÜNEMANN, GRACIA MARTIN e MARTINÉZ-BUJÁN PÉREZ, aquele na Alemanha e estes últimos na Espanha.

Uma análise mais detida dos crimes de perigo abstrato será procedida infra, em dois momentos investigativos: quando da análise específica da lesividade penal e, ao depois, em face do estudo da construção teorética de delitos cumulativos. Tal se dará porque, justamente, a maior problematização estrutural verifica-se, no primeiro caso, diante da ausência de constatação de um real vilipêndio a um bem jurídico no momento da conduta, o que fomenta consideráveis críticas à categoria dos delitos de perigo abstrato, assim como, no que diz respeito à construção dos delitos cumulativos, a constatação de uma possível justificação dogmática em razão da afiguração de danos significativos oriundos de um somatório de várias condutas a princípio desvalorativamente inexpressivas em si mesmas. Cuida-se, pois, de aferições curiais pertinentes à discussão dos delitos de perigo em foco, motivo pelo qual seu topos analítico diferenciado revela-se mais adequado.

\subsubsection{Tipos penais abertos}

A construção normativa jurídico-penal por meio de elementos vagos, imprecisos ou ambíguos, cuja significação não pode ser extraída senão utilizando-se de contextualizações externas ao texto legal em análise, é corrente na sociedade do risco ${ }^{245}$. Neste influxo, não poderia ser diferente em matéria de Direito Penal Econômico, mormente quando as complexas relações as quais se buscam tutelar são muitas vezes verdadeiramente incompreendidas por juristas, razão pela qual muitas vezes a redação legislativa é possivelmente, segundo PIMENTEL, delegada a economistas ${ }^{246}$.

\footnotetext{
${ }^{243}$ SILVEIRA, Renato de Mello Jorge. Direito penal econômico..., cit., pp. 68-69.

${ }^{244}$ E demais integrantes da Escola de Frankfurt. Especificamente sobre esta, cf. item "4.1”, abaixo.

245 Muito embora esta construção remonte ao neokantismo (cf., p.ex., BUSTOS RAMÍREZ, Juan. Introducción al..., cit., p. 147 e ss.), seu uso foi verdadeiramente exasperado com a sociedade do risco (Cf., e.g., BOTTINI, Pierpaolo Cruz. Crimes de perigo..., cit., p. 105 e passim; SALVADOR NETTO, Alamiro Velludo. Tipicidade penal..., cit., p.113 e ss.; SILVEIRA, Renato de Mello Jorge. Direito penal supraindividual..., cit., p. 121 e ss.; SOUZA, Luciano Anderson de. Expansão do..., cit., p. 126 e ss.).

${ }^{246}$ Cf. PIMENTEL, Manoel Pedro. Direito penal..., cit., pp. 33-34. Em sentido similar: ROYSEN, Joyce. Histórico da..., cit., p. 194. Neste diapasão, referindo-se à perda de importância do Poder Legislativo no
} 
Nota-se ainda que a superação da dificuldade de entendimento de certos assuntos tutelados, ou mesmo a solução para a dinamicidade da realidade econômica da era da globalização econômica que vivemos - que pode em pouco tempo tornar supérflua ou ultrapassada a proibição legal -, é buscada por meio da utilização de tipos abertos.

Se por um lado, a doutrina majoritária entende pela constitucionalidade dos tipos abertos - uma vez respeitadas balizas mínimas de conteúdo - em face da imprevisibilidade de certas situações para o legislador ${ }^{247}$, o fato é que a realidade pósmoderna vem despontando o exagero da fórmula, por meio da falta de critérios mínimos, gerando insegurança na tipificação, o que, assim, abra caminho ao arbítrio estatal. Segundo GONZÁLEZ:

Outra das características do Direito Penal Econômico está determinada pela existência, em muitos casos, de tipos penais abertos. Isto se dá porque as figuras delitivas que as leis descrevem (Leis de conteúdo econômico) não definem suficientemente a conduta proibida, requerendo uma complementação judicial de seus elementos. É o juiz, no momento de aplicação da lei, quem deve exercer a complementação. Isso pode afetar o princípio da legalidade (...), pois os tipos abertos deixam às vezes uma margem excessiva à apreciação judicial e constituem um convite à aplicação da analogia, que é a negação do princípio "Nullum crimen, nulla poena sine preavia lege", o que é o mesmo que não haver delito sem tipicidade ${ }^{248}$.

Dentre outros, em nossa legislação verificam-se exemplos de tipos penais econômicos abertos - que ademais in casu são também de perigo abstrato - nos artigos $3^{\circ} \mathrm{e}$ $4^{\circ}$, da Lei $n^{\circ} 7.492 / 86$, e 27-D, da Lei $n^{\circ} 6.385 / 76$, acrescido pela Lei ${ }^{\circ} 10.303 / 01$, todos citados acima, e artigo $5^{\circ}$, incisos I, III e IV $^{249}$, da Lei $n^{\circ} 8.137 / 90$ (crimes contra a ordem tributária, econômica e contra as relações de consumo).

processo de tipificação penal econômica italiana, em favor do Executivo, vide: MUSCO, Enzo. El nuevo derecho penal económico entre poder legislativo y poder ejecutivo. In: TERRADILLOS BASOCO, Juan María \& ACALE SÁNCHEZ, María (Coords.). Temas de derecho penal económico: III encuentro hispanoitaliano de derecho penal económico. Madrid: Trota, 2004, pp.169-182.

${ }^{247}$ ZAFFARONI, Eugenio Raúl \& PIERANGELI, José Henrique. Manual de direito..., cit., pp. 386-387.

${ }^{248}$ GONZÁLEZ, Ventura. Nociones generales..., cit., p. 43 (tradução livre).

249 "Art. $5^{\circ}$ Constitui crime da mesma natureza: I - exigir exclusividade de propaganda, transmissão ou difusão de publicidade, em detrimento de concorrência; (...) III - sujeitar a venda de bem ou a utilização de serviço à aquisição de quantidade arbitrariamente determinada; IV - recusar-se, sem justa causa, o diretor, administrador, ou gerente de empresa a prestar à autoridade competente ou prestá-la de modo inexato, 
De fato, tome-se como paradigmática ilustração de tipo penal aberto ilegítimo no ordenamento pátrio o crime de "gestão temerária de instituição financeira" (art. $4^{\circ}$, parágrafo único, da Lei $\left.n^{\mathrm{o}} 7.492 / 86\right)^{250}$. Se não bastasse o fato de que não se vislumbra no tipo qualquer lesividade - o que até poderia, para alguns, ser rebatido por meio da alegação de interesse em se evitar uma conduta potencialmente lesiva ao interesse social - o fato é que ostensivamente fere-se o princípio da taxatividade, e, portanto, da reserva legal ${ }^{251}$, vez que não se sabe o que é gerir temerariamente uma instituição financeira, não havendo quaisquer balizas mínimas a caracterizar o preciso fato ilícito, consideração agravada ainda mais quando se constata que qualquer atividade econômica está naturalmente envolta em riscos. Desta feita, o tipo penal em foco traduz-se num mero subjetivismo do julgador, técnica consagradora de arbítrio estatal.

Dessa forma, constata-se a inconstitucionalidade de tipos que tais, sendo condenável a utilização exacerbada de referida técnica tipificadora, a qual, não obstante, é apenas uma das inseguras fórmulas diuturnamente utilizadas, como já apontado.

\subsubsection{Tipos penais de assessoriedade administrativa}

A complementação dos tipos penais por meio de conceitos, normas ou atos provenientes do Direito Administrativo afigura-se na denominada assessoriedade administrativa do Direito Penal ${ }^{252}$. Relativamente à terminologia correta, nota-se que há divergências na doutrina quanto ao uso de "assessoriedade" ou "acessoriedade"

informando sobre o custo de produção ou preço de venda. Pena - detenção, de 2 (dois) a 5 (cinco) anos, ou multa. Parágrafo único. A falta de atendimento da exigência da autoridade, no prazo de 10 (dez) dias, que poderá ser convertido em horas em razão da maior ou menor complexidade da matéria ou da dificuldade quanto ao atendimento da exigência, caracteriza a infração prevista no inciso IV".

${ }^{250}$ REALE JÚNIOR, Miguel. Instituições de..., cit., p. 277.

${ }^{251}$ Cf., v.g., ARAÚJO JÚNIOR, João Marcello de. Os crimes contra o sistema financeiro no esboço de nova parte especial do Código Penal de 1994. Revista Brasileira de Ciências Criminais, São Paulo, n. 11, 1995, p. 155; PRADO, Luiz Regis. Direito penal..., cit., p. 230.

${ }^{252}$ COSTA, Helena Regina Lobo da. Proteção penal..., cit., p. 65; SILVEIRA, Renato de Mello Jorge. Direito penal econômico..., cit., p. 143 e ss.; CAVERO GARCÍA, Percy. Derecho penal..., cit., p. 137 e ss. e 252 e ss. 
administrativa $^{253}$. Especificando seu entendimento neste exato ponto de sua tese, escreve COSTA:

(...) acredito que a grafia assessoriedade administrativa descreve o fenômeno de modo mais exato, pois remete a idéia de assessorar, ou seja, auxiliar na construção do tipo penal. Assim, abarcam-se não só as situações de efetiva dependência, mas também aquelas de mera complementação conceitual ou normativa $^{254}$.

Tendo em vista que de fato o sentido empregado pela expressão parece atrelar-se mais à idéia de uma formulação jurídica que é auxiliada por normas administrativas, ensejando contínua remissão a estas para fins de complementação, do que propriamente indicativo de algo secundário, preferir-se-á "assessoriedade". Ademais, o dicionário de ANTÔNIO HOUAISS e MAURO DE SALLES VILLAR aponta apenas este último substantivo ${ }^{255}$.

Característico também das normas penais ambientais, de trânsito ou relativas às drogas ilícitas, o fenômeno da assessoriedade administrativa vem consagrando-se no Direito Penal Econômico. Constatam-se emblemáticos exemplos disso, no Direito Penal brasileiro, nos seguintes dispositivos: artigos $7^{\circ}$, incisos, II e $\mathrm{IV}^{256}$, e $22^{257}$, da Lei $\mathrm{n}^{\mathrm{o}}$ $7.492 / 86$ e artigos $6^{\circ}$, incisos I, II e III ${ }^{258}$, e $7^{\circ}$, inciso II $^{259}$, da Lei n ${ }^{\text {o }} 8.137 / 90^{260}$.

${ }^{253}$ E.g., no âmbito da Faculdade de Direito da Universidade de São Paulo, HELENA REGINA LOBO DA COSTA utiliza-se da primeira palavra, enquanto RENATO DE MELLO JORGE SILVEIRA e ANA ELISA LIBERATORE S. BECHARA da última. Cf. COSTA, Helena Regina Lobo da. Proteção penal..., cit., p. 77, passim; SILVEIRA, Renato de Mello Jorge. Direito penal econômico..., cit., p. 144, passim; BECHARA, Ana Elisa Liberatore S. Manipulação genética..., cit., p. 177; BECHARA, Ana Elisa Liberatore S. Direito penal e..., cit., p. 65.

${ }^{254}$ COSTA, Helena Regina Lobo da. Proteção penal..., cit., p. 67.

${ }^{255}$ HOUAISS, Antônio \& VILLAR, Mauro de Salles. Dicionário Houaiss da língua portuguesa. Rio de Janeiro: Objetiva, 2001, p. 52 e p. 321.

256 “Art. $7^{\circ}$ Emitir, oferecer ou negociar, de qualquer modo, títulos ou valores mobiliários: (...) II - sem registro prévio de emissão junto à autoridade competente, em condições divergentes das constantes do registro ou irregularmente registrados; (...) IV - sem autorização prévia da autoridade competente, quando legalmente exigida: Pena - Reclusão, de 2 (dois) a 8 (oito) anos, e multa”.

257 "Art. 22. Efetuar operação de câmbio não autorizada, com o fim de promover evasão de divisas do País: Pena - Reclusão, de 2 (dois) a 6 (seis) anos, e multa. Parágrafo único. Incorre na mesma pena quem, a qualquer título, promove, sem autorização legal, a saída de moeda ou divisa para o exterior, ou nele mantiver depósitos não declarados à repartição federal competente".

258 “Art. $6^{\circ}$ Constitui crime da mesma natureza: I - vender ou oferecer à venda mercadoria, ou contratar ou oferecer serviço, por preço superior ao oficialmente tabelado, ao regime legal de controle; II - aplicar fórmula de reajustamento de preços ou indexação de contrato proibida, ou diversa daquela que for legalmente estabelecida, ou fixada por autoridade competente; III - exigir, cobrar ou receber qualquer vantagem ou importância adicional de preço tabelado, congelado, administrado, fixado ou controlado pelo Poder Público, 
Até pelo fato do Direito Penal Econômico ter como objeto de tutela o sistema econômico e, em última análise, vir-se influenciado em certa medida pela política econômica estatal, o envolvimento com o Direito Administrativo é bastante estreito. As normas oriundas do Banco Central e da Comissão de Valores Mobiliários, as decisões do Conselho Administrativo de Defesa Econômica e as regras de indexação estabelecidas pelo governo em certos casos são exemplos de influências diretas do ramo jurídicoadministrativo na seara penal econômica.

Ocorre que o influxo deste fenômeno é tamanho que se fala em administrativização do Direito Penal:

(...) o termo 'Administrativização' indica que os tipos penais novos tendem a se parecer, na sua forma, cada vez mais, com as normas de intervenção da administração pública, distanciando-se assim dos requisitos 'clássicos' da lei (abstração e generalidade). Dessa forma, as normas penais se transformam em um instrumento de administração de situações particulares, de riscos excepcionais: em outras palavras, um instrumento de resposta contingente a situações de 'emergência' concretas $(. . .)^{261}$.

A assessoriedade administrativa não pode, entretanto, significar a transferência de regramento da conduta à Administração Pública ou ao Direito Administrativo, sob pena de violação do princípio da legalidade penal. Além de caracterizar uma utilização ilegítima do Direito Penal, uma constatação dessa natureza enseja uma importante reflexão acerca de se poder tutelar inteiramente o fato indesejado na seara administrativa (cf. se fará infra, nos Capítulos 4 e 5).

inclusive por meio da adoção ou de aumento de taxa ou outro percentual, incidente sobre qualquer contratação. Pena - detenção, de 1 (um) a 4 (quatro) anos, ou multa".

259 "Art. $7^{\circ}$ Constitui crime contra as relações de consumo: (...) II - vender ou expor à venda mercadoria cuja embalagem, tipo, especificação, peso ou composição esteja em desacordo com as prescrições legais, ou que não corresponda à respectiva classificação oficial; (...) Pena - detenção, de 2 (dois) a 5 (cinco) anos, ou multa. Parágrafo único. Nas hipóteses dos incisos II, III e IX pune-se a modalidade culposa, reduzindo-se a pena e a detenção de $1 / 3$ (um terço) ou a de multa à quinta parte".

${ }^{260}$ Citando parte do rol elencado, cf. SILVEIRA, Renato de Mello Jorge. Direito penal econômico..., cit., p. 144 , nota 144.

261 BARATTA, Alessandro. Funções instrumentais..., cit., p. 12. Sobre o tema, cf. também: REALE JÚNIOR, Miguel. Instituições..., cit., pp. 25-26. 


\subsubsection{Normas penais em branco}

Como referido, dentro do contexto da assessoriedade administrativa, encontram-se as normas penais em branco. Como sabido, as normas penais em branco são aquelas que exigem complementação por outras normas, de nível idêntico (homogêneas) ou diverso (heterogêneas). Quem primeiro estudou o tema - e cunhou a expressão - foi BINDING $^{262}$. Para EDMUND MEZGER, o estudo do tema carecia de significação, pois a complementação necessária sempre faz parte do tipo penal ${ }^{263}$.

De fato, quando se cuida de complementação por meio de norma de mesmo nível, não se vislumbra maior interesse analítico, já que a remissão complementa materialmente o tipo sem se ferir a legalidade penal. Não se revela, dessa maneira, a norma penal em branco homovitelínea abrangida pelo fenômeno da assessoriedade administrativa.

Todavia, é justamente nos casos em que a norma complementadora provém de órgão sem competência jurídico-penal ${ }^{264}$ que surge o questionamento quanto à sua constitucionalidade $^{265}$. E, tendo-se em conta a utilização desenfreada dessa técnica tipificadora nos dias atuais e especialmente no campo da delinquiência econômica, seu acurado estudo faz-se pertinente:

O uso de leis penais em branco encontra-se muito difundido no Direito penal econômico precisamente porque as normas jurídicas neste setor necessitam adaptar-se ao dinamismo da vida econômica. Por esta razão, o tipo penal realiza uma descrição muito genérica da conduta penalmente proibida e se remete a normas extra-penais complementárias para especificar seu conteúdo. Este acoplamento da lei penal com a regulação extra-penal apresenta, todavia, sérios problemas interpretativos, pois como adverte TIEDEMANN, produz-se uma da norma de conduta penal com a norma extra-penal, de tal maneira que o Direito penal econômico assume uma função fundamentalmente assessória no sentido de proteção da regulação extra-penal. Face a esta situação, põe-se o dilema de se

\footnotetext{
262 PIMENTEL, Manoel Pedro. Direito penal..., cit., p. 48; BACIGALUPO, Enrique. La problemática constitucional de las leyes penales em blanco y su repercusión en el derecho penal económico. In: BACIGALUPO, Enrique (Dir.). Derecho penal..., cit., p. 55.

${ }^{263}$ Apud BACIGALUPO, Enrique. La problemática..., cit., p. 54.

${ }^{264}$ Nesse sentido, reitere-se, referidas normas penais em branco encontram-se dentro de um contexto de assessoriedade administrativa, sendo uma espécie desta. Cf., a respeito, CAVERO GARCÍA, Percy. Derecho penal..., cit., p. 254 e ss.

${ }^{265}$ BACIGALUPO, Enrique. La problemática..., cit., p. 55.
} 
as normas complementares devem ser interpretadas a partir de uma perspectiva exclusivamente penal ou manter seu significado penal ${ }^{266}$.

Se por um lado, há os que defendem essa modalidade normativa como única forma de disciplina legal de um campo maleável e ágil como o econômico, mantendo-se a estabilidade do dispositivo fundamental ${ }^{267}$, há o entendimento do extremo oposto no que pertine às normas penais em branco heterogêneas, o qual sustenta sua invalidade por ferirse o princípio da legalidade penal. Uma visão conciliadora pretende analisar cada caso em particular.

Para ENRIQUE BACIGALUPO ${ }^{268}$, dever-se-ia analisar quais são os direitos afetados pelo mandato ou proibição, sendo o limite diferenciador o atingimento de direitos fundamentais. Em caso positivo, haveria de se respeitar a competência legislativa penal.

Ocorre que referido critério do autor espanhol parece pouco claro e de difícil sustentação, já que o Direito Penal necessariamente sempre atinge os direitos humanos fundamentais, uma vez que cerceia a liberdade dos cidadãos, mediante a ameaça ou imposição da resposta jurídico-estatal mais gravosa possível, a sanção penal.

A visão conciliadora revelada pela Suprema Corte espanhola, sem embargo, revela uma interessante construção, que admite ser constitucional:

a utilização e aplicação judicial de leis penais em branco, sempre que houver a satisfatória concreção para a conduta qualificada de delitiva por meio suficientemente preciso no complemento indispensável da norma a que a lei penal se remete, resultando assim salvaguardada a função de garantia do tipo com a possibilidade de conhecimento da atuação penalmente cominada ${ }^{269}$.

Assim, nas hipóteses indispensáveis para a construção de tipos penais, a se evitar o mero casuísmo legislativo, mediante uma concreção clara e precisa da norma

\footnotetext{
${ }^{266}$ CAVERO GARCÍA, Percy. Derecho penal..., cit., pp. 254-255 (tradução livre).

${ }^{267}$ PIMENTEL, Manoel Pedro. Direito penal..., cit., p. 50.

${ }^{268}$ BACIGALUPO, Enrique. La problemática..., cit., pp. 56-57.

${ }^{269}$ Conforme decisão $n^{\circ}$ 127/1990. In: BACIGALUPO, Enrique. La problemática..., cit., p. 53 (tradução livre).
} 
complementadora, estaria justificada a norma penal em branco heterogênea. Seria o caso das substâncias proibidas na lei antidrogas ou do crime de violação de tabela de preços, por exemplo. Nos demais casos, embora o critério da verificação caso a caso possa despontar certa insegurança no intérprete, o fato é que parece o método de compreensão mais adequado para o instituto. De qualquer forma, importante ao exegeta ter em vista que o Direito Penal não é assessório ao Direito Civil, Comercial ou Administrativo, mas que no caso em foco “(...) cumpre sua função mediante o uso de critérios de complementação ou especificação extra-penais" ${ }^{270}$. A assessoriedade administrativa deve ser algo excepcional e, vale dizer, não pode significar transferência de regramento repressivo penal para a alçada administrativa.

\subsubsection{Tipos omissivos e culposos}

Insere-se ainda dentro da ótica de um Direito Penal da sociedade do risco a utilização das formulações tipificadoras omissivas bem como culposas, erigindo um sistema penal de viés preventivo, voltado à conformação de comportamentos e punição à transgressão de deveres impostos pelo Estado.

Dessa maneira, uma vez mais, o Direito Penal Econômico ver-se-á permeado de tipos penais correspondentes, mormente em face do fato de que a intervenção jurídicocriminal com isso contorna uma de suas mais graves problemáticas na hipótese econômica, relativa à identificação da autoria delitiva, em razão da maior facilidade de reconhecimento de destinatários de deveres, prescindindo-se do tradicional caminho da relação causal ${ }^{271}$.

Os crimes omissivos são aqueles em que o agente é punido não porque perpetra uma ação, mas sim porque deixa de realizar o que lhe é juridicamente ordenado ${ }^{272}$, ou seja, não atende àquilo que a lei lhe impõe como necessário. No caso dos omissivos

\footnotetext{
${ }^{270}$ CAVERO GARCÍA, Percy. Derecho penal..., cit., p. 257 (tradução livre). A seguir o autor conclui: “(...) Neste sentido, as normas extra-penais devem ser interpretadas consoante seu âmbito de procedência apenas na medida em que permitam configurar os critérios parciais de decisão estabelecidos pela norma penal ou ajudem a especificá-los nas hipóteses concretas. Os efeitos que tais normas produzem no âmbito extra-penal, pelo contrário, não interessam ao Direito Penal”. CAVERO GARCÍA, Percy. Derecho penal..., cit., p. 257 (tradução livre).

${ }^{271}$ MACHADO, Marta Rodriguez de Assis. Sociedade do..., cit., pp.137-138.

${ }^{272}$ BITENCOURT, Cezar Roberto. Tratado de..., cit. p. 248.
} 
próprios, construção comezinha na sociedade do risco, a lei estabelece um específico dever, o qual, uma vez descumprido, enseja a sanção. Já os impróprios são os crimes de resultado em que quem tem o dever jurídico de evitá-lo, podendo, não o faz. Em qualquer caso, não há uma causalidade fática, circunscrevendo-se a análise a deveres impostos ao agente, alçado à condição de garante no caso dos omissivos impróprios.

Emblemático exemplo dessa tendência hodierna de imposições de deveres pela via de crimes omissivos encontra-se no já citado Sarbanes-Oxley Act, o qual impôs, inclusive extraterritorialmente aos Estados Unidos da América, amplos deveres de informações a serem prestadas a administradores e diretores de empresas, em nome da confiança nas relações negociais. Na específica realidade brasileira, verificam-se casos de penais econômicos de tipos omissivos puros, v.g., nos artigos $10^{273}$ e $12^{274}$ da Lei $n^{\circ}$ $7.492 / 86$ e $63^{275}, 64^{276}$ e $69^{277}$ da Lei $n^{\circ} 8.078 / 90$. Ademais, o emaranhado de normas econômicas, penais e extra-penais ${ }^{278}$, revelam tendência de estabelecimento de garantidores, face as mais diversas obrigações impostas a agentes econômicos, mormente produtores e atuantes no mercado financeiro.

O comportamento culposo, por sua vez, assenta-se na omissão de necessária diligência no atendimento a um dever objetivo de cuidado ${ }^{279}$. Em tempos de incertezas pós-industriais acutiza-se o reclamo social por prevenção de comportamentos

\footnotetext{
273 “Art. 10. Fazer inserir elemento falso ou omitir elemento exigido pela legislação, em demonstrativos contábeis de instituição financeira, seguradora ou instituição integrante do sistema de distribuição de títulos de valores mobiliários: Pena - Reclusão, de 1 (um) a 5 (cinco) anos, e multa".

274 “Art. 12. Deixar, o ex-administrador de instituição financeira, de apresentar, ao interventor, liqüidante, ou síndico, nos prazos e condições estabelecidas em lei as informações, declarações ou documentos de sua responsabilidade: Pena - Reclusão, de 1 (um) a 4 (quatro) anos, e multa”.

275 "Art. 63. Omitir dizeres ou sinais ostensivos sobre a nocividade ou periculosidade de produtos, nas embalagens, nos invólucros, recipientes ou publicidade: Pena - Detenção de seis meses a dois anos e multa. $\S$ $1^{\circ}$ Incorrerá nas mesmas penas quem deixar de alertar, mediante recomendações escritas ostensivas, sobre a periculosidade do serviço a ser prestado. $\S 2^{\circ}$ Se o crime é culposo: Pena Detenção de um a seis meses ou multa".

276 "Art. 64. Deixar de comunicar à autoridade competente e aos consumidores a nocividade ou periculosidade de produtos cujo conhecimento seja posterior à sua colocação no mercado: Pena - Detenção de seis meses a dois anos e multa. Parágrafo único. Incorrerá nas mesmas penas quem deixar de retirar do mercado, imediatamente quando determinado pela autoridade competente, os produtos nocivos ou perigosos, na forma deste artigo".

277 “Art. 69. Deixar de organizar dados fáticos, técnicos e científicos que dão base à publicidade: Pena Detenção de um a seis meses ou multa".

${ }^{278}$ Como, e.g., resoluções do Banco Central do Brasil e da Comissão de Valores Mobiliários.

${ }^{279}$ REALE JÚNIOR, Miguel. Instituições de..., cit., p. 232.
} 
potencialmente lesivos ${ }^{280}$, o que se atende com tipificações culposas sem tais resultados, contornando-se, a um só tempo, as dificuldades probatórias quanto à intencionalidade do agente $^{281}$ e à aferição de um resultado danoso, dando azo a criminalizações de meras condutas, isto é, a simples infrações de deveres.

Exemplos destes tipos culposos no ordenamento penal econômico pátrio encontram-se, dentre outros, nos artigos 63, $\S 2^{\text {a }}$, e 66, $\S 2^{\circ}$, ambos da Lei 8.078/90, correspondente, respectivamente, a omissões culposas quanto à informação de riscos de produtos ou serviços, e a informações falsas culposas ou omissões relevantes culposas quanto a elementos de produtos ou serviços.

Destarte, também o comezinho caminho de construções tipificadoras omissivas e culposas contribui para o erigimento, na sociedade pós-moderna, de um Direito Penal Econômico antecipatório e pouco seguro, voltado à conformação de comportamentos, o que o distancia ainda mais dos contornos liberais do ramo jurídicocriminal.

\subsubsection{A incoerência do discurso legitimador dos fins da pena}

Diante das dificuldades de aplicabilidade anteriormente apontadas - muitas vezes fruto da má técnica legislativa, note-se -, e tendo em vista a identificação do delinqüente econômico como possível agente dotado de maior possibilidade de escape da alçada punitiva, em razão de sua suposta argúcia e poderio econômico, comumente deparase com a defesa de severa punição à delinqüência econômica, a qual somente poderia darse por meio da privação da liberdade ${ }^{282}$. De outra sorte, isto é, qualquer outro tipo de

\footnotetext{
280 "Nessa sociedade em que o risco passa a ser um ingrediente necessário do cotidiano, é evidente que assoma importância o comportamento culposo, que se chega a propor que seja substituído por uma antecipação de tutela penal, dando-se relevância, especialmente na circulação de veículos, à criação de situações perigosas, independentemente de qualquer resultado danoso a alguém, transformando o dano em circunstância qualificadora ou condição objetiva de punibilidade". REALE JÚNIOR, Miguel. Instituições de..., cit., p. 232.

${ }^{281}$ MACHADO, Marta Rodriguez de Assis. Sociedade do..., cit., p. 140.

${ }^{282}$ PIMENTEL, Manoel Pedro. Direito penal..., cit., pp. 92 e ss. Defendendo a máxima punição nos crimes econômicos, cf., e.g., ARAUJO JÚNIOR, João Marcello. Dos crimes..., cit., p. 38. Na doutrina estrangeira, defendendo a resposta prisional, ainda que de curta duração, destacam-se TIEDEMANN, BAJO FERNÁNDEZ, JESCHECK e WEINGEND, e, em sentido contrário, LUZÓN PEÑA e ROXIN. Cf. FEIJOO
} 
resposta, segundo esse pensamento, ingressaria na mera consideração de custo/benefício da atividade econômica ilícita, fazendo-se tábula rasa quaisquer fins preventivos ou retributivos $^{283}$.

A defesa de tratamento sancionatório mais rigoroso do delinqüente econômico relativamente ao infrator comum é assim apontada por JOSÉ DE FARIA COSTA:

(...) $\mathrm{Na}$ verdade, aqui, está-se a lidar com agentes de infracções que não necessitam de qualquer efeito ressocializador, pois, se se quisesse ser desconstritivista, porder-se-ia até dizer que tais agentes "sofrem" é de socialização a mais. Para além disso, nem as mais elevadas sanções pecuniárias têm qualquer efeito dissuasor, não só porque pouco desconforto provocam quando se está perante fortunas astronómicas como, em certas circusntâncias, podem ter só a consequencia de se verem diluídas na opacidade da sua repercussão nos preços dos produtos da empresa ou empresas pertencentes ou dominadas pelo agente da infracção. Daí que a pena curta de prisão, com efeito estigmatizante, seja a que proporciona o efeito dissuasor e complexivo a que toda pena criminal aspira ${ }^{284}$.

Em outras palavras, o estudo da sanção penal em matéria de criminalidade econômica, a despeito da carência de estudos empíricos capazes de apontar o melhor caminho ao legislador ${ }^{285}$, encontra consideráveis defesas político-criminais de

SÁNCHEZ, Bernardo. Sanciones penales y prevención de delitos socioeconómicos. In: BOIX REIG, Javier (Dir.) \& LLORIA GARCIA, Paz (Coord.). Diccionario de derecho penal económico. Madrid: Iustel, 2008, p. 844.

${ }^{283}$ Exemplo significativo da lógica puramente utilitarista, inspirada em POSNER, que simplesmente considera que quanto maior a pena menor é a taxa de criminalidade, ignorando-se outras considerações, é a Sarbanes-Oxley Act, legislação norte-americana de 2002, que fixou elevadas penas de prisão para crimes econômicos. SILVEIRA, Renato de Mello Jorge \& SALVADOR NETTO, Alamiro Velludo. Sarbanes-Oxley Act e..., cit., p. 203. Sobre o tema, estes autores observam: "As normas penais contidas na legislação promulgada, tendo em vista sua própria filosofia inspiradora, demarcam todas as características de um Direito Penal simbólico, voltado às conseqüências e, ademais, com nítido caráter preventivo-pragmático. A premissa adotada é a confiabilidade no mercado, ou seja, a instrumentalização do sistema repressor no sentido de manter, nos agentes econômicos, a expectativa de veracidade acerca das notícias contábeis veiculadas pelas mais diversas empresas". SILVEIRA, Renato de Mello Jorge \& SALVADOR NETTO, Alamiro Velludo. Sarbanes-Oxley-Act e..., cit., p. 201. Posteriormente, os autores voltam a analisar o tema em: SILVEIRA, Renato de Mello Jorge \& SALVADOR NETTO, Alamiro Velludo. A tutela..., cit., p. 384 e ss. Especificamente sobre a análise econômica do Direito Penal, cf. POSNER, Richard A. El análisis económico del derecho. Trad. Eduardo L. Suárez. México, D.F.: FCE, 2007, p. 343 e ss.

${ }^{284}$ COSTA, José de Faria. Direito penal...,cit., pp. 92-93.

${ }^{285}$ Neste sentido, FEIJOO SÁNCHEZ, Bernardo. Sanciones penales..., cit., p. 843. 
recrudescimento repressivo para a hipótese específica, sob a justificativa de evitar-se a impunidade $^{286}$ ou de se alcançar maior efetividade da norma.

Neste contexto, a doutrina penal econômica comumente assinala o caráter preventivo da sanção penal na delinqüência econômica, quer por um discurso em prol do caráter intimidador da pena (prevenção geral negativa), com destaque para a literatura anglo-saxônica, quer por uma defesa preventivo geral positiva, arraigada na doutrina alemã e espanhola, a qual vislumbra na resposta criminal no caso um meio de estabilização das normas essenciais à vida econômica ${ }^{287}$.

Ocorre que a questão é muito mais complexa que o citado discurso preventivo parece revelar, ligando-se à idéia de legitimidade do ramo jurídico-penal como um todo. Como observa SILVA SÁNCHEZ, esta legitimidade não se atrela unicamente tendo como ponto de partida o da teoria das penas, já que a concreta configuração do sistema de Direito Penal mostra-se como produto de uma relação dialética entre o interesse em eliminar a violência social extra-penal e o interesse em diminuir a própria violência do sistema penal $^{288}$.

Neste sentido, o mero utilitarismo preventivo, bastante em voga nos discursos de criminalização difusa, o simples irracionalismo retributivo ou mesmo a combinação de ambos não são capazes de justificar a edição de normas penais de cunho econômico, como, ademais, quaisquer outras.

A ausência de consideração quanto a precisa grave violação ao exato bem jurídico tutelado (lesividade), que não poderia ser defendido de modo menos gravoso (subsidiariedade); a adequação da técnica legislativa para os fins comunicativos pretendidos, com precisão (taxatividade) e proporcionalidade sancionatória ${ }^{289}$, são questões

\footnotetext{
286 TERRADILlOS BASOCO, Juan M. Sistema penal..., cit., p. 53; PIMENTEL, Manoel Pedro. Direito penal..., cit., pp. 27-29.

${ }^{287}$ FEIJOO SÁNCHEZ, Bernardo. Sanciones penales..., cit., p. 844.

288 SILVA SÁNCHEZ, Jesús-María. Aproximación al derecho penal contemporáneo. Barcelona: Bosch Editor, 2002, p. 186.

${ }^{289}$ Especificamente acerca do Direito Penal Econômico, CAVERO GARCÍA nota com propriedade que existem delitos graves e leves, sendo que a sanção prisional somente há de ser reservada aos primeiros. $\mathrm{O}$
} 
essenciais a dotarem de sentido a utilização do drástico ramo jurídico-penal, em qualquer hipótese. Ademais, a ponderação da eficiência do ramo penal para tutela do específico interesse pretendido também há de ser feita.

Assim, a perseguição de fins meramente ordenacionais, de interesses administrativos $^{290}$, por meio do Direito Penal Econômico, sem a existência um bem jurídico penal válido, ostenta-se ilegítima e, visto que consagradora de um mal maior que o que se procura evitar, deve ser combatida.

As categorias penais, portanto, não devem orientar-se unicamente conforme os fins da pena ${ }^{291}$. Há de se atentar se o arcabouço jurídico-criminal possui condições justificadoras e aplicabilidade prática consoante seus objetivos maiores para a tutela penal da ordem econômica. Tal afigura-se uma investigação conjunta de cunho dogmático e político criminal a referendar ou não sua razão de existência, o que se pretende com o presente estudo.

legislador, assim, deve considerar a real lesividade social da delinqüência econômica para a fixação de seu proporcional consectário. Cf. CAVERO GARCÍA, Percy. Derecho penal..., cit. pp. 917-918.

${ }^{290}$ Vide a diferenciação entre bem jurídico e função feita acima.

${ }^{291}$ SILVA SÁNCHEZ, Jesús-María. Aproximación..., cit., passim. 


\title{
2. O CONCEITO DE LESIVIDADE PENAL
}

SUMÁRIO: 2.1. Introdução; 2.2. A lesividade no pensamento penal clássico; 2.2.1. Princípio da lesividade e crimes de perigo abstrato; 2.2.2. Conclusão; 2.3. A lesividade como transgressão ao ordenamento; 2.3.1. Referências críticas e conclusão; 2.4. A busca da demarcação da lesividade nos crimes econômicos.

\subsection{Introdução}

Para perquirição da legitimidade de uma norma penal econômica, deverá o intérprete, preliminarmente, distinguir se o tipo revela-se como protetor de um bem jurídico - no caso, a ordem econômica - ou se simplesmente serve a uma função estatal, a qual, como já afirmado, encerra atividades administrativas do Estado, referentes ao controle sobre determinado setor da vida de relação ou de seu próprio organismo ${ }^{292}$. Nas palavras de TAVARES:

\begin{abstract}
A fonte de confusão entre bem jurídico e função está situada, porém, na indefinição acerca do objeto de referência da norma. O bem jurídico constitui, ao mesmo tempo, objeto de preferência, como valor vinculado à finalidade da ordem jurídica em torno da proteção da pessoa humana, e objeto de referência, como pressuposto de validade da norma, bem como de sua própria eficácia. Neste último caso, ao subordiná-la à demonstração de lesão ou colocação em perigo do bem jurídico ${ }^{293}$.
\end{abstract}

A distinção proposta pelo autor avulta em importância na matéria estudada, eis que a simples adoção de uma política econômica setorial ou momentânea, ou a mera conveniência administrativa em matéria de regulação econômica, sem referência a valores humanos fundamentais ao contrato social carecedores da específica proteção jurídicopenal, não pode representar substrato a uma criminalização válida ${ }^{294}$. Em outras palavras, a

292 TAVARES, Juarez. Teoria do..., cit., p. 204; MANES, Vittorio. Il principio di ofensività..., cit., p. 98.

293 TAVARES, Juarez. Teoria do..., cit., p. 205.

${ }^{294}$ Em sentido oposto, e.g.: "O Direito Penal Econômico traz como uma de suas notas características o aspecto instrumental assumido pela política criminal em face das diversas políticas de Estado desenvolvidas no âmbito da regulação socioeconômica (v.g., política fiscal, política monetária, política cambial). Disso decorre que uma reflexão abalizada sobre o conteúdo material do ilícito nesses territórios pertencentes ao Direito Penal secundário há de ultrapassar os contornos dogmático-penais da figura típica, centrando sua 
utilização do Direito Penal como contundente meio de reforço à política econômica estatal vigente, ignorando-se sua vocação de tutela de bens jurídicos, desvirtua sua característica de ultima ratio na proteção de interesses humanos imprescindíveis para a pacífica convivência social, limitando-se ao mero simbolismo penal ${ }^{295}$ consagrador, desse modo, de um indevido arbítrio do Estado na esfera particular.

Uma vez identificado o bem jurídico tutelado, qual seja, a ordem econômica, no sentido citado das estruturas econômicas de uma sociedade determinada, referenciadas na assecuração da coexistência livre e pacífica de seus indivíduos, o princípio da lesividade é o subseqüente vetor analítico da pertinência do delito econômico:

Em conformidade com o princípio da ofensividade, em um Estado de Direito de cariz social e democrático, o Direito Penal só pode interferir em situações nas quais se verifiquem lesões insuportáveis às condições comunitárias, essenciais ao livre desenvolvimento e realização da personalidade humana, dos quais o trabalho e a ordem econômica estão obrigatoriamente atrelados ${ }^{296}$.

A problematização agrava-se sobremaneira quando se observa que a construção hodiena do Direito Penal Econômico muitas vezes sanciona a inobservância de regras de conveniência da Administração Pública, matérias antes de cunho disciplinar, consagrando o fenômeno da administrativização do Direito Penal ${ }^{297}$, ou ainda, em verdadeira conduta antecipatória da tutela jurídico-criminal, exaspera da formulação de

base referencial nas diretrizes da respectiva ação política, a cuja regular exceção a intervenção jurídico-penal encontra sua justificativa". FELDENS, Luciano \& SCHMIDT, Andrei Zenkner. A associação entre o ilícito administrativo e o ilícito penal no exemplo do crime de evasão de divisas. In: OSÓRIO, Fábio Medina. Direito sancionador: sistema financeiro nacional. Belo Horizonte: Fórum, 2007, pp. 192-193 (itálicos originais).

${ }^{295}$ TERRADILLOS BASOCO, Juan M. Sistema penal..., cit., pp. 58-59.

${ }^{296}$ FERRARI, Eduardo Reale. Legislação penal..., cit. p. 267.

${ }^{297}$ REALE JÚNIOR, Miguel. Instituições de..., cit., p. 21. 
crimes de perigo abstrato, ou presumido, focando-se exclusivamente o desvalor da ação ${ }^{298}$, obliterando-se, então, qualquer aferição concreta de uma lesividade penal ${ }^{299}$.

Neste diapasão, forçoso constatar-se os delineamentos do princípio da lesividade para fins de aferição da adequação estrutural na construção dos tipos penais econômicos. Para tanto, mister se faz analisar o pensamento clássico, ou tradicional, relativo ao temário, assim como o posicionamento que o questiona, atrelado à compreensão da lesividade como lesão de dever - lesividade à instância.

\subsection{A lesividade no pensamento penal clássico}

Consoante o pensamento doutrinário tradicional, o princípio da lesividade, ou ofensividade $^{300}$ (nullum crimen sine iniuria), consiste no vínculo necessário que deve existir entre uma construção penal típica e a lesão ao bem jurídico protegido. Isto não significa, por certo, que há de se exigir sempre um efetivo dano ao bem jurídico tutelado, e sim que se faz necessário ao menos sua relevante afetação ${ }^{301}$. Desse modo, "na verdade, a ofensividade não pode ser interpretada naturalisticamente como o dano provocado em coisas, mas, sim, como potencial de lesão ao interesse sobre a coisa"302.

\section{Segundo JUAREZ CIRINO DOS SANTOS:}

\footnotetext{
${ }^{298}$ SILVEIRA, Renato de Mello Jorge. Direito penal econômico..., cit., p. 91 e ss. e 151. A utilização dos modelos de perigo abstrato é tamanha nos dias atuais que este autor refere-se a um Direito Penal de Perigo, que seria, conforme define com escora em MENDOZA BUERGO, “(...) um Direito Penal adequado às necessidades da atual sociedade pós-industrial, tanto se mostrando como instrumento eficaz de condução de comportamentos, como meio de defesa a novos riscos presentes hodiernamente. Pretende ele, assim, configurar uma idéia de segurança frente às inseguranças sociais”. SILVEIRA, Renato de Mello Jorge. Direito penal econômico..., cit., p. 99.

${ }^{299}$ Para MÉNDEZ RODRÍGUEZ, p. ex., o Direito Penal democrático não se presta a tanto, sendo inválidas tais tipificações. MÉNDEZ RODRÍGUEZ, Cristina. Los delitos de peligro y sus técnicas de tipificación. Madrid: Montano, 1993, p. 162.

300 FERRAJOLI, Luigi. Derecho y razón: teoria del garantismo penal. Madrid: Trotta, 1987, p. 464; SILVEIRA, Renato de Mello Jorge. Direito penal econômico..., cit., pp. 161-162; GOMES, Luiz Flávio. Princípio da ofensividade no direito penal. São Paulo: Revista dos Tribunais, 2002, p. 11. Com base em GARCIA-PABLOS DE MOLINA e MATA Y MARTÍN, dentre nós, MARIÂNGELA GAMA DE MAGALHÃES GOMES entende que é sinônimo da expressão o princípio da exclusiva proteção de bens jurídicos. GOMES, Mariângela Gama de Magalhães. O princípio da proporcionalidade no direito penal. São Paulo: Revista dos Tribunais, 2003, p. 88, nota 17.

${ }^{301}$ SILVEIRA, Renato de Mello Jorge. Direito penal econômico..., cit., p. 163; GOMES, Mariângela Gama de Magalhães. $O$ princípio..., cit., p. 90.

${ }^{302}$ BECHARA, Ana Elisa Liberatore Silva. Da teoria..., cit., p. 236.
} 
o princípio da lesividade proíbe a cominação, a aplicação e a execução de penas e de medidas de segurança em hipóteses de lesões irrelevantes, consumadas ou tentadas, contra bens jurídicos protegidos em tipos legais de crime. Em outras palavras, o princípio da lesividade tem por objeto o bem jurídico determinante da criminalização, em dupla dimensão: do ponto de vista qualitativo, tem por objeto a natureza do bem jurídico lesionado; do ponto de vista quantitativo, tem por objeto a extensão da lesão do bem jurídico ${ }^{303}$.

O tema remonta à distinção entre antijuridicidade formal e material, surgida na Alemanha no início da centúria passada como resposta à crise científica decorrente das insuficiências do positivismo jurídico ${ }^{304}$, uma vez que a mera contrariedade da conduta realizada com o ordenamento jurídico (antijuridicidade formal) mostrara-se insuficiente para justificar uma punição:

\begin{abstract}
se assumimos que o direito penal aspira a um fim de proteção de determinados interesses considerados valorados pela sociedade e, por isso, considerados merecedores e carentes de proteção, as condutas relevantes para ele (aquelas que considerará antijurídicas) serão as que se mostrem lesivas para esses interesses e, por isto, merecedoras e carentes de sanção penal, sendo esta sanção penal o meio com que o direito penal opera no sentido da satisfação desta atribuição de proteção ${ }^{305}$.
\end{abstract}

Dessa maneira, como afirmado supra, para um tipo penal ser válido não apenas se deve identificar em seu bojo um bem jurídico com dignidade penal, como também se constatar a presença de vedação de um comportamento apto a um atingimento significativo do caro valor social tutelado ${ }^{306}$. Esta é a essência do princípio, que se revela assim em mais um filtro da tipificação penal, ou seja, mais um critério limitador do ius puniendi, o que se mostra consentâneo com a regra geral de Direito de que norma restritiva interpreta-se restritivamente $\mathrm{e}^{307}$.

Embora os tratadistas do século XIX não tenham chegado a explicitar o princípio da lesividade, aproximaram-se do tema ao tratar da noção de bem jurídico e dos

\footnotetext{
${ }^{303}$ SANTOS, Juarez Cirino dos. Direito penal: parte geral. Curtiba: ICPC-Lumen Juris, 2008, p. 26. ${ }^{304}$ REALE JÚNIOR, Miguel. Teoria do delito. São Paulo: Revista dos Tribunais, 2000, p. 89.

305 ALCÁCER GUIRAO, Rafael. Sobre el concepto de delito: ¿Lesión del bien jurídico o lesión de deber? Buenos Aires: Ad-Hoc, 2003, p. 13 (tradução livre).

${ }^{306}$ REALE JÚNIOR, Miguel. Instituições de..., cit., pp. 21-22.

${ }^{307}$ MAXIMILIANO, Carlos. Hermenêutica e aplicação do direito. Rio de Janeiro: Forense, 2007, p. 167.
} 
fins do Direito Penal ${ }^{308}$. Fruto da evolução destas reflexões, no início do século XX, com o conceito material de delito de VON LISZT ${ }^{309}$, é que se delineia a noção de modo mais claro. Esta, juntamente com o pensamento de KARL BINDING e ADOLF MERKEL, caracteriza o pensamento clássico, ou tradicional, de lesividade: "Para v. Liszt, Binding e Merkel o direito penal se estrutura sistematicamente através do conceito de bem jurídico, entendido como interesses da vida social juridicamente protegidos, cujas lesões ou exposição a perigo o direito proíbe" ${ }^{\text {"310 }}$.

Embora, segundo o pensamento desde então desenvolvido, esta lesividade não seja fator por si só suficiente a justificar o erigimento de um fato à condição de infração penal $^{311}$, verifica-se a necessidade de sua ocorrência para tal se dar, o que representou um importante salto qualitativo na compreensão da teoria geral do crime, consubstanciando-se em significativo meio de demarcação dos contornos penais.

\subsubsection{Princípio da lesividade e crimes de perigo abstrato}

Após observar que o expansionismo penal da sociedade do risco dá-se, em geral, por meio da utilização da categoria delitiva de perigo abstrato, com vistas ao controle de riscos sociais indesejados ${ }^{312}$, conclui BECHARA:

É justamente em relação aos delitos de perigo que a teoria do bem jurídico e o princípio da ofensividade chegam ao limite de aplicabilidade, pois, embora não se impeça o legislador de proteger bens jurídicos em estágios iniciais de perigo quando for suficientemente identificável a relação entre ambos, deve-se ter cautela na análise crítica de propostas de criminalização de condutas que constituam meros atos preparatórios ou carentes de ofensividade. Nessas hipóteses, estar-se-ia diante de criminalizações fundadas exclusivamente no

\footnotetext{
${ }^{308}$ REALE JÚNIOR, Miguel. Instituições de..., cit., V.I, p. 22.

309 "No seu entender, um fato seria formalmente antijurídico enquanto contrário a uma proibição legal, e materialmente antijurídico por implicar na lesão ou perigo a um bem jurídico, ou seja, formalmente, a antijuridicidade se caracteriza como desrespeito a uma norma, a uma proibição da ordem jurídica; materialmente, como ataque a interesses vitais de particulares e da coletividade protegidos pelas normas estatuídas pelo legislador”. REALE JÚNIOR, Miguel. Teoria do..., cit., p. 89. A respeito do tema, cf. minuciosa explicação deste autor também em: REALE JÚNIOR, Miguel. Antijuridicidade concreta. São Paulo: José Bushatsky, 1973, p. 101 e ss.

${ }^{310}$ REALE JÚNIOR, Miguel. Antijuridicidade..., cit., pp. 101-102.

${ }^{311}$ REALE JÚNIOR, Miguel. Teoria do..., cit., p. 95.

312 BECHARA, Ana Elisa Liberatore Silva. Da teoria..., cit., p. 221.
} 
desvalor da ação, de forma a se marginalizar o desvalor do resultado como elemento secundário e mesmo prescindível na estrutura do delito ${ }^{313}$.

Assim, dentro do contexto do pensamento tradicional do princípio da lesividade, considerando-se, como asseverado, a corrente utilização da categoria de crimes de perigo abstrato, há que se analisar como esta é apreendida em face daquele, uma vez que aparentemente estariam em confronto, já que o princípio da lesividade exige a significativa afetação de um caro valor social pela conduta abstratamente proibida, sendo que não há necessidade de verificação nem de dano efetivo nem de perigo real ao bem jurídico nestes citados crimes ${ }^{314}$.

Com base nesta última constatação, parte da doutrina defende a invalidade dos crimes de perigo abstrato, como o faz, no Brasil, e.g., LUIZ FLÁVIO GOMES e CEZAR ROBERTO BITENCOURT. Consoante este pensamento, faltaria a constatação da antijuridicidade material na hipótese, razão pela qual os tipos seriam de per si ilegítimos ${ }^{315}$. Segundo observa BITENCOURT:

Para que tipifique algum crime, em sentido material, é indispensável que haja, pelo menos, um perigo concreto, real e efetivo de dano a um bem jurídico penalmente protegido. Somente se justifica a intervenção estatal em termos de repressão penal se houver efetivo e concreto ataque a um interesse socialmente relevante, que represente, no mínimo, perigo concreto ao bem jurídico tutelado. Por essa razão, são inconstitucionais todos os chamados crimes de perigo abstrato, pois, no âmbito do Direito Penal de um Estado Democrático de Direito, somente se admite a existência de infração penal quando há efetivo, real e concreto perigo de lesão a um bem jurídico determinado. Em outros termos, o legislador deve abster-se de tipificar como crime ações incapazes de lesar ou, no mínimo, colocar em perigo concreto o bem jurídico protegido pela norma penal. Sem afetar o bem jurídico, no mínimo colocando-o em risco efetivo, não há infração penal ${ }^{316}$.

De acordo com paralelo desenvolvido por SILVEIRA ${ }^{317}$, a tentativa de justificativa para a existência da categoria de crimes de perigo abstrato vincula-se à

\footnotetext{
${ }^{313}$ BECHARA, Ana Elisa Liberatore Silva. Da teoria..., cit., p. 222.

${ }^{314}$ BOTTINI, Pierpaolo Cruz. Crimes de perigo..., cit., p. 203.

${ }^{315}$ GOMES, Luiz Flávio. Princípio da..., cit., pp. 41-42 e passim.

${ }^{316}$ BITENCOURT, Cezar Roberto. Tratado de..., cit., pp. 27-28 (itálicos originais).

${ }^{317}$ Com escora em CUESTA CASTOR e SÁNCHEZ GARCÍA DE PAZ, cf. SILVEIRA, Renato de Mello Jorge. Direito penal econômico..., cit., pp. 85-91. Na doutrina pátria, ainda, e.g., o paralelo é mencionado, mas sem aprofundamento analítico, em SILVA, Ângelo Roberto Ilha da. Dos crimes de perigo abstrato em face da Constituição. São Paulo: Revista dos Tribunais, pp. 139, 141-142 e 150.
} 
operante para os crimes tentados, pois em ambos não há a exigência de configuração de um resultado concreto lesivo. Senão vejamos.

A teoria justificadora para a tentativa inicia-se com FEUERBACH e sua teoria objetiva da perigosidade, segundo a qual é válida a punição pela prática de uma ação que se revista de perigosidade capaz de produzir um resultado danoso ${ }^{318}$. Assim, a idéiaforça preponderante é a de exposição a perigo de um bem jurídico, a ser analisada consoante uma perspectiva ex post ${ }^{319}$.

Os desenvolvimentos seguintes à tese de FEUERBACH ainda seguiram uma tendência de análise objetiva ${ }^{320}$. VON HIPPEL e VON LISZT ${ }^{321}$ apenas acresceram uma valoração ex ante, relativa a uma perigosidade objetiva da ação. Já BINDING, FRANK e DOHNA tomaram apenas o tipo objetivo como objeto de investigação, erigindo a teoria da falta de tipo, que considera o crime tentado uma infração penal de tipo objetivo incompleto. Do mesmo modo, poder-se-ia pensar nesta explanação para o crime de perigo $^{322}$.

É com MEZGER que surge uma primeira contraposição aos ideários até então desenvolvidos, vez que o autor acolhe uma tese subjetivista, focando-se a justificativa punitiva na vontade criminosa (dolo). Referida teoria sofreu principalmente críticas por seu autoritarismo, desvelando um Direito Penal que pune meras intenções ${ }^{323}$.

O pensamento erigido a seguir, finalista, não apresentou quer uma ruptura com as idéias de MEZGER e nem houve por conseguir findar as dúvidas levantadas. Focado na valoração da perigosidade da ação e, desta feita, na capacidade de produção de

\footnotetext{
${ }^{318}$ SILVEIRA, Renato de Mello Jorge. Direito penal econômico..., cit., p. 87.

${ }^{319}$ SILVEIRA, Renato de Mello Jorge. Direito penal econômico..., cit., p. 87.

${ }^{320}$ SILVEIRA, Renato de Mello Jorge. Direito penal econômico..., cit., p. 87.

321 "O que constitui a essência da tentativa no sentido da nossa concepção atual é a direção do ato voluntário a um resultado não produzido, mas representado; a ação parece-nos merecedora de pena, não considerada em si, mas por essa direção. A razão da punibilidade da tentativa está, pois, no caráter perigoso do ato: conquanto não se produzisse o resultado que a lei não quer, o ato suscitou a possibilidade de que ele se produzisse". LISZT, Franz von. Tratado de direito penal alemão. Trad. José Higino Duarte Pereira. Campinas: Russell, 2003, t. I, p. 314.

${ }^{322}$ SILVEIRA, Renato de Mello Jorge. Direito penal econômico..., cit., pp. 87-88.

${ }^{323}$ SILVEIRA, Renato de Mello Jorge. Direito penal econômico..., cit., p. 88.
} 
resultado lesivo, o pensamento finalista pareceu representar uma simbiose de todo o desenvolvimento anterior, sem, contudo, fornecer maiores esclarecimentos ${ }^{324}$.

A doutrina brasileira, consoante se refere SILVEIRA, costuma adotar uma concepção justificadora objetiva, de cunho monista ou dualista, conforme uma consideração desvalorativa exclusiva da ação ou da ação e do resultado:

(...) Pelo primeiro, conforme o princípio da lesividade, vincula-se tanto o legislador, quanto o intérprete da lei. A tentativa há de ser, pois, punida desde que se sobressaia uma conexão real entre conduta e resultado (lesão ou perigo ao bem jurídico), vislumbrando-se, unicamente, um desvalor da ação. $\mathrm{O}$ comportamento dualista, d'outra sorte, é explicado por um desvalor do resultado, evidenciando, pois, que a ação deve provocar uma situação de perigo indicadora de probabilidade de lesão ao bem jurídico. Para a resposta de qual perigo está a se tratar, alguns o entendem concreto, enquanto outros até aceitam o abstrato. Novamente, aqui, as teses ex ante e ex post vão dar o norte de aplicação penal. Qualquer que seja o aceito, entretanto, o real elemento distintivo entre a tentativa e os crimes de perigo é outro. Naquela, dá-se real e fático dolo de lesão, enquanto no segundo, não ${ }^{325}$.

Coaduna desta última posição PIERPAOLO CRUZ BOTTINI, sem, contudo, referir-se à análise atrelada ao crime tentado como ferramenta interpretativa para a consideração relativa à adequação dos crimes de perigo abstrato em face do princípio da lesividade. Analisando a proposta de JOSÉ FRANCISCO DE FARIA COSTA quanto à estruturação de três níveis válidos de lesividade (dano/violação; concreto pôr-em-perigo e cuidado-de-perigo) $)^{326}$, sendo o crime de perigo abstrato aquele que veda uma conduta apta a ofender um bem jurídico (cuidado-de-perigo), o autor brasileiro entende que a análise desta há de se realizar em dois níveis, quais sejam, nos planos legislativo e fático (judicial) $^{327}$.

\footnotetext{
${ }^{324}$ SILVEIRA, Renato de Mello Jorge. Direito penal econômico..., cit., p. 89.

${ }^{325}$ SILVEIRA, Renato de Mello Jorge. Direito penal econômico..., cit., p. 90.

${ }^{326}$ COSTA, José Francisco de Faria. O perigo em direito penal. Coimbra: Coimbra, 2000, pp. 642 e ss.

${ }^{327}$ Cf. BOTTINI: "A construção de FARIA COSTA já oferece elementos para tratar os tipos penais de perigo abstrato como delitos adequados ao princípio da lesividade, no plano legislativo, ainda que não esclareça como o aplicador da norma penal deve atuar para respeitar tal diretriz diante de uma conduta que viole o disposto no texto legal. A lesividade dos crimes de perigo abstrato deve estar presente tanto no plano legal, por meio de dispositivos claros e taxativos que permitam o reconhecimento dos interesses que visa resguardar, quanto no plano fático, ou seja, o juiz, ao aplicar a norma, deverá perquirir pela lesividade da conduta diante das circunstâncias concretas que envolvem sua prática. Esta verificação do potencial lesivo do comportamento se faz por um juízo de periculosidade da ação descrita no tipo como de perigo abstrato. Apenas a conduta que ostente periculosidade tem o condão de movimentar o direito penal de forma legítima.
} 
Neste diapasão, a mera desvaloração da ação, sem consideração prévia e posterior sobre a criação de uma situação apta a potencialmente afetar um interesse humano palpável, afigura-se como de questionável validade ${ }^{328}$. Uma antecipação da tutela penal nestes moldes culmina por perder seu potencial limitador e seus contornos materiais $^{329}$.

\subsubsection{Conclusão}

Ante o exposto, para o pensamento clássico penal, não há como se admitir, num Direito Penal de cunho democrático - que possui a liberdade humana como eixo valorativo -, a simples vedação de condutas indesejadas por uma determinada política estatal, sem que se ostente, claramente, com a mesma, uma grave afetação de um interesse humano fundamental para a coexistência pacífica dos indivíduos.

Entende-se, assim, cabível a vedação de condutas indesejadas por sua danosidade social ${ }^{330}$ ou, ainda, por seu potencial de perigosidade a um interesse humano essencial, não se rechaçando de plano a categoria de perigo abstrato. Mas, ainda que não se exija que a perigosidade seja efetiva, que seja ao menos tangível, provável, capaz em tese de levar à concretização de dano a um caro valor social. Caso em uma análise ex ante ou ex post constate-se que seria impossível a ocorrência de um resultado lesivo na hipótese, inválida será a punição ${ }^{331}$ : no primeiro aspecto, no plano legislativo e, no último, na aplicação da lei no caso concreto.

As ações ou omissões que não impliquem riscos, ao menos potenciais, de afetação do bem jurídico, não podem interessar ao sistema repressor”. BOTTINI, Pierpaolo Cruz. Crimes de perigo..., cit., p. 205.

${ }^{328}$ Em sentido diverso, e.g., entendendo que se deve ter em maior consideração o desvalor da ação em certos casos, ressaltando-se o papel preventivo do Direito Penal com vistas ao futuro: SILVA, Ângelo Roberto Ilha da. Dos crimes de perigo..., p. 138 e ss.

${ }^{329}$ ALCÁCER GUIRAO, Rafael. Sobre el concepto..., cit., p. 86.

${ }^{330}$ REALE JÚNIOR, Miguel. Instituições de..., cit., pp. 21-22.

${ }^{331}$ No sentido do texto, e.g., D'AVILA, Fábio Roberto: “Deve-se inicialmente realizar um juízo ex ante de objetiva e real possibilidade de dano ao bem jurídico protegido e, posteriormente um juízo negativo de significação dessa possibilidade, sob o âmbito normativo do tipo". D’AVILA, Fábio Roberto. Ofensividade e crimes omissivos próprios: contributo à compreensão do crime como ofensa ao bem jurídico. Coimbra: Coimbra, 2005, p. 404. 
Observe-se, todavia, que referido posicionamento não se aproxima da idéia de categoria de crime de perigo abstrato-concreto, lançada por HORST SCHRÖDER e adotada por FRANCESCO ANGIONI ${ }^{332}$, segundo a qual seria possível ao legislador vedar, numa primeira forma, condutas consideradas abstratamente perigosas, mas com previsões para que o aplicador da lei constate, concretamente, elementos deste perigo, além de, numa segunda forma, condutas abstratamente perigosas, mas com relação às quais o legislador não informa qual o bem ou os bens efetivamente protegidos, a ser considerado no caso concreto $^{333}$. Tal ideário, além de se afigurar pouco claro ${ }^{334}$, na primeira espécie pretendida parece se associar à categoria do perigo concreto, enquanto que, no segundo caso, revela-se inseguro.

O que ora se defende, dessa maneira, é ser válido que, numa perspectiva $e x$ ante, o legislador vede uma conduta em tese apta - conforme o conhecimento científico ou a experiência normal ${ }^{335}$ - a ofender um bem jurídico, com presunção relativa ${ }^{336}$ de perigo. Afasta-se, neste contexto, a adoção do princípio da precaução ${ }^{337}$ na construção de tipos penais. A seguir, no entanto, na aplicação da lei ao caso concreto - perspectiva ex post - o juiz deve verificar não se houve um efetivo dano ou concretização de perigo ao bem jurídico, o que caracterizaria um crime de lesão ou de perigo concreto, respectivamente, mas se a presunção relativa de perigo se viu rechaçada por prova em contrário na situação concreta analisada, pois somente dessa forma se amolda a figura do perigo abstrato à exigência da lesividade, dentro de um direito penal garantista ${ }^{338}$.

\footnotetext{
${ }^{332}$ ANGIONI, Francesco. Il pericolo concreto come elemento della fattispecie penale - la struttura oggettiva. Milano: Giuffrè, 1994, p. 87.

${ }^{333}$ SILVA, Ângelo Roberto Ilha da Silva. Dos crimes de perigo..., cit., pp. 79-80; SOUZA, Luciano Anderson de. Expansão do..., cit., p. 124.

${ }_{334}^{334}$ No mesmo sentido: SILVA, Ângelo Roberto Ilha da Silva. Dos crimes de perigo..., cit., p. 80.

${ }^{335}$ REALE JÚNIOR, Miguel. Instituições de..., cit., p. 276.

${ }^{336}$ Esta é a posição de RABL, BAUMANN, U. WEBER, E. GALLO, PATALANO e BERISTAIN, cf. SILVA, Ângelo Roberto Ilha da Silva. Dos crimes..., cit., p. 75. Este autor brasileiro admite a possibilidade de que haja crimes de perigo abstrato com presunção relativa, mas não em todos os casos: SILVA, Ângelo Roberto Ilha da Silva. Dos crimes de perigo..., cit., p. 79.

337 Sobre este, explica BOTTINI: "A aplicação do princípio da precaução decorre da ausência de conhecimentos sobre a periculosidade de determinadas atividades: logo, deriva da inexistência de certezas científicas ou estatísticas sobre quaisquer resultados concretos decorrentes das mesmas, quer de caráter lesivo, quer de caráter perigoso". BOTTINI, Pierpaolo Cruz. Crimes de perigo..., cit., p. 255.

${ }^{338}$ REALE JÚNIOR, Miguel. Instituições de..., cit., p. 277.
} 
Portanto, o princípio da lesividade, nos moldes liberais, mas sem radicalizações no que diz respeito aos crimes de perigo abstrato, afigura-se, juntamente com o princípio da intervenção penal mínima, como critério crítico potencializador da eficácia limitativa da teoria do bem jurídico para a construção de tipos penais ${ }^{339}$. A idéiaforça subjacente a este princípio, deste ponto de vista, reclama a despenalização ${ }^{340}$ de condutas quando não gravemente nocivas para a ordem social ${ }^{341}$.

\subsection{A lesividade como transgressão ao ordenamento}

$\mathrm{Na}$ atualidade, parte da doutrina, com destaque para JAKOBS, vem rechaçando referida concepção tradicional de lesividade, postulando como alternativa uma noção material de crime como violação de vigência da norma ${ }^{342}$, conforme mencionado acima. Neste influxo, o sentido de crime como meio de proteção de bens jurídicos passa a ser substituído por um conceito de delito como lesão de dever, protegendo-se então a vigência do ordenamento, ou seja, o sistema jurídico ${ }^{343}$.

O posicionamento que nega a idéia de lesividade a um bem jurídico como regra justificadora do fenômeno criminalizador, escorando-se na compreensão do delito como lesão de dever, todavia, verdadeiramente, não é novo, apesar de diferentes nuances apresentadas no último século, conforme breve descrição que se faz a seguir, antes de se retornar à teoria do autor de Bonn ${ }^{344}$.

Pode-se apontar HEGEL como o primeiro autor a lastrear o pensamento em foco, a partir de seu entendimento de que o interesse social representa uma essência valorativa superior ao interesse do cidadão, bem como de que a moral coletiva é o

\footnotetext{
${ }^{339}$ No mesmo sentido, cf. BECHARA, Ana Elisa Liberatore Silva. Da teoria ..., cit., p. 243.

${ }^{340}$ MANES, Vittorio. Il principio di ofensività..., cit., p. 242.

341 GARCIA-PABLOS DE MOLINA, Antonio. Introducción al derecho penal. Madrid: Editorial Universitaria Ramon Areces, 2006, p. 542.

${ }^{342}$ ALCÁCER GUIRAO, Rafael. Sobre el concepto..., cit., p. 13; SILVEIRA, Renato de Mello Jorge. Linhas reitoras da..., cit., p. 37; MANES, Vittorio. Il principio di ofensività..., cit., p. 30.

${ }^{343}$ ALCÁCER GUIRAO, Rafael. Sobre el concepto..., cit., p. 14.

${ }^{344}$ Por conta da relevância e atualidade das discussões que esta teoria enseja. Para MANES, a única verdadeira teoria alternativa à da proteção do bem jurídico é a de JAKOBS. Cf. MANES, Vittorio. Il principio di ofensività..., cit., p. 12, nota 2 .
} 
fundamento de identidade do fim estatal de coesão comunitária ${ }^{345}$. Ademais, a idéia de que a sanção penal é a negação da negação do Direito revela a compreensão de que aquela é, de fato, a reafirmação deste ${ }^{346}$.

A seguir, combatendo o ideário liberal-iluminista do bem jurídico, a Escola de Kiel propugnava que o crime representa um ato de infidelidade, de traição à comunidade, ou seja, constituía uma lesão de dever ${ }^{347}$. Conforme AMELUNG:

\begin{abstract}
o valor mais elevado para o pensamento nacional-socialista constitui a comunidade, não o indivíduo. Por isso, a missão mais elevada do direito penal é sua preservação. Porém, este fim não é identificável com a proteção de seus membros. A comunidade é mais que uma soma de indivíduos que convivem juntos. É uma essência viva de uma classe particular, que se assenta muito além do homem individual: é a inseparável comunhão das passadas, presentes e futuras gerações vinculada em torno do sangue e do $\operatorname{solo}^{348}$.
\end{abstract}

Também em WELZEL constata-se a mitigação do sentido liberal da compreensão material do delito, uma vez que a autêntica missão do Direito Penal seria, conforme o autor germânico, a de proteção da vigência dos valores ético-sociais inscritos nas normas ${ }^{349}$. Assim, o desvalor do resultado expressaria a lesão a um bem, enquanto o desvalor da ação, com maior importância, revelaria uma ofensa à vigência do valor ${ }^{350}$.

O neokantismo, por sua vez, apesar de formalmente referir-se à lesão a um bem jurídico, em realidade, esvazia-lhe o conteúdo, pois o entende como um valor ideal comunitário. Dessa maneira, autores críticos desse pensamento, como JESCHECK e SCHMIDHÄUSER, aproximam-se da noção de lesão de dever ao entender o bem jurídico não como uma realidade fática, mas como um valor ideal espiritualizado, similar ao desvalor da ação de WELZEL ${ }^{351}$.

\footnotetext{
345 ALCÁCER GUIRAO, Rafael. Sobre el concepto..., cit., p. 31. Também identificando o pensamento de JAKOBS como próximo ao de HEGEL, na doutrina pátria, cf., e.g., SILVEIRA, Renato de Mello Jorge. Fundamentos da..., cit., p. 42.

${ }^{346}$ ALCÁCER GUIRAO, Rafael. Sobre el concepto..., cit., p. 32.

${ }^{347}$ ALCÁCER GUIRAO, Rafael. Sobre el concepto..., cit., pp. 40-41.

${ }^{348}$ Apud ALCÁCER GUIRAO, Rafael. Sobre el concepto..., cit., p. 39 (tradução livre).

${ }^{349}$ ALCÁCER GUIRAO, Rafael. Sobre el concepto..., cit., pp. 44-51.

${ }^{350}$ ALCÁCER GUIRAO, Rafael. Sobre el concepto..., cit., p. 45.

${ }^{351}$ ALCÁCER GUIRAO, Rafael. Sobre el concepto..., cit., pp. 51-54.
} 
Hodiernamente, o pensamento de JAKOBS, apesar de rechaçar o ideário tradicional da lesividade em prol de uma concepção formal de lesão de dever, baseia-se em diverso corte crítico, partindo sua teoria das concepções sociológicas de LUHMANN ${ }^{352}$. A sociedade é entendida como um sistema social autônomo constituído por um complexo emaranhado de relações comunicativas ${ }^{353}$. Neste sentido, a funcionalidade deste sistema só é possível a partir da existência de uma confiança institucional ou sistêmica, por meio da qual os atores das relações sociais desempenham papéis ${ }^{354}$ - relativamente aos quais os demais atores depositam expectativas comportamentais ${ }^{355}$.

De acordo com a linha argumentativa desenvolvida pelo professor de Bonn, não faz sentido então a compreensão do crime como algo fático relativo a indivíduos e a seus meros interesses particulares e sim como uma lesão ao ordenamento jurídico como um todo ${ }^{356}$. Assim, a lesividade consistiria num ato de violação normativa, isto é, insubordinação sistêmica ou à instância ${ }^{357}$.

\footnotetext{
352 "Com vínculos próximos a Hegel e à própria teoria dos sistemas de Luhmann, Jakobs fundamenta sua construção afirmando que a finalidade da pena é manter a vigência da norma como modelo de contrato social. Aí algumas ponderações de obrigatória menção sobre como se dá o seu relacionamento com o instituto da adequação social. O Direito, desde um prisma luhmaniano, é uma estrutura através da qual se facilita a orientação social, enquanto que a norma se posta como uma geradora de expectativas. A sociedade formar-se-ia e se produziria através do Direito, sendo a missão do Direito Penal garantir tal configuração". SILVEIRA, Renato de Mello Jorge. Fundamentos da..., cit., p. 41.

${ }^{353}$ ALCÁCER GUIRAO, Rafael. Sobre el concepto..., cit., p. 60. Cf. LUHMANN: "No âmbito social, não existe uma multiplicidade de alternativas de modo a escolher, entre elas, a operação que defina o social. A comunicação é o único fenômeno que cumpre com os requisitos: um sistema social surge quando a comunicação desenvolve mais comunicação, a partir da própria comunicação". LUHMANN, Niklas. Introdução à teoria dos sistemas. Trad. Ana Cristina Arantes Nasser. Petrópolis: Vozes, 2009, p. 90.

354 "O conceito de papel, ao mesmo tempo em que está desenhado na medida do ser humano particular, faz alusão a um formato abstrato, no sentido de que o papel pode ser desempenhado por diversos indivíduos de forma similar. O papel se orienta por indicações de destreza do ofício, e exige que se preencha um conjunto de requisitos, sem os quais não seria possível acessá-lo. Portanto, o conceito de papel se propõe a inserir em uma unidade teórica a relação entre indivíduo e sociedade, a partir do momento em que se orienta tanto por expectativas de comportamento segundo o esquema estímulo/resposta, como por expectativas da ação". LUHMANN, Niklas. Introdução à teoria..., cit., p. 254 (itálicos originais).

355 ALCÁCER GUIRAO, Rafael. Sobre el concepto..., cit., pp. 63-64. Segundo JAKOBS: "Da mesma forma que os homens apenas conseguem lidar bem com a natureza na medida em que possam reconhecer regularidades nos contatos sociais - os únicos que interessam aqui -, a orientação também só é possível quando não é preciso contar a cada minuto com um comportamento imprevisível das outras pessoas. Caso contrário, todo contato tornar-se-ia um risco incalculável. O fato de se travar um contato social já é um sinal de que não se espera um desfecho totalmente indeterminado. Se a expectativa é frustrada, surge para o frustrado um conflito ao qual ele deve reagir, pois, com a frustração, constata-se que o balanço entre os eventos com cuja produção ele contou e aqueles que se realizaram não está mais conforme: os modelos de orientação do frustrado devem ser revistos”. JAKOBS, Günther. Tratado de..., cit., pp. 21-22.

${ }^{356}$ ALCÁCER GUIRAO, Rafael. Sobre el concepto..., cit., p. 69.

${ }^{357}$ JAKOBS, Günther. Tratado de..., cit., passim.
} 
Conforme este ponto de vista, o sistema social vê-se abalado pelo comportamento delitivo, razão pela qual somente a sanção penal poderá reconduzi-lo à normalidade, reafirmando ao entorno social que o valor violado permanece vigente. De acordo com JAKOBS: “a função da pena é a preservação da norma enquanto modelo de orientação para contatos sociais. O conteúdo da norma é uma oposição à custa do infrator contra a desautorização da norma" 358 .

Portanto, segundo o autor, como afirmado ${ }^{359}$, os tipos penais, por meio do sistema de penas, protegem expectativas sociais de condutas, referenciadas nos papéis sociais. A sanção penal é, assim, a demonstração da eficácia da norma violada, tendendo à estabilização do ordenamento ${ }^{360}$.

Por fim, merece menção a mais recente obra de BERNARDO FEIJOO SÁNCHEZ acerca do Direito Penal Econômico, relativamente ao presente topos ${ }^{361}$. Indagando-se da hipótese de os delitos econômicos consubstanciarem-se em infrações de dever, e procurando afastar a objeção de falta de referência substancial desta categoria, por conta de uma sinalização positiva, FEIJOO SÁNCHEZ procura harmonizar as idéias atribuindo sentido material a infrações de dever no Direito Penal Econômico mediante a consideração de que existem tipos penais que protegem bens jurídicos mediante a legítima estratégia de garantia do cumprimento de deveres especiais os quais teriam sua origem no desempenho de papéis jurídico-econômicos ${ }^{362}$. Exemplos seriam os do administrador societário, do conselheiro executivo de uma sociedade a qual cotiza em bolsa de valores e do contribuinte tributário, eis que todos não possuiriam somente um dever de não lesionar, aqueles as empresas e este ao fisco ${ }^{363}$, tendo de representar uma função social maior.

Consoante expõe o professor de Madri:

\footnotetext{
358 JAKOBS, Günther. Tratado de..., cit., p. 27.

${ }^{359}$ Item "1.2.1.1".

${ }^{360}$ JAKOBS, Günther. Tratado de..., cit., p. 21, passim.

361 FEIJOO SÁNCHEZ, Bernardo. Cuestiones actuales de derecho penal económico. Montevideo-Buenos Aires: B de F, 2009, p. 228 e ss.

${ }^{362}$ FEIJOO SÁNCHEZ, Bernardo. Cuestiones actuales..., cit., pp. 231-232.

${ }^{363}$ FEIJOO SÁNCHEZ, Bernardo. Cuestiones actuales..., cit., pp. 232 e 245.
} 
a solução que se oferece neste trabalho a muitos dos problemas de imputação que se põem aos delitos econômicos e empresariais passa por uma correta fundamentação material - e não meramente formal - de delitos que têm a ver com especiais deveres de solidariedade e de colaboração, cuja infração equivale normativamente a 'lesionar ou pôr em perigo, ${ }^{364}$.

De acordo com o pensamento desenvolvido, não se trataria de assumir que o Direito protege deveres extra-penais com sanções criminais, mas de constatar que em certas ocasiões as normas penais sancionam fatos socialmente lesivos, fundando-se em critérios que iriam além do mero dever de não causar prejuízos a terceiros ${ }^{365}$.

Em que pese a tentativa de fornecimento de um maior colorido ao ideário de infrações jurídico-penais de cunho econômico como infrações de dever, por conta do sentido de ocupar-se declaradamente este ramo de uma busca pela estabilização de normas de conduta indispensáveis para a manutenção da ordem social, no aspecto econômico vigente $^{366}$, ressaltando-se o caráter da prevenção geral positiva, o pensamento de FEIJOO SÁNCHEZ aproxima-se do de JAKOBS, recebendo assim a mesma sorte de críticas, desenvolvidas a seguir.

\subsubsection{Referências críticas e conclusão}

O Direito Penal representa o mais grave meio de controle social formal ${ }^{367}$ existente, uma vez que cerceia direitos fundamentais dos indivíduos por meio da atuação mais incisiva do Estado. Dessa maneira, este ramo do Direito, desde o período da Ilustração, assumiu simultaneamente os papéis de proteção de interesses sociais imprescindíveis e de garantia do cidadão em face do arbítrio estatal.

\footnotetext{
${ }^{364}$ FEIJOO SÁNCHEZ, Bernardo. Cuestiones actuales..., cit., p. 244 (tradução livre).

365 FEIJOO SÁNCHEZ, Bernardo. Cuestiones actuales..., cit., p. 232. Para o autor: "os tipos penais que configuram o denominado 'moderno Direito Penal', de que resulta um protótipo o Direito Penal econômico, constroem-se em muitas ocasiões a partir da existência de relações ou vínculos jurídicos que excedem os deveres mais básicos ou primários de respeito ou de não lesionar”. FEIJOO SÁNCHEZ, Bernardo. Cuestiones actuales..., cit., p. 245 (tradução livre).

${ }^{366}$ FEIJOO SÁNCHEZ, Bernardo. Cuestiones actuales..., cit., p. 207.

${ }^{367}$ Sobre o tema controle social, vide, e.g., SHECAIRA, Sérgio Salomão. Criminologia..., cit., p. 55 e ss.; REALE JÚNIOR, Miguel. Instituições..., cit., p. 3 e ss.
} 
As duas conseqüências fundamentais deste postulado liberal são: em primeiro lugar, as normas penais devem buscar proteger interesses fundamentais do cidadão relativos às condições essenciais que permitam a ele desenvolver sua liberdade em sociedade ${ }^{368}$; em segundo, a proibição penal de condutas deve estar voltada a ações socialmente danosas para o convívio social, excluindo-se, por exemplo, a proteção de convicções morais ou religiosas ${ }^{369}$.

Para o desempenho deste duplo papel, a teoria do bem jurídico e o princípio da lesividade representam importantes balizas capazes de justificar uma incriminação, assim como, por outro lado, de representar um filtro limitador da atuação do Estado no cerceamento dos direitos essenciais dos cidadãos. A simples punição explicada como resposta a uma violação de dever fixado pelo ordenamento jurídico carece de real conteúdo, remontando ao período doutrinário anterior ao ideário da antijuridicidade material.

Tentando superar as acusações de esvaziamento explicativo por efetiva falta de concretude ofensiva em tipificações comumente erigidas nos dias atuais, parte da doutrina tenta encontrar justificação na construção teórica do bem jurídico espiritualizado. Neste sentido, identifica-se a existência de lesividade na hipótese num plano ideal, atrelado ao desvalor da ação ${ }^{370}$. A lesão a um bem jurídico passa então a ser vista não como uma realidade fática, mas sim como uma valoração ${ }^{371}$, daí falar-se em bem jurídico espiritualizado.

Trilhando-se este ponto de vista, o delito transmutar-se-ia numa lesão ou infração de dever e não mais realmente numa ofensa a um bem jurídico. A valoração na hipótese remonta à idealização hegeliana, não se afigurando como parâmetro seguro para a limitação do poder de punir.

\footnotetext{
${ }^{368}$ ALCÁCER GUIRAO, Rafael. Sobre el concepto..., cit., p. 77.

369 ALCÁCER GUIRAO, Rafael. Sobre el concepto..., cit., p. 78; REALE JÚNIOR, Miguel. Instituições de..., cit., p. 24; FERRAJOLI, Luigi. Derecho y..., passim; ZUGALDÍA ESPINAR, José Miguel. Fundamentos de derecho penal. Valencia: Tirant lo Blanch, 1993, p. 52 e ss.; SANTOS, Juarez Cirino dos. Direito penal..., cit., p.26.

${ }^{370}$ SILVEIRA, Renato de Mello Jorge. Direito penal econômico..., cit., p. 151.

${ }^{371}$ SILVEIRA, Renato de Mello Jorge. Direito penal econômico..., cit., p. 151.
} 


\title{
Conforme afirma REALE JÚNIOR:
}

\begin{abstract}
O valor deve ser apreendido pelo legislador ao produzir a intervenção penal com a edição da norma incriminadora, e este reconhecimento e ponderação do valor como essencial deve ocorrer em face das circunstâncias e da atmosfera espiritual do momento histórico-cultural. Mas a atenção do legislador volta-se à realidade para colher a forma concreta do tipo de conduta que mais gravemente afronta esse valor digno de tutela. (...) Assim tem razão ZIPF ao destacar que esta contrariedade às exigências ético-sociais faz-se em face da 'concreta lesividade social de determinada forma de comportamento', em entendimento secundado por MARIA DA CONCEIÇÃO FERREIRA DA CUNHA, que destaca haver ao lado do grau de importância dos valores a constatação 'dos efeitos de determinados comportamentos no âmbito social a esses mesmos valores ${ }^{372}$.
\end{abstract}

Destarte, a idéia de crime como lesão de dever, asseguramento de aparentes funções do tecido $\operatorname{social}^{373}$, ou transgressão ao ordenamento, por seu formalismo e abstração, não se ostenta adequada a justificar ou a limitar de modo seguro o ius puniendi O pensamento clássico a este respeito mostra-se ainda o mais coerente dogmaticamente e, em face do expansionismo penal das últimas décadas, político criminalmente renovado em sua importância.

\subsection{A busca da demarcação da lesividade nos crimes econômicos}

Diante do desenvolvido até este tópico, insta reiterar algumas específicas conclusões alcançadas, que não apenas servem de balizas para a demarcação da lesividade nos crimes econômicos, como também servirão de importante substrato ao entendimento final pela legitimidade ou não do Direito Penal Econômico.

Inicialmente, reitere-se o fato de que só se admite um tipo penal quando voltado à tutela de um bem jurídico de dignidade penal, qual seja, no caso do Direito Penal Econômico, a ordem econômica. Esta, segundo explicitado, transcendendo à mera política

\footnotetext{
${ }^{372}$ REALE JÚNIOR, Miguel. Instituições de..., cit., p. 23 (itálicos originais).

${ }^{373}$ SILVEIRA, Renato de Mello Jorge. Fundamentos da..., cit., p. 39.
} 
intervencionista do Estado na seara econômica ${ }^{374}$, refere-se às estruturas fundamentais do sistema econômico adotado pelo modelo social.

Todavia, o mero sentido de proteção a um bem jurídico é condição necessária, mas não suficiente, para justificar uma criminalização, sendo forçoso constatar-se, dentre outros $\operatorname{aspectos}^{375}$, o respeito ao princípio da lesividade. Relativamente à delinquiência econômica, isto significa a possibilidade de afetação da estrutura econômica fundamental por meio da conduta proibida. Políticas econômicas transitórias, setoriais ou regionais, quando não atreladas diretamente a graves comportamentos capazes de atingimento da convivência social harmônica, não tutelados de forma mais eficiente por outros meios de controle social que não o jurídico-criminal, não justificam a criminalização econômica.

Desta maneira, o princípio da lesividade obriga, de um lado, o legislador a evitar criminalizações de injustos meramente formais, e, de outro, o intérprete à construção teórica de cada tipo integrado à afetação, atual ou potencial, esta mediante uma perspectiva analítica ex ante e ex post ${ }^{376}$, do bem jurídico em foco ${ }^{377}$. Este o sentido geral metodológico com vistas à demarcação pretendida.

Referida afetação poderá traduzir-se, a partir do pensamento de MIGUEL BAJO FERNÁNDEZ e SILVINA BACIGALUPO SAGGESE, em danos materiais, imateriais e outros efeitos nocivos à livre convivência social ${ }^{378}$.

Em termos materiais, os danos característicos da delinqüência econômica seriam fundamentalmente financeiros, embora os autores espanhóis reconheçam, ainda, a possibilidade de outros danos materiais de maior relevância social, como os contra a vida,

\footnotetext{
${ }^{374} \mathrm{O}$ intervencionismo estatal na economia é característico da alçada administrativa, dando-se por meio direto, como nos casos de serviços de geração e distribuição de energia, saneamento básico e estruturação de rede de transportes, quando o Estado realiza a atividade econômica, ou indireto, este consistente no fomento, regulação, monitoramento, medição, fiscalização, planejamento e ordenação da economia. Cf. MARQUES NETO, Floriano Azevedo. A nova regulação estatal e as agências independentes. In: SUNDFELD, Carlos Ari (Coord.). Direito administrativo econômico. São Paulo: Malheiros, 2006, p. 74.

${ }^{375}$ A serem referidos abaixo.

${ }^{376}$ Conforme referido acima no item "2.2.2".

377 CERVINI, Raúl. Derecho penal económico democrático..., cit.,p. 43.

${ }^{378}$ BAJO FERNÁNDEZ, Miguel \& BACIGALUPO SAGGESE, Silvina. Derecho penal económico. Madrid: Centro de Estudios Ramón Areces, 2001, p. 30.
} 
a integridade física e a saúde, nos exemplos de falsificações de medicamentos e cosméticos, alterações em alimentos, etc. ${ }^{379}$. Embora de fácil assimilação, o corte crítico de referido entendimento é em verdade reduzido, uma vez que não consegue diferenciar em essência um crime econômico do de outra categoria - como dos crimes patrimoniais, no primeiro caso, e dos contra a vida, no último -, bem como privilegia os tipos com resultado concreto, não oferecendo balizas ao intérprete, v.g., para hipóteses de crimes de perigo.

Os danos imateriais, por sua vez, para os autores em foco, atrelam-se à perda de confiança no tráfico mercantil, à deformação do equilíbrio do mercado e à eliminação da concorrência ${ }^{380}$. Tendo em vista que o Direito Penal Econômico tem por escopo resguardar a estrutura econômica da sociedade contra atos gravemente atentatórios, permitindo-se o livre desenvolvimento humano quanto à reprodução e circulação de riquezas, dentro dos parâmetros constitucionais, este último aspecto é importante traço delimitador essencial da lesividade na tipificação econômica.

Assim, mais do que transgressão ao ordenamento, isto é, vilipêndio ao ordenamento jurídico, o que, como visto, carece de conteúdo legitimador, a vulneração da confiança dos agentes econômicos quanto à funcionalidade do mercado - vez que ela compõe seu arcabouço -, ao lado do desvirtuamento estrutural deste, representa um sentido material justificador e diferenciador da incriminação econômica. Exemplo teórico de abalo da confiança econômica capaz de dotar de sentido uma incriminação dá-se com a vedação de divulgação de informação falsa aos consumidores, enquanto que de desvirtuamento estrutural do mercado, com a tutela de livre concorrência, a qual tem o consumidor como beneficiário último de seu correto funcionamento. Já casos concretos de tal abalo deram-se com os escândalos das empresas Enron e WorldCom, vistos acima ${ }^{381}$.

Não obstante, observe-se que grande é a dificuldade que se põe ao legislador e ao intérprete ao procurar, aquele, dimensionar hipoteticamente, e este, mensurar na conduta concretamente analisada, o abalo à ordem econômica. À primeira vista, parece que dificilmente os contornos da técnica penal conseguirão erigir tipos penais precisos capazes

\footnotetext{
${ }^{379}$ BAJO FERNÁNDEZ, Miguel \& BACIGALUPO SAGGESE, Silvina. Derecho penal..., cit., p. 31.

${ }^{380}$ BAJO FERNÁNDEZ, Miguel \& BACIGALUPO SAGGESE, Silvina. Derecho penal..., cit., pp. 31-32.

${ }^{381}$ Item "1.1.4".
} 
de estreita previsão de condutas empresariais - as quais são naturalmente dinâmicas atentatórias ao bem jurídico em foco. Ainda, é pouco crível, num exemplo singelo, que um alimento vencido vendido por um açougue a um único consumidor represente uma sensibilização da confiança social no tráfico mercantil ou o desvirtuamento de suas estruturas básicas $^{382}$.

Sem embargo, a solução legislativa a cláusulas abertas, a serem verificadas pelo aplicador da lei na hipótese fática, como aquela que se dá no citado crime de gestão temerária de instituição financeira (artigo $4^{\circ}$, parágrafo único, da Lei no $7.492 / 86$ ), não é consentânea com o Direito Penal $^{383}$, violando-se o fundamental princípio da taxatividade ${ }^{384}$. Do mesmo modo dá-se com os tipos meramente formais, como os revelados pelos artigos $17^{385}$ e $18^{386}$ da citada $1 \mathrm{ei}^{387}$ dos crimes contra o sistema financeiro, por falta de ofensividade.

\footnotetext{
${ }^{382}$ Neste aspecto, forçoso se faz analisar o tema em foco em face da teoria da cumulatividade delitiva, o que terá campo no capítulo seguinte.

${ }^{383}$ REALE JÚNIOR, Miguel. Instituições de..., cit., p. 277.

${ }^{384}$ PITOMBO, Antônio Sérgio Altieri de Moraes Pitombo. Considerações sobre o crime de gestão temerária de instituição financeira. In: SALOMÃO, Heloisa Estellita (Coord.). Direito penal empresarial. São Paulo: Dialética, 2001, p. 51.

385 "Art. 17. Tomar ou receber, qualquer das pessoas mencionadas no art. 25 desta lei, direta ou indiretamente, empréstimo ou adiantamento, ou deferi-lo a controlador, a administrador, a membro de conselho estatutário, aos respectivos cônjuges, aos ascendentes ou descendentes, a parentes na linha colateral até o $2^{\circ}$ grau, consangǘńneos ou afins, ou a sociedade cujo controle seja por ela exercido, direta ou indiretamente, ou por qualquer dessas pessoas: Pena - Reclusão, de 2 (dois) a 6 (seis) anos, e multa. Parágrafo único. Incorre na mesma pena quem: I - em nome próprio, como controlador ou na condição de administrador da sociedade, conceder ou receber adiantamento de honorários, remuneração, salário ou qualquer outro pagamento, nas condições referidas neste artigo; II - de forma disfarçada, promover a distribuição ou receber lucros de instituição financeira". Sobre este tipo penal, cf., v.g., o posicionamento crítico de MALHEIROS FILHO: "O empréstimo a diretor é em princípio negócio de risco, mas não há sentido em proibir uma instituição de grande porte de oferecer a um diretor empregado um financiamento para aquisição de casa própria ou de automóvel que, além da boa garantia, é de montante insignificante frente à financiadora". MALHEIROS FILHO, Arnaldo. Crimes contra o sistema financeiro na virada do milênio. Boletim IBCCRIM, São Paulo, n. 83, outubro/1999, p. 5.

386 “Art. 18. Violar sigilo de operação ou de serviço prestado por instituição financeira ou integrante do sistema de distribuição de títulos mobiliários de que tenha conhecimento, em razão de ofício: Pena Reclusão, de 1 (um) a 4 (quatro) anos, e multa".

${ }^{387}$ Tamanha a fragilidade técnica da lei em foco - vigente até hoje - que, em mensagem presidencial informando as razões de vetos parciais, o Presidente da República asseverava que em breve enviaria ao Congresso Nacional um novo projeto, aperfeiçoando a matéria. Daí porque ARAÚJO JÚNIOR chamou a Lei n. 7.492/86 de 'lei provisória'. Cf. ARAÚJO JÚNIOR, João Marcello de. Os crimes..., cit., p. 147.
} 
Aliás, sobre esse aspecto, a doutrina econômica defende que não se pode impor rigorismos às tipificações econômicas quanto a verificação de práticas abusivas ${ }^{388}$, o que, conforme se verificará infra ${ }^{389}$, está a despontar melhor adequação de tutela por outro ramo do Direito. Neste sentido, já se manifestou o Conselho Administrativo de Defesa Econômica - CADE, autarquia federal, disciplinada pela Lei $\mathrm{n}^{\circ}$ 8.884/94, que tem a finalidade de orientar, fiscalizar, prevenir e apurar abusos de poder econômico, exercendo papel tutelador da prevenção e da repressão a tais abusos:

(...) é sabido que a lei estabelece no citado art. 21 formas meramente exemplificativas de indícios de práticas anticoncorrenciais, não esgotando nem limitando as práticas passíveis de punição. Todavia, só serão consideradas ilícitas as condutas aptas a produzir ou quando efetivamente produzam os efeitos previstos no art. 20. Assim, a eventual abusividade de tais condutas deverá ser investigada no contexto econômico que se deu, fazendo-se então necessário delimitar corretamente o mercado relevante, verificar o grau de poder dominante do agente e aferir os impactos que a conduta em análise pode eventualmente produzir nesse mercado, ou se já tenha causado algum efeito sobre o ambiente concorrencial ${ }^{390}$.

Neste diapasão, forçoso notar que o papel do CADE na prevenção e repressão de condutas atentatórias à livre concorrência inclui, respectivamente, a determinação de limites prévios à atuação dos agentes econômicos, $e, g$., vedando-se fusões e aquisições ${ }^{391}$, ou a imposição de sanções a empresas por atos anticoncorrenciais ainda que não comprovado qualquer prejuízo efetivo ${ }^{392}$. Há, assim, consoante o regime jurídico fixado a

\footnotetext{
${ }^{388}$ GLÓRIA, Daniel Firmato de Almeida. Direito do consumidor e direito da concorrência. In: OLIVEIRA, Amanda Flávio de. Direito econômico: evolução e institutos. Rio de Janeiro: Forense, p. 182; BRASIL. Conselho Administrativo de Defesa Econômica - CADE. Procedimento Administrativo n. 08000.020787/9662. Voto da Conselheira Lúcia Helena Salgado e Silva.

${ }^{389}$ Capítulo 4.

390 BRASIL. Conselho Administrativo de Defesa Econômica - CADE. Procedimento Administrativo n. 08012.004712/2000-89. Voto do Conselheiro Roberto Augusto Castellanos Pfeiffer.

${ }^{391}$ Sobre isso, cf. o conhecido caso da aquisição da fabricante de chocolates Garoto pela Nestlé, Ato de Concentração n. 08012.001697/2002-89.

${ }^{392}$ Vide teor dos artigos 20 e 21 da Lei n. 8.884/94. Sobre o tema, conforme já se manifestou o CADE: "Na legislação de defesa da concorrência na maioria dos países não é necessário provar os prejuízos de um cartel aos consumidores para condená-lo. Basta se provar a sua existência para presumir-se seus efeitos nocivos. (...) Suponha-se, a título de argumentação, que um cartel clássico não tenha produzido nenhum efeito nocivo para a sociedade. Se tal fato ocorreu, este resultado independeu da vontade das partes, pois elas tinham, pelo simples fato de participar de um Cartel, a intenção de provocar efeitos que prejudicam os consumidores: afinal ninguém corre os riscos e assume os custos de montar um cartel clássico para manter inalterados seus resultados econômicos. Por essa razão, não considerarei para efeitos de prova de ilícito concorrencial os estudos da SDE que tinham por objetivo mostrar os prejuízos para sociedade das práticas das denunciadas". BRASIL. Conselho Administrativo de Defesa Econômica - CADE. Processo Administrativo n. 8012.002127/02-14. Voto do Conselheiro Luiz Carlos Delorme Prado.
} 
partir da Lei n. 8.884/94, a fixação de critérios de lesividade não apenas efetiva, mas potencial $^{393}$.

Tal forma de tutela da ordem econômica, de relevante cunho preventivo e significativa flexibilidade, isto é, menos estrita para mensuração da lesividade a este caro interesse social, bem como com a constante necessidade de análise econômica contextualizada, para aferição, por exemplo, do que significa mercado relevante ${ }^{394}$, posição dominante $^{395}$ e abuso do poder econômico ${ }^{396}$, revela melhor adequação do Direito Administrativo que do Direito Penal para sua proteção ${ }^{397}$.

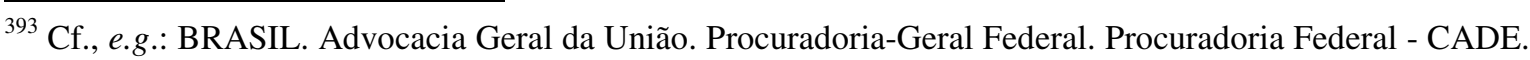
Parecer PROCADE n. 066/2008. Parecer do Procurador Marcos Benacchio; BRASIL. Advocacia Geral da União. Procuradoria-Geral Federal. Procuradoria Federal - CADE. Parecer PROCADE n. 365/2009. Parecer do Procurador Diogo Thomson Andrade; BRASIL. Conselho Administrativo de Defesa Econômica - CADE. Processo Administrativo n. 08012.002299/2000-18. Voto do Conselheiro Afonso Arinos de Mello Franco Neto; BRASIL. Conselho Administrativo de Defesa Econômica - CADE. Ato de Concentração n. 08012.001697/2002-89. Voto do Conselheiro Thompson Andrade. Cf. se verifica paradigmaticamente neste último caso (citado Ato de Concentração envolvendo as empresas Nestlé e Garoto), o CADE utiliza-se inclusive de simulações feitas com base em estimativas econométricas, como a teoria dos jogos de JOHN $\mathrm{NASH}$, para aferição da potencialidade lesiva ao mercado. Admitem-se expressamente presunções nesta demarcação pela lesividade.

394 "O mercado relevante é aquele em que se travam as relações de concorrência ou atua o agente econômico cujo comportamento está sendo analisado. Sem sua delimitação, é impossível determinar a incidência de qualquer das hipóteses contidas nos incisos do art. 20 da Lei 8.884, de 1994". FORGIONI, Paula A. Os fundamentos do..., cit., p. 231. Esta autora observa, a seguir, que a caracterização do ilícito deverá ser aferida no caso concreto, uma vez que o conceito de mercado relevante é elástico, havendo de ser delimitado conforme o critério geográfico e o relativo ao produto. FORGIONI, Paula A. Os fundamentos do..., cit., p. 231 e ss. No mesmo sentido: “(...) o mercado relevante é um conceito construído caso a caso, de modo a permitir a sua adaptação a todos os produtos e serviços. Engessá-lo na lei seria um grande equívoco, pois impossibilitaria sua adaptação a novas circunstâncias". PAGOTTO, Leopoldo U. C. Defesa da concorrência no sistema financeiro. São Paulo: Singular, 2006, p. 157. Assim é que, se dificuldades há já para o Direito Concorrencial no que pertine à segurança jurídica, muito maior o distanciamento desta no tratamento da questão pela via penal, a qual, como afirmado, ostenta menor flexibilidade.

${ }^{395}$ Caracteriza-se, resumidamente, a posição dominante “(...) quando existem condições estruturais que impedem o estabelecimento da concorrência". SALOMÃO FILHO, Calixto. Regulação da atividade econômica: princípios e fundamentos jurídicos. São Paulo: Malheiros, 2008, p. 53. Para FORGIONI, “(...) a posição dominante é decorrência e, ao mesmo tempo, se identifica com o poder detido, pelo agente, no mercado, que lhe assegura a possibilidade de atuar um comportamento independente e indiferente em relação a outros agentes, impermeável às leis do mercado". FORGIONI, Paula A. Os fundamentos do..., cit., p. 318.

396 "Por um lado, o abuso do poder econômico plasma-se sempre que uma empresa se aproveita de sua condição de superioridade econômica para prejudicar a concorrência, inibir o funcionamento do mercado ou ainda, aumentar arbitrariamente seus lucros. Por outro lado, o abuso do poder econômico apresenta-se sob formas variadas. Exemplos disso o truste (pressão de empresas maiores sobre as menores para comandar a política de preços), o cartel (acordo de empresas do mesmo setor, que se organizam entre si para controlar aspectos comuns à sua atividade) e outras práticas consideradas restritivas aos princípios da livre iniciativa e da livre concorrência, como o dumping (discriminação de preços entre mercados nacionais distintos), como os preços predatórios (estratégia de baixar propositadamente os preços de seus produtos a valores inferiores ao seu preço de custo, esperando, com isso, que os concorrentes desistam do mercado daquele setor), como as vendas casadas (prática de subordinar a venda de um bem ou serviço à aquisição de outro) e como os sistemas seletivos de distribuição (restrições impostas, injustificadamente, pelo fabricante ao distribuidor, 
Neste sentido, não se pretende a simplista total negativa da existência do bem jurídico-penal ordem econômica, mas sim considerar ilegítima a utilização deste gravoso ramo de cerceamento da liberdade humana como meio de conformação de condutas, quer para o atendimento de expectativas sociais, quer por conveniências da Administração, ou por meio de critérios inseguros em precisos termos jurídico-penais. Embora sem dúvida a própria dificuldade de identificação do caro valor social envolvido no tipo penal econômico esteja a indicar que o Direito Penal deva ser utilizado apenas em casos extremos, é justamente a tarefa do cientista penal reconhecê-los, para afastar de seu bojo quaisquer outras hipóteses ${ }^{398}$.

E tal reconhecimento dogmático, envolto nas dificuldades gerais de todos os bens jurídicos coletivos, parece se dar por um concurso de critérios. As características de intuito de lucro por parte do agente, de prejuízo efetivo ou potencial de número indeterminado de pessoas e da necessidade de controle social do mercado, com referencial direto ou indireto ao cidadão na condição de ator econômico (principalmente em sua vertente de consumidor, embora também significativa na de empreendedor empresário) consubstanciam-se assim em vetores palpáveis a nortear o legislador e o intérprete. Ao lado disso, a verificação da adequação ou funcionalidade técnica jurídico-penal ${ }^{399}$, tendo-se em vistas critérios como da subsidiariedade, taxatividade, aferição de relação de

utilizadas de forma a discriminar distribuidores, vendedores e consumidores, que acabam por ser prejudiciais à livre concorrência)". MARTINS, Eliezer Pereira. Polícia administrativa econômica. CARDOZO, José Eduardo Martins et all (Orgs.). Curso de direito administrativo econômico. São Paulo: Malheiros, 2006, V. II, p. 355 (itálicos originais). De se notar que não se caracteriza o abuso do poder econômico sem o prejuízo para a concorrência ou o aumento arbitrário de lucros. Neste sentido, cf. FORGIONI, Paula A. Os fundamentos do..., cit., p. 327.

${ }^{397}$ Ademais, nota-se que o CADE possui forte papel regulador da ordem econômica, matéria afeta ao Direito Administrativo. De acordo, e.g., com DI PIETRO: "Para usar uma linguagem própria do direito administrativo brasileiro, pode-se afirmar, sem receio de errar, que dentre as atividades administrativas a cargo do Estado (serviço público, fomento, polícia e intervenção), a atividade regulatória abrange as três últimas, a saber, a polícia, o fomento e a intervenção no domínio econômico". DI PIETRO, Maria Sylvia Zanella. Limites da função reguladora das agências diante do princípio da legalidade. In: DI PIETRO, Maria Sylvia Zanella (Org.). Direito regulatório: temas polêmicos. Belo Horizonte: Forum, 2003, p. 34.

${ }^{398}$ Neste contexto, insta observar uma vez mais que não se partilha da opinião de parte da doutrina de que a Constituição conteria determinações de criminalizações, por tal ser incompatível com os delineamentos de um Direito Penal de ultima ratio. Sobre o tema, e no sentido exposto, cf., por todos, na literatura nacional: PASCHOAL, Janaina Conceição. Constituição, criminalização..., cit., p. 69 e ss.

${ }^{399}$ MANES, Vittorio. Il principio di ofensività..., cit., p. 44. 
causalidade, servirá de diferenciador normativo quanto ao ramo jurídico adequado à tutela desse interesse humano.

A sensibilização de qualquer um desses aspectos, conformando-se um Direito Penal de cunho exclusivamente preventivo, ou seja, antecipatório, com técnicas tipificadoras porosas e flexibilizadas, como meio eficaz de combate a atos contrários à ordem econômica vigente, revela ilegitimidade, denotando insegurança jurídica. Caso se conclua pela escolha da esfera jurídico-administrativa para tutela do caro valor social em foco, não obstante, também há de se verificar seus limites e estruturação. 


\title{
3. A CONSTRUÇÃO DOS DELITOS CUMULATIVOS
}

\begin{abstract}
SUMÁRIO: 3.1. Noção de cumulatividade delitiva; 3.2. O surgimento pragmático do conceito de cumulatividade; 3.3. Perspectiva fundamentadora filosófica: a questão do free-rider; 3.4. Crimes cumulativos como crimes de perigo ou crimes de resultado; 3.5. Cumulatividade e a reconstrução da lesividade penal; 3.6. Delitos cumulativos e sua capacidade justificadora da tutela penal econômica.
\end{abstract}

\subsection{Noção de cumulatividade delitiva}

A cumulatividade delitiva, ou delinqüência por acumulação ${ }^{400}$, liga-se à idéia de punição criminal a condutas que são de per se incapazes de afetação a interesses jurídico-penais, mas que, por critérios político-criminais, são vedadas, uma vez que sua prática disseminada exponencial denotaria abalo (por dano ou por perigo) a um determinado bem jurídico. Trata-se, dessa maneira, de um conceito dogmático atrelado às concepções acerca dos limites da tipicidade e não propriamente de uma técnica legislativa, vez que "revela antes da qualificação de determinados comportamentos como comportamentos típicos ou puníveis" ${ }^{\text {401. }}$.

A noção do instituto foi trazida pelo filósofo do Direito norte-americano JOEL FEINBERG, em 1984, nos estudos denominados The moral limits of the criminal $l a w^{402}$, ao analisar os limites da lei penal diante da pergunta " $E$ se todos fizerem o

\footnotetext{
${ }^{400}$ Expressões provenientes do termo 'crimes cumulativos' em língua alemã: kumulationsdelikt. Na literatura portuguesa, utiliza-se ainda como sinonímia a expressão 'delitos aditivos'. Cf. DIAS, Augusto Silva. "What if everybody did it?": sobre a "(in)capacidade de ressonância" do direito penal à figura da acumulação. Revista Portuguesa de Ciência Criminal, ano 13, $\mathrm{n}^{\circ}$ 3, jul./set. 2003, p. 304, passim; SOUSA, Susana Aires de. Os crimes fiscais: análise dogmática e reflexão sobre a legitimidade do discurso criminalizador. Coimbra: Coimbra, 2006, p. 234, passim.

${ }^{401}$ DIAS, Augusto Silva. "What if..., cit., pp. 305-306. O autor ainda observa: “(...) Pode dizer-se, assim, que a acumulação é um conceito dogmático, que serve para a interpretação de certos tipos e para a imputação de certos comportamentos e que um sector da doutrina pretende fazer entrar na Parte Geral do Direito Penal. Nesse sentido, é um conceito que se aproxima do de adequação social e se afasta do de perigo concreto - que é também sobretudo uma técnica legislativa - ou do de comissão por omissão - que é uma regra de imputação constante da Parte Geral do Código Penal". DIAS, Augusto Silva. "What if..., cit., pp. 305-306.

${ }^{402}$ No primeiro volume de tais estudos (publicados numa coletânea denominada Moral Limits of the Criminal Law Series), cuja temática é a de danos a terceiros, cf. FEINBERG, Joel. The moral limits of the criminal
} 
mesmo?" ${ }^{403}$. Nesse sentido, a função da vedação criminal de condutas na hipótese seria a de se evitar sua repetição em número significativo no seio social, fomentando-se uma situação danosa por conta de sua acumulação, o que FEINBERG denominou de accumulative harms.

O autor norte-americano procura ir além do pensamento de JOHN STUART MILL, segundo o qual o Estado somente pode cercear a liberdade de alguém contra sua vontade quando tiver de proteger a liberdade alheia, a partir do parâmetro do dano a terceiros $^{404}$, entendendo que o princípio do dano (harm principle) não é o único critério legitimador da criminalização de condutas ${ }^{405}$. Nesse sentido:

(...) FEINBERG considera que sob determinadas circunstâncias o risco de conseqüências lesivas pode equiparar-se ao dano efetivo. A partir de tais premissas, admite a criminalização de diversas formas de perigo abstrato. De acordo com a teoria de FEINBERG, as condutas que não causam dano podem ser proibidas sempre que possam dar lugar a consequiências lesivas no futuro, situação em cuja avaliação será determinante a probabilidade e a gravidade de eventual dano a se produzir ${ }^{406}$.

Após referir-se a situações como a de singelos duelos como forma de resolução de conflitos e, ainda, a de sonegação fiscal ${ }^{407}$, no sentido de entender que uma vedação penal não se justificaria quando as pessoas em sua maioria absoluta não agem da forma indesejada, o que, ao revés, a fundamentaria nas hipóteses de baixa motivação éticosocial $^{408}$, FEINBERG analisa a questão da poluição do meio-ambiente. O autor compreende que a poluição atmosférica e da água são casos paradigmáticos de delitos

law: harm to others. Oxford: Oxford University Press, 1987, V. One. Observa-se que a obra aqui referida trata-se de uma reimpressão da originalmente publicada no citado ano de 1984.

${ }^{403}$ Tradução livre do original “What if everybody did it?". FEINBERG, Joel. The moral..., cit., pp. 225-226.

${ }^{404}$ MILL, John Stuart. A liberdade: utilitarismo. Trad. Isaiah Berlin. São Paulo: Martins Fontes, 2000, p. 115 e ss.

${ }^{405}$ HIRSCH, Andrew Von. El concepto de bien jurídico y el "principio del daño". In: HEFENDEHL, Roland (Ed.). La teoría..., cit., p. 39.

${ }^{406}$ HIRSCH, Andrew Von. El concepto..., cit., p. 40 (tradução livre).

${ }^{407}$ FEINBERG, Joel. The moral..., cit., pp. 225-227.

${ }^{408}$ MENDOZA BUERGO, Blanca. El derecho penal en la sociedad del riesgo. Madrid: Civitas, 2001, p. 101; SILVA SÁNCHEZ, Jesús-María. A expansão..., cit., p. 121; BECHARA, Ana Elisa Liberatore S. Delitos de..., cit., p. 3. 
cumulativos $^{409}$, justificando-se a criminalização principalmente em face da importância do valor envolvido $^{410}$.

Cuidando especificamente da seara penal ambiental, isto é, do crime de contaminação de águas ${ }^{411}$, o conceito de delito de acumulação foi dogmaticamente desenvolvido a seguir pelo jurista alemão LOTHAR KUHLEN ${ }^{412}$, professor da Faculdade de Direito e Economia da Universidade de Mannheim, que cunhou a expressão kumulationsdelikt, e, desde então, vem ganhando algumas adesões ${ }^{413} \mathrm{e}$, principalmente, sofrendo grandes questionamentos ${ }^{414}$. Mesmo reconhecendo a existência de aspectos discutíveis de tal antecipação da tutela penal, KUHLEN mostra-se cético em uma solução fora do Direito Penal, diante de um contexto de grandes riscos globais, não vislumbrando, assim, outra maneira de proteção de referido bem de interesse coletivo ${ }^{415}$.

Para o autor germânico, cuida-se de "realizar uma contribuição a solução de grandes problemas mediante a proibição, sob ameaça de sanção, de ações que em suma fornecem pequenas contribuições a constituição destes problemas" ${ }^{\wedge 16}$. Em outras palavras, a conservação, a longo prazo, da natureza, cuja degradação não se dá apenas por um singular e precisamente identificado ato, justifica que este seja punido criminalmente desde já em nome da relevância do interesse protegido. Desta maneira, seu fundamento escora-

\footnotetext{
${ }^{409}$ FEINBERG, Joel. The moral..., cit., p. 228.

${ }^{410}$ FEINBERG, Joel. The moral..., cit., p. 232.

${ }^{411}$ Previsto no $\$ 324$ StGB.

${ }^{412}$ Inicialmente, o autor alemão formulou suas reflexões iniciais sobre o tema em 1986, em artigo intitulado “Der Handlungserfolg der strafbaren Gewässerverunreinigung”, versando sobre a ação de poluição das águas, prevista no Código Penal germânico, pensamento um pouco alterado em 1993 em outro artigo, cujo título é "Umweltstrafrecht - auf der Suche einer neuen Dogmatik", o qual possui como tradução livre "Direito Penal ambiental - em busca de uma nova dogmática". Cf. também do autor, não especificamente acerca do tema, mas a ele relacionado: KUHLEN, Lothar. ¿Es posible limitar el derecho penal por médio de um concepto material de delito? Trad. Pablo Sánchez-Ostiz Gutiérrez. In: El sistema integral del derecho penal: delito, determinación de lapena y proceso penal. Madrid: Marcial Pons Ediciones Jurídicas y Sociales, 2004, p. 129 e ss.; Ainda, citando KUHLEN, v. SILVA SÁNCHEZ, Jesús-María. A expansão..., cit., pp. 121125.

${ }^{413}$ Por distintas perspectivas, o ideário da delinqüência por acumulação culmina por ser admitido, consoante enumeração de BECHARA, na doutrina estrangeira, por ANDREW VON HIRSCH, WOLFGANG WOHLERS, ROLAND HEFENDEHL, GIOVANNI FIANDACA, ENZO MUSCO, JORGE DE FIGUEIREDO DIAS e, em certa medida, JESÚS-MARÍA SILVA SÁNCHEZ. No Brasil, a autora aponta PIERPAOLO C. BOTTINI e FÁBIO R. D’ÁVILA como defensores. Cf. BECHARA, Ana Elisa Liberatore Silva. Da teoria..., cit., p. 258 e ss.

${ }^{414}$ SILVEIRA, Renato de Mello Jorge. Direito penal econômico..., cit., p. 148.

${ }^{415}$ MENDOZA BUERGO, Blanca. El derecho..., cit., p. 144.

${ }^{416}$ Apud SILVA SÁNCHEZ, Jesús-María. A expansão..., cit., p. 123.
} 
se em argumentos utilitaristas de política criminal, sendo significativamente evasivo ${ }^{417}$ quanto às críticas dogmáticas, simplesmente renunciando à teoria liberal do bem jurídico, em nome de uma prognose dita realista ${ }^{418}$. Esta a origem denominada pragmática do conceito de cumulatividade, a qual será melhor analisada abaixo, lastreadora de uma perspectiva de viés sistêmico ${ }^{419}$. No entanto, ainda há uma perspectiva de cunho filosófico moral $^{420}$, como também se deterá infra.

Muito embora todo este ideário relacione-se a bens jurídicos coletivos, particularmente sensível aos temas do meio ambiente e da economia ${ }^{421}$, e, desta feita, encontre-se envolto de interesses de alta carga valorativa no seio social, os principais argumentos contrários a uma dita punição centram-se na idéia de falta de lesividade da conduta punida, por conta da ausência de lesão (ou de perigo) a um bem jurídico protegido, além da violação ao princípio da culpabilidade, uma vez que a punição escora-se ex iniuria tertii, e, por fim, ao princípio da proporcionalidade, dado o descompasso entre a ação vedada e a resposta jurídica cominada (sanção penal) ${ }^{422}$. Não obstante, fato é que referida técnica tipificadora encontrou largo campo expansivo por conta da postura de busca por contenção de riscos da sociedade hodierna, inserindo-se, desta feita, numa lógica preventiva.

\subsection{O surgimento pragmático do conceito de cumulatividade}

Com efeito, a cumulatividade delitiva é construção teórica decorrente do contexto da sociedade do risco ${ }^{423}$. Conforme observa AUGUSTO SILVA DIAS:

\footnotetext{
${ }^{417}$ Neste sentido, SILVA SÁNCHEZ, Jesús-María. A expansão..., cit., p. 123.

${ }^{418}$ Cf. WOHLERS, apud DIAS, Augusto Silva. "What if..., cit., pp. 308-309.

${ }^{419}$ DIAS, Augusto Silva. "What if..., cit., p. 310 e ss.

${ }^{420}$ DIAS, Augusto Silva. "What if..., cit., p. 310 e ss.

${ }^{421}$ Como observa DIAS: “(...) A figura foi introduzida no discurso dogmático por KUHLEN a propósito dos limites da protecção jurídico-penal do ambiente (...), mas alguns adeptos da sua consagração logo a estenderam a domínios como a tutela da administração da justiça, das receitas fiscais do Estado, ou da capacidade funcional de determinados subsistemas do sistema econômico (...)”. DIAS, Augusto Silva. "What if..., cit., pp. 306-307.

${ }^{422}$ Cf., dentre outros, SILVA SÁNCHEZ, Jesús-María. A expansão..., cit., p. 122; DIAS, Augusto Silva. "What if..., cit., passim; BECHARA, Ana Elisa Liberatore S. Delitos de..., cit., pp. 4-5.

${ }^{423}$ No mesmo sentido, entendendo que as profundas alterações econômicas e sociais impuseram uma nova reflexão sobre a função do direito penal, assim como ensejaram uma crise em torno da teoria do bem jurídico, cf. SOUSA, Susana Aires de. Os crimes..., cit., p. 238. V., ainda, DIAS, Augusto Silva. "What if..., cit., p. 310 e ss.; BECHARA, Ana Elisa Liberatore Silva. Da teoria..., cit., p. 257.
} 
A primeira perspectiva de fundamentação, a que chamaremos sistêmica, dá prevalência aos critérios do dano global ou do grande número, isto é, aos prováveis efeitos nocivos para a ordem social que resultarão da acumulação de contributos singulares realizados independentemente uns dos outros ${ }^{424}$.

A sociedade de industrialização tardia, pós-industrial ou do risco, esta última consoante a conhecida expressão alcunhada por BECK, é caracterizada pela radicalização de seus delineamentos, produzindo-se, por conseguinte, consectários contraditórios não desejados pelo modo de produção vigente. Daí falar-se em reflexividade e reflexão ${ }^{425}$, aquela atrelada à idéia da produção de riscos não queridos ${ }^{426}$ e esta na capacidade de reconhecimento destes mesmos riscos, com vistas à sua superação:

Esta reflexão (conhecimento e contato) dos novos riscos, por sua vez, acaba ocasionando fenômenos complexos e de difícil solução na sociedade moderna. A consciência dos novos riscos ao ser largamente difundida, muitas vezes de modo equivocado e midiatizado, salienta uma nova forma de desencantamento. Não mais se desacredita no mundo divino oferecedor de tradições e mitos, mas se impõe a descrença coletiva do homem em lidar de modo confiável com os objetos de sua própria produção. A sociedade, neste instante, caminha da demanda da produção tecnológica para a necessidade de gerenciamento. Passase a buscar sistemas capazes de regular seus próprios contornos, diminuindo a periculosidade da ação do homem em seu universo circundante ${ }^{427}$.

Assim é que a busca por uma produção industrial com maior viabilidade econômica, isto é, com menor custo possível e cada vez maiores lucros, com produtos em constante renovação, em face de um mercado competitivo e ávido por novidades ${ }^{428}$,

\footnotetext{
${ }^{424}$ DIAS, Augusto Silva. "What if..., cit., pp. 310-311.

${ }^{425}$ GIDDENS, Antony; BECK, Ulrich \& LASH, Scott. Modernização reflexiva: política, tradição e estética na ordem social moderna. Trad. Magda Lopes. São Paulo: UNESP, 1997, p. 11 e ss.

426 “(...) o processo de reflexividade descrito pelo autor [BECK] deve ser entendido como confrontação das bases do paradigma da modernidade com as conseqüências da modernização. Esse confronto, entretanto, não nasceu de uma necessidade de se opor ao modelo industrial, nem significou uma opção que se pôde escolher ou rejeitar no decorrer de disputas políticas. Surpreendentemente, derivou do superdesenvolvimento da modernidade industrial, que acabou gerando efeitos e ameaças que não puderam ser assimilados pela racionalidade da época industrial. Ou seja, o confronto, que é a base da reflexividade, significa a incompreensão e a impossibilidade de assimilação da realidade da sociedade do risco pelo sistema da sociedade industrial. De maneira cumulativa e latente, os fenômenos da sociedade do risco produzem ameaças que questionam e, finalmente, destroem as bases da sociedade industrial". MACHADO, Marta Rodriguez de Assis. Sociedade do risco e direito penal: uma avaliação de novas tendências políticocriminais. São Paulo: IBCCRIM, 2005, p. 30.

${ }^{427}$ SALVADOR NETTO, Alamiro Velludo. Tipicidade penal..., cit., pp. 93-94.

${ }^{428}$ Neste sentido, ressaltando a contradição ínsita da sociedade de consumo, consistente na proposta de realizar os desejos materiais humanos ao mesmo tempo em que necessita que estes permaneçam irrealizados,
} 
culmina por dar azo a ampla degradação do meio ambiente e também por se ameaçar as próprias características do sistema econômico, por meio de práticas deletérias à concorrência, aos consumidores e ao Estado. Na seara econômica, pense-se, por exemplo, que a livre iniciativa, a princípio, permite a livre eleição de meios de produção, o que pode na prática redundar em práticas deletérias, prejudiciais a trabalhadores, consumidores e concorrência e, desta feita, à sociedade como um todo.

Uma tal conseqüência contraditória indesejada para um sistema de economia liberal gera como reflexão a busca de sua superação por meio da tentativa de seu afastamento por inúmeros meios regulatórios, como a repressão penal, que se transforma em um elemento a mais do direito de gestão ${ }^{429}$. E, dentro desta transmutada categoria, naturalmente, também se constatam reformulações de entendimentos, com vistas à justificação - ou fundamentação, ou, ainda, validação - deste empreendimento cerceador.

É neste ambiente que exsurge a idealização político-criminal da cumulatividade delitiva, assim como demais discursos defensores do expansionismo penal relativamente aos bens jurídicos supra-individuais, alterando-se o que outrora mostravamse como critérios críticos a afastar a incidência penal em supostos argumentos norteadores de seu alargamento. Trata-se de uma lógica pragmática de gerenciamento de riscos, preventivamente $^{430}$ voltada tanto à proteção da sociedade atual como às futuras gerações $^{431}$. Compreende-se que somente com a ampliação da responsabilidade dos

as palavras de BAUMAN: "A sociedade de consumo tem por premissa satisfazer os desejos humanos de uma forma que nenhuma sociedade do passado pôde realizar ou sonhar. A promessa de satisfação, no entanto, só permanecerá sedutora enquanto o desejo continuar irrealizado; o que é mais importante, enquanto houver uma suspeita de que o desejo não foi plena e totalmente satisfeito. Estabelecer alvos fáceis, garantir a facilidade de acesso a bens adequados aos alvos, assim como a crença na existência de limites objetivos aos desejos 'legítimos' e 'realistas' - isso seria como a morte anunciada da sociedade de consumo. A não satisfação dos desejos e a crença firme e eterna de que cada ato visando satisfazê-los deixa muito a desejar e pode ser aperfeiçoado - são esses os anúncios da economia que têm por alvo o consumidor". BAUMAN, Zygmunt. Vida líquida. Trad. Carlos Alberto Medeiros. Rio de Janeiro: Zahar, 2009, p. 105.

${ }^{429}$ SILVA SÁNCHEZ, Jesús-María. A expansão..., cit., p. 120. Analisando os contornos da sociedade atual, reveladora de indivíduos que tentam incessantemente calcular e minimizar riscos, cf. BAUMAN, Zygmunt. Vida líquida..., cit., p. 90 e ss.

${ }^{430}$ BECHARA, Ana Elisa Liberatore Silva. Da teoria..., cit., p. 256.

431 ALCÁCER GUIRAO, Rafael. La protección del futuro y los daños cumulativos. Revista Electrónica de Ciencia Penal y Criminología, Granada, n. 4, 2002. Disponível em: <http://criminet.ugr.es/recpc >. Acesso em 30/06/2010. 
indivíduos perante o entorno social é que é possível controlar a formação de graves riscos para a existência humana e evitar o perecimento futuro da vida no planeta ${ }^{432}$.

Não obstante, um ideário político-criminal como o descrito encontra dificuldades estruturais no âmbito da construção dogmática penal tradicional de cunho iluminista. Neste sentido, forçoso considerar uma pretendida fundamentação filosófica de cunho moral, assim como o confronto do novel discurso com as categorias de perigo ou de dano, assim como em face da lesividade penal, da proporcionalidade e da culpabilidade, traços dogmáticos de maior vulneração na questão, para fins de se referendar ou não o novo discurso.

\subsection{Perspectiva fundamentadora filosófica: a questão do free-rider}

Além da perspectiva doutrinária fundamentadora sistêmica da construção aditiva, fruto dos contornos da sociedade do risco, ainda há outra, de cariz filosófico moral, baseada nos estudos de FEINBERG e WOHLERS ${ }^{433}$. Trata-se da questão do free-rider, ou

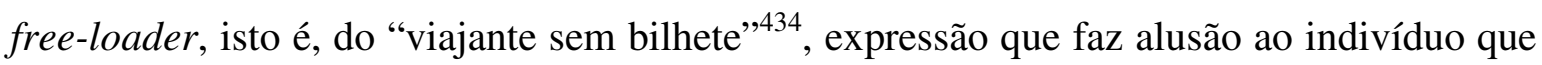
embarca em um trem sem ter pago a correspondente passagem.

Segundo esse pensamento, a vedação penal a comportamentos não em si mesmo lesivos a caros interesses sociais justificar-se-ia diante do caráter reprovável da conduta daquele que se aproveita egoisticamente da honestidade da maioria das pessoas, praticando um ato vantajoso exclusivamente para si em detrimento da coletividade. Assim sendo, seria moralmente condenável o comportamento daquele que lava suas roupas num rio apenas para economizar em sua conta de água.

\footnotetext{
${ }^{432}$ DIAS, Augusto Silva. "What if..., cit., p. 314.

${ }^{433}$ WOHLERS, Wolfgang. Le fattispecie penale come strumento per il mantenimento di orientamenti sociali di carattere assiologico? Problemi di legittimazione da una prospettiva europea continentale e da una angloamericana. In: FIANDACA, Giovanni \& FRANCOLINI, Giovanni (a cura di). Sulla legittimazione del diritto penale: culture europeo-continentale e anglo-americana a confronto. Torino: G. Giappichelli, 2008, pp. 125-152.

${ }^{434}$ DIAS, Augusto Silva. "What if..., cit., p. 316.
} 
Não punir esta última pessoa significaria, ainda de acordo com a linha defendida por estes autores, premiar a desonestidade em detrimento da honradez, razão pela qual o desvalor da conduta do free-rider estaria no aproveitamento egoístico da solidariedade alheia:

(...) Como defende FEINBERG, o que é moralmente condenável no "freeloading" é que o infractor obtém um ganho enquanto os cumpridores, não obstante a sua supremacia moral, sofrem uma perda. Esta situação coloca o universo moral de pernas para o ar: a desonestidade é compensada e a honradez e o civismo são penalizados, ou, pelo menos, não compensados. A impunidade do comportamento do "free-loader" fará vingar socialmente a idéia de que infringir compensa. WOHLERS considera que o desvalor de um tal comportamento assenta na violação do princípio de que todos têm direitos iguais e que a legitimidade da sanção penal respectiva reside precisamente no restabelecimento da igualdade jurídica perturbada $(. . .)^{435}$.

Da mesma forma que numa construção cumulativa, a ação vedada não lesiona diretamente o bem tutelado, mas, dentro da exigência citada de uma prognose realista, sua prática disseminada ensejaria conseqüências sociais danosas ${ }^{436}$. Neste contexto, e por conta da frustração de uma expectativa social de conduta por parte do free-rider, fundamentada estaria uma punição criminal à sua conduta.

Em síntese, este é o esquema teorético que busca uma baliza filosófica moral para a construção penal em análise: a exclusiva desvaloração de um comportamento mesquinho, não cooperante diante do tecido social, mas que se beneficia da cooperação alheia, haveria de ser coibido pelo Direito Penal.

Em razão do seu distanciamento da construção liberal jurídico-criminal, a qual compreende que a imposição de sanções penais apenas se justifica diante de comportamentos que causem lesões ou perigos de lesão a interesses humanos fundamentais à convivência social pacífica, ofertando, ao revés, um ideário legitimador de revalidação de valores vigentes (morais no caso), a análise crítica do pensamento justificador do free-rider

\footnotetext{
${ }^{435}$ DIAS, Augusto Silva. "What if..., cit., pp. 316-317.

${ }^{436}$ DIAS, Augusto Silva. "What if..., cit., p. 319, passim. Cf. SOUSA: “(...) Pressupostos da punibilidade da conduta do free-rider, seriam, em primeiro lugar que todos ou um grande número de pessoas colaborasse na prossecução de um objectivo comum, e, em segundo lugar, que face à impunidade do free-loader, a sua conduta se generalizasse, pondo em causa a prossecução do objectivo coletivo ou a preservação do bem colectivo (...)". SOUSA, Susana Aires de. Os crimes..., cit., pp. 235-236.
} 
dar-se-á conjuntamente com a da perspectiva sistêmica, quando da verificação da "Cumulatividade e a reconstrução da lesividade penal".

\subsection{Crimes cumulativos como crimes de perigo ou crimes de resultado}

O paradigma da construção penal dos delitos cumulativos é o da produção de segurança, fomentando-se a precaução de riscos ${ }^{437}$. Neste sentido, pelo próprio teor do que se entende por delito cumulativo, como constatado, sob um ponto de vista político-criminal de cunho difuso, verifica-se ser indiferente a produção de um resultado lesivo.

Em outras palavras, essencialmente sequer se cogita da produção de um dano ao bem jurídico que se tutela, considerando-se de fato a ação inofensiva. Disso, deflui uma primeira constatação: o delito cumulativo não é um delito de resultado.

De outro lado, tampouco uma citada construção demonstra a exigência de comprovação da produção de um resultado de perigo ao interesse jurídico-penalmente protegido. Isto significa que, dentro de um pensamento doutrinário tradicional, também se afere não se estar diante de uma categoria comumente conhecida como de crime de perigo concreto.

Neste influxo, apesar da doutrina majoritária qualificar a construção cumulativa como sendo de perigo abstrato, entretanto, como nota SUSANA AIRES DE SOUSA $^{438}$, há propostas dissonantes. Não no sentido de atribuir a esta nova categoria o delineamento de delito de resultado, ou de crime de perigo concreto, mas sim identificadora de algum elemento diferenciador na hipótese, dentro da categoria de crimes de perigo, ou ainda, de negativa da exclusiva dualidade "crimes de resultado" versus "crimes de perigo", simplesmente tachando os crimes aditivos como subtipo deste último.

Assim é que a autora portuguesa cita inicialmente SCHÜNEMANN, o qual entende que há três situações de perigo abstrato: a) a de crimes que tutelam bens jurídicos

${ }^{437}$ BECHARA, Ana Elisa Liberatore S. Delitos de..., cit., p. 3; BECHARA, Ana Elisa Liberatore SILVA. Da teoria..., cit., p. 256.

${ }^{438}$ SOUSA, Susana Aires de. Os crimes..., cit., p. 227 e ss. 
intermédios espiritualizados, como a falsificação de documentos, em que haveria um desvalor do resultado mediatizado; b) a de ações massivas, vedadas por razões preventivas, diante dos novos riscos da sociedade atual, e c) a de violações de proibição por conta de um dever subjetivo de cuidado (como no crime de incêndio previsto no $§ 306$ do Código Penal alemão $)^{439}$. Assim sendo, segundo o doutrinador alemão, os delitos cumulativos seriam da segunda espécie descrita, consistindo, portanto, em um preciso sub-tipo de crime de perigo abstrato ${ }^{440}$.

ROLAND HEFENDEHL, por sua vez, demonstra reservas em simplesmente identificar os crimes cumulativos como crimes de perigo abstrato, tendo em vista que “(...) a ideia de acumulação serve de equivalência material à relação que no seio da causalidade lesiva há-de dar-se entre acção e bem jurídico, tornando clara a conexão entre aquelas duas realidades" $" 441$.

Os demais autores citados por SOUSA ${ }^{442}$, os quais sinalizam em certa medida positivamente diante da construção teorética cumulativa, caso dos espanhóis ALCÁCER GUIRAO e de MENDOZA BUERGO, em realidade culminam por abstrair a questão classificatória e minimizar o caráter inofensivo da conduta criminalmente vedada, aproximando-se dos demais argumentos já tratados.

Diante dos posicionamentos referidos, não se vislumbra, dessa maneira, maior justificativa para a negativa de classificação da técnica legislativa em análise como de perigo abstrato. Em realidade, os defensores, em maior ou menor grau, do ideário em questão parecem apenas querer valorizar a construção aditiva, fomentando um pensamento pouco preciso ao ensejo do assunto. Dentro de um contexto de busca por gerenciamento de riscos, e ainda levando-se em consideração o que tradicionalmente se entende como crime de perigo abstrato - aquele em que não se exige a efetivação de perigo para o interesse tutelado -, parece que a categoria dos delitos cumulativos, encontra-se perfeitamente

\footnotetext{
${ }^{439}$ SOUSA, Susana Aires de. Os crimes..., cit., pp. 229-230.

${ }^{440}$ SOUSA, Susana Aires de. Os crimes..., cit., p. 230.

${ }^{441}$ SOUSA, Susana Aires de. Os crimes..., cit., pp. 230-231.

${ }^{442}$ SOUSA, Susana Aires de. Os crimes..., cit., pp. 231-232.
} 
abrigada na caracterização de delitos de perigo abstrato. Isto não significa, contudo, que a construção esteja legitimada.

\title{
3.5. Cumulatividade e a reconstrução da lesividade penal
}

A própria noção de cumulatividade delitiva demonstra que na hipótese a “(...) punição não atinge comportamentos concretamente ofensivos, buscando-se, ao invés, proteger a eficiência social de determinadas funções por meio do Direito Penal (...)"443. Neste sentido, nas palavras de JESUS-MARÍA SILVA SÁNCHEZ:

\begin{abstract}
Pois bem, é possível afirmar que é uma característica do Direito Penal das sociedades pós-industriais a assunção, em ampla medida, de tal forma de racionalizar, a da lesividade global derivada de acumulações ou repetições, tradicionalmente própria do administrativo. É isso que se quer indicar quando se alude ao processo de 'administrativização', em que, a nosso juízo, se acha imerso o Direito Penal. E tal poderia nos levar ainda mais longe: assim, não somente afirmar que o Direito penal assume o modo de racionalizar próprio do Direito Administrativo sancionador, senão que inclusive, a partir daí, se converte em um Direito de gestão ordinária de grandes problemas sociais ${ }^{444}$.
\end{abstract}

Assim, não há que se cogitar de lesividade in casu, face à impossibilidade de se estabelecer um nexo de ofensa relevante entre as mínimas contribuições individuais ${ }^{445}$ e a vulneração real ou potencial do interesse tutelado.

Neste diapasão, os defensores da construção em foco apresentam justificativas de cunho político criminal que procuram contornar essa inquestionável constatação dogmática, conforme se nota em autores oriundos da Espanha, Portugal, Alemanha e Brasil, exemplificativamente elencados a seguir ${ }^{446}$.

SILVA SÁNCHEZ, por razões comunicativas atreladas à capacidade motivadora dos cidadãos, ou seja, privilegiando a prevenção geral positiva, admite excepcionalmente os delitos cumulativos, desde que não se comine a tais vedações a pena

\footnotetext{
${ }^{443}$ BECHARA, Ana Elisa Liberatore S. Delitos de..., cit., p. 4.

${ }^{444}$ SILVA SÁNCHEZ, Jesús-María. A expansão..., cit., p. 120.

${ }^{445}$ ALCÁCER GUIRAO, Rafael. La protección..., cit., p. 15.

${ }^{446}$ Conforme os pertinentes exemplos de BECHARA, Ana Elisa Liberatore S. Delitos de..., cit., p. 4.
} 
privativa de liberdade ${ }^{447}$. Assim, admite-os num contexto que chama de "segunda velocidade" do Direito Penal.

JORGE DE FIGUEIREDO DIAS, a seu turno, no bojo da proteção penal ambiental $^{448}$, apresenta um discurso voltado à necessidade de contenção de riscos globais e preservação das futuras gerações ${ }^{449}$. A proteção ao bem jurídico seria desse modo mediata, ante a constatação empírica de uma provável acumulação, de maneira a gerar um perigo de dano $^{450}$.

No mesmo sentido é o entendimento de KLAUS TIEDMANN, o qual, também se detendo na matéria ambiental, assevera que os perigos a este interesse humano essencial não podem ser compreendidos nem de forma aproximada $^{451}$. Os riscos envolvidos, então, justificariam a intervenção do Direito Penal.

ANDREW VON HIRSCH e WOLFGANG WOHLERS, de modo similar, procuram legitimar a construção cumulativa a partir da compreensão de que existe um dever geral de cooperação no entorno social, baseada nos papéis desempenhados por cada indivíduo no contexto da sociedade, devendo apenas isso estar condicionado a uma prognose realista e à consideração das particularidades de cada pessoa ${ }^{452}$.

$\mathrm{Na}$ doutrina brasileira, destacam-se os posicionamentos de FÁBIO ROBERTO D'ÁVILA e de PIERPAOLO CRUZ BOTTINI ${ }^{453}$. O primeiro autor procura escorar a admissão da categoria conforme o contexto social (ou real), de acordo com o interesse de preservação do meio ambiente. Já BOTTINI, por sua vez, coaduna com a

\footnotetext{
447 BECHARA, Ana Elisa Liberatore S. Delitos de..., cit., p. 4; BECHARA, Ana Elisa Liberatore SILVA. Da teoria..., cit., p. 261.

${ }^{448}$ DIAS, Jorge de Figueiredo. Sobre a tutela jurídico-penal do ambiente - um quarto de século depois. In: DIAS, Jorge de Figueiredo et all (Orgs.). Estudos em homenagem a Cunha Rodrigues, v. I. Coimbra: Coimbra, 2001, p. 390 e ss. Também se refere a este texto: DIAS, Augusto Silva. "What if..., cit., p. 304.

${ }_{449}^{4}$ DIAS, Jorge de Figueiredo. O papel..., cit., pp. 603-614.

${ }^{450}$ BECHARA, Ana Elisa Liberatore S. Delitos de..., cit., p. 4; BECHARA, Ana Elisa Liberatore SILVA. Da teoria..., cit., p. 260.

${ }^{451}$ BECHARA, Ana Elisa Liberatore S. Delitos de..., cit., p. 4; BECHARA, Ana Elisa Liberatore SILVA. Da teoria..., cit., pp. 260-261.

${ }^{452}$ BECHARA, Ana Elisa Liberatore SILVA. Da teoria ..., cit., pp. 258-259.

${ }^{453}$ BECHARA, Ana Elisa Liberatore S. Delitos de..., cit., p. 4; BECHARA, Ana Elisa Liberatore SILVA. Da teoria..., cit., pp. 261-262.
} 
construção, desde que haja repetição de condutas por uma mesmo agente ou ainda se houver prévia combinação entre diversos.

Diante dos pensamentos esposados por tais autores, com escólio em BECHARA, formula-se uma reflexão crítica que chama a atenção para a premência de consagração de um Direito penal de cunho racionalista ${ }^{454}$. Inicialmente, no que tange à teoria de SILVA SÁNCHEZ, nota-se que a consagração de dois subsistemas não comunicáveis implicaria em verdade uma quebra do sistema jurídico-penal ${ }^{455}$, que ficaria carente de sentido na chamada "segunda velocidade", vez que novos conceitos e institutos deveriam ser erigidos, distanciando-se da racionalidade penal clássica ${ }^{456}$. Ademais, como adverte ALBERTO SILVA FRANCO, face a seletividade penal, possivelmente esta insólita dualidade refletir-se-ia de forma injusta nos imputados, levando-se o poderoso a responder na esfera menos gravosa, isto é, sem o consectário da pena privativa de liberdade, enquanto o desvalido permaneceria na alçada tradicional, de caráter prisional ${ }^{457}$.

A opção político criminal de JORGE DE FIGUEIREDO DIAS, a seu turno, em face da ausência de certeza científica ou estatística acerca de resultados efetivos danosos ou perigosos a um bem jurídico palpável atrelado a indivíduos, afigura-se como vinculada ao princípio da precaução ${ }^{458}$. Desse modo, referida visão ofertada pelo catedrático de Coimbra, não se coaduna com as exigências de um Direito Penal garantista, vilipendiando a necessária lesividade a um bem jurídico-penal ${ }^{459}$. A mesma sorte de

\footnotetext{
${ }^{454}$ BECHARA, Ana Elisa Liberatore S. Delitos de..., cit., p. 4.

${ }^{455}$ BECHARA, Ana Elisa Liberatore S. Delitos de..., cit., p. 4.

${ }^{456}$ Sobre o tema, já se ofereceu referência em: SOUZA, Luciano Anderson. Expansão do..., cit., pp. 63-72.

${ }^{457}$ FRANCO, Alberto Silva. Globalização e criminalidade dos poderosos. Revista Brasileira de Ciências Criminais, São Paulo, n. 31, 2000, p. 134. Referido texto foi anteriormente citado expressamente, cf. SOUZA, Luciano Anderson. Expansão do..., cit., p. 71. As críticas à proposta do autor espanhol serão retomadas no capítulo seguinte.

${ }^{458}$ Cf. referido supra, item "2.2.2”. Sobre isso, observa BECHARA: “(...) a adoção de um Direito Penal do comportamento, baseado nos medos sociais e no princípio da precaução, ainda que se advogue a tutela indireta de bens jurídicos supraindividuais, leva ao retrocesso da intervenção penal ao período pré-iluminista, não sendo difícil também a aproximação desse modelo ao relativismo axiológico que deu margem à adoção de sistemas autoritários a exemplo da escola de Kiel. A exigência do requisito básico da ofensividade, alcançado na época da Ilustração, tem raízes históricas mais profundas do que a própria Constituição atual e é imprescindível para a argumentação teleológica no campo do ilícito penal, de forma que renunciar a esse princípio significaria renunciar ao próprio Estado Democrático de Direito e permitir, já num âmbito autoritário, a punição da mera vontade ou da periculosidade". BECHARA, Ana Elisa Liberatore S. Delitos de..., cit., p. 4.

${ }^{459}$ REALE JÚNIOR, Miguel. Instituições de..., cit., p. 277.
} 
críticas vale à proposta de D’ÁVILA, imbuída que está também de relativismo axiológico, para além de reconhecidamente carente do critério de ofensividade.

Por fim, como atentamente nota BECHARA ${ }^{460}$, a reflexão de BOTTINI ${ }^{461}$ ostenta equivocado corte analítico, vez que confunde o conceito de delito cumulativo com um problema causal, pois um mesmo agente atuando repetidamente com um único propósito, ou, ainda, agentes diversos agindo com unidade de desígnios, não representam situações tidas pela doutrina como de cumulatividade delitiva. Nestes casos, o intérprete está diante em realidade de uma causalidade cumulativa.

De fato, a teoria da cumulatividade delitiva não despontou até o presente momento como uma convincente proposição capaz de reconstruir ou substituir a lesividade penal como critério crítico limitador e legitimador da incidência penal. Ainda, ao se punir com pena privativa de liberdade uma ação em si mesma inócua, viola-se o princípio da proporcionalidade $^{462}$. De outro lado, a culpabilidade em sentido amplo é vilipendiada, uma vez que se pune o indivíduo pela ação de terceiros ${ }^{463}$. Neste jaez, insta observar se uma específica análise na seara econômica teria o condão de relativizar esse entendimento.

Do ponto de vista da perspectiva filosófica moral, qual seja, a da questão do free-rider, tampouco melhor sorte desponta em favor da justificação da construção cumulativa. Isso porque, em última análise, a punição criminal a comportamentos em si mesmo não lesivos, para além de toda a crítica referida acima, nada mais consubstancia-se senão que em um sancionamento penal a uma infração de dever ${ }^{464}$, merecendo a isto todas as críticas elencadas no capítulo 2 deste trabalho.

\footnotetext{
${ }^{460}$ BECHARA, Ana Elisa Liberatore S. Delitos de..., cit., p. 4.

${ }^{461}$ BOTTINI, Pierpaolo Cruz. Crimes de..., cit., pp. 242-243.

${ }^{462}$ DIAS, Augusto Silva. "What if..., cit., pp. 333-334; SOUSA, Susana Aires de. Os crimes..., cit., p. 237.

${ }^{463}$ SOUSA, Susana Aires de. Os crimes..., cit., p. 237; BECHARA, Ana Elisa Liberatore S. Delitos de..., cit., pp. 4-5.

464 “(...) além do não atendimento ao princípio da ofensividade levar, nos delitos de acumulação, à exaltação do desvalor da ação em detrimento do desvalor do resultado, de tal modo a dar vida a ilícitos de mera desobediência, parece também não ser possível estabelecer qual é o desvalor da ação do agente, na medida em que se pretende justificar sua punição a partir do prognóstico de possíveis lesões a terceiros". BECHARA, Ana Elisa Liberatore SILVA. Da teoria..., cit., p. 263.
} 
Por outro lado, ainda que se utilizando de um pensamento consoante a teoria dos sistemas de LUHMANN, como nota AUGUSTO SILVA DIAS, não desponta na hipótese a deslealdade comunicativa justificadora de uma censura penal, eis que o freerider não despreza a norma ou mesmo o interesse protegido, apenas procura uma vantagem econômica para si. Segundo o professor de Lisboa:

(...) O "free-rider" é o egoísta que se subtrai ao cumprimento de prestações colectivas para maximizar o interesse próprio, aquele que beneficia, por exemplo, da melhoria da qualidade da água resultante do facto de a maioria das pessoas se abster de lavar a roupa no ribeiro, mas renuncia a fazer o mesmo para economizar gastos. A sua motivação corresponde à do "homo oeconomicus", que pauta sua acção pelos ditames de uma razão instrumental. Ele actua elegendo os meios que lhe permitam aumentar os lucros e diminuir os gastos. Élhe mais ou menos indiferente que os outros respeitem ou não o bem colectivo (...) Sendo assim, a sua motivação egoísta, por si só, não tem o significado de uma deslealdade comunicativa $(. . .)^{465}$.

\title{
3.6. Delitos cumulativos e sua capacidade justificadora da tutela penal econômica
}

Insta verificar, nesse momento, se especificamente no âmbito da delinqüência econômica, concorreriam argumentos capazes de rechaçar de algum modo as críticas até aqui ofertadas à construção cumulativa.

A atividade econômica, como observa JOSÉ DE FARIA COSTA, é, em essência, de repetição. Nas palavras do autor português:

\begin{abstract}
A ninguém escapa o facto de - contrariamente aos crimes, por exemplo, contra as pessoas ou contra a vida - a criminalidade económica ter um potencial de lesão serial infinitamente superior àqueloutras infracções. Com efeito, sabe-se e é imediatamente perceptível que a actividade económico-empresarial é, quase que por sua natureza, de reiteração. Reiteração de processos. Reiteração de decisões. Reiteração na prossecução de objectivos. Ora, este traço de reiteração estende-se a toda actividade e, por conseguinte, também aos comportamentos criminosos. $(\ldots)^{466}$.
\end{abstract}

Assim é que a infração penal econômica factualmente tende à sua reiteração, uma vez que esta é a lógica própria do modo de produção vigente, revelador do perene

${ }^{465}$ DIAS, Augusto Silva. "What if..., cit., p. 337.

${ }^{466}$ COSTA, José de Faria. Direito penal..., cit., pp. 58-59. 
interesse de lucro por parte dos agentes econômicos. Ademais, não apenas se reveste deste mesmo sentido a multiplicação da ação pelo mesmo agente, como também há de se considerar hipoteticamente a possibilidade de sua imitação por grande número de outros agentes.

Exemplificativamente, no caso brasileiro, pode-se pensar no crime de "fazer afirmação falsa ou enganosa, ou omitir informação relevante sobre a natureza, característica, qualidade, quantidade, segurança, desempenho, durabilidade, preço ou garantia de produtos ou serviços", insculpido no artigo 66 da Lei n. 8.078/90, que inclusive veda, em seu $\S 2^{\circ}$, as condutas típicas mistas alternativas descritas na modalidade culposa. Dessa maneira, claramente nota-se que o interesse penalmente tutelado, qual seja, a ordem econômica, que possui, como afirmado, o consumidor como beneficiário último, não se vê minimamente abalado com singela omissão descuidada de um produtor ou um fornecedor de serviços que se esquece da aposição de um dado. Noutras palavras, a confiança do mercado não é significativamente afetada por uma tal conduta. Isto somente poderia vir a ocorrer com a reiteração do agir ou, rememorando-se a máxima de FEINBERG, se todos ou grande parte fizerem o mesmo. Se, v.g., a totalidade ou a maioria dos produtores de pilhas ou de leite deixarem de informar os consumidores sobre a qualidade e durabilidade dos produtos, poderia haver uma generalizada desconfiança coletiva nas suas comercializações, fomentando-se um abalo na ordenação econômica nestes setores.

A singela conjectura formulada ostenta hipótese de vedação que poderia se escorar na teoria da cumulatividade delitiva, servindo a lei penal como instrumento motivador ético-comportamental na seara econômica em situações as quais especificamente não se ofende um bem jurídico penal, ou seja, em ações inofensivas, nas quais sequer se cogita das intenções do agente.

Situação um pouco diversa a se refletir dar-se-ia com, e.g., o crime de "destruir, inutilizar ou danificar matéria-prima ou mercadoria, com o fim de provocar alta de preço, em proveito próprio ou de terceiro", previsto no inciso VIII do artigo $7^{\circ}$ da Lei n. 8.137/90. Dificilmente um singelo ato de um fornecedor de pequeno ou médio porte ocasionaria realmente a alta de preços. Esta somente poderia ser alcançada com a 
reiteração da conduta ou, ainda, se todos ou grande parte fizerem o mesmo. Exatamente por esta razão é que o tipo penal em comento não exige para sua configuração a efetiva provocação de alta de preços e sim o seu simples intuito. Dessa forma, se por um lado o tipo aproxima-se do modelo do delito cumulativo, de outro, afasta-se no aspecto da culpabilidade em sentido amplo, pois aqui se exige um especial fim de agir. Embora dificilmente na prática seja possível comprovar-se o citado aspecto subjetivo.

De todo modo, demonstrada a pertinência do tema na esfera do Direito Penal Econômico, questiona-se, portanto, se uma dita construção justificar-se-ia, mantendo-se legítima a intervenção penal em tais casos. A isto, responde-se negativamente.

O instituto da cumulatividade delitiva não se mostra compatível com o paradigma de um Direito Penal liberal, calcado nas idéias-força da proteção a um bem jurídico fundamental para a existência social, bem como da fundamentação nos princípios da ofensividade, da proporcionalidade e da culpabilidade, critérios limitadores da incidência repressiva penal. Este é o quadro normativo que constitui o fundamento de validade do ramo jurídico-penal nas sociedades democráticas e que não encontra ressonância nos tipos aditivos ${ }^{467}$, atingindo, dessa maneira, sua legitimidade, qualquer que seja o objeto que se procure tutelar.

Nas palavras de SUSANA AIRES DE SOUSA, citando o pensamento de AUGUSTO SILVA DIAS ${ }^{468}$ :

(...) A figura da acumulação seria, desde logo, incompatível com o princípio da ofensividade, uma vez que cada acção singular, considerada em si mesma, é destituída de ofensividade, de dano, que o autor define como a perda ou diminuição do valor de um bem para o seu titular. (...) Nos casos de acumulação, só a soma objectiva com outros contributos singulares pode produzir esse efeito de dano. Logo, a punibilidade da acção cumulativa tem por base a sua disfuncionalidade, o que aponta no sentido da similitude entre estes delitos e o ilícito contra-ordenacional $(. . .)^{469}$.

\footnotetext{
${ }^{467}$ DIAS, Augusto Silva. "What if..., cit., pp. 334-335, passim.

468 “(...) A conduta singular não é, como vimos, ofensiva de um bem, no sentido em que ela própria diminui efectivamente o valor de utilidade do bem para os seus titulares, mas disfuncional em relação ao bem, no sentido em que aumenta a perturbação no ambiente desse bem (...)". DIAS, Augusto Silva. "What if..., cit., p. 320 .

${ }^{469}$ SOUSA, Susana Aires de. Os crimes..., cit., p. 237. Cf. DIAS, Augusto Silva. "What if..., cit., p. 339.
} 
A lógica ínsita à punição criminal a condutas em si mesmas insignificantes, seja, num aspecto, por conta da falta de parâmetros técnicos em uma dogmática jurídica que se pretende consagradora de um Estado Democrático de Direito, seja, por outro, pela mera reprovação penal em nome de uma deslealdade comunicativa por motivos egoísticos, tão-somente ensejam um construção teorética de cerceamento criminal por um modelo de violação de dever, ou de mera desobediência ${ }^{470}$.

Assim, se por um lado a construção dos delitos cumulativos desvela ilegitimidade na seara jurídico-penal, caracterizadora de uma sua utilização como mero instrumento de controle administrativizado ${ }^{471}$, por outro, justamente, desponta como mais adequada ao âmbito do Direito Administrativo, quer por sua função regulatória ou por sua aptidão “(...) a funcionar muito bem como mecanismo de reforço hábil das expectativas normativas, sem que se faça necessário o recurso ao Direito Penal” ${ }^{\text {"472. }}$.

Neste sentido, entendendo que a sistemática teorética do dano cumulativo é adequada ao Direito Administrativo Sancionador, observa SILVA SÁNCHEZ:

(...) o Direito Administrativo sancionador é essencialmente o Direito do dano cumulativo ou, também, do dano derivado da repetição, que dispensa uma valoração do fato específico, requerendo somente uma valoração acerca de qual seria a transcendência global de um determinado gênero de condutas que viesse a ser considerado ilícito. Em outras palavras, a pergunta-chave é "o que aconteceria se todos os intervenientes neste setor de atividade realizassem a conduta $\mathrm{X}$ - quando existe, ademais, uma séria probabilidade de que muitos deles o façam -, caso fosse considerada lícita?"473.

\footnotetext{
${ }^{470}$ DIAS, Augusto Silva. "What if..., cit., pp. 336-337.

${ }^{471}$ BECHARA, Ana Elisa Liberatore S. Delitos de..., cit., p. 3; BECHARA, Ana Elisa Liberatore SILVA. Da teoria..., cit., pp. 265.

${ }^{472}$ BECHARA, Ana Elisa Liberatore S. Delitos de..., cit., p. 5.

${ }^{473}$ SILVA SÁNCHEZ, Jesús-María. A expansão do..., cit., p. 117.
} 


\section{DIREITO ADMINISTRATIVO SANCIONADOR}

SUMÁRIO: 4.1. Introdução; 4.2. A Escola da Frankfurt e o discurso de resistência à expansão do Direito Penal; 4.3. A proposta de WINFRED HASSEMER: o Direito de Intervenção; 4.4. A proposta de SILVA SÁNCHEZ: o Direito Penal de duas velocidades; 4.5. A leitura administrativo-sancionadora no Brasil; 4.5.1. Introdução; 4.5.2. Diferenciação entre o ilícito administrativo e o ilícito penal; 4.5.3. Razões alegadas para a utilização do Direito Administrativo Sancionador; 4.5.4. Propostas para o aperfeiçoamento do Direito Administrativo Sancionador; 4.5.4.1. Adoção do princípio da legalidade; 4.5.4.2. A flexibilização da aferição do elemento subjetivo na hipótese, com uma presunção de dolo; 4.5.4.3. O estabelecimento da solidariedade entre a empresa e seu dirigente na imputação da prática de infração à ordem econômica; 4.5.4.4. A fixação de normas relativas às causas dirimentes escoradas na inexigibilidade de outra conduta; 4.5.4.5. A previsão do erro de tipo e de força maior, a excluir a sanção; 4.5.4.6. O regramento preciso da individualização da sanção; 4.5.4.7. A contemplação de causas de extinção da punibilidade e prescrição sancionatória; 4.5.4.8. Erigimento de um sistema processual adequado, com independência orgânica.

\subsection{Introdução}

Se por um lado há autores das mais diversas feições ideológicas que defendem a intervenção penal na seara econômica, como forma de se equacionar parte dos novéis problemas fruto da pós-modernidade, ou sociedade do risco, dentre os quais é possível citar KLAUS TIEDEMANN, LUIS GRACIA MARTÍN, CARLOS MARTÍNEZBUJÁN PÉREZ, JUAN M. TERRADILLOS BASOCO, JOSÉ FRANCISCO DE FARIA COSTA, etc., por outro, paradigmaticamente, pode-se apontar os integrantes da alcunhada Escola de Frankfurt, notadamente, WINFRIED HASSEMER, WOLFGANG NAUCKE, PETER-ALEXIS ALBRECHT, CORNELIUS PRITTWITZ e FELIX HERZOG, os quais, com variações de nuances, denotam um discurso de resistência à ampliação do espectro jurídico-criminal $^{474}$.

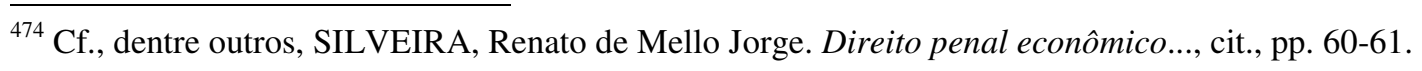


Também com sentido crítico, mas com construções bastante diferenciadas, tem-se a proposta de JESÚS-MARÍA SILVA SÁNCHEZ de dupla velocidade penal (limitativa ao menos no que tange a um Direito Penal identificado como clássico ou tradicional), assim como as idéias de um Direito Administrativo Sancionador, cujos significativos expoentes brasileiros acerca da matéria são MIGUEL REALE JÚNIOR, EDUARDO REALE FERRARI, HELENA REGINA LOBO DA COSTA e FÁBIO MEDINA OSÓRIO, os quais também refletem sobre estudos notadamente de autores espanhóis como JOSÉ CEREZO MIR, MARINO BARBERO SANTOS, LAURA ZÚÑIGA RODRÍGUEZ e ALEJANDRO NIETO GARCÍA, dentre outros, tendo em vista que na Espanha, ao contrário do que se constata na doutrina de outros países europeus, o tema vem ainda até nossos dias sendo objeto de aprofundados estudos.

Muito embora as idealizações destacadas - Escola de Frankfurt, Direito de Intervenção, Direito Penal de duas velocidades e Direito Administrativo Sancionador distanciem-se em proposições, todas têm em comum a busca por soluções legítimas no regramento de atos sociais danosos decorrentes das complexidades da pós-modernidade, distanciando-se das formulações de lege lata lastreadoras de um Direito Penal do risco. Nos casos específicos da Escola de Frankfurt, em geral, e especificamente no ideário brotado em seu contexto, isto é, da construção de um Direito de Intervenção, assim como na hipótese de defesa de um Direito Administrativo Sancionador, inclusive, fundamentalmente, afasta-se do próprio ramo jurídico-criminal como meio de tutela.

Há de se analisar, então, cada pensamento para, ao depois, na presente investigação científica doutoral, uma tomada de postura, quer no sentido de justificar o Direito Penal Econômico, isto é, de entender absoluta ou parcialmente legitimada a utilização da esfera jurídico-penal para fins de tutela da ordem econômica, ou, caso se constate sua ilegitimidade, total ou parcial, para apontamento de uma solução viável com vistas ao equacionamento das condutas econômicas socialmente indesejáveis.

O destaque dado no presente capítulo ao Direito Administrativo Sancionador justifica-se pela maior amplitude da proposta relativamente às demais referidas, assim como pela sua pertinência quanto ao temário, conforme se demonstrará. 


\subsection{A Escola da Frankfurt e o discurso de resistência à expansão do Direito Penal}

A expressão "Escola de Frankfurt" originariamente refere-se a uma tendência crítica de cunho filosófico e sociológico que, a partir do início do século $\mathrm{XX}$, congregou trabalhos de intelectuais de ideologia marxista, como HORKHEIMER, ADORNO, BENJAMIN, MARCUSE, FROMM, HABERMAS e NEUMANN, entre outros, a partir da criação do Instituto de Pesquisas Sociais da Escola de Frankfurt ${ }^{475}$. O sentido empregado no presente trabalho, entretanto, é outro, vez que se atrela àquele que JORGE DE FIGUEIREDO DIAS atribui como primeiramente alcunhado por SCHÜNEMANN, qual seja, o relativo a um grupo, despontado na segunda metade do século passado, de penalistas alemães de origem acadêmica frankfurtiana com pensamento acentuadamente liberal, encabeçados por WINFRIED HASSEMER ${ }^{476}$.

Assim, constata-se que autores como HASSEMER, NAUCKE, ALBRECHT, PRITTWITZ, LÜDERSSEN e HERZOG resistem ao movimento expansionista jurídicocriminal típico da sociedade do risco, partindo da concepção que a liberdade dos cidadãos deve ser resguardada ao máximo. Em consequiência disso, o Direito Penal deve se cingir a um núcleo mínimo, o qual possui como referencial a pessoa humana, sendo certo que isto implica que os tipos penais legítimos são apenas aqueles que se voltam à proteção de bens indispensáveis à pacífica convivência social, como, por exemplo, vida e patrimônio, contra os mais graves atos que os atentem.

Curiosamente, há que se observar que esta denominada Escola de Frankfurt não tem sua existência explicitamente admitida por seus identificados integrantes ${ }^{477}$, muito

\footnotetext{
475 Cf. WIGGERSHAUS, Holf. A Escola de Frankfurt: história, desenvolvimento teórico, significação política. Trad. Lilyane Deroche-Gurgel e Vera de Azambuja Harvey. Rio de Janeiro: Difel, 2006, passim.

${ }^{476}$ Cf. DIAS, Jorge de Figueiredo. O papel..., cit., p. 605.

${ }^{477}$ SILVEIRA, Renato de Mello Jorge. Direito penal econômico..., cit., pp. 60-61, nota 113. Interessante a idéia de que o reconhecimento de uma escola ou tendência jurídica dá-se por contraposição, pois, em face de divergências pontuais de pensamento, dificilmente constata-se uma identificação de filiação a uma corrente dentre os próprios autores identificados como um grupo pelos demais. Neste sentido, cf. JIMÉNEZ DE ASÚA, Luis. Introducción al derecho penal. Ciudad de México: Jurídica Universitária, 2002, v. 1, pp. 115117, e, citando este último, SALVADOR NETTO, Alamiro Velludo. Finalidades da pena: conceito material de delito e sistema penal integral. São Paulo: Quartier Latin, 2009, pp. 55-56.
} 
embora HASSEMER já tenha de certo modo ofertado uma sinalização neste sentido ${ }^{478}$. Contudo, o fato é que a doutrina penal aponta como dita Escola um grupo de pensadores alemães, os quais teriam como característicos comuns sua sede de estudos na cidade germânica de Frankfurt e um pensamento filosófico com balizas políticas de significativo cunho liberal.

No que diz respeito especificamente ao Direito Penal Econômico, há severas objeções desta linha de pensamento, em especial com atenção à antecipação de tutela penal por meio da construção de tipos de perigo abstrato ${ }^{479}$. Em outras palavras, identifica-se no geral a tutela penal da ordem econômica como um aspecto do expansionismo penal das últimas décadas, o qual exacerba a criação de tipos criminais, mormente por construções, ou formas, pouco seguras, como é o caso da formulação de perigo abstrato, que antecipa a resposta penal no sentido de sequer exigir que se constate que um perigo vedado efetivamente se deu, consagrando-se o simbolismo penal.

Dentro do contexto da Escola de Frankfurt, em face das dificuldades apontadas nas construções legislativas e também dogmáticas hodiernas, isto é, do Direito Penal do risco, abarcando-se o discurso que procura o referendar, desponta uma proposta concreta de equacionamento, ofertada por HASSEMER, qual seja, o Direito de Intervenção.

\subsection{A proposta de WINFRIED HASSEMER: o Direito de Intervenção}

Crítico do Direito Penal erigido sob a égide da sociedade do risco, ou seja, da construção jurídico-criminal sem freios que tem por escopo a contenção de novos riscos sociais, privilegiando a prevenção de comportamentos indesejados ou temidos, mormente em nome do combate da criminalidade organizada, ou dos poderosos, em oposição àquela que seria de massas (tradicional, dos delitos de bens individuais), WINFRIED

\footnotetext{
${ }^{478}$ HASSEMER, Winfried. La autocomprensión de la ciencia del derecho penal frente a las exigencias de su tiempo. Trad. María del Mar Diaz Pita. In: MUÑOZ CONDE, Francisco (Coord.). La ciencia del derecho penal ante el nuevo milenio. Valencia: Tirant lo Blanch, 2004, p. 28.

${ }^{479}$ SILVEIRA, Renato de Mello Jorge \& SALVADOR NETTO, Alamiro Velludo. Sarbanes-Oxley-Act e..., cit., p. 197.
} 
HASSEMER reflete sobre a adequação do modelo jurídico-penal forjado neste contexto com aquele que seria o legítimo num Estado Democrático de Direito ${ }^{480}$. HASSEMER parte da premissa que o Direito Penal é incapaz e não tem por tarefa o gerenciamento de riscos na sociedade pós-industrial ${ }^{481}$.

O autor germânico, assim, opõe-se ao Direito Penal do risco, propugnando que o Direito Penal circunscreva-se a uma esfera nuclear, mínima, cingida à punição dos delitos clássicos, de cunho individual, ou ainda coletivos, mas desde que estes estejam necessariamente atrelados ao indivíduo, isto é, tenham-no como referencial ${ }^{482}$ :

Acho que o Direito Penal tem que abrir mão dessas partes modernas que examinei. O Direito Penal deve voltar ao aspecto central, ao Direito Penal formal, a um campo no qual pode funcionar, que são os bens e direitos individuais, vida, liberdade, propriedade, integridade física, enfim, direitos que podem ser descritos com precisão, cuja lesão pode ser objeto de um processo penal normal. (...) Acredito que é necessário pensarmos em um novo campo do direito que não aplique as pesadas sanções do Direito Penal, sobretudo as sanções de privação de liberdade e que, ao mesmo tempo possa ter garantias menores. Eu vou chamá-lo de Direito de Intervenção ${ }^{483}$.

Diante das incompatibilidades verificadas do confronto entre a dogmática penal fruto do desenvolvimento iluminista e os novos interesses sociais criminalmente

${ }^{480}$ HASSEMER, Winfried. Crisis y características del moderno derecho penal. Trad. Francisco Muñoz Conde. Actualidad Penal, Madrid, n. 43, fasc. 2, nov. 1993, pp. 635-646.

${ }^{481}$ Como observa BOTTINI: "Os autores da Escola de Frankfurt apontam que o direito penal é incapaz de conter os novos riscos, e sua função é meramente simbólica e pouco significativa para o enfrentamento dos problemas atuais. O direito penal de hoje, com suas tendências expansivas, é visto como um direito penal da contra-ilustração”. BOTTINI, Pierpaolo Cruz. Crimes de..., cit., p. 99.

482 "Os novos tons soavam muito diferentes. Pense-se no caráter fragmentário do Direito penal e sobretudo no princípio da proteção de bens jurídicos: antes lacunas do que criminalização excessiva e, pelo menos, nenhuma ameaça de pena sem demonstração sólida da necessidade de proteção penal de um interesse humano ameaçado". HASSEMER, Winfried. História das idéias penais na Alemanha do pós-guerra. Trad. Carlos Eduardo Vasconcelos. Revista Brasileira de Ciências Criminais, São Paulo, n. 6, 1994, p. 36. Sobre o pensamento do autor de Frankfurt, observa MACHADO: "Opondo-se a todas as tendências do direito penal do risco, Hassemer defende a redução do direito penal a um direito penal nuclear, formado apenas por delitos de lesão a clássicos bens jurídicos individuais ou a bens jurídicos supra-individuais estritamente vinculados à pessoa, delitos de perigo concreto graves e evidentes e por regras de imputação rígidas e princípios de garantia clássicos. Dessa forma, a proteção aos bens jurídicos supra-individuais em face dos novos riscos tecnológicos seria definitivamente afastada do direito penal, evitando-se, assim, qualquer tentativa de expansão da tutela penal - e, também, não ficaria, simplesmente, a cargo do direito administrativo (...)”. MACHADO, Marta Rodriguez de Assis. Sociedade..., cit., p. 197.

${ }^{483}$ HASSEMER, Winfried. Perspectivas de uma moderna política criminal. Trad. Cezar Roberto Bitencourt. Revista Brasileira de Ciências Criminais, São Paulo, n. 08, p. 49, out.-dez. 1994, pp. 41-51. 
tutelados, HASSEMER propõe que tais interesses sejam regulados por um novo ramo do Direito, qual seja, o Direito de Intervenção. Este novel sistema sancionatório propugnado, segundo seu entendimento, estaria situado entre o Direito Civil ou Administrativo e o Direito Penal.

Não haveria, desta maneira, uma disciplina tão gravosa e rígida para os interesses típicos da pós-modernidade, ensejando, então, ampla descriminalização de condutas. Mas, por outro lado, para que não se verifique a ausência de efetividade da tutela pelos ramos civil ou administrativo, estes se veriam reforçados, por meio de uma intensificação punitiva que os transmutariam num ramo inédito, que o autor denomina de Direito de Intervenção. Este, mais flexível que o Direito Penal e com possibilidade de maior função preventiva com vistas ao gerenciamento de novos riscos fruto do desenvolvimento social, não cominaria, todavia, penas privativas de liberdade. $\mathrm{O}$ preço pago pela mitigação do garantismo seria, assim, a impossibilidade de adoção da sanção prisional.

Embora cheia de significação e sentido, dados pelo tom da crítica voltada ao Direito Penal simbólico da sociedade pós-moderna, o fato é que a proposta de HASSEMER carece de maior precisão, vez que o autor não delineia os contornos do que seria efetivamente o Direito de Intervenção. Destarte, o ideal proposto permanece vago, sem maior concretude, perdendo sua força por carência de uma delimitação mais aprofundada:

(...) Ainda que se apresente como uma alternativa viável de organização legislativa, não nos parece suficientemente amadurecida para ser aplicada ao direito brasileiro. A falta de precisão dos contornos do direito de intervenção, assumida por HASSEMER, poderia ensejar a prática de arbitrariedades, em nome da contenção eficaz de riscos. A exclusão da pena de prisão não significa que as demais sanções possam ser aplicadas sem uma sistemática rígida, que respeite o princípio da legalidade e do devido processo legal. Para isso, faz-se necessária uma discussão mais profunda e reflexiva sobre os parâmetros para a incidência das normas de intervenção, sobre os limites da flexibilidade deste sistema e sobre as condutas sobre as quais suas normas são aplicadas ${ }^{484}$.

${ }^{484}$ BOTTINI, Pierpaolo Cruz. Crimes de..., cit., pp. 100-101. No mesmo sentido, v.g., BECHARA, Ana Elisa Liberatore Silva. Da teoria..., cit., p. 223, nota 45. 
BOTTINI refere-se, ainda, às críticas que a proposta de HASSEMER recebe por supostamente criar duas classes de Direito Penal, eis que o núcleo mais gravoso, com cominação de penas privativas de liberdade, voltar-se-ia aos delinqüentes tradicionais, membros de classes marginalizadas, enquanto que o novo ramo seria uma válvula de escape para os poderosos, ou seja, os criminosos de colarinho branco, os quais estariam infensos à prisão ${ }^{485}$. Curiosamente, dentre tais críticos encontra-se SILVA SÁNCHEZ ${ }^{486}$, o qual propõe a sistemática de bipartição do Direito Penal em duas categorias, em certo sentido bastante aproximada da idealização de HASSEMER.

\subsection{A proposta de SILVA SÁNCHEZ: o Direito Penal de duas velocidades}

No mesmo sentido de HASSEMER, isto é, em face do descompasso verificado do confronto entre a dogmática penal tradicional e os novos interesses da sociedade do risco, muitas vezes complexos e pouco sedimentados, mas criminalmente tutelados, SILVA SÁNCHEZ desenvolve uma proposta particular, qual seja, a criação de um Direito Penal de duas velocidades:

O conflito entre um Direito Penal amplo e flexível (convertido em um indesejável soft law) e um Direito Penal mínimo e rígido - certamente impossível - deve achar assim uma solução no "ponto médio" da configuração dualista. Com efeito, não parece que a sociedade atual esteja disposta a admitir um Direito Penal orientado ao paradigma do "Direito Penal mínimo". Mas isso não significa que a situação nos conduza a um modelo de Direito Penal máximo. A função racionalizadora do Estado sobre a demanda social de punição pode dar lugar a um produto que seja, por um lado, funcional, e por outro lado, suficientemente garantista. Assim, trata-se de salvaguardar o modelo clássico de imputação e de princípios para o núcleo intangível dos delitos, aos quais se assinala uma pena de prisão. ${ }^{487}$.

Assim, segundo este ideário, o equacionamento jurídico das dificuldades advindas da pós-modernidade estaria ainda dentro da categoria do Direito Penal, com seu poder estigmatizante. Contudo, o ramo jurídico-criminal deveria se bipartir. Para os novéis problemas, notadamente difusos, utilizar-se-ia de um Direito Penal menos garantista, de

\footnotetext{
${ }^{485}$ BOTTINI, Pierpaolo Cruz. Crimes de..., cit., p. 101.

${ }^{486}$ SILVA SÁNCHEZ, Jesús-María. A expansão do..., cit., p. 143. Citando-o expressamente, cf. BOTTINI, Pierpaolo Cruz. Crimes de..., cit., p. 101, nota 36.

${ }^{487}$ SILVA SÁNCHEZ, Jesús-Maria. A expansão..., cit., pp. 145-146.
} 
cunho flexível, ou relativizado, mas que não cominaria pena privativa de liberdade; para os interesses tradicionais, bens jurídicos individuais clássicos, como vida e patrimônio, prevaleceria o vetor liberal garantista, com todo seu rigor técnico.

De acordo com o autor espanhol, então, a solução dualista usa da capacidade intimidatória do Direito Penal - que nenhuma outra subdivisão do Direito possui -, mas sem o sacrifício dos direitos individuais. A função simbólica do Direito Penal justificaria sua utilização em lugar de qualquer outro ramo jurídico.

O ideário de SILVA SÁNCHEZ, deste modo, se por um lado aproxima-se em alguma medida da proposta de HASSEMER, no sentido de não se utilizar da sanção prisional $^{488}$ para se coibir os novos riscos sociais, por outro, afasta-se dela em essência, pois mantém a tutela dos inéditos interesses difusos no âmbito jurídico-criminal. Ou seja, não se manifesta o autor espanhol pela redução do Direito Penal a um patamar mínimo ${ }^{489}$. Por esta razão, compreende-se a teoria de SILVA SÁNCHEZ como expansionista, isto é, que entende que o Direito Penal deve fazer frente às situações danosas no bojo das novas complexidades sociais ${ }^{490}$.

Há que se observar, ainda, que na segunda edição de sua obra sobre a expansão do Direito Penal ${ }^{491}$, SILVA SÁNCHEZ acrescenta ao fim um capítulo o qual versa sobre uma possível "terceira velocidade" penal, identificada pelo autor como um Direito Penal "de emergência", aproximado à questão do "Direito Penal do inimigo"492. Esta nova velocidade seria a hipótese de haver, em situações de absoluta necessidade,

\footnotetext{
${ }^{488}$ Para SILVA SÁNCHEZ, “(...) o problema não é tanto a expansão do Direito Penal em geral, senão especificamente a expansão do Direito Penal da pena privativa de liberdade". SILVA SÁNCHEZ, JesúsMaria. A expansão..., cit., p. 139.

489 “(...) SILVA SÁNCHEZ não se manifesta pela redução do direito penal a um patamar mínimo, como propõe a Escola de Frankfurt, mas defende um sistema que faça frente aos novos riscos e que, ao mesmo tempo, respeite os princípios de um Estado Democrático de Direito: o direito penal de duas velocidades. Para este autor, a expansão do direito penal atual deve vir acompanhada da redução do rigor das sanções: logo, a flexibilização de princípios tradicionais será admitida quando correspondida pela generalização das penas pecuniárias, privativas de direitos ou da reparação penal, em lugar da privação de liberdade". BOTTINI, Pierpaolo Cruz. Crimes de..., cit., p. 102.

${ }^{490}$ SOUZA, Luciano Anderson. Expansão do..., cit., p. 62 e ss.

${ }^{491}$ Referido livro é a única edição traduzida ao português: SILVA SÁNCHEZ, Jesús-Maria. A expansão..., cit., passim.

${ }^{492}$ SILVA SÁNCHEZ, Jesús-Maria. A expansão..., cit., p. 148-151.
} 
subsidiariedade e eficácia, em um contexto emergencial, um alargamento da fronteira penal, cominando-se pena privativa de liberdade em concorrência "com uma ampla relativização de garantias político-criminais, regras de imputação e critérios processuais" $" 493$. Embora o autor critique a postura legislativa quando tal se dê de forma cômoda e irrefletida, o que prognostica como tendência, acaba por admiti-la como um mal necessário nas hipóteses excepcionais.

No que diz respeito especificamente ao Direito Penal Econômico, o autor propõe uma relativização controlada das regras de imputação e de princípios políticocriminais:

(...) a propósito do Direito Penal econômico, por exemplo, caberia uma flexibilização controlada das regras de imputação (a saber, responsabilidade penal das pessoas jurídicas, ampliação dos critérios de autoria ou da comissão por omissão, dos requisitos de vencibilidade do erro etc.), como também dos princípios político-criminais (por exemplo, o princípio da legalidade, o mandato de determinação - que esses princípios admitem uma graduação ou demonstra a diferente taxatividade de uns e outros tipos penais, o diverso alcance das remissões normativas, o maior ou menor recurso a elementos valorativos etc. ou o princípio da culpabilidade) $)^{494}$.

A proposta do professor de Barcelona representa, entretanto, uma quebra sistêmica ${ }^{495}$, além de consagrar o expansionismo penal típico da sociedade do risco. Para BECHARA, “(...) constitui um discurso eufemista, que, mediante a troca de rotulagem, acaba por pretender a justificação da flexibilização da intervenção estatal repressiva, convertendo-a em instrumento autoritário de controle social” ${ }^{\natural 96}$.

A desfiguração dos contornos liberais do Direito Penal, caracteres representativos de sua essência, segundo aqui se entende, tais como as regras de atribuição de um fato a seu autor (imputação) e os princípios basilares que o compõem, como da

\footnotetext{
493 SILVA SÁNCHEZ, Jesús-Maria. A expansão..., cit., p. 148.

${ }^{494}$ SILVA SÁNCHEZ, Jesús-Maria. A expansão..., cit., pp. 145-146.

${ }^{495}$ BECHARA, Ana Elisa Liberatore S. Delitos de..., cit., p. 4. Cf., ainda, COSTA, que observa: “Abandonar uma única teoria do delito - das maiores garantias desenvolvidas pela tradição do direito penal - significa, de certo, um enorme anacronismo". COSTA, Helena Regina Lobo da. Proteção ambiental..., cit., p. 192.

${ }^{496}$ BECHARA, Ana Elisa Liberatore Silva. Da teoria..., cit., p. 226.
} 
legalidade, da taxatividade ou da culpabilidade, culminam por exigir algo diverso do Direito Penal.

Ademais, conforme assinala com propriedade HELENA REGINA LOBO DA COSTA, indicando que a persecução penal já é por si infamante:

O mais grave defeito de sua proposta repousa em identificar a aplicação da pena privativa de liberdade com o sistema de garantias do direito penal. As garantias do direito penal não têm fundamento apenas no fato de que por seu intermédio pode-se aplicar a pena privativa de liberdade. Tais garantias se dirigem a todo o sistema penal, que de forma global representa um ataque aos direitos fundamentais. O inquérito policial, as medidas cautelares, o próprio processo penal e a aplicação de qualquer pena, seja ela privativa de liberdade ou não, já constituem um gravame aos direitos fundamentais. Por essa razão não se pode concordar com o autor quando afirma que o problema é a expansão do direito penal da pena privativa de liberdade, e não simplesmente do direito penal $^{497}$.

Do mesmo modo que a construção de HASSEMER, essa proposta doutrinária procura uma solução para os rumos do Direito Penal da sociedade do risco, tendo, portanto, o mérito da necessária reflexão que o importante tema enseja ${ }^{498}$. Todavia, se o ideário do professor de Frankfurt pode ser criticado pela carência de profundidade da proposta ou, ainda, por possivelmente dar azo a um Direito Penal de duas classes, referendando uma injustiça social, a do autor espanhol certamente perpetra esta última

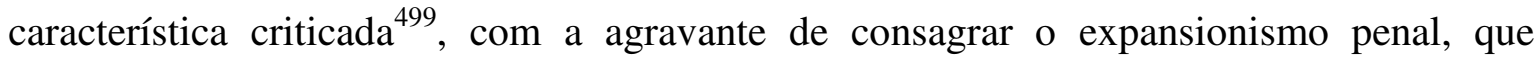
cerceia a liberdade humana não apenas no seu aspecto de ir e vir.

Quanto à possível terceira velocidade penal, a sua admissão ainda que um tanto tímida por parte do professor espanhol, além de se revelar de certo modo contraditória com a proposta até então defendida ${ }^{500}$, carece de maior justificação, sendo

\footnotetext{
${ }^{497}$ COSTA, Helena Regina Lobo da. Proteção penal..., cit., p. 214.

498 “As propostas de HASSEMER e SILVA SÁNCHEZ são demonstrações inequívocas da perplexidade do jurista diante dos novos riscos”. BOTTINI, Pierpaolo Cruz. Crimes de..., cit., p. 103.

499 Para ALBERTO SILVA FRANCO, a adoção da concepção de SILVA SÁNCHEZ consagraria essa desigualdade, pois "o poderoso receberia um prêmio, apesar da minimização do processo garantístico, e o fraco, uma pena privativa de liberdade, não obstante disponha de garantias plenas...”. FRANCO, Alberto Silva. Globalização e..., cit., p. 134.

${ }^{500}$ Pois justamente afasta, ainda que em caráter excepcional, tudo aquilo que até então havia sido o alegado objeto de preocupação em preservar (garantismo penal em face da pena de prisão, num contexto de sociedade do risco). Em sentido contrário, COSTA entende que o duplo sistema estanque abre caminho para uma terceira forma: COSTA, Helena Regina Lobo da. Proteção penal..., cit., p. 214.
} 
verdadeiramente vaga. Ademais, a ela dirigem-se as mesmas críticas enunciadas à proposta funcionalista extremada de JAKOBS, no sentido de vilipendiar os contornos liberais legitimadores de uma incriminação.

\subsection{A leitura administrativo-sancionadora no Brasil}

\subsubsection{Introdução}

As principais idéias relativas ao Direito Administrativo Sancionador ${ }^{501}$ no âmbito brasileiro são devidas, notadamente, a MIGUEL REALE JÚNIOR, EDUARDO REALE FERRARI e HELENA REGINA LOBO DA COSTA, docentes da Faculdade de Direito da Universidade de São Paulo, assim como ao administrativista FÁBIO MEDINA OSÓRIO ${ }^{502}$.

Os pensamentos revelados pelos citados autores nacionais têm em comum a coerência metodológica liberal e a consciência de que o Direito Administrativo Sancionador é um ideário normativo em construção, cuja adoção, não obstante, gera importantes conseqüências para os limites horizontais do Direito Penal brasileiro.

Partindo da premissa que não há diferença substancial entre a norma penal e a administrativo-sancionadora ${ }^{503}$, faz-se um discurso de lege ferenda, defendendo-se, em

\footnotetext{
${ }^{501}$ Entende-se por Direito Administrativo Sancionador o “(...) conjunto de normas jurídicas que disciplinam o exercício do poder sancionador por parte da Administração Pública”, consoante definição de PEREÑA PINEDO, Ignacio (Coordinación). Manual del derecho administrativo sancionador. Navarra: Ministerio de Justicia: Aranzadi, 2005, p. 117 (tradução livre).

${ }^{502}$ Dentre os trabalhos principais dos autores citados relativamente ao tema em foco estão: REALE JÚNIOR, Miguel. Despenalização no direito penal econômico: uma terceira via entre o crime e a infração administrativa? Revista Brasileira de Ciências Criminais, São Paulo, v. 7, n. 28, pp. 116-129, out./dez. 1999; REALE JÚNIOR, Miguel. Ilícito administrativo e o jus puniendi geral. In: PRADO, Luiz Regis (Coordenação). Direito penal contemporâneo: estudos em homenagem ao professor José Cerezo Mir. São Paulo: Revista dos Tribunais, 2007, pp. 93-100; FERRARI, Eduardo Reale. Legislação penal..., cit., p. 253306; FERRARI, Eduardo Reale. A ilegitimidade da criminalização de condutas atentatórias ao meio ambiente. In: ANDRADE, Manuel da Costa et all. Liber discipulorum para Jorge de Figueiredo Dias. Coimbra: Coimbra, 2003, pp. 1185-1203; COSTA, Helena Regina Lobo da. Proteção penal..., cit., pp. 215245; OSÓRIO, Fábio Medina. Direito administrativo sancionador. São Paulo: Revista dos Tribunais, 2000, passim.

${ }^{503}$ REALE JÚNIOR, Miguel. Ilícito administrativo..., cit., p. 93 e ss.; FERRARI, Eduardo Reale. Legislação penal..., cit., p. 261; OSÓRIO, Fábio Medina. Direito administrativo..., cit., p. 102; COSTA, Helena Regina Lobo da. Proteção penal..., cit., p. 202.
} 
linhas gerais, na seara econômica, em face da subsidiariedade penal, uma utilização primeira do Direito Administrativo na tutela da ordem econômica, mas com nuances específicas - daí a especificação de "sancionador" -, vez que preciso uma maior independência dos órgãos repressores do Poder Executivo, principalmente, e Legislativo $^{504}$, assim como a delimitação restritiva da forma de atuação repressora.

Neste sentido, de fato, muito pouco se diria com a simples sustentação de mera descriminalização de condutas e transferência de tutela para o Direito Administrativo da delinqüência econômica ${ }^{505}$. Aliás, caso adotado, referido pensamento poderia se revelar enormemente dificultoso, tendo em vista que o arbítrio estatal fomentado pelo Direito Penal apenas mudaria de etiquetamento ${ }^{506}$ ou mesmo se gravaria em certos $\operatorname{casos}^{507}$, tãosomente não se cominando a sanção prisional.

Em outras palavras, nota-se que a mera punição administrativa de condutas socialmente indesejadas, sem garantias como as reveladas pelo ramo jurídico-penal, tais como aquelas trazidas pelos princípios da legalidade, proporcionalidade, culpabilidade, etc., pode em certas situações até ser mais gravosa à cidadania que a repressão penal ${ }^{508}$, pois tem o condão de cercear de modo arbitrário a liberdade dos cidadãos em todos os demais aspectos que não o relacionado com o direito de ir e vir, que, notadamente, não é o único passível de atingimento com a resposta penal. Esse, inclusive, é o sentido crítico de

\footnotetext{
${ }^{504}$ A defesa de maior independência do Poder Legislativo justifica-se, no caso brasileiro, em decorrência, por exemplo, da forma de nomeação de integrantes do Conselho Administrativo de Defesa Econômica - CADE -, que são sabatinados por este Poder. Cf. FERRARI, Eduardo Reale. Legislação penal..., cit., p. 303.

$505 \mathrm{O}$ que de fato não é o sustentado por citados autores. Relativamente aos crimes ambientais, escreve COSTA: "Por outro lado, tampouco se sugere uma mera transferência de condutas do direito penal para o direito administrativo. Deve-se partir de uma estratégia global, que reflita também sobre a efetividade de medidas de prevenção. Não é à toa que os princípios da precaução e da prevenção atuam no direito ambiental (...)”. COSTA, Helena Regina Lobo da. Proteção penal..., cit., pp. 185-186.

${ }^{506}$ Neste sentido, SANTANA VEGA, Dulce María. La protección penal de los bienes jurídicos colectivos. Madrid: Dikinson, 2000, p. 121, nota 82; ZÚÑIGA RODRÍGUEZ, Laura. Relaciones entre derecho penal y derecho administrativo sancionador ¿Hacia una "administrativización" del derecho penal o una "penalización" del derecho administrativo sancionador? In: NIETO MARTÍN, Adán (Coordinador). Homenaje al dr. Marino Barbero Santos in memoriam. Cuenca: Ediciones de la Universidad de Castilla-La Mancha: Ediciones de la Universidad de Salamanca, 2001, p. 1441. Ainda, citando a primeira, v. BECHARA, Ana Elisa Liberatore Silva. Da teoria..., cit., p. 245, e a última, COSTA, Helena Regina Lobo da. Proteção penal..., cit., p. 207, e REALE JÚNIOR, Miguel. Ilícito administrativo..., cit., p. 96.

${ }_{507}$ Para BECHARA, “(...) o direito administrativo sancionador pode, se mal-elaborado e interpretado, constituir um direito repressivo pré-beccariano". BECHARA, Ana Elisa Liberatore Silva. Da teoria..., cit., p. 245.

${ }^{508}$ REALE JÚNIOR, Miguel. Ilícito administrativo..., cit., p. 95.
} 
certos autores portugueses nos dias atuais, em face do desvirtuamento ocorrido naquele ordenamento no que diz respeito aos delitos de mera ordenação social ${ }^{509}$.

Cientes desta possibilidade de transmutação de endereço da arbitrariedade, os autores nacionais em comento defendem, ao revés, uma determinada utilização do Direito Administrativo, aliando eficiência com amplo respeito às garantias individuais, independência de atuação e assecuração de similitude ao Direito Penal no que pertine à sua construção, criando-se, por exemplo, dentre outras proposições, uma Parte Geral para o Direito Administrativo Sancionador, e delimitando-se uma precisa metodologia interpretativa.

Dessa forma, longe de ser um ideário carente de maior concretude, como se poderia formular criticamente relativamente a propostas como a do Direito de Intervenção de HASSEMER, lastreada na experiência estrangeira, a idealização doutrinária brasileira revela-se robusta e coerente com uma vertente iluminista, de eficaz tutela da ordem econômica sem perder de vista as garantias à dignidade da pessoa humana, vetores previstos na Constituição da República Federativa do Brasil.

Cuidar-se-á, assim, neste topos, de detalhes dessa relevante proposta nacional, a qual, sem perder de vista o sólido referencial estrangeiro, quer em termos doutrinários ou legislativos, reflete especificamente acerca do ordenamento pátrio, de modo a consubstanciar-se em uma destacada construção com consectários significativos no que diz respeito ao Direito Penal Econômico brasileiro.

\subsubsection{Diferenciação entre o ilícito administrativo e o ilícito penal}

Primeiramente, consoante pressuposto fundamental dos autores brasileiros em foco, insta se verificar se haveria uma diferença ontológica, normativa ou meramente formal entre o ilícito administrativo e o ilícito penal. Referida verificação é essencial à questão, tendo em vista que, se a diferenciação for de cunho ontológico, há de se aferir

${ }^{509}$ Cf., dentre outros, BRANDÃO, Nuno. Questões contra-ordenacionais suscitadas pelo novo regime legal da medição de seguros. In: Direito penal económico e europeu: textos doutrinários. Coimbra: Coimbra, 2009, v. III, p. 721 e ss. 
quais caracteres materiais possuem o condão de apartar uma construção de outra, ou, por outro lado, se a distinção for de viés normativo, cumpre constatar os requisitos formais e materiais para uma elaboração legislativa válida. Por fim, caso o critério seja meramente formal, forçoso não apenas identificá-lo, como também refletir sobre as conseqüências da adoção deste critério.

O debate em torno da questão inicia-se, conforme explica $\operatorname{COSTA}^{510}$, na segunda metade do século XIX, em terras germânicas. Muito embora o Código Penal do Império (Reichsstrafgesetzbuch), de 1871, não fizesse qualquer distinção, identificando apenas o que seria delito, a doutrina alemã já debatia o tema. A evolução deste debate gerou, no início da centúria passada, uma obra emblemática, de JAMES GOLDSCHMIDT, intitulada Das Verwaltungsstrafrecht ${ }^{511}$, que identificava uma diferenciação qualitativa entre os entes. Nesse sentido, em linhas gerais, o ilícito penal seria a ação que causa ofensa a um bem jurídico, enquanto o ilícito administrativo corresponderia ao não-atendimento de uma prescrição administrativa.

Em que pese o debate gerado a partir desta última obra, por influência de EBERHARD SCHMIDT acabou por prevalecer na legislação penal econômica alemã de $1949^{512}$ o critério formal, o que se seguiu em leis posteriores, dos anos 50, 60 e 70. Por fim, nos dias atuais, apesar de posições doutrinárias diversas - com destaque para NAUCKE, que faz uma diferenciação qualitativa -, predominam as teorias quantitativas. A jurisprudência constitucional da Alemanha, não obstante, adotou o posicionamento de que o ilícito administrativo integra o Direito Penal, consagrando, então, uma teoria mista, muito criticada ${ }^{513}$.

\footnotetext{
${ }^{510}$ A referência histórica ora apresentada parte das precisas descrições de COSTA e BECHARA: cf. COSTA, Helena Regina Lobo da. Proteção penal..., cit., p. 192 e ss.; BECHARA, Ana Elisa Liberatore Silva. Da teoria..., cit., p. 247 e ss.

${ }^{511} \mathrm{O}$ título desta obra pode ser traduzido de forma livre como $O$ Direito Penal Administrativo.

${ }^{512}$ DIAS, Jorge de Figueiredo. O movimento da descriminalização e o ilícito de mera ordenação social. In: INSTITUTO DE DIREITO PENAL ECONÓMICO E EUROPEU - FACULDADE DE DIREITO DA UNIVERSIDADE DE COIMBRA. Direito penal..., cit., p. 21; COSTA, Helena Regina Lobo da. Proteção penal..., cit., p. 193.; BECHARA, Ana Elisa Liberatore Silva. Da teoria..., cit., p. 249.

${ }^{513}$ COSTA, Helena Regina Lobo da. Proteção penal..., cit., pp. 193-196.
} 
$\mathrm{Na}$ Itália, a legislação de 1981 produziu ampla descriminalização econômica ${ }^{514}$, a partir de critérios formais, sendo este o entendimento que prevalece na doutrina daquele país ${ }^{515}$. Neste sentido, sinaliza-se nesta específica alteração legislativa, a ausência de relação com a importância do bem jurídico, circunscrevendo-se a distinção a critérios de política legislativa, como nota REALE JÚNIOR ${ }^{516}$.

Na Espanha, por sua vez, o debate permanece rico, com grande produção doutrinária até os dias que correm. A tese majoritária no país é a de que existe um ius puniendi geral do Estado, sendo que a diferença entre os ilícitos administrativo e penal é encontrada na sanção (tese quantitativa, que possui como expoente doutrinário, e.g., CEREZO MIR) $)^{517}$.

Entre os autores de língua espanhola, divergem deste posicionamento, por exemplo, SILVA SÁNCHEZ ${ }^{518}$ e GARCÍA CAVERO ${ }^{519}$, entendendo que a distinção não

${ }^{514}$ FERRARI nota como uma grande vantagem dessa alteração legal italiana a possibilidade de se poder responsabilizar as pessoas jurídicas pela infração econômica, cf. FERRARI, Eduardo Reale. Legislação penal..., cit., p. 297.

${ }_{515}$ COSTA, Helena Regina Lobo da. Proteção penal..., cit., pp. 193-197.

516 "Os processos de despenalização ocorridos na Itália e na França bem demonstram como a escolha da via penal ou da via administrativa nada tem a ver com a importância do bem jurídico, tratando-se antes de uma escolha com base na conveniência política deste ou daquele caminho, com vista a melhor alcançar os fins preventivos e retributivos de um direito punitivo que cada vez mais se faz único (...)”. REALE JÚNIOR, Miguel. Ilícito administrativo..., cit., p. 93. A seguir, o autor observa: "Como assinala Alejandro Nieto, efetivamente a doutrina e a jurisprudência italianas consagram a mera diferença normativa entre os ilícitos, conforme claramente explicita decisão do Tribunal de Ravenna de 1980, segundo a qual a distinção entre delito e ilícito administrativo é apenas normativa e não estrutural, pois ainda que a escolha entre situar determinado fato em uma ou outra esfera possa decorrer da gravidade da agressão, a opção decorre 'da decisão discricionária fundada sobre critérios de política legislativa”. REALE JÚNIOR, Miguel. Ilícito administrativo..., cit., p. 94.

517 COSTA, Helena Regina Lobo da. Proteção penal..., cit., pp. 197-201. No mesmo sentido, observa MANUEL GÓMEZ TOMILLO: "A tese atualmente majoritária defende que ambos os fenômenos possuem a mesma natureza, aceite-se ou não sem reservas a tese quantitativa. Independentemente das reservas que se possam formular a tal ponto de vista, a conclusão inevitavelmente associada a ele, a qual devemos manter aqui, é que a infração penal e a infração administrativa seriam essencial, material, substancialmente idênticas". GÓMEZ TOMILLO, Manuel. Derecho administrativo sancionador. Parte general. Teoría general y práctica del derecho penal administrativo. Navarra: Aranzadi, 2008, pp. 68-70 (tradução livre).

518 "A perspectiva que se centra somente no injusto e sua conformação para distinguir o âmbito do penal e do administrativo é, a meu juízo, errônea. Por isso era errônea a teoria clássica de base ética. Mas também resulta incompleta a moderna teoria da diferenciação (meramente) quantitativa. Com efeito, o decisivo da referida diferenciação não é (somente) a configuração do injusto, senão os critérios desde os quais se contempla, os critérios de imputação desse injusto e as garantias de diverso signo (formais e materiais) que rodeiam a imposição de sanções ao mesmo. A esse respeito, é evidente que a sujeição a um juiz é uma diferença qualitativa, como é a impossibilidade de que administração imponha sanções privativas de liberdade. Tais garantias especiais, que rodeiam o penal e que têm a ver com a repercussão comunicativosimbólica da afirmação de que concorre uma 'infração penal', convergem favoravelmente à idéia de que 
é meramente quantitativa, e sim qualitativa, e NIETO GARCÍA ${ }^{520}$, para quem a diferença é normativa $^{521}$.

Merece particular menção, ainda no contexto da verificação do entendimento prevalente nos países de maior proximidade à nossa doutrina, da realidade portuguesa, quer pela particularidade da experiência legislativa, quer pela significativa produção doutrinária sobre o tema.

Influenciada pela lei alemã, estudada por EDUARDO CORREIA, professor de Coimbra o qual se tornou ministro da Justiça em 1979, oportunidade em que atuou diretamente pela edição do Decreto-Lei n $n^{0} 232 / 79$, a legislação portuguesa promoveu ampla descriminalização econômica, criando o regime do direito de mera ordenação social, ou das contra-ordenações. Conforme DIAS:

O ilícito de mera ordenação social, como disse, foi entre nós pela primeira vez legalmente consagrado no Decreto-Lei no 232/79, de 24 de Julho, ainda aqui por directa actuação do Prof. Dr. EDUARDO CORREIA como Ministro da Justiça. Diploma este, acentue-se, que ia inclusivamente mais além do que o que fora a legislação da Alemanha Ocidental entre 1952 e 1975 (data em que aí começou a vigorar o novo Código Penal). Pois enquanto esta, ao lado da categoria extrapenal das Ordnungswidrigkeiten, manteve até 1975 a categoria especificamente penal das Übertretrungen, o Decreto-Lei $n^{\circ} 232 / 79$ eliminou sem resto a categoria das contravenções puníveis com pena de multa, ao estabelecer no art.

procede introduzir uma perspectiva de diferenciação qualitativa que há de ter reflexo, sobretudo, na forma de entender a lesividade de uma e outra classe de infrações e nos critérios utilizados para sua imputação". SILVA SÁNCHEZ, Jesús-Maria. A expansão..., cit., p. 116. A seguir o autor conclui que o fator decisivo da distinção é o critério teleológico, vez que o Direito Penal persegue a proteção concreta de bens jurídicos, enquanto o Direito Administrativo Sancionador tem por escopo o "reforço da ordinária gestão da administração”. SILVA SÁNCHEZ, Jesús-Maria. A expansão..., cit., p. 116.

${ }^{519}$ GARCÍA CAVERO, Percy. Derecho penal económico: parte general. Tomo I. Lima: Grijley, 2007, p. 123 e ss. Para o autor, “(...) Em nossa compreensão de bem jurídico penalmente protegido, por exemplo, deve ficar claro que o Direito penal econômico não deve restabelecer todo abalo de expectativas derivadas das estruturas do sistema econômico, senão apenas aquelas expectativas cuja vigência resulta indispensável para a manutenção da identidade essencial da sociedade na economia. Por outro lado, para a manutenção do funcionamento de aspectos que simplesmente dão uma ordem ao sistema econômico global ou de questões acessórias do sistema, resultarão suficientes os mecanismos de reestabilização do próprio sistema econômico ou os dispositivos jurídicos extrapenais do Direito administrativo sancionador. O caráter essencial das expectativas restabelecidas por meio do Direito penal marca uma diferença qualitativa com o Direito administrativo sancionador, o que explica, entre outras coisas, que este último recorra fundamentalmente a mecanismos de reestabilização de caráter cognitivo como a apreensão, medidas preventivas de segurança, etc.”. GARCÍA CAVERO, Percy. Derecho penal..., cit., p. 124 (tradução livre).

${ }^{520}$ NIETO GARCÍA, Alejandro. Derecho administrativo sancionador. Madrid: Tecnos, 2008, p. 152 e ss.

${ }^{521}$ SILVA SÁNCHEZ e NIETO GARCÍA são também citados por COSTA, cf. COSTA, Helena Regina Lobo da. Proteção penal..., cit., pp. 198-200. Ainda, SILVA SÁNCHEZ e GARCÍA CAVERO são referidos quanto ao tema por GÓMEZ TOMILLO, Manuel. Derecho administrativo..., cit., p. 58. 
$1^{\circ}$-3 que "são equiparáveis às contra-ordenações as contravenções ou transgressões previstas pela lei vigente a que sejam aplicadas sanções pecuniárias". Logo, porém, o Decreto-Lei no 411-A/79, de 1 de Outubro, revogou o citado art. $1^{\circ}-3$ do Decreto-Lei $n^{\circ} 232 / 79$, impedindo deste modo que se consumasse a preconizada transformação, em bloco e automática, das contravenções vigentes e puníveis só com multa em contra-ordenações.

Em que pese poucos meses após sua edição o Decreto-Lei 232/79 tenha sido alterado de modo a parcialmente limitar o alcance de sua disciplina, houve sua ab-rogação apenas em 1982, com a promulgação do Decreto-Lei 433, ainda em vigor, mas com alterações sofridas em 1989, 1995 e 2001. Tais últimas modificações, note-se, em busca de uma maior assecuração dos direitos fundamentais dos imputados, culminaram por verdadeiramente desfigurar o modelo estabelecido em 1979, havendo, em muitos aspectos, retorno ao modelo penal ${ }^{522}$.

Muito embora a lei portuguesa diferencie o ilícito penal e o contraordenacional de maneira formal, uma vez que o artigo $1^{\circ}$ do Decreto-Lei $n^{\circ} 433$ estabelece que "Constitui contra-ordenação todo o facto ilícito e censurável que preencha um tipo legal no qual se comine uma coima”, em termos doutrinários, desde os estudos de EDUARDO CORREIA, e até a atualidade, com destaque para o pensamento de JORGE DE FIGUEIREDO DIAS, prevalece a compreensão de que haveria uma distinção material entre os ilícitos.

Assim é que CORREIA propugnava que a diferenciação estaria num plano ético-jurídico, diretamente fundamentador do ilícito penal ${ }^{523}$. No caso do ilícito contraordenacional, por sua vez, estar-se-ia diante de um mandamento eticamente neutro ${ }^{524}$. Em sentido similar, DIAS entende que o desvalor da conduta aponta, de um lado, para

522 “(...) O DL 232/79 foi depois revogado e substituído pelo DL 433/82, de 27-10, que instituiu o novo regime geral do direito de mera ordenação social e do respectivo processo. Este diploma foi depois reformulado - em pontos pouco significativos - pelo DL 356/89, de 17-10, e posteriormente pelo DL 244/95, de 14-9, e pela L 109/2001, de 24-12. Reformulação, a destes últimos diplomas, que pretende cobrir-se com a necessidade de uma mais consistente defesa dos direitos e garantias dos argüidos, mas que, em muitos pontos, se aproxima lamentavelmente de uma 'contra-revolução contra-ordenacional', a sugerir um regresso aos tempos passados do modelo (penal e processual penal) das contravenções”. DIAS, Jorge de Figueiredo. Direito Penal: parte geral: tomo I: questões fundamentais: a doutrina geral do crime. São Paulo: Revista dos Tribunais; Coimbra: Coimbra Editora, 2007, pp. 158-159.

${ }^{523}$ CORREIA, Eduardo. Direito penal e direito de mera ordenação social. In: INSTITUTO DE DIREITO PENAL ECONÓMICO E EUROPEU - FACULDADE DE DIREITO DA UNIVERSIDADE DE COIMBRA. Direito penal económico e europeu: textos doutrinários. Coimbra: Coimbra, 1998, V. I, p. 9.

${ }^{524}$ CORREIA, Eduardo. Direito penal..., cit., p. 10. 
identificação de um ilícito penal, uma ação axiológico-socialmente relevante, enquanto que, de outro, para reconhecimento de um ilícito de mera ordenação social, uma ação axiológico-socialmente neutra ${ }^{525}$.

$\mathrm{Na}$ doutrina nacional, prevalece o entendimento de que não há diferença substancial entre a norma penal e a administrativo-sancionadora ${ }^{526}$, vez que há um ius puniendi geral do Estado, o qual se revela pela faceta penal ou administrativa.

Desta feita, a proteção pela via penal ou pela via administrativa não se escora na eventual importância do bem jurídico tutelado ${ }^{527}$ e sim, genericamente, em critérios de conveniência política e eficácia social.

$\operatorname{COSTA}^{528}$, no Brasil, assim como NIETO GARCÍA ${ }^{529}$, na Espanha, observa com propriedade que o crime não existe como realidade, sendo produto de uma definição -

\footnotetext{
${ }^{525}$ Segundo o catedrático de Coimbra: "Já se pensou - e continua a pensar-se, na Alemanha mesmo predominantemente - em negar a possibilidade de determinação material do ilícito penal e do ilícito de mera ordenação social na base de não poder reconhecer-se a existência de um ilícito ético-socialmente indiferente, mesmo que ele seja de 'mera' ordenação social. Quem sustente esta impossibilidade tem, quanto a nós, razão. Mas já a não tem quando daqui pretenda concluir pela impossibilidade de delimitação material entre os dois ilícitos. Necessário é que a perspectiva da 'indiferença ético-social' se dirija não imediatamente aos ilícitos que supõem já realizada a valoração legal -, mas às condutas que os integram. Existem na verdade condutas às quais, antes e independentemente do desvalor da ilicitude, corresponde, e condutas às quais não corresponde um mais amplo desvalor moral, cultural ou social. A conduta, independentemente da sua proibição legal, é no primeiro caso axiológico-socialmente relevante, no segundo caso axiológicosocialmente neutra. $\mathrm{O}$ que no direito de mera ordenação social é axiológico-socialmente neutro não é o ilícito, mas a conduta em si mesma, divorciada da proibição legal; sem prejuízo de, uma vez conexionada com esta, ela passar a constituir substrato idôneo de um desvalor ético-social. É este o critério decisivo que está na base do princípio normativo fundamentador da distinção material entre ilícito penal e ilícito de mera ordenação social”. DIAS, Jorge de Figueiredo. Direito penal..., cit., pp. 161-162 (destaques originais).

${ }^{526}$ Destaca FERRARI que "Não há a nosso ver, diferença ontológica entre os bens tutelados economicamente pelo âmbito administrativo se comparado com a seara penal. Ambos protegem a ordem econômica e o regular desenvolvimento do mercado, restando claro que dois são os melhores meios preventivos de maior realizabilidade ao desenvolvimento da economia: a informação e a organização administrativa". FERRARI, Eduardo Reale. Legislação penal..., cit., p. 261-262.

${ }^{527}$ Em sentido oposto, D’ÁVILA, Fábio Roberto. Direito penal e direito sancionador. Revista Brasileira de Ciências Criminais, v. 14, n. 60, São Paulo, p. 9 e ss. O autor é também citado por REALE JÚNIOR, que assim resume as idéias do autor: "Em sentido contrário, recentemente, o estudo de Fábio Roberto D' Avila, que propõe uma diferença material. Para o autor o ilícito penal exige a proteção de um bem jurídico-penal, dotado de dignidade penal, de consistência axiológica, a partir da qual se pode concretizar a análise da ofensa. A ofensividade é o principal dado identificador do ilícito penal, como exigência de dano ou perigo ao bem jurídico-penal, que o distingue das infrações de simples desobediência, pois se requer possibilidade não insignificante de dano ao bem jurídico". REALE JÚNIOR, Miguel. Ilícito administrativo..., cit., p. 94 (itálicos originais). Costa também menciona o trabalho do autor gaúcho: COSTA, Helena Regina Lobo da. Proteção penal..., cit., p. 205.

${ }^{528}$ COSTA, Helena Regina Lobo da. Proteção penal..., cit., pp. 201-203.
} 
a qual, não obstante, não se dá de uma maneira arbitrária. Neste sentido, o mesmo ocorre com o ilícito administrativo, que é criado, dessarte, normativamente.

A categoria "ilícito", independentemente de suas espécies, consubstancia-se em algo normativo, motivo pelo qual as teorias ontológicas possuem um pressuposto fundamental equivocado, segundo a autora brasileira citada:

(...) as teorias qualitativas que se baseiam em supostas diferenças ontológicas falham por adotarem um ponto de partida equivocado. Também pecam por acabar aceitando a existência de um núcleo duro de condutas que precisariam ser sancionadas por meio do direito penal, estabelecendo, portanto, espaços de criminalização obrigatória, o que não se coaduna com um direito penal fragmentário e subsidiário ${ }^{530}$.

Por esta motivação, a autora, seguindo posicionamento similar a REALE JÚNIOR $^{531}$, defende que as diferenças hão de ser investigadas normativamente ${ }^{532}$, o que, por certo, possui o condão de justificar a melhor opção para cada situação concreta. Em outras palavras, “(...) a escolha pela qualificação de uma conduta como ilícito penal ou administrativo não é senão de política legislativa, tendo em vista, primordialmente, a busca de maior eficácia social" ${ }^{, 533}$.

No mesmo diapasão, refletindo especificamente acerca da seara econômica, EDUARDO REALE FERRARI observa que importa muito mais a efetividade da sanção, com vistas ao bom andamento da economia, do que propriamente a modalidade dessa resposta punitiva ${ }^{534}$.

\footnotetext{
${ }^{529}$ Segundo o autor espanhol: “(...) O ilícito não existe na realidade, sendo criado pela norma, de modo que sem norma não pode haver ilícito. Sem norma que estabeleça uma proibição, não se pode violar proibição alguma (...)". NIETO GARCÍA, Alejandro. Derecho administrativo..., cit., p. 154 (tradução livre).

${ }_{530}$ COSTA, Helena Regina Lobo da. Proteção penal..., cit., pp. 202-203.

${ }^{531}$ REALE JÚNIOR, Miguel. Ilícito administrativo..., cit., p. 95.

532 COSTA, Helena Regina Lobo da. Proteção penal..., cit., p. 203. No mesmo sentido, BECHARA, Ana Elisa Liberatore Silva. Da teoria..., cit., p. 253.

${ }^{533}$ REALE JÚNIOR, Miguel. Ilícito administrativo..., cit., p. 95.

${ }^{534}$ FERRARI, Eduardo Reale. Legislação penal..., cit., p. 262.
} 


\subsubsection{Razões alegadas para a utilização do Direito Administrativo Sancionador}

Verificada a ausência de uma distinção ontológica entre as espécies de ilícitos, posicionamento adotado na presente investigação, cumpre verificar, então, as possíveis justificativas, ou razões, pelas quais o legislador pode adotar validamente um ou outro caminho. Ou seja, se a construção em comento é normativa, há de se constatar quais os requisitos necessários para um regramento cerceador legítimo ${ }^{535}$.

Em busca da constatação da idoneidade de instrumento ${ }^{536}$ a ser utilizado, $\operatorname{COSTA}^{537}$, citando HASSEMER ${ }^{538}$, refere-se que, para se concluir por uma criminalização válida, é preciso empregar o critério fundamental de aferição da dignidade penal, composto pelos elementos justiça e adequação aos fins. Justiça, empregado na hipótese com o sentido de verificação na específica vedação pretendida de lesão ou perigo de lesão a um bem jurídico penal, mediante o respeito aos princípios essenciais do Direito Penal ${ }^{539}$. E, adequação aos fins, entendida como viabilidade do meio empregado (criminalização) para o alcance do fim (tutela do bem jurídico penal) ${ }^{540}$.

Por conta de sua maior gravidade, a autora nota que o ilícito penal exige mais requisitos para sua configuração que o ilícito administrativo. Assim é que propõe como requisitos de um critério diferenciador que possa caracterizar legitimamente uma proteção jurídico-criminal a conduta ser essencial para o livre desenvolvimento humano em

\footnotetext{
535 Segundo REALE JÚNIOR: "Normativamente, o ilícito penal exige o atendimento de uma série de requisitos para se perfazer, enquanto o ilícito administrativo é limitado por alguns critérios diversos dos adotados no direito penal. Os sistemas também se diferenciam no que se refere à técnica de atuação". REALE JÚNIOR, Miguel. Ilícito administrativo..., cit., p. 95.

${ }^{536}$ REALE JÚNIOR, Miguel. Ilícito administrativo..., cit., p. 95.

${ }^{537}$ COSTA, Helena Regina Lobo da. Proteção penal..., cit., p. 203.

538 "Winfried HASSEMER alude a uma diferença qualitativa entre ilícito penal e ilícito administrativo, representada não por distintos bens jurídicos, mas, sim, pela distinta técnica de sua tutela, entendendo que o direito penal administrativo e o direito penal legitimam-se a partir da prevenção de perigos ou lesões a bens jurídicos. Porém, o direito penal administrativo realiza a tutela dos mesmos bens jurídicos de modo qualitativamente diverso do direito penal, recorrendo a sanções e estabelecendo um procedimento distinto. Aquele atua tipicamente como forma de tutela antecipada dos bens jurídicos clássicos, reprimindo condutas não de imediato voltadas a lesionar ou colocar em perigo o bem jurídico, senão situações de perigo estandartizadas”. BECHARA, Ana Elisa Liberatore Silva. Da teoria..., cit., p. 252.

${ }^{539}$ COSTA, Helena Regina Lobo da. Proteção penal..., cit., p. 203.

${ }^{540}$ COSTA, Helena Regina Lobo da. Proteção penal..., cit., p. 203.
} 
sociedade, a previsão constitucional de tutela do interesse e a constatação de adequação quanto à sua funcionalidade técnica ${ }^{541}$.

Dessa forma, em termos penais, frise-se, o intérprete encontra como balizas essenciais para suas conclusões a verificação, caso a caso, da presença concomitante de um bem jurídico penal, do respeito aos princípios fundamentais do Direito Penal, assim como da eficiência na utilização do sistema jurídico-criminal para a pretendida vedação de conduta.

Assim é que, por exemplo, ainda que se depare com um bem jurídico de natureza penal, com respeito às regras-mestras deste ramo jurídico, mas, ainda dessa maneira, constatada uma criminalização ineficiente, ter-se-á uma norma justa, porém inadequada, que deve ser afastada do ordenamento, por carecer de sentido. O oposto, isto é, uma norma eficiente mas injusta, vilipendia completamente as noções primárias que se têm do Estado de Direito. Nas precisas palavras de COSTA:

Justiça e adequação são dois elementos que se relacionam de forma dinâmica. A criminalização eficiente, porém injusta, transforma o direito em terror, viola os direitos fundamentais da pessoa e acaba por esgarçar, a longo prazo, a própria força e credibilidade do direito penal. Dessa forma, ela não consegue alcançar a finalidade da pena e se mostra, ao final, ineficiente. Já a pena justa, porém ineficiente corrói a confiança na aplicação das normas, além de gerar desigualdade, pois a pena aplicada ineficientemente aumenta ainda mais a seletividade do direito penal, produzindo déficits de execução. A violação do princípio da igualdade, afinal, acaba por perverter a própria justiça da incriminação ${ }^{542}$.

O Direito Administrativo Sancionador poderá então tutelar um bem jurídico de natureza penal caso demonstre deter mais rendimento para tanto. Não há nenhum prejuízo à cidadania nesta medida. Por outro lado, o tipo penal carecedor de bem jurídico digno de tal tutela, com mera função de conformação de direitos, limitando-os ou restringindo-os, revela-se ilegítimo ${ }^{543}$.

\footnotetext{
${ }^{541}$ COSTA, Helena Regina Lobo da. Proteção penal..., cit., p. 203 e ss.

${ }^{542}$ COSTA, Helena Regina Lobo da. Proteção penal..., cit., p. 204.

${ }^{543}$ Cf. referido acima, item "1.2.1.1".
} 
Referidos parâmetros deverão, portanto, nortear o intérprete da norma penal econômica. Todavia, antes da consolidação desta reflexão, mister se faz descrever as significativas propostas de aperfeiçoamento do Direito Administrativo Sancionador, insculpidas na doutrina nacional a partir do pensamento de REALE JÚNIOR. Uma vez adotadas tais idéias, em nome de maior legitimidade e funcionalidade técnica, certamente facilita-se a eventual defesa de tutela da ordem econômica pelo ramo administrativo.

\subsubsection{Propostas para o aperfeiçoamento do Direito Administrativo Sancionador}

Como referido, os estudos doutrinários em foco não apenas defendem significativa descriminalização de condutas atentatórias à ordem econômica ou ao meio ambiente, por exemplo, mas também se preocupam em oferecer um ideário viável de tutela jurídica a interesses sociais de largo relevo - os quais, frise-se, podem até possuir dignidade penal, mas muitas vezes devem ser tratados por outro ramo jurídico, em face, dentre outros motivos, de uma melhor eficiência. Neste sentido, os autores nacionais citados formulam proposições de lege ferenda com vistas à construção de uma disciplina válida e eficaz num Estado Democrático de Direito.

Justificando a criação da citada proposta de uma Parte Geral do Direito Administrativo Sancionador, em busca de maior rendimento na tutela dos interesses por este ramo disciplinados, e, fundamentalmente, com vistas a afastar-se de qualquer possibilidade de consagração do arbítrio estatal, escreve REALE JÚNIOR:

Ao nosso ver deve haver uma Parte Geral nas leis tipificadoras das infrações administrativo-penais, que contenha os princípios garantistas próprios do Direito Penal aplicáveis às infrações administrativo-penais, bem como os princípios ordenadores do conjunto normativo. Estes permitem, de um lado, dotar de eficácia as normas infracionais, ampliando o âmbito de incidência - o que ocorre, como veremos, na hipótese de responsabilidade solidária, na forma comissiva por omissão - e, de outro, limitar a sua incidência, o que sucede na admissão do erro de tipo ou da extinção da punibilidade ${ }^{544}$.

544 REALE JÚNIOR, Miguel. Despenalização no..., cit., p. 125 (itálicos originais). Analisando especificamente as infrações ao meio ambiente, COSTA também defende a construção de uma Parte Geral do Direito Administrativo Sancionador: “(...) não se pode prescindir, no direito administrativo, de regras gerais, organizadas em uma Parte Geral, que defina, em consonância com os preceitos constitucionais, os princípios fundamentais, os pressupostos para a configuração da infração, o modo como se dará a imputação de responsabilidade, as sanções aplicáveis e as normas e garantis processuais do ilícito ambiental administrativo. 
A seguir, o autor brasileiro, ressaltando que não pretende esgotar o temário, sistematiza sete sugestões ${ }^{545}$ para o delineamento de sua proposta de referida novel Parte Geral, quais sejam: a) a adoção do princípio da legalidade; b) a flexibilização da aferição do elemento subjetivo na hipótese, com uma presunção de dolo; c) o estabelecimento da solidariedade entre a empresa e seu dirigente na imputação da prática de infração à ordem econômica; d) a fixação de normas relativas às causas dirimentes escoradas na inexigibilidade de outra conduta; e) a previsão do erro de tipo e de força maior, a excluir a sanção; f) o regramento preciso da individualização da sanção; g) a contemplação de causas de extinção da punibilidade e prescrição sancionatória ${ }^{546}$.

Ainda, merecem menção as observações, destacadas por COSTA e FERRARI, no sentido de haver necessidade de oferecimento de um sistema processual adequado $^{547}$ ao Direito Administrativo Sancionador, ressaltando-se garantias aos órgãos envolvidos.

Mister se faz, assim, observar cada uma das propostas referidas.

\subsubsection{Adoção do princípio da legalidade}

O tema ocupa posição central na delimitação do ilícito administrativo ${ }^{548}$, consoante afirma COSTA, estando bastante assentado no Direito Administrativo ${ }^{549}$.

Esses parâmetros gerais deverão ser aplicados para todas as infrações administrativas na esfera ambiental". COSTA, Helena Regina Lobo da. Proteção penal..., cit., pp. 216-217.

545 Referidos pontos são também cuidados por COSTA. Cf. COSTA, Helena Regina Lobo da. Proteção penal..., cit., p. 220 e ss.

${ }^{546}$ REALE JÚNIOR, Miguel. Despenalização no..., cit., pp. 126-128.

${ }^{547}$ A respeito do tema, v. ainda, OSÓRIO, Fábio Medina. Direito administrativo..., cit., p. 383 e ss.

${ }^{548} \mathrm{O}$ assunto possui destaque na doutrina espanhola. GÓMEZ TOMILLO, e.g., em alentada análise, resumidamente entende que seus consectários são: a obrigatoriedade de reserva de lei, o respeito ao princípio da taxatividade, a proibição de analogia in malam partem, a irretroatividade da norma desfavorável e a retroatividade da favorável e o respeito ao princípio do non bis in idem material. GÓMEZ TOMILLO, Manuel. Derecho administrativo..., cit., pp. 99-227. Sobre o tema, cf. também exemplificativamente: PEREÑA PINEDO, Ignacio (Coordinación). Manual de..., cit., pp. 123-171; MESEGUER YEBRA, Joaquín. La tipicidad de las infracciones en el procedimiento administrativo sancionador. Barcelona: Bosch, 2001, pp. 15-20.

${ }^{549}$ COSTA, Helena Regina Lobo da. Proteção penal..., cit., p. 219. 
Quanto a este aspecto, REALE JÚNIOR entende que deve haver a proibição da analogia in malam partem, além da previsão da retroatividade da lei mais benigna, da consagração de uma interpretação estrita ${ }^{550}$, respeitando-se a verificação da tipicidade da conduta, atendendo-se a técnica de construção taxativa, que, por conseguinte, evite a utilização de expressões genéricas, abertas ou o reenvio a conceitos extra-jurídicos ${ }^{551}$. Também como consequiência da adoção do princípio da legalidade, as sanções cominadas devem ser certas e prévias ${ }^{552}$.

O respeito ao princípio da legalidade pelo ramo administrativo sancionador ou seja, do atendimento à regra de que o cerceamento estatal de condutas na seara administrativa se dê por meio de lei em sentido formal, anterior e certa ${ }^{553}$ - consubstanciase em uma basilar garantia de limitação do poder do Estado em face da liberdade dos cidadãos, essencial no Direito Penal, no Direito Tributário ${ }^{554}$ e no Direito Administrativo. Desse modo, ainda que inegavelmente haja maior flexibilidade na repressão administrativa do que na penal ${ }^{555}$, forçoso estabelecer-se limites formais e materiais ${ }^{556}$ capazes de rechaçar a arbitrariedade.

\footnotetext{
${ }^{550}$ Aspecto curial, vez que norma restritiva interpreta-se restritivamente.

${ }^{551}$ REALE JÚNIOR, Miguel. Despenalização no..., cit., p. 126.

${ }_{552}^{5}$ REALE JÚNIOR, Miguel. Despenalização no..., cit., p. 126.

${ }_{553}$ COSTA, Helena Regina Lobo da. Proteção penal..., cit., p. 220.

${ }_{554}^{554}$ COSTA, Helena Regina Lobo da. Proteção penal..., cit., p. 223.

${ }^{555}$ Demonstrativo disto encontra-se na competência legislativa concorrente entre União, Estados e Distrito Federal para criação de ilícitos administrativos, fixada pela Lei Maior, assim como na possível necessidade de complementação de lei por regulamentos administrativos, o que, se por um lado também deve ser evitado, por outro, em muitas situações afigura-se como algo inevitável e, de todo modo, mais tolerável do que na seara penal. Cf. COSTA, Helena Regina Lobo da. Proteção penal..., cit., p. 221 e ss.

556 "É importante introduzir ao ilícito administrativo considerações de ordem material. No direito administrativo, são admitidos ilícitos que não lesionem ou coloquem em perigo bens jurídico-penais. Isso não significa, entretanto, que o ilícito administrativo deva ser desprovido de conteúdo material. No caso ambiental, o critério material delimitador deverá ser o interesse coletivo concretizado na proteção do meio ambiente. Trata-se de fórmula aberta, mas que certamente poderá minimizar muitas arbitrariedades". COSTA, Helena Regina Lobo da. Proteção penal..., cit., p. 223. De modo similar, sobre o específico objeto de investigação deste trabalho, pode-se adotar como critério material delimitador da infração econômica o interesse coletivo concretizado na proteção da ordem econômica.
} 


\subsubsection{A flexibilização da aferição do elemento subjetivo na hipótese, com uma presunção de dolo}

A necessidade de flexibilização da constatação do elemento subjetivo nos ilícitos administrativos é a solução, possível no âmbito do Direito Administrativo Sancionador, para um enorme problema de dificuldade estrutural do Direito Penal Econômico, qual seja, o da "prova de efetiva participação dos administradores com consciência e vontade na prática do fato" ${ }^{, 557}$.

Dessa maneira, um dos aspectos cruciais para falta de efetividade da tutela penal da ordem econômica, possível ensejador de impunidade, pode ser equacionado pelo ramo administrativo sancionador, sendo, consoante REALE JÚNIOR, um dado diferenciador primordial entre o ilícito penal e o administrativo ${ }^{558}$. Mas o autor vai mais além na busca pela eficiência do sistema administrativo, observando ser possível admitir-se uma presunção relativa do dolo ${ }^{559}$.

\subsubsection{O estabelecimento da solidariedade entre a empresa e seu dirigente na imputação da prática de infração à ordem econômica}

A fixação na Parte Geral do Direito Administrativo Sancionador da solidariedade entre a empresa e seu dirigente quanto aos atos abusivos tem por objetivo evitar a impunidade no caso concreto mediante a estipulação de um dever de agir como garante por parte deste:

(...) Essa solidariedade há de ser estendida tendo por base estipulação, a constar da Parte Geral, de que existe, por parte do diretor ou gerente, um dever de agir como garante no impedimento de ações de abuso do poder econômico, limitado esse dever pelo poder de agir dentro do âmbito decisório da empresa. Assim sendo, seja na forma comissiva, como comissiva por omissão, estabelece-se a solidariedade entre a empresa e seu dirigente na imputação da prática de infração à ordem econômica ${ }^{560}$.

\footnotetext{
${ }^{557}$ REALE JÚNIOR, Miguel. Despenalização no..., cit., p. 127.

${ }^{558}$ REALE JÚNIOR, Miguel. Despenalização no..., cit., p. 127.

${ }^{559}$ Proposta não referida, e.g., por COSTA, para quem a responsabilidade da pessoa física é sempre subjetiva e, por sua vez, quanto à pessoa jurídica, há de sempre se aferir um mínimo de culpa. COSTA, Helena Regina Lobo da. Proteção penal..., cit., p. 224.

${ }^{560}$ REALE JÚNIOR, Miguel. Despenalização no..., cit., p. 128.
} 


\subsubsection{A fixação de normas relativas às causas dirimentes escoradas na inexigibilidade de outra conduta}

Se os dois itens anteriores consubstanciam-se em elementos de maior flexibilização relativamente à sistemática penal com vistas à maior efetivação punitiva na seara administrativa, o presente, como os próximos, resgata a idéia, tal qual do princípio da legalidade referido acima, de consolidação de mais significativa certeza jurídica, em prol da segurança do Direito Administrativo Sancionador. Percebe-se, assim, que REALE JÚNIOR procura delinear mais eficácia ao regramento, mas sem perder de vista jamais a vedação ao arbítrio estatal, fonte de injustiça.

Nesse sentido, o autor propõe o estabelecimento de normas relativas às dirimentes escoradas na não exigibilidade de outra conduta, como a "coação irresistível e o estado de necessidade, situações que se podem apresentar possíveis, como na hipótese de ações concertadas de fixação uniforme de preços, sob pressão dos demais concorrentes" ${ }^{\text {}}$.

\subsubsection{A previsão do erro de tipo e de força maior, a excluir a sanção}

Outro aspecto importante, plasmado a partir da dogmática penal, é a disciplina do erro na Parte Geral do Direito Administrativo Sancionador. Como nota COSTA, citando LESMES SERRANO, não há que se punir a pessoa física a qual não deteve uma possibilidade plausível de conhecer seus deveres ${ }^{562}$. Do mesmo modo que nota a autora no que concerne à complexidade normativa ambiental dever possibilitar a aplicação da disciplina do erro no ramo administrativo ${ }^{563}$, também assim há de se proceder, por razoabilidade, no campo econômico, no qual a normatização mostra-se ainda mais vasta e intrincada.

\footnotetext{
${ }^{561}$ REALE JÚNIOR, Miguel. Despenalização no..., cit., p. 128. No mesmo sentido, COSTA, que ainda observa que "Nesse ponto, interessante mencionar que o sistema alemão de contra-ordenações também adota a idéia de censurabilidade, mas prevê que, em alguns casos, verificada a prática por pessoa jurídica de conduta típica e antijurídica, mas não censurável, podem ser aplicadas algumas medidas de natureza não sancionatória”. COSTA, Helena Regina Lobo da. Proteção penal..., cit., p. 226.

${ }^{562}$ COSTA, Helena Regina Lobo da. Proteção penal..., cit., p. 225.

${ }^{563}$ COSTA, Helena Regina Lobo da. Proteção penal..., cit., p. 225.
} 
Ilustrando a possibilidade de ocorrência de força maior numa infração econômica, a justificar a exclusão da sanção, escreve REALE JÚNIOR:

(...) se, por ventura, o fato ocorrer em razão de força maior, no caso, por exemplo, de recusa de venda de bens dentro das condições de pagamento normais (art. 21, XIII) tendo em vista a falta de energia que impeça o carregamento da mercadoria, nem por isso se estabelece uma responsabilidade objetiva, pois o ato há de ser praticado com o objetivo de limitar a concorrência $^{564}$.

\subsubsection{O regramento preciso da individualização da sanção}

A necessidade de estabelecimento de claro regramento acerca da individualização da resposta punitiva é ponto essencial a fim de se evitar a consagração de injustiças na seara administrativo-sancionadora, quer pela possibilidade de aferição prática de impunidades ou de exageros na sanção fixada. Por isso, o estabelecimento de circunstâncias agravantes ou atenuantes ${ }^{565}$, causas de aumento ou diminuição da medida punitiva, regras para hipóteses de concurso material, formal ou continuidade de infrações ${ }^{566}$, dentre outras, trazem segurança jurídica e possuem o condão de particularizar de forma apropriada a sanção em cada caso concreto ${ }^{567}$.

Como exemplo de norma inadequada, a ser evitada, REALE JÚNIOR referese ao artigo 27 da Lei 8.884/94 (Lei Antitruste) ${ }^{568}$ :

Art. 27. Na aplicação das penas estabelecidas nesta lei serão levados em consideração:

I - a gravidade da infração;

II - a boa-fé do infrator;

III - a vantagem auferida ou pretendida pelo infrator;

IV - a consumação ou não da infração;

\footnotetext{
${ }^{564}$ REALE JÚNIOR, Miguel. Ilícito administrativo..., cit., p. 99.

${ }^{565}$ REALE JÚNIOR, Miguel. Despenalização no..., cit., p. 128.

${ }^{566}$ Quanto aos três últimos exemplos, vide: OSÓRIO, Fábio Medina. Direito administrativo..., cit., p. 331 e SS.

567 "Se cada ser humano é um indivíduo, cada infrator deve receber um tratamento individualizado, particular, com a possibilidade de conhecer as concretas e específicas razões do ato sancionador, podendo impugná-lo ou aceitá-lo. Essa individualização se aplica às pessoas jurídicas, igualmente dotadas de peculiaridades relevantes, na perspectiva de assegurar sanções proporcionais”. OSÓRIO, Fábio Medina. Direito administrativo..., cit., p. 374.

${ }^{568}$ REALE JÚNIOR, Miguel. Despenalização no..., cit., p. 128.
} 


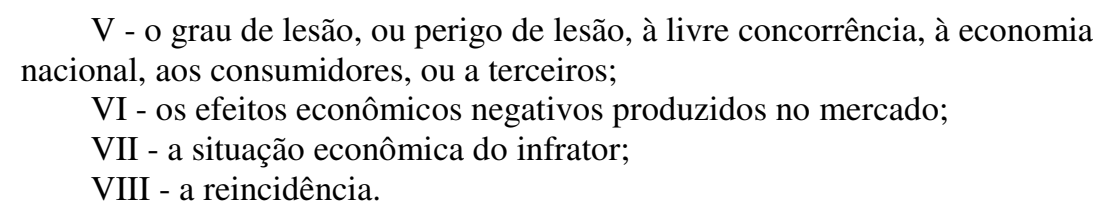

Observe-se que a singeleza da disciplina da aplicação da pena em referido diploma dá margem ao arbítrio do julgador. Os termos legais são por demais genéricos e não há outros artigos no corpo do diploma que tratem do tema, de forma que fica comprometida a mínima noção de segurança jurídica na espécie.

Assim sendo, a precisa delimitação da aplicação das sanções administrativosancionadoras e, antes disso, delas próprias, como afirma $\operatorname{COSTA}^{569}$, constitui ponto também essencial para a plena validade e eficácia da matéria. Nesse aspecto, a autora observa com propriedade a impossibilidade de cominação de pena de prisão ou de prestação de serviços à comunidade ${ }^{570}$.

Além da multa, o artigo 24 da Lei Antitruste traz outros exemplos de possibilidades sancionatórias na seara econômica, algumas muito graves: I - a publicação, em meia página e às expensas do infrator, em jornal indicado na decisão, de extrato da decisão condenatória, por dois dias seguidos, de uma a três semanas consecutivas; II - a proibição de contratar com instituições financeiras oficiais e participar de licitação tendo por objeto aquisições, alienações, realização de obras e serviços, concessão de serviços públicos, junto à Administração Pública Federal, Estadual, Municipal e do Distrito Federal, bem como entidades da administração indireta, por prazo não inferior a cinco anos; III - a inscrição do infrator no Cadastro Nacional de Defesa do Consumidor; IV - a recomendação aos órgãos públicos competentes para que: a) seja concedida licença compulsória de patentes de titularidade do infrator; b) não seja concedido ao infrator parcelamento de tributos federais por ele devidos ou para que sejam cancelados, no todo ou em parte, incentivos fiscais ou subsídios públicos; V - a cisão de sociedade, transferência de controle societário, venda de ativos, cessação parcial de atividade, ou qualquer outro ato ou providência necessários para a eliminação dos efeitos nocivos à ordem econômica.

\footnotetext{
${ }^{569}$ COSTA, Helena Regina Lobo da. Proteção penal..., cit., p. 228 e ss.

${ }^{570}$ COSTA, Helena Regina Lobo da. Proteção penal..., cit., p. 229.
} 
Portanto, o regramento preciso quanto ao aspecto sancionatório da infração administrativa é elementar para a consecução de um sistema de controle não-penal de acordo com os princípios maiores de Estado Democrático de Direito.

\title{
4.5.4.7. A contemplação de causas de extinção da punibilidade e prescrição sancionatória
}

Também sob a perspectiva da segurança jurídica ${ }^{571}$, forçoso serem contempladas as causas de extinção da punibilidade e a prescrição sancionatória na disciplina geral administrativo-sancionadora ${ }^{572}$.

As previsões de consequiências para morte do agente, extinção da pessoa jurídica $^{573}$, pagamento de indenizações a consumidores ou a troca mais vantajosa para estes de produtos defeituosos, dentre outras possibilidades de causas extintivas da punibilidade administrativa no regramento das infrações econômicas, hão de ser insculpidas com vistas à justiça das soluções concretas.

Ainda, especificamente quanto à prescrição como causa de extinção da punibilidade, observa com adequação OSÓRIO:

\begin{abstract}
A justificação constitucional para o instituto da prescrição é, sem dúvida, o princípio da segurança jurídica. Ninguém pode ficar à mercê de ações judiciais ou administrativas por tempo e prazos indefinidos ou, o que é pior, perpétuos. Trata-se de uma garantia individual, porém com intensa transcendência social. As relações sociais necessitam de segurança e o Direito busca, em um de seus fins, assegurar estabilidade na vida de relações. Não é possível uma ausência de limites para que alguém acione o outro por supostos danos materiais ao erário, em busca da imposição de censura ${ }^{574}$.
\end{abstract}

\footnotetext{
${ }^{571}$ No mesmo sentido quanto à prescrição: OSÓRIO, Fábio Medina. Direito administrativo..., cit., pp. 426427.

572 REALE JÚNIOR, Miguel. Despenalização no..., cit., p. 128. Também COSTA menciona a necessidade de estabelecimento de prazo prescricional: COSTA, Helena Regina Lobo da. Proteção penal..., cit., p. 226.

573 Sobre as hipóteses de morte do agente e de dissolução da pessoa jurídica no caso das infrações administrativas, cf. GÓMEZ TOMILLO, Manuel. Derecho administrativo..., cit., p. 563 e ss.

${ }^{574}$ OSÓRIO, Fábio Medina. Direito administrativo..., cit., p. 427.
} 


\subsubsection{Erigimento de um sistema processual adequado, com independência orgânica}

A intervenção administrativo-sancionadora consubstancia-se em séria interferência na esfera de liberdade dos indivíduos, muitas vezes com possibilidade prática de revelar-se até mais gravosa do que uma resposta penal, como afirmado. Ademais, a Administração Pública não pode ser considerada como elemento neutro na relação processual com o argüido, vez que possui interesse direto no resultado do processo ${ }^{575}$.

Assim é que a construção do Direito Administrativo Sancionador há de se pautar por critérios de aplicabilidade que tenham por escopo a neutralização desse desequilíbrio, para a consagração de uma aplicação justa. Isto significa que, num Estado Democrático de Direito, deve ser erigido um sistema processual administrativo adequado, pautado pela proteção da parte desfavorecida e escorreita aplicação da lei.

Em outras palavras, este objetivo somente há de ser alcançado mediante um esquema técnico-jurídico de garantias ao indivíduo administrativamente processado, bem como de máxima isenção de julgamento. Este é o sentido de idéias desenvolvidas em nossa doutrina pelos autores em foco.

Consoante o ordenamento jurídico delineado por nossa Carta Política, em síntese, menciona-se a necessidade de respeito aos princípios do devido processo legal, do contraditório e da ampla defesa, da publicidade, da motivação e da recorribilidade ${ }^{576}$. Ainda, consoante o princípio da presunção de inocência, destaca-se que o ônus probatório é da Administração, vedadas provas ilegítimas, como interceptações telefônicas ou quebras de sigilos sem autorização judicial, sendo facultado ao imputado o direito de produzir provas, como perícias e apresentação de declarações escritas ${ }^{577}$.

\footnotetext{
${ }^{575}$ COSTA, Helena Regina Lobo da. Proteção penal..., cit., p. 231.

${ }^{576}$ COSTA, Helena Regina Lobo da. Proteção penal..., cit., p. 232 e ss.; OSÓRIO, Fábio Medina. Direito administrativo..., cit., p. 383 e ss.

577 COSTA, Helena Regina Lobo da. Proteção penal..., cit., p. 233 e ss.; OSÓRIO, Fábio Medina. Direito administrativo..., cit., p. 383 e ss.
} 
Assevera-se também que a Administração pode se utilizar de medidas cautelares, as quais, por sua vez, podem ser revistas judicialmente ${ }^{578}$. Aliás, quanto a este aspecto, COSTA ressalta a hipótese constitucional de possibilidade de socorro ao Poder Judiciário, relativamente às medidas cautelares administrativas ou às decisões finais ${ }^{579}$.

Por fim, um importante aspecto a ser referenciado é a indispensabilidade de reestruturação dos órgãos administrativos, quer de apuração, quer de julgamento, com vistas à sua imparcialidade e independência.

Neste diapasão, COSTA defende que o órgão o qual investiga a infração administrativa há de ser diverso daquele que o julga ${ }^{580}$. FERRARI, por sua vez, sensível à realidade nacional, ademais, destaca a importância da estabilidade de vencimentos e do cargo e da estruturação de pessoal do órgão, dentre outros pontos essenciais:

Conferindo aos integrantes do Órgão Julgador Administrativo as garantias de independência e estabilidade de vencimentos, inclusive com enunciação de período de quarentena, seus membros devem ser compostos por pessoas independentes dos Poderes Legislativo e Executivo, com prerrogativas próprias do Poder Judiciário, com mandatos que assegurem o mínimo de estabilidade para o julgamento especializado e imparcial, pregando o Direito Administrativo Penal por um investimento não apenas estrutural mas, especificamente, pessoal, criando uma estrutura administrativo e econômica no quadro dos auxiliares dos julgadores, especializando-os no âmbito da seara administrativa-econômica, a representar uma tentativa de fortalecer a estrutura administrativa, sem a necessária burocracia hoje existente no Poder Judiciário, permitindo-se que em única instância recorra-se ao Poder Judiciário, nos moldes da Lei de Arbitragem $^{581}$.

Ante o exposto, nota-se que as sugestões não exaustivas dos autores brasileiros citados ostentam, por seus próprios delineamentos, ampla viabilidade na consecução de uma sistemática administrativa aperfeiçoada, não desvirtuada em quaisquer de seus objetivos, para a eficaz tutela de caros interesses para a realidade econômica. Não representam qualquer quebra sistêmica na esfera do Direito Administrativo, respeitando os

\footnotetext{
578 COSTA, Helena Regina Lobo da. Proteção penal..., cit., p. 235; OSÓRIO, Fábio Medina. Direito administrativo..., cit., p. 407-408.

${ }^{579}$ COSTA, Helena Regina Lobo da. Proteção penal..., cit., p. 235.

${ }^{580}$ COSTA, Helena Regina Lobo da. Proteção penal..., cit., p. 232.

${ }^{581}$ FERRARI, Eduardo Reale. Legislação penal..., cit., p. 294.
} 
contornos de um sistema político de contornos liberais. Por tais razões, hão de ser seriamente consideradas relativamente ao ordenamento brasileiro. 


\section{O DIREITO PENAL E AS INFRAÇÕES ECONÔMICAS}

SUMÁRIO: 5.1. Introdução; 5.2. Os discursos de criminalização difusa; 5.3. A tutela da ordem econômica - finalidade e eficiência: deslegitimação do Direito Penal; 5.4. As opções jurídicas como lege ferenda.

\subsection{Introdução}

O presente capítulo, de característica conclusiva, tem por escopo firmar posicionamento pela legitimidade ou não do Direito Penal Econômico. Para uma tal tomada de posição, há de se sintetizar os discursos de criminalização difusa, anteriormente apontados, os quais buscam, pelos mais diversos argumentos, respaldar a tutela penal econômica, apontando-se a finalidade e a eficiência do Direito Penal na seara econômica, além da estruturação técnica concreta deste ramo jurídico-criminal. Para além dos fins do Direito Penal, há de se analisar a compatibilidade estrutural da tipificação penal econômica.

Assim, serão explicitadas as soluções mais adequadas com vistas ao equacionamento dos comportamentos econômicos indesejados pela sociedade, diante de um contexto de Estado Democrático de Direito, ou seja, apontar-se-á a regulação jurídica mais adequada à delinquiência econômica.

Neste sentido, as características de conformação de direitos, de flexibilidade de tutela e de viés preventivo, está, como se verá, a apontar o Direito Administrativo como o ramo jurídico mais adequado a cuidar da maior parte das infrações econômicas. Mas esse campo do Direito há de ser repensado, fortalecendo-se seu viés sancionador, sem se perder de vista os delineamentos de um sistema democrático, forçosamente garantista. Portanto, há de se frisar as propostas de lege ferenda tidas como mais pertinentes à hipótese. Esta a pretendida contribuição original da presente tese à ciência jurídica brasileira. 


\subsection{Os discursos de criminalização difusa}

Entende-se por discursos de criminalização difusa os pensamentos doutrinários que visam referendar a tutela penal dos novos interesses postos pela sociedade do risco. Partindo do pressuposto de que "estes novos riscos quase sempre são decorrentes de, ao menos em tese, decisões humanas, chegou-se à conclusão de que talvez fosse o Direito Penal eficaz para sua tutela", erigindo-se um chamado "Direito Penal da Sociedade de Risco" ${ }^{582}$. Neste sentido, parte da doutrina procura justificar, ou entender por legítimo, o expansionismo jurídico-penal aferível na prática pela constatação da tônica legislativa dos mais diversos países ao redor do mundo nas últimas décadas.

Tendo em vista esse entendimento de que múltiplas problemáticas hodiernas advém de decisões humanas, consoante o pensamento de BECK, busca-se estruturar uma sistemática jurídica voltada à prevenção e controle das fontes de perigo ${ }^{583}$. No que diz respeito ao preciso tema da presente investigação, nesta linha de raciocínio, tomar-se-ia por base que significativas decisões de consectários difusos são levadas a efeito no âmbito empresarial, daí porque sobrelevaria em importância o Direito Penal na seara econômica, sendo justificável o alargamento de seus horizontes sobre este específico campo.

Ao longo deste trabalho científico foram referenciados diversos entendimentos os quais podem ser identificados, por aspectos interligados, ou ainda que por bastante diversos, consoante um discurso de criminalização difusa. Pelos mais diversificados argumentos, o que todos possuem em comum é a compreensão de que o Direito Penal, em maior ou menor medida, deve possuir uma cota de participação face aos desafios pós-industriais, isto é, deve tutelar interesses típicos da sociedade do risco.

Cumpre, então, neste passo, referenciá-los, num panorama geral, tendo em vista que os ideários da Escola de Frankfurt, do Direito de Intervenção e do Direito Administrativo Sancionador, estudados no capítulo anterior, mostram-se como possíveis alternativas teóricas a eles. Embora a construção do Direito Penal de duas velocidades

${ }^{582}$ SILVEIRA, Renato de Mello Jorge. Direito penal econômico..., cit., p. 97.
${ }^{583}$ SILVEIRA, Renato de Mello Jorge. Direito penal econômico..., cit., p. 97. 
também se revele em grande medida como uma alternativa a esse discurso da criminalização difusa, consoante afirmado, finda por se inserir na mesma categoria, eis que reafirma a resposta dentro do Direito Penal. Ou seja, muito embora com delineamento mitigado, a teoria de SILVA SÁNCHEZ é uma proposta abrangida num ideário expansionista jurídico-criminal, segundo entendemos.

Primeiramente, de forma ainda que genérica, observa-se em parte significativa da doutrina penal, em maior ou menor grau, uma valorização do aspecto político criminal na construção do Direito Penal, o que se mostra como algo bastante sensível num contexto de sociedade do risco e culmina por influenciar pensamentos tão diversos de autores como, dentre inúmeros outros, num contexto europeu, ROXIN, JAKOBS, SCHÜNEMANN, SILVA SÁNCHEZ ou DIAS.

Em outras palavras, isto quer dizer que, a partir do paradigma da sociedade do risco, nota-se uma relevante tendência de orientação dos mais diversos discursos dogmático-penais voltada à realidade dos problemas sociais, presentes ou futuros ${ }^{584}$. Pressupostos político-criminais são assim tidos como relevantes, ou mesmo determinantes, para o delineamento dos contornos do Direito Penal.

Esta precisa vinculação político-criminal na configuração do crime é, v.g., a base do funcionalismo penal de ROXIN, desenvolvido a partir de seu destacado trabalho sobre Política criminal e sistema de Direito Penal, de 1970. Dentre outros, SCHÜNEMANN observa que a ampla renormativização do pensamento sistemático jurídico-penal que vem se impondo na Alemanha desde 1970 está estreitamente ligada ao citado estudo programático de ROXIN ${ }^{585}$.

Nota-se, neste influxo, em parte relevante da doutrina contemporânea, notadamente aquela identificada com o funcionalismo penal, de mitigação ou mesmo

\footnotetext{
${ }^{584}$ MACHADO, Marta Rodriguez de Assis. Sociedade do..., cit., p. 92; COELHO, Marina Pinhão. Ensaio sobre a tipicidade penal objetiva em um sistema teleológico-racional. Tese (Doutorado em Direito). Faculdade de Direito da Universidade de São Paulo, São Paulo, 2006, passim.

${ }^{585}$ Cf. SCHÜNEMANN, Bernd. La política criminal y el sistema de derecho penal. Anuario de derecho penal y ciencias penales, Madrid, tomo XLIV, fasc. III, sep.-dic. 1991, p. 703.
} 
negação da idéia de bem jurídico como referente material do Direito Penal ${ }^{586}$. Foi assim

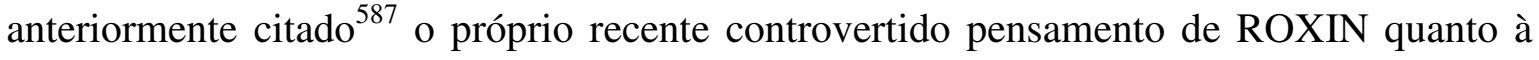
teoria do bem jurídico, admitindo-se o ultrapassar das fronteiras jurídico-criminais para além da proteção de bens jurídicos, em nome da defesa de interesses etéreos típicos de nossa geração, os quais não se coadunariam de modo convincente com o ideário do bem jurídico.

Também está conforme um ideal de abandono da teoria do bem jurídico, mas de forma incisiva, o pensamento de $\mathrm{JAKOBS}^{588}$, o qual referenda a antecipação da tutela penal com vistas à prevenção de comportamentos sociais indesejados, como no campo econômico, respaldando-se assim, dentre outros aspectos, a utilização da técnica tipificadora dos delitos de perigo abstrato ${ }^{589}$. Conforme esse posicionamento normativista sistêmico, o escopo do Direito Penal não seria o de mera proteção de bens jurídicos, mas sim o de assegurar a manutenção do sistema normativo, reafirmando a vigência da norma

\footnotetext{
586 “A compreensão do crime como ofensa a bens jurídico-penais, como dano ou perigo a bens dotados de dignidade penal, embora possa soar, para muitos, como trivialidade, evidência, nomeadamente no espaço de discursividade jurídico-penal brasileiro, é, em verdade, um horizonte compreensivo que, para além de historicamente posto em questão, encontra no direito penal contemporâneo um ambiente hostil, de difícil afirmação e continuidade, muito embora, em um aparente paradoxo, também um dos períodos em que mais tem a oferecer. A ampliação do direito penal secundário, com o surgimento de novos espaços, cada vez mais complexos, de intervenção jurídico-penal, tem levado a um progressivo distanciamento do ilícito penal em relação aos vínculos objetivos que implicam o reconhecimento da ofensividade como elemento de garantia. Mas não só. Tem conduzido a um esfumaçamento dos valores tutelados, a uma perda de densidade tal que o bem jurídico passa a movimentar-se em um espaço de total indiferença em relação a meros interesses de política-criminal, incapaz de atender a uma qualquer pretensão de concretização. $\mathrm{O}$ bem jurídico perde seu caráter crítico e a ofensividade, o lugar primeiro na constituição do ilícito. A flexibilidade de teorias subjetivísticas do ilícito, de concepções puramente normativistas ou, ainda, de leituras meramente formais do ilícito penal, hoje tão em voga, torna-se acintosamente sedutora, mas, em contrapartida, cobra um preço em termos de legitimidade, nomeadamente a supressão de elementos objetivos capazes de propiciar substrato material crítico à construção do ilícito-típico. Daí que a insistência em uma compreensão do crime como ofensa a bens jurídicos, naturalmente revisada, tenha, há um tempo, deixado de ser lugar-comum e assuma hoje um espaço central na discussão sobre a legitimidade do direito penal contemporâneo". D'AVILA, Fabio Roberto. O modelo de crime como ofensa ao bem jurídico. Elementos para a legitimação do direito penal secundário. In: D’AVILA, Fabio Roberto \& SOUZA, Paulo Vinicius Sporleder (Coordenadores). Direito penal secundário: estudos sobre crimes econômicos, ambientais, informáticos e outras questões. São Paulo: Revista dos Tribunais; Coimbra: Coimbra Editora, 2006, pp. 71-96.

587 Item 1.2.1.1.

${ }^{588}$ Também tratado no item 1.2.1.1. Cf. JAKOBS, Günther. Tratado de..., cit., p. 61 e ss.

589 JAKOBS, Günther. Tratado de..., cit., p. 79. Sobre o tema, cf. ainda SILVEIRA, Renato de Mello Jorge. Direito penal econômico..., cit., p. 98.
} 
por meio do sancionamento penal a ingerências humanas na criação de riscos indesejados no entorno social ${ }^{590}$. O delito seria, assim, a violação de um dever.

Forçoso observar, nesse ponto, que, ainda que multifacetado, há em comum em todos os posicionamentos tidos como de discursos da criminalização difusa, ou de Direito Penal da Sociedade do Risco, um processo de espiritualização (ou desmaterialização), ou mesmo de verdadeira negação, do conceito tradicional de bem jurídico $^{591}$. O ideal antropocêntrico, particularizado, com referencial individual, voltado ao erigimento de um elemento crítico limitador da gravosa intromissão jurídico-criminal nos direitos fundamentais do cidadão apenas em situações imprescindíveis para harmônica convivência social passa assim a ser abandonado, em nome de um outro modelo, qual seja, de gerenciamento de riscos, isto é, de pretensa segurança social ${ }^{592}$.

Procurando delinear o entendimento de um denominado bem jurídico intermediário espiritualizado, SCHÜNEMANN o compreende como o bem supraindividual de cunho imaterial que desempenha função de representação de bens finais pertencentes a indivíduos, o que ensejaria autonomia e proteção próprias, esta última concebida em termos abstratos ${ }^{593}$. Assim é que o autor não se afasta de uma teoria do bem

\footnotetext{
590 "Numa linha funcionalista sistêmica, pretende-se justificar a expansão penal a partir do denominado fenômeno de erosão das normas sociais, identificado com a redução das expectativas normativas, em razão da adoção de distintos padrões próprios do pluralismo, do multiculturalismo e das diferenças socioeconômicas em geral. Diante de uma sociedade mais complexa e menos confiável do ponto de vista de suas expectativas, demanda-se ao Estado a assunção da proteção das normas que começam a debilitar-se. A finalidade do direito penal reside, segundo esse enfoque, na conservação e reprodução autorreferencial de valores sistêmicos. Tal construção leva, contudo, à supressão da possibilidade de dissenso valorativo, evitando-se, a partir da não correspondência às expectativas institucionalizadas, qualquer análise ou crítica de conteúdo político, o que conduz à depreciação do próprio conceito de democracia”. BECHARA, Ana Elisa Liberatore Silva. Da teoria..., cit., p. 211

${ }^{591}$ SGUBBI, Filippo. El delito..., cit., p. 70; MACHADO, Marta Rodriguez de Assis. Sociedade do risco..., cit., p. 103 e ss.; BECHARA, Ana Elisa Liberatore Silva. Da teoria..., cit., p. 211, 221, passim; SILVEIRA, Renato de Mello Jorge. Direito penal econômico..., cit., p. 150 e ss. Este último autor observa: "A criação de bens jurídicos metaindividuais é, sem dúvida, uma das técnicas político-criminais de antecipação da tutela penal. Com antecedentes na criação e no desenvolvimento alargado de questões como a saúde e o patrimônio, ao depois, passa-se à regra genérica de tipificação de condutas amplas da sociedade de risco. Freqüente é a justificativa de que isso se dá em direta tentativa de criar um bem jurídico supra-individual em órbita exterior ao plano individualizado". SILVEIRA, Renato de Mello Jorge. Direito penal econômico..., cit., p. 151.

${ }^{592}$ Também foi referido o pensamento de ANDREW VON HIRSCH, segundo o qual a justificativa do fenômeno criminalizador deve ir além do conceito de bem jurídico. HIRSCH, Andrew Von. El concepto..., cit., p. 32 e ss.

${ }^{593}$ SILVEIRA, Renato de Mello Jorge. Direito penal econômico..., cit., p. 152; SILVEIRA, Renato de Mello Jorge. A construção do bem jurídico espiritualizado e suas críticas fundamentais. Boletim IBCCRIM, São Paulo, n. 122, janeiro/2003, pp. 14-15; CORCOY BIDASOLO, Mirentxu. Delitos de peligro y protección de
} 
jurídico, hipótese que considera ser um retrocesso ${ }^{594}$, mas efetivamente transmuta seu ideal tradicional de critério crítico, limitador, para o que pode ser entendido como justificativa para o aumento do espectro de incidência penal diante das novéis dificuldades da sociedade pós-moderna. Defendendo a atuação de um Direito Penal globalizado na seara econômica, inclusive, o autor alemão afirma que "quando a economia globalizada já não pode ser controlada pelo Direito estatal, essa situação chama-se anarquia",595.

Em face das dificuldades de constatação de qualquer lesividade por meio de ações típicas individuais nos bens espiritualizados, o que não justificaria, mas afastaria a incidência do Direito Penal nas infrações econômicas, foi também mencionado ${ }^{596}$ o ideário dos espanhóis MARTÍNEZ-BUJÁN PÉREZ e TERRADILLOS BASOCO, que, em busca da legitimação do Direito Penal Econômico, oferta uma teoria que identifica a existência de um bem jurídico mediato e de um outro imediato. Bem mediato seria necessariamente aquele de viés espiritualizado - como ordem econômica -, enquanto que o imediato ostentaria cunho individual ou difuso, relacionado que estaria com o interesse imediatamente protegido, a ser considerado caso a caso ${ }^{597}$.

STRATENWERTH, por sua vez, entendendo ser imprecisa a noção de bem jurídico, tendo em vista a impossibilidade de ser caracterizar um ideal que se coadune com todas as situações de legítima tutela penal, propõe sua substituição pela noção de tutela de relações da vida como tais, ou por si mesmas, o que melhor justificaria interesses universais. Dessa maneira, seria insculpida uma nova dogmática penal, posicionada à defesa antecipada e preventiva de situações de possível perigo para a estabilidade social e

bienes jurídico-penales supraindividuales. Valencia: Tirant lo Blanch, 1999, p. 260; BECHARA, Ana Elisa Liberatore Silva. Da teoria..., cit., p. 233.

${ }^{594}$ SCHÜNEMANN, Bernd. ¡El derecho..., cit., p. 31.

595 SCHÜNEMANN, Bernd. El derecho en el proceso de la globalización económica. In: LAVEAGA, Gerardo et all (Dir.). Orientaciones de la política criminal legislativa. México, D.F.: INACIPE, 2005, p. 4.

${ }^{596}$ Item 1.3.

597 “(...) a concepção ampla aqui propugnada permite estender a noção a delitos que não possuem um bem jurídico supra-individual como objeto imediato de proteção, englobando também delitos que tutelam diretamente um bem jurídico individual de conteúdo econômico, mas com a particularidade de que se orientam à proteção de um bem jurídico mediato supra-individual, ou se preferir, que se caracterizam pelo fato de que entre os motivos ou razões que influem na decisão do legislador de outorgar-lhes dignidade penal se encontra a existência de interesses coletivos ou supra-individuais necessários para um correto funcionamento do sistema econômico imperante (p. ex., os delitos contra a propriedade industrial, delitos de concorrência desleal, a maior parte dos delitos societários)". MARTÍNEZ-BUJÁN PÉREZ, Carlos. Derecho penal..., cit., p. 119 (tradução livre). 
garantidora das expectativas e segurança do correto funcionamento dos contextos de interação $^{598}$.

Partindo dessa compreensão, DIAS pretende uma visão conciliadora na qual não nega o conceito de bem jurídico, mas procura justificar a punição imediata de certos comportamentos indesejados, em nome da proteção de bens coletivos, com vistas às presentes e futuras gerações:

Nesta medida acabamos por nos aproximar de certo modo, é verdade, da ideia de Stratenwerth segundo a qual a tutela dos grandes riscos e das gerações futuras pode em certos casos passar pela assunção de um direito penal do comportamento em que são penalizadas e punidas puras relações da vida como tais. Não se trata com isto, porém, de uma alternativa ao direito penal do bem jurídico: ainda aqui a punição imediata de certas espécies de comportamentos é feita em nome da tutela de bens jurídicos colectivos e só nesta medida se encontra legitimada. Desta maneira se manterá a fidelidade possível ao paradigma jurídico-penal iluminista que nos acompanha e se espera possa continuar a ser fonte de desenvolvimento e de progresso; e possa continuar assim a assumir o seu papel insubstituível na contenção dos megariscos da sociedade pós-industrial e na função tutelar dos interesses também das gerações futuras 599 .

A partir das reflexões de FEINBERG e KUHLEN, a construção teorética dos delitos cumulativos, a seu turno, também se revela como decorrente do contexto da sociedade do risco, tendo em vista que, como analisado, o ideal de vedação criminal a condutas indesejadas, as quais por si só são incapazes de afetação a um bem jurídico, mas que, uma vez disseminadas, poderiam denotar um abalo a um determinado interesse social, representa clara adoção política criminal de um critério de gerenciamento de riscos.

\footnotetext{
${ }^{598}$ BOTTINI, Pierpaolo Cruz. Crimes de..., cit., p. 104. Este autor ainda observa com propriedade que considerações similares são ofertadas na Espanha por GRACIA MARTÍN, o qual também se afasta do direito penal clássico: "Segundo o autor, o enfrentamento destas situações [novos desafios da sociedade do risco] não pode ser feito eficientemente somente por meio de alterações formais e quantitativas na legislação penal, mas exige uma ruptura material, substancial, em relação ao direito penal liberal. As novas regulações do direito penal deveriam estar fundadas em um sistema que transforme em ilícitos penais a totalidade das ações prejudiciais, perpetradas por meio das classes poderosas (...)". BOTTINI, Pierpaolo Cruz. Crimes de..., cit., p. 105. GRACIA MARTÍN defende uma sistemática penal voltada tanto para a proteção diante dos novos riscos, assim como para assegurar a manutenção da confiança social. Cf. GRACIA MARTÍN, Luis. Prolegómenos para..., cit., p. 64.

${ }^{599}$ DIAS, Jorge de Figueiredo. Direito penal..., cit., p. 154 (destaques originais).
} 
Relativamente ao pensamento de SILVA SÁNCHEZ, ainda que procure se revelar como uma possível alternativa ao Direito Penal da Sociedade do Risco - criticado pelo autor -, acaba por referendar o expansionismo penal em face dos novéis interesses difusos, vez que assimila a solução dentro da seara jurídico-criminal, ainda que parcialmente modificada por conta da proposta de vedação de cominação de pena privativa de liberdade. Apesar do esforço teórico do autor espanhol em assegurar o garantismo penal nas hipóteses tradicionais, fato é que sua proposta é pela criminalização difusa, entendendo ser papel do Direito Penal tutelar, ainda que sem sanção prisional, os interesses inéditos da sociedade do risco.

Afora a importante particularidade da apontada quebra sistêmica formulada por SILVA SÁNCHEZ, a crítica essencial aqui apresentada a cada um dos citados entendimentos desponta para um mesmo caminho, qual seja, o da necessidade de manutenção do conceito de bem jurídico-penal como referente material para a construção do Direito Penal. Esta compreensão é uma conquista da Ilustração representativa de um limite claro e seguro, portanto, um elemento crítico pertinente e racional, contra o arbítrio estatal, ainda não superada por qualquer outra proposta mais coerente.

A mesma linha argumentativa vale para crítica às reflexões de GARCÍA CAVERO em seu destacado trabalho sobre o Direito Penal Econômico. Para GARCÍA CAVERO, o ponto de partida para aferição da legitimidade do Direito Penal Econômico está na proposta de SILVA SÁNCHEZ, com apenas uma mudança de foco. Assim, a criação de um duplo sistema jurídico-criminal, preservando-se, por um lado, as garantias para os interesses tradicionais e, por outro lado, flexibilizando-se as regras de imputação e os princípios penais nas hipóteses difusas, como as infrações econômicas ${ }^{600}$, seria o mais racional, mas não por conta de uma justificação lastreada na sanção penal, ou seja, na conseqüência jurídica, e sim essencialmente em virtude do fato punível. Para o professor da Universidade de Piura:

(...) O Direito penal flexível fundamenta-se, em nossa opinião, na necessidade social de garantir a vigência de determinadas expectativas sociais essenciais independentemente da aparição de um resultado lesivo individualizado. (...) A

${ }^{600}$ SILVA SÁNCHEZ, Jesús-Maria. A expansão..., cit., pp. 145-146. 
proteção da configuração atual da economia somente pode ser alcançada de modo satisfatório pela assecuração da vigência de expectativas normativas em níveis que certamente não implicam ainda uma lesão individualizada. Apesar de se produzir com isso uma redução das garantias penais tradicionais vinculadas à exigência de uma lesão concreta, não há outra alternativa para manter normativamente a configuração atual do sistema econômico $(\ldots)^{601}$.

As oposições que se podem apresentar a esse pensamento do autor peruano são similares às dirigidas tanto ao lecionado por SILVA SÁNCHEZ quanto ao por JAKOBS. Além de uma inaceitável fissura sistêmica do ideário proposto, uma justificativa criminalizadora ancorada na proteção de expectativas sociais de conduta - como o faz JAKOBS - é carente de concretude e, desta maneira, insegura, abrindo-se espaço para o arbítrio estatal.

Ademais, o pensamento de GARCÍA CAVERO dá margem a uma gravíssima "terceira velocidade penal", pois admite em tese as mesmas respostas penais para os interesses clássicos e difusos, possibilitando-se, então, em última análise, a ocorrência de casos de prisão de indivíduos em nome da manutenção normativa da configuração do sistema econômico. Embora o doutrinador peruano faça a ressalva de que a pena de prisão somente deve ser utilizada para os casos de infrações econômicas com "suficiente gravidade" ${ }^{602}$, o critério oferecido, além de pouco claro, não muda o argumento fundamental de que a criminalização escora-se na mera necessidade de resguardo de expectativas sociais de condutas. Em nome dessa função, para fundamentar a necessidade de tutela da ordem econômica, afasta-se da teoria do bem jurídico, com o que não se concorda, conforme afirmado, pela ausência de conformação de um filtro claro e confiável ante o drástico meio repressivo jurídico-criminal.

Importa frisar, nesse ponto, que a defesa de manutenção da teoria do bem jurídico como critério jurídico penal de cunho material não significa, todavia, um necessário apego a um núcleo mínimo e imutável de bens jurídicos de natureza penal, vez que a sociedade evolui, devendo o Direito, por via de consequiência, acompanhá-la.

${ }^{601}$ GARCÍA CAVERO, Percy. Derecho penal..., cit., p. 108 (tradução livre).

${ }^{602}$ GARCÍA CAVERO, Percy. Derecho penal..., cit., p. 918. 
Dessa forma, ainda que não deixe de se inserir em certa medida num contexto de discurso de criminalização difusa, embora muito menos afeto a uma mudança radical de paradigma dogmático clássico relativamente aos demais citados, encontra-se a compreensão que não nega a teoria tradicional do bem jurídico, mas procura abrigar em seu bojo a tutela de parte dos interesses difusos, diante da modificação do contexto histórico ora vivenciado ${ }^{603}$. Ou seja, entende-se a teoria do bem jurídico como referencial interpretativo material do Direito Penal, todavia, sem limitar este ramo jurídico a um rol de interesses clássicos de viés exclusivamente individual, tal como preconizado pela Escola de Frankfurt.

\section{Assim é que MIRENTXU CORCOY BIDASOLO observa que no século XXI} existem outros interesses que o cidadão valora como indispensáveis para poder exercer efetivamente seus direitos fundamentais na vida social, não podendo, desse modo, o Direito Penal limitar-se aos bens jurídico-penais fundamentais de cunho individual, como vida, saúde, liberdade e patrimônio ${ }^{604}$. Para a professora catedrática da Universidade de Navarra:

(...) A situação de desamparo em que se encontra o cidadão frente às novas tecnologias e frente à complexidade tanto dos produtos de consumo como das instituições e organizações, tanto públicas como privadas, determina que o controle por parte do Direito penal destes âmbitos de atividade seja necessário e $\operatorname{legítimo~}^{605}$.

Neste sentido, não se nega a possibilidade do Direito Penal tutelar interesses supra-individuais ou difusos, desde que se mostrem essenciais para o livre desenvolvimento humano em sociedade e possuam ancoragem constitucional ${ }^{606}$. Afastando-se da visão do gerencialismo de riscos universais, presentes ou futuros, ou de regulação de funções administrativas, a verificação desse binômio encontra-se conforme

603 BECHARA nota que, embora o ideário do bem jurídico decorra do contexto político liberal, representativo de uma garantia da cidadania face ao arbítrio estatal, a evolução do Estado implicou na tutela de interesses de caráter coletivo, com vistas ao livre desenvolvimento do indivíduo, cf. BECHARA, Ana Elisa Liberatore Silva. Da teoria..., cit., pp. 229-230.

${ }^{604}$ CORCOY BIDASOLO, Mirentxu. Delitos de..., cit., p. 369, passim.

${ }^{605}$ CORCOY BIDASOLO, Mirentxu. Delitos de..., cit., p. 369.

${ }^{606}$ COSTA, Helena Regina Lobo da. Proteção penal..., cit., p. 16. Na doutrina brasileira, também admitindo a tutela penal de interesses difusos, mas com limites, cf., e.g.: SILVEIRA, Renato de Mello Jorge. Direito penal econômico..., cit., passim; SILVEIRA, Renato de Mello Jorge. Direito penal supra-individual..., cit., passim; BECHARA, Ana Elisa Liberatore Silva. Da teoria..., cit., p. 231. 
uma teoria liberal do bem jurídico, limitadora das fronteiras penais, sem a necessidade de um giro copérnico de teorização.

A ordem econômica insere-se nesta possibilidade de proteção, consubstanciando-se, como aqui adotado, na estrutura econômica da sociedade, representativa de um valor decorrente da vida individual e social, indispensável à sua manutenção e ao seu livre desenvolvimento. Na medida em que essa estrutura vai possibilitar os meios de subsistência do cidadão, assim como sua realização pessoal pelo trabalho e, porque não, pelo consumo, claramente se mostra como um valor fundamental passível de tutela penal.

Com os contornos da sociedade mundial de riscos avulta em importância o valor da ordem econômica, assegurando-se, em parte, aprioristicamente, a legitimidade do Direito Penal Econômico:

O Direito Penal Econômico tem sua legitimidade assegurada pela própria sociedade de risco globalizada. A importância assumida pela Economia, nesse contexto, parece inegável. Parece certo que se aceite uma incriminação de condutas em âmbito prévio, a fim de se assegurar a sua proteção. Mas ainda resta a colocação sobre quais seriam os limites a serem impostos para formatação desse novo Direito. Se é certo que os limites normalmente encontrados no Direito Penal clássico devem ser aqui obedecidos, são de se ver algumas diferenças e distanciamentos encontrados nas situações de perigo abstrato $^{607}$.

Há que se frisar, então, que isso não significa que o Direito Penal Econômico será sempre legítimo, estando toda e qualquer tutela com esse fim preliminarmente respaldada em nome do importante interesse que a cerca. Em outras palavras, nem toda manifestação penal econômica é por si mesma legítima. Aliás, em face da ausência de um entendimento exaustivo quanto à própria noção de bem jurídico, consoante observa ANA ELISA LIBERATORE SILVA BECHARA, fica comprometida a possibilidade de afirmação categórica prévia de legitimidade de uma proposição penal, havendo, isto sim, o oferecimento de um critério negativo de deslegitimação ${ }^{608}$.

${ }^{607}$ SILVEIRA, Renato de Mello Jorge. Direito penal econômico..., cit., p. 159.

${ }^{608}$ BECHARA, Ana Elisa Liberatore Silva. Da teoria..., cit., p. 384 e ss., passim. 
Os limites da criminalização econômica vão despontar então, para além da identificação do caro valor em jogo, com escora constitucional, na estrutura típica utilizada e na eficácia desse mecanismo de proteção, elementos cujas aferições em grande parte das vezes vão demonstrar tipos penais ilegítimos ${ }^{609}$, recomendando-se a utilização de outro meio de tutela, como o Direito Administrativo Sancionador.

\subsection{A tutela da ordem econômica - finalidade e eficiência: deslegitimação do Direito Penal}

Se de um lado se constata que a ordem econômica é um bem jurídico com dignidade penal, pelas razões expostas, o que necessariamente se leva a concluir que nem sempre a expansão do Direito Penal é disfuncional, de outro, verifica-se que a legislação penal econômica efetivamente produzida no contexto da sociedade do risco encontra sérias dificuldades de validade e de efetividade, abusando do caráter simbólico do Direito Penal, devendo ser desta maneira repensada. Na prática, o que se afere em países como o Brasil é a administrativização do Direito Penal na seara econômica, o que é uma característica negativa, visto que consagradora de ilegítima utilização deste gravoso meio de intervenção do Estado.

Mais concretamente, o que se constata de lege lata é a larga utilização do ramo jurídico-criminal com fins de ordenação de interesses administrativos, buscando-se forçar condutas ou cercear por esta drástica via comportamentos econômicos indesejados, o que não é o papel do Direito Penal.

Pródigo exemplo dessa postura encontra-se em nossa legislação quanto aos crimes contra o sistema financeiro, Lei n. 7.492/1986, diploma no qual em inúmeros tipos penais perfaz-se o tipo objetivo com o simples não-atendimento a normas do Banco Central do Brasil ou à legislação atinente ao mercado de valores mobiliários, pouco

\footnotetext{
609 "Embora pareça correta a assertiva de que o Direito penal não pode se mostrar alheio a tudo o que está a se dar no mundo, as formulações atuais do Direito Penal Econômico, por onde se procura um controle social, mormente através de termos abstratos e em forma antecipada, destoantes de toda a construção liberal, parecem um tanto temerárias". SILVEIRA, Renato de Mello Jorge \& SALVADOR NETTO, Alamiro Velludo. A tutela penal..., cit., p. 379.
} 
importando a aferição concreta de um prejuízo patrimonial. Dentre outros artigos da lei em foco, exemplificativamente, sinalizam nesse sentido as seguintes normas primárias: artigo $7^{\circ}$, II: "Emitir, oferecer ou negociar, de qualquer modo, títulos ou valores mobiliários: (...) II - sem registro prévio de emissão junto à autoridade competente, em condições divergentes das constantes do registro ou irregularmente registrados; (...)", artigo 10: "Fazer inserir elemento falso ou omitir elemento exigido pela legislação em demonstrativos contábeis de instituição financeira, seguradora ou instituição integrante do sistema de distribuição de títulos de valores mobiliários" e artigo 12: "Deixar, o exadministrador de instituição financeira, de apresentar, ao interventor, liquidante, ou síndico, nos prazos e condições estabelecidas em lei as informações, declarações ou documentos de sua responsabilidade". Importante notar ainda que, a despeito do forte viés administrativo, à exceção do crime previsto no artigo 21, todos os demais tipos penais da Lei n. 7.492/86 são punidos com pena de reclusão, ensejando grave cerceamento penal pelo desatendimento a prescrições de interesse da Administração Pública.

Primeiramente, insta observar que "(...) o tipo penal não pode tutelar a mera desobediência à administração, devendo-se sempre verificar se há, concomitantemente, afetação do bem jurídico" ${ }^{\prime 610}$. Neste influxo, afere-se a primeira e fundamental incompatibilidade da assessoriedade administrativa com a construção típica do Direito Penal Econômico.

Dessa maneira, na criação da norma penal econômica, no mais das vezes já se parte de um pressuposto equivocado e, portanto, ilegítimo, agressor do princípio da proteção a um bem jurídico com dignidade penal, ou ainda da subsidiariedade penal, o que já indica a necessidade de rechaço do Direito Penal em tais situações. Todavia, além da perniciosa premissa, constata-se, no mais das vezes, a inadequação estrutural do Direito Penal Econômico, o que também compromete sua racionalidade.

\footnotetext{
${ }^{610}$ COSTA, Helena Regina Lobo da. Proteção penal..., cit., p. 153. No mesmo sentido, REALE JÚNIOR: “(...) não devem ser erigidos à condição de dignidade penal os interesses da Administração na obediência de normas regulamentares, sem referência a valor de relevo social, por exemplo, a não-notificação de modificação do excipiente de um remédio, sem qualquer risco à saúde e até mesmo com melhoria do produto. De idêntico modo, não podem ter proteção penal as políticas estatais convenientes à consecução de objetivos administrativos. Também não podem receber tutela penal a observância de regulamentos, como a incriminação do uso de agrotóxicos sem seguir as instruções, sendo o ilícito penal 'criado mais para organizar do que para proteger'”. REALE JÚNIOR, Miguel. Instituições de ..., cit., pp. 24-25.
} 
Com isso quer se significar que os meios utilizados na construção dos mais diversos tipos penais são por demais inseguros e porosos, a comprometer a via penal por meio de sua técnica. Isto é, para além das dificuldades ínsitas de regramento do ambiente econômico, complexo e dinâmico por sua própria natureza, empregam-se meios duvidosos, de larga incerteza jurídica, na técnica legislativa tipificadora.

O abuso na utilização das técnicas de crimes de perigo abstrato ${ }^{611}$, de tipos $\operatorname{abertos}^{612}$, de crimes omissivos ${ }^{613}$, de crimes culposos ${ }^{614}$, de normas penais em branco ${ }^{615}$, com abuso de remissões administrativas, erige uma sistemática lastreadora do arbítrio estatal, vilipendiando-se a segurança jurídica por meio da vulneração dos princípios fundamentais da legalidade e lesividade penais. $O$ referente material dos tipos incriminadores vê-se esvaziado ${ }^{616}$.

\footnotetext{
${ }^{611}$ Como exemplos, temos o artigo 63 da Lei 8.078/1990 (omissão de dizeres ou de sinais ostensivos sobre a nocividade ou periculosidade de produtos, nas embalagens, nos invólucros, recipientes ou publicidade) ou o artigo 70 da mesma lei (emprego, na reparação de produtos, de peças ou componentes de reposição usados, sem autorização do consumidor).

${ }^{612}$ V.g., caso dos crimes de divulgação de informação falsa ou prejudicialmente incompleta sobre instituição financeira e de gestão temerária de instituição financeira, previstos, respectivamente, nos artigos $3^{\circ} \mathrm{e} 4^{\circ}$, parágrafo único, da Lei 7.492/1986, bem como de uso de informação relevante no mercado de capitais (insider trading - artigo 27-D da Lei $\mathrm{n}^{\circ} 10.303 / 2001$ ).

${ }^{613}$ São as hipóteses previstas no parágrafo único do artigo 10 da Lei Complementar no 105/2001 (omissão ou retardo injustificado de informações requeridas nos termos da legislação sobre operações financeiras) ou no artigo 73 da Lei $n^{\circ}$ 8.078/1990 (deixar de corrigir imediatamente informação sobre consumidor constante de cadastro, banco de dados, fichas ou registros que sabe ou deveria saber inexata).

${ }^{614} \S 2^{\circ}$ do citado artigo 63 da Lei $n^{\circ}$ 8.078/1990 (modalidade culposa acerca de omissões sobre malefícios de produtos) e $\S 2^{\circ}$ do artigo 66 do mesmo diploma (modalidade culposa de afirmações inverídicas sobre produtos ou serviços).

${ }^{615}$ Caso do artigo $1^{\circ}$ da Lei $n^{\circ}$ 8.176/1991 (relativo ao exercício de atividades econômicas de combustíveis em desacordo com as normas estabelecidas em lei), do artigo 65 da Lei 8.078/1990 (execução de serviço de alto grau de periculosidade, contrariando determinação de autoridade competente) ou ainda do artigo 22 da Lei $\mathrm{n}^{\circ}$ 7.492/1986 (evasão de divisas). Sobre este último, paradigmático exemplo, consoante entendemos, observe-se que, além de inúmeros elementos normativos do tipo ("operação de câmbio", "divisas", "evasão de divisas", "moeda" e "repartição pública") e cláusulas penais em branco ("não autorizada", "sem autorização legal" e "não declarados à repartição federal competente"), a quantidade de normas administrativas que vem sendo editadas em torno do tipo (caso das Circulares do Banco Central ${ }^{\circ}$ s 3.071/01, 3.181/03, 3.225/04, 3.278/04, 3.313/05, 3.345/06, 3.384/08, 3.442/09 e 3.496/10, e, por fim, da Resolução do Conselho Monetário Nacional $\mathrm{n}^{\circ}$ 3.854/10) denota violação à taxatividade penal, indicando, ademais, que o tema é muito mais afeto à seara adminsitrativa. Sobre o tema, v. SCHMIDT, Andrei Zenkner \& FELDENS, Luciano. O crime de evasão de divisas. Rio de Janeiro: Lúmen Júris, 2006, passim; SCHMIDT, Andrei Zenkner \& FELDENS, Luciano. Os ativos declaráveis perante o Banco Central e os limites normativos do art. 22, parágrafo único, da Lei $\mathrm{n}^{\circ}$ 7.492/86. Boletim IBCCRIM, n. 217, v. 18, dez. 2010, pp. 2-3; PRADO, Luiz Regis. Direito penal econômico. São Paulo: Revista dos Tribunais, 2004, pp. 329-339.

${ }^{616}$ SGUBBI, Filippo. El delito..., cit., p. 72.
} 
Ainda, analisando as dificuldades de estabelecimento ou comprovação de relações de causalidade entre conduta e resultado nos crimes ambientais, similares aos crimes contra a ordem econômica, refere-se com propriedade COSTA que:

\begin{abstract}
A imputação se torna ainda mais problemática quando tiver de ser realizada em contextos empresariais. Partindo-se do pressuposto inafastável em direito penal de que o ilícito é produto do agente e não de outras pessoas, verifica-se que nas atividades empresariais há uma complexa separação de tarefas, de informações e de funções que acaba por tornar muito difícil a imputação pessoal conforme exigida pelo direito penal ${ }^{617}$.
\end{abstract}

Para superação de tais dificuldades, parte da doutrina sustenta a utilização da responsabilização da pessoa jurídica, o que é controvertido em termos jurídico-penais, fundamentalmente em razão do princípio da culpabilidade, mas não apresentaria qualquer problemática no campo administrativo.

Ademais, a tutela penal e administrativa, concomitantemente, pode muitas vezes representar um bis in idem. Conforme nota REALE JÚNIOR ao, e.g., confrontar os tipos penais e as infrações administrativas nas Leis 8.137/90 e 8.884/94, ambos têm em comum a tutela do mesmo bem jurídico, por meio da vedação a condutas em grande parte semelhantes ${ }^{618}$. Nesse diapasão, a punição em ambas as esferas pela mesma conduta representa a consagração de uma dupla punição num contexto de poder de punir estatal que é único. Tal é reconhecido em países como Alemanha, Itália, Espanha e Portugal ${ }^{619}$.

Outrossim, FERRARI afirma com propriedade que a adoção exclusiva da tutela administrativa no campo econômico tem o condão de afastar a morosidade e a burocracia do sistema penal, o que certamente valoriza a eficiência e evita a impunidade nas indesejadas infrações econômicas:

A razão da adoção dessa visão administrativa, forte no campo das questões econômicas, visa cada vez mais evitar a interferência penal no âmbito econômico, resultando não apenas eliminar ao máximo a morosidade e a burocracia do sistema penal, revalorizando os agentes do Estado, e, por via de consequiência, toda a sociedade e a ordem econômica; não havendo como deixar de ter a percepção de que vivemos em um âmbito, onde a proteção à ordem

${ }^{617}$ COSTA, Helena Regina Lobo da. Proteção penal..., cit., p. 154.

${ }^{618}$ REALE JÚNIOR, Miguel. Despenalização no..., cit., p. 117 e ss.

${ }^{619}$ COSTA, Helena Regina Lobo da. Proteção penal..., cit., p. 242. 
econômica articula-se, em nosso ordenamento, em uma visão, sistêmica de raiz constitucional $^{620}$.

Há, portanto, incompatibilidades estruturais que apontam o Direito Administrativo Sancionador, ao invés do Penal, como, no geral, o melhor caminho na tutela da ordem econômica, ensejando ampla descriminalização de condutas nestes casos, ressalvadas as hipóteses mais graves cerceadas por meio de tipos claros e precisos.

\subsection{As opções jurídicas como lege ferenda}

Como visto, dentre as opções jurídicas ofertadas pela doutrina como alternativa ao Direito Penal na tutela de interesses difusos, como é o caso da ordem econômica, temos o Direito de Intervenção, o Direito penal de duas velocidades e o Direito Administrativo Sancionador.

A proposta de HASSEMER quanto a um Direito de Intervenção, como visto, carece de maior concretude. Assim, embora dê sinais de aproximação com o ideário do Direito Administrativo Sancionador como um sistema de contra-ordenação a ser utilizado para o regramento dos novéis problemas sociais, o fato é que não há uma delimitação precisa capaz de insculpir uma sistematização segura e eficaz. Por essa razão, não se vislumbra maior possibilidade de justificação para sua defesa.

A proposta de SILVA SÁNCHEZ, por sua vez, consoante o asseverado mais de uma vez, representa quebra sistêmica e mantém a problemática do abuso na utilização simbólica do Direito Penal, com o que não se concorda. O fato de se defender a nãoutilização da sanção prisional para a segunda velocidade penal não mitiga os demais característicos gravosos e infamantes deste drástico meio de tutela jurídica. Neste sentido, também se rechaça este posicionamento.

O Direito Administrativo Sancionador, por sua vez, representa uma alternativa coerente com a defesa de novos e complexos interesses sociais, condizente com os característicos de um Estado Democrático de Direito. Num primeiro plano, nota-se que

${ }^{620}$ FERRARI, Eduardo Reale. Legislação penal..., cit., p. 295. 
o regramento de funções estatais, escopo de diversas normas de cunho econômico, é atribuição típica do Direito Administrativo, não do ramo penal.

Ainda, o meio de tutela flexibilizado que se procura impor relativamente às infrações econômicas somente pode ser admissível nesse âmbito, jamais na seara penal. Tal meio flexibilizado, ademais, é condizente com a dinamicidade e complexidade da atividade econômica, e enormemente distante da estrutura jurídico-penal, com seus característicos de estrita legalidade e taxatividade.

Também a sanção de cunho econômico, assim como a responsabilidade penal da pessoa jurídica, são muito mais afetas ao ramo administrativo do que à sistemática penal.

Contudo, embora haja ampla indicação de que as infrações à ordem econômica devam, preferencialmente, ser tuteladas pelo Direito Administrativo, entende-se que este há de ser reestruturado com vistas à sua maior eficiência, consoante propostas concretas como aquelas trazidas, por exemplo, em nossa doutrina por REALE JÚNIOR, FERRARI e COSTA. Não se nega que o Direito Penal possa oferecer tipos infracionais econômicos legítimos. Mas tal somente ocorrerá respeitados critérios de verificação consistentes na verificação do bem jurídico ordem econômica, em sua adequação estrutural e constatação de eficiência deste grave meio de cerceamento, respeitando-se a idéia de ultima ratio. Do contrário, a única opção legítima é a descriminalização, abrindo-se a possibilidade de outros meios para pacificação social. 


\section{CONCLUSÕES}

1. Na história geral, a relação entre Direito Penal e economia apresentou as fases de mero casuísmo de tratamento, que perdurou da Antigüidade à Idade Moderna; de proteção ao modelo econômico liberal, que teve no Sherman Act a sua consagração; de assecuração da política do Estado do Bem-Estar Social e de diminuição do papel do Estado na economia, para a função de agente regulador, tendo no Sarbanes-Oxley Act seu ápice.

2. Desde o período de busca por proteção ao modelo liberal até os dias atuais, a repressão penal de ações de interesse da economia vem se ampliando, embora por fundamentos diversos.

3. No Brasil, não se constata correspondência com as fases internacionais, até recentemente. A partir da segunda metade do século XX, todavia, começa a despontar a criminalização econômica no país, havendo uma radicalização nos anos 90, sem qualquer sistematização.

4. Em face da exasperação dessa forma de criminalização, faz-se fundamental delimitar o significado, o alcance e a funcionalidade da ligação entre Direito Penal e economia, com vistas à reflexão quanto à sua legitimidade em um Estado Democrático de Direito.

5. O intérprete deve então, preliminarmente, atentar-se sobre a conceituação de Direito Penal Econômico, o que é controvertido na doutrina.

6. A partir dos estudos de SUTHERLAND, com cunho criminológico, identificou-se o tema com seu autor, tido como homem de negócios (de "colarinho branco"), em contraposição ao criminoso tradicional.

7. Também há o entendimento que reconhece o Direito Penal Econômico como um Direito Penal de empresa, isto é, perpetrado por meio de empresas. 
8. A partir do posicionamento anterior, há ainda doutrina que concebe o Direito Penal Econômico como aquele que engloba infrações penais perpetradas de modo profissional no bojo de uma atividade econômica (occupational crime).

9. Para TIEDEMANN, segundo uma compreensão estrita, o intuito do Direito Penal Econômico seria o de proteger os objetivos da planificação estatal da economia. Já em sentido amplo, que ganha a adesão do autor alemão, o Direito Penal Econômico compreenderia as violações à atividade interventora e regulatória do Estado na economia, as infrações aos demais bens jurídicos supra-individuais da vida econômica, os quais, por necessidade conceitual, transcendem os bens jurídicos individuais, e, finalmente, os delitos patrimoniais clássicos, quando estes se dirigem contra patrimônios supra-individuais ou quando constituem abuso de medidas e instrumentos da vida econômica.

10. O único critério seguro e legítimo num Estado Democrático de Direito, todavia, é aquele que identifica na intervenção jurídico-penal a proteção a interesses essenciais para a pacífica convivência social que não podem ser tutelados de outro modo menos gravoso. Em outras palavras, há de se respeitar os princípios da intervenção penal mínima e da exclusiva proteção de bens jurídicos.

11. O bem jurídico-criminal tutelado por uma norma penal econômica legítima é a ordem econômica, interesse supra-individual consistente na estrutura de produção, circulação e distribuição de riquezas, representativa de um valor decorrente da vida individual e coletiva, indispensável à sua manutenção e livre desenvolvimento.

12. Na identificação do bem jurídico ordem econômica, a confiança mostra-se como importante marco valorativo, de cunho crítico, capaz de delimitar a tipificação válida, vez que um sistema monetarizado de livre mercado necessita de expectativas sociais mínimas para seu regular funcionamento.

13. Não obstante a possibilidade de verificação de tutela penal da ordem econômica legítima, a criminalização econômica comumente decorrente da sociedade mundial do risco revela graves problemas estruturais, sendo que complexas condutas são 
vedadas por meio de formulações tipificadoras antecipatórias, pouco consistentes e com caráter de meio de conformação de comportamentos de alçada administrativa, consagrando-se a administrativização do Direito Penal.

14. Assim é que as formulações no mais das vezes utilizadas são de perigo abstrato, tipos abertos, delitos culposos, tipos omissivos e normas penais em branco, fomentando-se um Direito Penal meramente simbólico.

15. Num contexto de intervenção penal mínima, após a identificação do bem jurídico penalmente tutelado, o subseqüente vetor analítico a nortear o intérprete é o princípio da lesividade, ou ofensividade, consistente, consoante o pensamento clássico, na relevante afetação do interesse protegido.

16. A compreensão de lesividade como transgressão ao ordenamento, erigida como uma alternativa à concepção tradicional de lesividade, é ilegítima, pois entende a infração penal como uma mera violação de dever, com vistas à proteção da vigência do ordenamento, o que não se afigura como um parâmetro seguro para limitação do poder de punir do Estado.

17. As dificuldades de identificação do bem jurídico tutelado e do princípio da lesividade na delinqüência econômica enseja a defesa de afastamento de rigorismos para a verificação das práticas abusivas, o que já desponta melhor adequação de tutela por outro ramo do Direito.

18. Exemplo de utilização de critérios flexíveis voltados à efetividade da proteção, no caso brasileiro, encontra-se da atuação do Conselho Administrativo de Defesa Econômica - CADE. Tais, parâmetros, contudo, são inadmissíveis na seara penal.

19. A teoria dos delitos cumulativos liga-se à idéia de punição criminal a condutas que são de per se incapazes de afetação a interesses jurídico-penais, mas que, por critérios político-criminais, são vedadas, uma vez que sua prática disseminada exponencial denotaria abalo (por dano ou por perigo) a um determinado bem jurídico. Nesse sentido, 
esta teoria poderia justificar a tutela penal econômica de cunho antecipatório dos dias atuais.

20. Entretanto, o ideário da cumulatividade delitiva não se revela compatível com o paradigma de um Direito Penal liberal, escorado na proteção a um bem jurídico essencial para a coexistência social, bem como da fundamentação nos princípios da ofensividade, da proporcionalidade e da culpabilidade, critérios limitadores da incidência repressiva. Este o quadro normativo que constitui o fundamento de validade do Direito Penal nas democracias e que não encontra ressonância na teoria em foco, atingindo, dessa maneira, sua legitimidade. A construção em foco é, todavia, coerente com a seara administrativa.

21. Diante do expansionismo penal das últimas décadas, onde se insere a ampliação do Direito Penal Econômico, erigindo-se uma intervenção penal meramente simbólica, com dificuldades estruturais e ausência de legitimidade, despontam na doutrina propostas de equacionamento. Neste contexto, destacam-se os pensamentos da Escola de Frankfurt, do Direito de Intervenção, do Direito Penal de duas velocidades e do Direito Administrativo Sancionador.

22. A proposta da Escola de Frankfurt, qual seja, de manutenção do Direito Penal a um núcleo mínimo com referencial direto ao indivíduo, é inviável uma vez que ignora a evolução social.

23. Ainda dentro do contexto a Escola de Frankfurt há a proposta do Direito de Intervenção de HASSEMER, a qual, se por um lado possui os méritos de busca de salvaguarda do Direito Penal em contornos legítimos e de não fechar os olhos para as novas problemáticas sociais, de outro carece de maior concretude, não havendo uma delimitação.

24. A proposta de SILVA SÁNCHEZ, de um Direito Penal de duas velocidades, representa uma quebra sistêmica e parte da premissa equivocada de considerar como de relevo penal apenas normas que cominem sanção prisional, ignorando todos os 
demais consectários do grave meio de intervenção jurídico-criminal. Ademais, abre caminho para o expansionismo penal.

25. Um Direito Administrativo reformulado, de cunho sancionador, com garantias materiais e processuais, revela-se como um caminho legítimo e mais eficaz para a tutela da ordem econômica. Dessa maneira, de um lado, uma ampla descriminalização das infrações econômicas, deve vir acompanhada, de outro, de uma reestruturação da seara administrativa, sem se perder de vista, em ambos os aspectos, os contornos liberais ínsitos a um Estado Democrático de Direito. 


\section{BIBLIOGRAFIA}

AGUILLAR, Fernando Herren. Direito econômico: do direito nacional ao direito supranacional. São Paulo: Atlas, 2009.

ALCÁCER GUIRAO, Rafael. La protección del futuro y los daños cumulativos. Revista Electrónica de Ciencia Penal y Criminología, Granada, n. 4, 2002. Disponível em: $<$ http://criminet.ugr.es/recpc>. Acesso em 30/06/2010.

. Sobre el concepto de delito: ¿Lesión del bien jurídico o lesión de deber? Buenos Aires: Ad-Hoc, 2003.

ALEXANDER, Cindy R. Corporate crime, markets and enforcement: a review. New perspectives on economics crime. Northampton: Edward Elger, 2004.

AMARAL, Cláudio do Prado. Bases teóricas da ciência penal contemporânea: dogmática, missão do direito penal e política criminal na sociedade de risco. São Paulo: IBCCRIM, 2007.

ANDRADE, Manuel da. Consentimento e acordo em direito penal. Coimbra: Coimbra, 1991.

- Contributo para o conceito de contra-ordenação (a experiência alemã). In: INSTITUTO DE DIREITO PENAL ECONÓMICO E EUROPEU - FACULDADE DE DIREITO DA UNIVERSIDADE DE COIMBRA. Direito penal económico e europeu: textos doutrinários. Coimbra: Coimbra, 1998, V. I, pp. 75-107.

ANGIONI, Francesco. Il pericolo concreto come elemento della fattispecie penale - la struttura oggettiva. Milano: Giuffrè, 1994.

AQUINO, Rubim Santos Leão de; FRANCO, Denize de Azevedo \& LOPES, Oscar Guilherme Pahl Campos. História das sociedades: das comunidades primitivas às sociedades medievais. Rio de Janeiro: Ao Livro Técnico, 1980.

ARAUJO JÚNIOR, João Marcello de. Dos crimes contra a ordem econômica. São Paulo: Revista dos Tribunais, 1995.

Os crimes contra o sistema financeiro no esboço de nova parte especial do Código

Penal de 1994. Revista Brasileira de Ciências Criminais, São Paulo, n. 11, 1995, pp. 
$145-165$.

O direito penal econômico. Revista Brasileira de Ciências Criminais, São Paulo, n. 25, 1999, pp. 142-156.

ASCENSÃO, José de Oliveira. Sociedade da informação e mundo globalizado. In: Globalização e Direito - Boletim da Faculdade de Direito, Coimbra, Stvdia Ivridica 73, colloquia 12, 2003, pp.163-180.

AZEVEDO, Luiz Carlos de. Introdução à história do direito. São Paulo: Revista dos Tribunais, 2007.

BACIGALUPO, Enrique (Dir.). Derecho penal económico. Buenos Aires: Hamurabi, 2004.

BAJO FERNÁNDEZ, Miguel \& BACIGALUPO SAGGESE, Silvina. Derecho penal económico. Madrid: Centro de Estudios Ramón Areces, 2001.

BALDAN, Édson Luís. Fundamentos do direito penal econômico. Curitiba: Juruá, 2005.

BARATTA, Alessandro. Funções instrumentais e simbólicas do direito penal. Lineamentos de uma teoria do bem jurídico. Trad. Ana Lúcia Sabadell. Revista Brasileira de Ciências Criminais, São Paulo, n. 5, 1994, pp. 5-24.

Principios del derecho penal mínimo: para una teoría de los derechos humanos como objeto y limite de la ley penal. Doctrina Penal, Buenos Aires, ano 10, 1987, pp. 623650 .

BASTOS, Celso Ribeiro. Curso de direito constitucional. São Paulo: Malheiros, 2010.

BATISTA, Nilo. Introdução crítica ao direito penal brasileiro. Rio de Janeiro: Revan, 1990.

BAUMAN, Zygmunt. Vida líquida. Trad. Carlos Alberto Medeiros. Rio de Janeiro: Zahar, 2009.

BECCARIA, Cesare. Dos delitos e das penas. Trad. Torrieri Guimarães. São Paulo: Hemus, 1996.

BECHARA, Ana Elisa Liberatore S. Delitos de acumulação e racionalidade da intervenção penal. Boletim IBCCRIM, São Paulo, n. 208, março/2003, pp. 3-5. 
. Direito penal e economia: tutela penal da ordem econômica. Revista da Faculdade de Direito de São Bernardo do Campo, São Bernardo do Campo, ano 12, n. 14, 2008, pp. 63-75.

. Manipulação genética humana e direito penal. Porto Alegre: Zouk, 2007.

. O rendimento da teoria do bem jurídico no direito penal atual. Revista Liberdades, São Paulo, v. 1, n. 1, mai./ago. 2009, pp. 16-29.

. Da teoria do bem jurídico como critério de legitimidade do direito penal, mimeo, São Paulo, Tese de Livre Docência, Faculdade de Direito da Universidade de São Paulo, 2010.

BECK, Ulrich. O que é globalização? Equívocos do globalismo: respostas à globalização. Trad. André Carone. São Paulo: Paz e Terra, 1999.

. La sociedad del riesgo: hacia una nueva modernidad. Trad. Jorge Navarro, Daniel Jiménez e Maria Rosa Borras. Barcelona: Paidos, 1998.

BERCOVICI, Gilberto. Constituição econômica e desenvolvimento: uma leitura a partir da constituição de 1988. São Paulo: Malheiros, 2005.

. Desigualdades regionais, estado e constituição. São Paulo: Max Limonad, 2003.

A Problemática da Constituição Dirigente: Algumas Considerações sobre o Caso Brasileiro. Revista de Informação Legislativa, Brasília, Senado Federal, n. 142, abr.jun. 1999, pp. 35-51.

BERRUEZO, Rafael et all. Derecho penal económico. Montevideo-Buenos Aires: B de F, 2010.

BERSTEIN, Serge et all. História do século XX: volume I: 1900-1945: o fim do "mundo europeu”. Trad. Fernando Santos. São Paulo: Companhia Editora Nacional, 2007.

- História do século XX: volume III: de 1973 aos dias atuais: a caminho da globalização e do século XXI. Trad. Fernando Santos. São Paulo: Companhia Editora Nacional, 2007.

BITENCOURT, Cezar Roberto. Tratado de direito penal: parte geral. São Paulo: Revista dos Tribunais, 2006, V. I.

\& SCHMIDT, Andrei Zenkner. Direito penal econômico aplicado. Rio de Janeiro: 
Lumen Iuris, 2004.

BOIX REIG, Javier (Dir.) \& LLORIA GARCIA, Paz (Coord.). Diccionario de derecho penal económico. Madrid: Iustel, 2008.

BONAVIDES, Paulo. Curso de direito constitucional. São Paulo: Malheiros, 2009.

BOTTINI, Pierpaolo Cruz. Crimes de perigo abstrato e princípio da precaução na sociedade de risco. São Paulo: Revista dos Tribunais, 2007.

BRANCO, Fernando Castelo. Reflexões sobre o acordo de leniência: moralidade e eficácia na apuração dos crimes de cartel. In: VILARDI, Celso Sanchez; PEREIRA, Flávia Rahal Bresser \& DIAS NETO, Theodomiro (Coords.). Crimes econômicos e processo penal. São Paulo: Saraiva, 2008, pp. 137-165.

BRANDÃO, Nuno. Questões contra-ordenacionais suscitadas pelo novo regime legal da medição de seguros. In: Direito penal económico e europeu: textos doutrinários. Coimbra: Coimbra, 2009, v. III, pp. 721-735.

BRASIL. Advocacia Geral da União. Procuradoria-Geral Federal. Procuradoria Federal CADE. Parecer PROCADE n. 066/2008. Parecer do Procurador Marcos Benacchio.

BRASIL. Advocacia Geral da União. Procuradoria-Geral Federal. Procuradoria Federal CADE. Parecer PROCADE n. 365/2009. Parecer do Procurador Diogo Thomson Andrade.

BRASIL. Conselho Administrativo de Defesa Econômica - CADE. Procedimento Administrativo n. 08000.020787/96-62. Voto da Conselheira Lúcia Helena Salgado e Silva.

BRASIL. Conselho Administrativo de Defesa Econômica - CADE. Ato de Concentração n. 08012.001697/2002-89. Voto do Conselheiro Thompson Andrade.

BRASIL. Conselho Administrativo de Defesa Econômica - CADE. Processo Administrativo n. 8012.002127/02-14. Voto do Conselheiro Luiz Carlos Delorme Prado.

BRASIL. Conselho Administrativo de Defesa Econômica - CADE. Processo Administrativo n. 08012.002299/2000-18. Voto do Conselheiro Afonso Arinos de Mello Franco Neto.

BRASIL. Conselho Administrativo de Defesa Econômica - CADE. Procedimento Administrativo n. 08012.004712/2000-89. Voto do Conselheiro Roberto Augusto Castellanos Pfeiffer. 
BRAVO, Jorge dos Reis. A tutela penal dos interesses difusos: a relevância criminal na proteção do ambiente, do consumo e do patrimônio cultural. Coimbra: Coimbra Editora, 1997.

BÜLlESBACH, Alfred. Princípios de teoria dos sistemas. In: KAUFMANN, Arthur \& HASSEMER, Winfried (Orgs.). Introdução à filosofia do direito e à teoria do direito contemporâneas. Trad. Marcos Keel e Manuel Seca de Oliveira. Lisboa: Fundação Calouste Gulbenkian, 2002, pp. 409-442.

BUSTOS RAMÍREZ, Juan. Introducción al derecho penal. Bogotá: Temis, 1994.

CAMARGO, Antonio Luis Chaves. Imputação objetiva e direito penal brasileiro. São Paulo: Cultural Paulista, 2002. . Tipo penal e linguagem. Rio de Janeiro: Forense, 1981.

CAMPILONGO, Celso Fernandes. $O$ direito na sociedade complexa. São Paulo: Max Limonad, 2000.

CANOTILHO, José Joaquim Gomes. Constituição dirigente e vinculação do legislador: contributo para a compreensão das normas constitucionais programáticas. Coimbra: Coimbra, 2001.

CARO CORIA, Dino Carlos. Derecho penal del ambiente - delitos y técnicas de tipificación. Lima: Horizonte, 1999.

- Sociedades de riesgo, bienes jurídicos coletivos y reglas concursales para la determinación de la pena en los delitos de peligro com verificación de resultado lesivo. Revista Peruana de Ciencias Penales, n. 9, 1999, pp. 177-219.

CEREZO MIR, José. Derecho penal - parte general. São Paulo: Revista dos Tribunais; Lima: ARA Editores, 2007.

- Sanções penais e administrativas no direito espanhol. Revista Brasileira de Ciências Criminais, São Paulo, n. 2, 1993, pp. 27-40.

CERVINI, Raúl. Derecho penal económico - concepto y bien jurídico. Revista Brasileira de Ciências Criminais, São Paulo, n. 43, 2003, pp. 81-108.

. Derecho penal económico democrático: hacia una perspectiva integrada. In: Direito penal econômico: análise contemporânea. VILARDI, Celso Sanchez; PEREIRA, Flávia Rahal Bresser \& DIAS NETO, Theodomiro (Coords.). São Paulo: Saraiva, 2009, pp. 3- 
60.

Incidencia de las "mass media" en la expansión del control penal en latinoamérica.

Revista Brasileira de Ciências Criminais, São Paulo, n. 5, pp. 37-54.

- Os processos de descriminalização. Trad. Eliana Granja, Jeni Vaitsman, José

Henrique Pierangeli e Maria Alice Andrade Leonardi. São Paulo: Revista dos Tribunais, 2002.

CLINARD, Marshall B. Black market: a study of white collar crime. Montclair: Patterson Smith, 1969.

\& YAGER, Peter C. Corporate crime. Somerset: Transaction, 2005.

COELHO, Inocêncio Mártires. Princípios da ordem econômica e financeira. In: MENDES, Gilmar Ferreira; COELHO, Inocêncio Mártires \& BRANCO, Paulo Gustavo Gonet. Curso de direito constitucional. São Paulo: Saraiva, 2009, pp. 1405-1415.

COELHO, Marina Pinhão. Ensaio sobre a tipicidade penal objetiva em um sistema teleológico-racional. Tese (Doutorado em Direito). Faculdade de Direito da Universidade de São Paulo, São Paulo, 2006.

COELHO, Yuri Carneiro. Bem jurídico-penal. Belo Horizonte: Mandamentos, 2003.

CORCOY BIDASOLO, Mirentxu. Delitos de peligro y protección de bienes jurídicopenales supraindividuales. Valencia: Tirant lo Blanch, 1999.

CORREIA, Eduardo. Direito penal e direito de mera ordenação social. In: INSTITUTO DE DIREITO PENAL ECONÓMICO E EUROPEU - FACULDADE DE DIREITO DA UNIVERSIDADE DE COIMBRA. Direito penal económico e europeu: textos doutrinários. Coimbra: Coimbra, 1998, V. I, pp. 3-18.

COSTA, Helena Regina Lobo da. Proteção penal ambiental: viabilidade, efetividade, tutela por outros ramos do direito. São Paulo: Saraiva, 2010.

COSTA, José de Faria. Direito penal económico. Coimbra: Quarteto, 2003.

A globalização e o direito penal (ou o tributo da consonância ao elogio da incompletude). In: Globalização e Direito - Boletim da Faculdade de Direito, Coimbra, Stvdia Ivridica 73, colloquia 12, 2003, pp.181-190.

O perigo em direito penal. Coimbra: Coimbra, 1992. 
CUNHA, Fernando Whitaker da. Globalização e direito constitucional (a limitação do poder constituinte). In: Globalização e Direito - Boletim da Faculdade de Direito, Coimbra, Stvdia Ivridica 73, colloquia 12, 2003, pp. 23-34.

CUNHA, Maria da Conceição Ferreira da. Constituição e crime: uma perspectiva da criminalização e da descriminalização. Porto: Universidade Católica Portuguesa, 1995.

CUNHA, Paulo Ferreira da. A constituição do crime: da substancial constitucionalidade do Direito Penal. Coimbra: Coimbra, 1998.

D’AVILA, Fábio Roberto. Aproximações à teoria da exclusiva proteção de bens jurídicos no direito penal contemporâneo. Revista Brasileira de Ciências Criminais, São Paulo, n. 80 , set.-out. 2009 , pp. 7-34.

Direito penal e direito sancionador: sobre a identidade do direito penal em tempos de diferença. Revista Brasileira de Ciências Criminais, São Paulo, n. 60, mai.-jun. 2006, pp. 9-35.

. O modelo de crime como ofensa ao bem jurídico. Elementos para a legitimação do direito penal secundário. In: D’AVILA, Fabio Roberto \& SOUZA, Paulo Vinicius Sporleder (Coordenadores). Direito penal secundário: estudos sobre crimes econômicos, ambientais, informáticos e outras questões. São Paulo: Revista dos Tribunais; Coimbra: Coimbra Editora, 2006, pp. 71-96.

. Ofensividade e crimes omissivos próprios: contributo à compreensão do crime como ofensa ao bem jurídico. Coimbra: Coimbra, 2005.

DE LA CUESTA AGUADO, Paz Mercedes et all. Derecho penal económico. Mendoza: Ediciones Jurídicas Cuyo, 2003.

DERANI, Cristiane. Direito ambiental econômico. São Paulo: Max Limonad, 2001.

DIAS, Augusto Silva. "What if everybody did it?": sobre a "(in)capacidade de ressonância" do direito penal à figura da acumulação. Revista Portuguesa de Ciência Criminal, ano 13, n 3, jul./set. 2003, pp. 303-345.

DIAS, Jorge de Figueiredo. O direito penal entre a "sociedade industrial" e a "sociedade do risco". Revista Brasileira de Ciências Criminais, São Paulo, n. 33, 2001, pp. 39-65.

Direito Penal: parte geral: tomo I: questões fundamentais: a doutrina geral do 
crime. São Paulo: Revista dos Tribunais; Coimbra: Coimbra Editora, 2007.

- O movimento da descriminalização e o ilícito de mera ordenação social. In:

INSTITUTO DE DIREITO PENAL ECONÓMICO E EUROPEU - FACULDADE DE

DIREITO DA UNIVERSIDADE DE COIMBRA. Direito penal económico e europeu:

textos doutrinários. Coimbra: Coimbra, 1998, V. I, pp. 19-33.

O papel do direito penal na protecção das gerações futuras. In: INSTITUTO DE

DIREITO PENAL ECONÓMICO E EUROPEU - FACULDADE DE DIREITO DA

UNIVERSIDADE DE COIMBRA. Direito penal económico e europeu: textos doutrinários. Coimbra: Coimbra, 2009, V. III, pp. 603-614.

. Sobre a tutela jurídico-penal do ambiente - um quarto de século depois. In: DIAS,

Jorge de Figueiredo et all (Orgs.). Estudos em homenagem a Cunha Rodrigues, v. I. Coimbra: Coimbra, 2001, pp. 371-392.

\& ANDRADE, Manuel da Costa. Problemática geral das infrações contra a economia nacional. In: INSTITUTO DE DIREITO PENAL ECONÓMICO E EUROPEU - FACULDADE DE DIREITO DA UNIVERSIDADE DE COIMBRA.

Direito penal económico e europeu: textos doutrinários. Coimbra: Coimbra, 1998, V. I, pp. 319-346.

DÍEZ RIPOLLÉS, José Luis. El derecho penal simbólico y los efectos de la pena. Actalidad Penal, Madrid, fasc. 1, 2001, pp. 1-22.

A racionalidade das leis penais: teoria e prática. Trad. Luiz Regis Prado. São Paulo: Revista dos Tribunais, 2007.

DI PIETRO, Maria Sylvia Zanella (Org.). Direito regulatório: temas polêmicos. Belo Horizonte: Forum, 2003.

DOLCINI, Emilio. Sui rapporti fra técnica sanzionatoria penale e amministrativa. Rivista Italiana di Diritto e Procedura Panale, Milano, v. 30, 1987, pp. 777-797.

\& MARINUCCI, Giorgio. Constituição e escolha de bens jurídicos. Revista Portuguesa de Ciência Criminal, ano 4, fasc. 2, 1994, pp. 151-198.

ESTELLITA, Heloisa. Aspectos processuais penais da responsabilidade penal da pessoa jurídica prevista na Lei ${ }^{\circ}$ 9.605/98 à luz do devido processo legal. In: VILARDI, Celso 
Sanchez; PEREIRA, Flávia Rahal Bresser \& DIAS NETO, Theodomiro (Coords.). Crimes econômicos e processo penal. São Paulo: Saraiva, 2008, pp. 205-248.

FABRI, Andréa Queiroz. Falhas de mercado: por uma nova visão do planejamento econômico. In: Direito econômico - evolução e institutos: obra em homenagem ao professor João Bosco Leopoldino da Fonseca. Rio de Janeiro: Forense, 2009, pp. 53-64.

FARIA, José Eduardo. O direito na economia globalizada. São Paulo: Malheiros, 2004.

FEIJOO SÁNCHEZ, Bernardo. Cuestiones actuales de derecho penal económico. Montevideo-Buenos Aires: B de F, 2009.

Sanciones penales y prevención de delitos socioeconómicos. In: BOIX REIG, Javier (Dir.) \& LLORIA GARCIA, Paz (Coord.). Diccionario de derecho penal económico. Madrid: Iustel, 2008, p. 843-852.

FEINBERG, Joel. The moral limits of the criminal law: harm to others. Oxford: Oxford University Press, 1987, V. One.

FELDENS, Luciano. Tutela penal de interesses difusos e crimes de colarinho branco. Porto Alegre: Livraria do Advogado, 2002.

\& SCHMIDT, Andrei Zenkner. A associação entre o ilícito administrativo e o ilícito penal no exemplo do crime de evasão de divisas. In: OSÓRIO, Fábio Medina. Direito sancionador: sistema financeiro nacional. Belo Horizonte: Fórum, 2007, pp. 191-233.

FERNANDES, Paulo Silva. Globalização, "sociedade de risco" e o futuro do direito penal: panorâmica de alguns problemas comuns. Coimbra: Almedina, 2001.

FERRAJOLI, Luigi. Derecho y razón: teoria del garantismo penal. Madrid: Trotta, 1987.

FERRARI, Eduardo Reale. A ilegitimidade da criminalização de condutas atentatórias ao meio ambiente. In: ANDRADE, Manuel da Costa et all. Liber discipulorum para Jorge de Figueiredo Dias. Coimbra: Coimbra, 2003, pp. 1185-1203.

- Legislação penal antitruste: direito penal econômico e sua concepção constitucional. In: REALE, Miguel; REALE JÚNIOR, Miguel \& FERRARI, Eduardo Reale. Experiências do direito. Campinas: Millennium, 2004, pp. 253-315.

FERREIRA, Sergio de Andréa. Direito da regulação econômica: a experiência brasileira. 
In: Globalização e Direito - Boletim da Faculdade de Direito, Coimbra, Stvdia Ivridica 73, colloquia 12, 2003, pp. 49-124.

FIANDACA, Giovanni \& FRANCOLINI, Giovanni (a cura di). Sulla legittimazione del diritto penale: culture europeo-continentale e anglo-americana a confronto. Torino: G. Giappichelli, 2008.

FORGIONI, Paula A. Direito concorrencial e restrições verticais. São Paulo: RT, 2010. Os fundamentos do antitruste. São Paulo: RT, 2008.

FRANCO, Alberto Silva. Globalização e criminalidade dos poderosos. Revista Brasileira de Ciências Criminais, São Paulo, n. 31, 2000, pp. 102-136.

Globalização e os riscos ao sistema penal brasileiro. AIDP - Publicação Oficial do Grupo Brasileiro da Associação Internacional de Direito Penal, ano 5, n. 5, 2009, pp. 3-6.

- Na expectativa de um novo paradigma. In: ANDRADE, Manuel da Costa; ANTUNES, Maria João \& SOUSA, Susana Aires (orgs.). Estudos em homenagem ao prof. doutor Jorge de Figueiredo Dias. Coimbra: Coimbra, 2009, V. I, pp. 323-346.

Novas tendências do direito penal. Boletim IBCCRIM, São Paulo, n. 56, 1997, p. 02 .

. Do princípio da intervenção mínima ao princípio da máxima intervenção. Justiça e Democracia, n. 1, 1996, pp. 167-175.

GALBRAITH, John Kenneth. 1929 - o colapso da bolsa. Trad. Oswaldo Chiquetto. São Paulo: Livraria Pioneira, 1988.

GAMEIRO, João Augusto Prado da Silveira. O tratamento penal do cartel de empresas no ordenamento jurídico brasileiro. Dissertação (Mestrado em Direito) Faculdade de Direito da Universidade de São Paulo, São Paulo, 2007.

GARCIA, Basileu. Instituições de direito penal. São Paulo: Saraiva, 2008, v. I, tomo I.

GARCIA AMADO, Juan Antonio. La filosofia del derecho de Habermas y Luhmann. Bogotá: Universidad Externado de Colombia, 1999.

GARCÍA CAVERO, Percy. Derecho penal económico: parte general. Tomo I. Lima: 
Grijley, 2007.

GARCÍA-PABLOS DE MOLINA, Antonio. Derecho penal - introducción. Madrid: Servicio Publicaciones Faculdad Derecho Universidad Complutense Madrid, 2000. . Introducción al derecho penal. Madrid: Editorial Universitaria Ramon Areces, 2006.

GARCÍA RIVAS, Nicolás. Delito ecológico - estrutura y aplicación judicial. Barcelona: Praxis, 1998.

GIDDENS, Anthony. As conseqüências da modernidade. Trad. Raul Fiker. São Paulo: UNESP, 1991.

\& BECK, Ulrich \& LASH, Scott. Modernização reflexiva: política, tradição e estética na ordem social moderna. Trad. Magda Lopes. São Paulo: UNESP, 1997.

GIMBERNAT ORDEIG, Enrique. Conceito e método da ciência do direito penal. Trad. José Carlos Gobbis Pagliuca. São Paulo: Revista dos Tribunais, 2002.

GLÓRIA, Daniel Firmato de Almeida. Direito do consumidor e direito da concorrência. In: OLIVEIRA, Amanda Flávio de. Direito econômico: evolução e institutos. Rio de Janeiro: Forense, pp. 179-207.

GOMES, Luiz Flávio. Princípio da ofensividade no direito penal. São Paulo: Revista dos Tribunais, 2002.

GOMES, Mariângela Gama de Magalhães. O princípio da proporcionalidade no direito penal. São Paulo: Revista dos Tribunais, 2003.

GÓMEZ TOMILLO, Manuel. Derecho administrativo sancionador. Parte general. Teoría general y práctica del derecho penal administrativo. Navarra: Aranzadi, 2008.

GONZAGA, João Bernardino. A inquisição em seu mundo. São Paulo: Saraiva, 1993.

GONZÁLEZ, Ventura. Nociones generales sobre derecho penal económico. Mendoza: Ediciones Jurídicas Cuyo, 1998.

GRACIA MARTÍN, Luis. Prolegómenos para la lucha por la modernización y expansión del derecho penal y para la crítica del discurso de resistencia. Valencia: Tirant lo Blanch, 2003. 
GRAU, Eros Roberto. O direito posto e o direito pressuposto. São Paulo: Malheiros, 2005. . A ordem econômica na Constituição de 1988. São Paulo: Malheiros, 2007.

GRECO, Luís. Breves reflexões sobre os princípios da proteção de bens jurídicos e da subsidiariedade no direito penal. In: SCHMIDT, Andrei Zenkner. Novos rumos do direito penal contemporâneo: livro em homenagem ao Prof. Dr. Cezar Roberto Bitencourt. Rio de Janeiro: Lumen Juris, 2006, pp. 401-426.

. "Princípio da ofensividade" e crimes de perigo abstrato - uma introdução ao debate sobre o bem jurídico e as estruturas do delito. Revista Brasileira de Ciências Criminais, São Paulo, n. 49, 2004, pp. 89-148.

. Proteção de bens jurídicos e crueldade com animais. Revista Liberdades, n. 3, jan.abr. 2010, pp. 47-59.

GULLO, Roberto Santiago Ferreira. Direito penal econômico. Rio de Janeiro: Lumen Iuris, 2001.

HABERMAS, Jürgen. Agir comunicativo e razão descentralizada. Trad. Lucia Aragão. Rio de Janeiro: Edições Tempo Brasileiro, 2001.

Consciência moral e agir comunicativo. Trad. Guido Antonio de Almeida. Rio de Janeiro: Edições Tempo Brasileiro, 1989.

HASSEMER, Winfried. La autocomprensión de la ciencia del derecho penal frente a las exigencias de su tiempo. Trad. María del Mar Diaz Pita. In: MUÑOZ CONDE, Francisco (Coord.). La ciencia del derecho penal ante el nuevo milenio. Valencia: Tirant lo Blanch, 2004.

. Crisis y características del moderno derecho penal. Trad. Francisco Muñoz Conde. Actualidad Penal, Madrid, n. 43, fasc. 2, nov. 1993, pp. 635-646.

. Crítica al derecho penal de hoy. Trad. Patricia S. Ziffer. Bogotá: Universidad Externado de Colombia, 2001.

. Fundamentos del derecho penal. Trad. Francisco Muñoz Conde y Luis Arroyo Zapatero. Barcelona: Bosch Casa Editorial, 1984.

- História das idéias penais na Alemanha do pós-guerra. Trad. Carlos Eduardo Vasconcelos. Revista Brasileira de Ciências Criminais, São Paulo, n. 6, 1994, pp. 3671. 
Persona, mundo y responsabilidad: bases para una teoria de la imputación en derecho penal. Trad. Francisco Muñoz Conde y María del Mar Díaz Pita. Bogotá: Temis, 1999.

_. Perspectivas del derecho penal futuro. Revista Penal, Huelva, v. 1, 1998, pp. 37-41. - Perspectivas de uma moderna política criminal. Trad. Cezar Roberto Bitencourt. Revista Brasileira de Ciências Criminais, São Paulo, n. 08, p. 49, out.-dez. 1994, pp. 41-51.

¿Puede haber delitos que no afecten a um bien jurídico penal? In: HEFENDEHL, Roland (Ed.). La teoría del bien jurídico: ¿ fundamento de legitimación del derecho penal o juego de abalorios dogmático? Madrid: Marcial Pons, 2007, pp. 95-104.

A que metas pode a pena estatal visar? Justitia, São Paulo, n. 48, 1986, pp. 26-31.

La responsabilidad por el producto en el derecho penal. Valencia: Tirant lo Blanch, 1995.

\& MUÑOZ CONDE, Francisco. Introducción a la criminologia y al derecho penal. Valencia: Tirant lo Blanch, 1989.

HEFENDEHL, Roland (Ed.). La teoría del bien jurídico: ¿ fundamento de legitimación del derecho penal o juego de abalorios dogmático? Madrid: Marcial Pons, 2007.

HIRSCH, Andrew Von. El concepto de bien jurídico y el "principio del daño". In: HEFENDEHL, Roland (Ed.). La teoría del bien jurídico: ¿ fundamento de legitimación del derecho penal o juego de abalorios dogmático? Madrid: Marcial Pons, 2007, pp. $37-$ 52.

I concetti di "danno" e "molestia" come criteri politico-criminali nell' ambito della dottrina penalistica angloamericana. In: FIANDACA, Giovanni \& FRANCOLINI, Giovanni (a cura di). Sulla legittimazione del diritto penale: culture europeocontinentale e anglo-americana a confronto. Torino: G. Giappichelli, 2008, pp. 29-42.

HORMAZABAL MALARÉE, Hernán. Bien jurídico y estado social e democratico de derecho: el objeto protegido por la norma penal. Santiago de Chile: CONOSUR, 1992.

HOUAISS, Antônio \& VILLAR, Mauro de Salles. Dicionário Houaiss da língua portuguesa. Rio de Janeiro: Objetiva, 2001. 
HUNGRIA, Nelson. Dos crimes contra a economia popular e das vendas a prestações com reserva de dominio. Rio de Janeiro: Livraria Jacinto, 1939.

. Os crimes contra a economia popular e o intervencionismo do Estado. Revista Forense, Rio de Janeiro, jul.1939, pp. 45-48.

INTERNACIONAL ASSOCIATION OF PENAL LAW. Eletronic Review of the International Association of Penal Law. Referência: e-RIAPL 2007. Disponível em: <http://www.penal.org/pdf/ReAIDP2007/RICPL\%201984.pdf>. Acesso em: 12 ago. 2009.

JAKOBS, Günther. O que protege o Direito Penal: os bens jurídicos ou a vigência da norma? Trad. Nereu José Giacomolli. In: CALLEGARI, André Luís \& GIACOMOLLI, Nereu José (Coords.). Direito penal e funcionalismo. Porto Alegre: Livraria do Advogado, 2005, pp. 31-52.

_ Tratado de direito penal: teoria do injusto penal e culpabilidade. Trad. Gercélia Batista de Oliveira Mendes e Geraldo de Carvalho. Belo Horizonte: Del Rey, 2009.

JIMÉNEZ DE ASÚA, Luis. Introducción al derecho penal. Ciudad de México: Jurídica Universitária, 2002, v. 1.

KAUFMANN, Arthur. Filosofia del derecho. Trad. Luis Villar Borda y Ana María Montoya. Bogotá: Universidad Externado de Colombia, 2002.

KENNEDY, Paul. Ascensão e queda das grandes potências: transformação econômica e conflito militar de 1500 a 2000. Rio de Janeiro: Campus, 1989.

KUHLEN, Lothar. ¿Es posible limitar el derecho penal por médio de um concepto material de delito? Trad. Pablo Sánchez-Ostiz Gutiérrez. In: El sistema integral del derecho penal: delito, determinación de lapena y proceso penal. Madrid: Marcial Pons Ediciones Jurídicas y Sociales, 2004, pp. 129-152.

. Necesidad y límites de la responsabilidad penal por el producto. Trad. María Martín Lorenzo e Iñigo Ortiz de Urbina Gimeno. Anuario de derecho penal y ciencias penales, Madrid, Tomo LV, MMII, 2004, pp. 67-90.

LARENZ, Karl. Metodologia da ciência do direito. Trad. Marcelino Rodriguez Molinero. Barcelona: Editorial Ariel, 1980. 
LISZT, Franz von. Tratado de direito penal alemão. Trad. José Higino Duarte Pereira. Campinas: Russell, 2003, t. I.

LUHMANN, Niklas. El concepto de riesgo. In: BERIAIN, Josetxo (Org.). Las consecuencias perversas de la modernidad. Barcelona: Anthropos, 1996, pp. 123-154. . Introdução à teoria dos sistemas. Trad. Ana Cristina Arantes Nasser. Petrópolis: Vozes, 2009. . Sociologia do direito I. Trad. Gustavo Bayer. Rio de Janeiro: Tempo Brasileiro, 1983.

LUISI, Luiz. Os princípios constitucionais penais. Porto Alegre: Sérgio Antonio Fabris Editor, 1991.

LYRA, Roberto. Crimes contra a economia popular: legislação - doutrina - jurisprudência. Rio de Janeiro: Livraria Jacinto, 1940.

MACHADO, Fábio Guedes de Paula. Crise do direito penal. Revista dos Tribunais, São Paulo, n. 765, 1999, pp. 417-435.

MACHADO, Marta Rodriguez de Assis. Sociedade do risco e direito penal: uma avaliação de novas tendências político-criminais. São Paulo: IBCCRIM, 2005.

MALHEIROS FILHO, Arnaldo. Crimes contra o sistema financeiro na virada do milênio. Boletim IBCCRIM, São Paulo, n. 83, outubro/1999, pp. 5-6.

MANES, Vittorio. Il principio di ofensività nel diritto penale: canone di politica criminale, criterio ermeneutico, parametro di ragionevolezza. Torino: G. Giappichelli, 2005.

MARQUES, José Frederico. Direito penal econômico - princípios sobre a interpretação de suas normas - do conceito de monopólio. Revista Forense, n. 215, 1965, p. 48 e ss.

MARQUES, Oswaldo Henrique Duek Marques. Fundamentos da pena. São Paulo: Martins Fontes, 2008.

MARQUES NETO, Floriano Azevedo. A nova regulação estatal e as agências independentes. In: SUNDFELD, Carlos Ari (Coord.). Direito administrativo econômico. São Paulo: Malheiros, 2006, pp. 72-98.

MARTÍNEZ-BUJÁN PÉREZ, Carlos. Derecho penal económico y de la empresa. Parte general. Valencia: Tirant lo Blanch, 2007.

MARTINS, Eliezer Pereira. Polícia administrativa econômica. CARDOZO, José Eduardo 
Martins et all (Orgs.). Curso de direito administrativo econômico. São Paulo: Malheiros, 2006, V. II, pp. 344-381.

MAXIMILIANO, Carlos. Hermenêutica e aplicação do direito. Rio de Janeiro: Forense, 2007.

MÉNDEZ RODRÍGUEZ, Cristina. Los delitos de peligro y sus técnicas de tipificación. Madrid: Montano, 1993.

MENDOZA BUERGO, Blanca. El derecho penal en la sociedad del riesgo. Madrid: Civitas, 2001.

MESEGUER YEBRA, Joaquín. La tipicidad de las infracciones en el procedimiento administrativo sancionador. Barcelona: Bosch, 2001.

MILL, John Stuart. A liberdade: utilitarismo. Trad. Isaiah Berlin. São Paulo: Martins Fontes, 2000.

MIR PUIG, Santiago. Derecho penal: parte general. Montevideo-Buenos Aires: B de F, 2005.

_. Introducción a las bases del derecho penal. Montevideo-Buenos Aires: B de F, 2002.

MOCCIA, Sergio. La perenne emergenza. Nápoles: Edizioni Scientifiche Italiane, 1997.

MONDACA, Luís S. Cabral de. Direito económico. Coimbra: Coimbra, 2007.

MONTE, Elio Lo. Principios de derecho penal tributario. Motevideo-Buenos Aires: B de F, 2006.

MONTE, Mario Ferreira. Da proteção penal do consumidor: o problema da (des)criminalização no incitamento ao consumo. Coimbra: Almedina, 1996.

MÜLLER-TUCKFELD, Jens Christian. Ensayo para la abolición del derecho penal del medio ambiente. Trad. Elena Íñigo Corroza, Nuria Pastor Muñoz y Ramon Ragués i Vallès. La insustenible situación del derecho penal. Granada: Comares, 2000, pp. 507530.

MUÑOZ CONDE, Francisco. Direito penal e controle social. Trad. Cíntia Toledo Miranda Chaves. Rio de Janeiro: Forense, 2005. 
Introducción al derecho penal. Montevideo-Buenos Aires: Editorial B de F, 2001. Teoria geral do delito. Porto Alegre: Sérgio Antonio Fabris, 1988.

MUSCO, Enzo. El nuevo derecho penal económico entre poder legislativo y poder ejecutivo. In: TERRADILLOS BASOCO, Juan María \& ACALE SÁNCHEZ, María (Coords.). Temas de derecho penal económico: III encuentro hispano-italiano de derecho penal económico. Madrid: Trota, 2004, pp.169-182.

NEVES, Marcelo. A constitucionalização simbólica. São Paulo: Editora Acadêmica, 1994.

NIETO GARCÍA, Alejandro. Derecho administrativo sancionador. Madrid: Tecnos, 2008.

NOGUEIRA, Ruy Barbosa. Curso de direito tributário. São Paulo: Saraiva, 1995.

NUSDEO, Fábio. Curso de economia: introdução ao direito econômico. São Paulo: Revista dos Tribunais, 2008.

OSÓRIO, Fábio Medina. Direito administrativo sancionador. São Paulo: Revista dos Tribunais, 2010.

PADOVANI, Tullio. Tutela di beni e tutela de funzioni nella scelta fra delito, contravvenzione e illecito amministrativo. Cassazione penale, Milano, n. 3, 1987, pp. 670-678.

PAGOTTO, Leopoldo Ubiratan Carreiro. Defesa da concorrência no sistema financeiro. São Paulo: Singular, 2006.

PALAZZO, Francesco C. Valores constitucionais e direito penal - um estudo comparado. Trad. Gérson Pereira dos Santos. Porto Alegre: Sérgio Antonio Fabris Editor, 1989.

PASCHOAL, Janaina Conceição. Constituição, criminalização e direito penal mínimo. São Paulo: Revista dos Tribunais, 2003.

PEDRAZZI, Cesare \& COSTA JÚNIOR, Paulo José da. Direito penal societário. São Paulo: DPJ Editora, 2005.

PEREÑA PINEDO, Ignacio (Coordinación). Manual del derecho administrativo sancionador. Navarra: Ministerio de Justicia: Aranzadi, 2005. 
PÉREZ DEL VALLE, Carlos. Introducción al derecho penal económico. In: BACIGALUPO, Enrique (Dir.). Derecho penal económico. Buenos Aires: Hamurabi, 2004, pp. 29-52.

PIERANGELI, José Henrique. Códigos penais do Brasil: evolução histórica. São Paulo: Revista dos Tribunais, 2001.

Dos crimes contra a propriedade industrial (arts. 183 a 194, da Lei 9.279/96). Revista Brasileira de Ciências Criminais, São Paulo, n. 17, 1997, pp. 132-144.

PIMENTEL, Manoel Pedro. Direito penal econômico. São Paulo: Revista dos Tribunais, 1973.

PITOMBO, Antônio Sérgio Altieri de Moraes Pitombo. Considerações sobre o crime de gestão temerária de instituição financeira. In: SALOMÃO, Heloisa Estellita (Coord.). Direito penal empresarial. São Paulo: Dialética, 2001, pp. 51-54.

PODVAL, Roberto. O bem jurídico do delito de lavagem de dinheiro. Revista Brasileira de Ciências Criminais, São Paulo, n. 24, 1998, pp. 209-222.

POLAINO NAVARRETE, Miguel. El bien jurídico em derecho penal. Sevilla: Publicaciones de la Universidad de Sevilla, 1974.

PONTE, Antonio Carlos da. Crimes eleitorais. São Paulo: Saraiva, 2008.

POSNER, Richard A. El análisis económico del derecho. Trad. Eduardo L. Suárez. México, D.F.: FCE, 2007.

PRADO, Luiz Regis. Bem jurídico-penal e constituição. São Paulo: Revista dos Tribunais, 1997.

. Curso de direito penal brasileiro, volume 1: parte geral, arts. $1^{\circ}$ a 120. São Paulo: Revista dos Tribunais, 2004.

Curso de direito penal brasileiro, volume 4: parte especial, arts. 289 a 359-H. São Paulo: Revista dos Tribunais, 2004.

Direito penal econômico. São Paulo: Revista dos Tribunais, 2004.

(Coord.). Responsabilidade penal da pessoa jurídica - em defesa do princípio da imputação penal subjetiva. São Paulo: Revista dos Tribunais, 2001. 
PRADO JÚNIOR, Caio. História econômica do Brasil. São Paulo: Brasiliense, 1970.

QUEIROZ, Paulo de Souza. Do caráter subsidiário do direito penal. Belo Horizonte: Del Rey, 2002.

. Funções do direito penal: legitimação versus deslegitimação do sistema penal. Belo Horizonte: Del Rey, 2001.

QUINTERO OLIVARES, Gonzalo. Adonde va el derecho penal: reflexiones sobre las leyes penales y los penalistas españoles. Madrid: Civitas, 2004.

REALE, Miguel. Crise do capitalismo e crise do estado. São Paulo: SENAC, 2000. . Filosofia do Direito. São Paulo: Saraiva, 1995. . Lições preliminares de Direito. São Paulo: Saraiva, 1995.

REALE JÚNIOR, Miguel. Antijuridicidade concreta. São Paulo: José Bushatsky, 1973. . Cartel e quadrilha ou bando: bis in idem. Revista de Ciências Penais, São Paulo, n. 5, pp.131-143.

. Casos de direito constitucional. São Paulo: Revista dos Tribunais, 1992.

. Concorrência desleal e interesse difuso no direito brasileiro. Revista de Direito Penal e Criminologia, Rio de Janeiro, n. 33, 1982, pp. 159-169.

. Crime organizado e crime econômico. Revista Brasileira de Ciências Criminais, São Paulo, n. 13, 1996, pp. 182-190.

. Despenalização no direito penal econômico: uma terceira via entre o crime e a infração administrativa? Revista Brasileira de Ciências Criminais, São Paulo, n. 28, 1999, pp. 116-129.

. Dever de lealdade do administrador da empresa e direito penal. In: REALE, Miguel; REALE JÚNIOR, Miguel \& FERRARI, Eduardo Reale. Experiências do direito. Campinas: Millennium, 2004, pp. 229-252.

. Dos estados de necessidade. São Paulo: Bushatsky, 1971.

. Ilícito administrativo e o jus puniendi geral. In: PRADO, Luiz Regis (Coord.). Direito penal contemporâneo: estudos em homenagem ao professor José Cerezo Mir. 
São Paulo: Revista dos Tribunais, 2007, pp. 93-100. . Instituições de direito penal - parte geral. Rio de Janeiro: Forense, 2009. . Parte geral do código penal. São Paulo: Revista dos Tribunais, 1988. . Problemas penais concretos. São Paulo: Malheiros, 1997. . Teoria do delito. São Paulo: Revista dos Tribunais, 2000.

RIBEIRO, Joaquim de Sousa. Direito dos contratos e regulação do mercado. In: Globalização e Direito - Boletim da Faculdade de Direito, Coimbra, Stvdia Ivridica 73, colloquia 12, 2003, pp. 225-242.

RIGHI, Esteban. Los delitos económicos. Buenos Aires: Ad-Hoc, 2000.

RODRIGUES, Anabela Miranda. Criminalidade organizada - que política criminal? In: Globalização e Direito - Boletim da Faculdade de Direito, Coimbra, Stvdia Ivridica 73, colloquia 12, 2003, pp. 191-208.

ROXIN, Claus. Derecho penal: parte general: tomo I: fundamentos - la estructura de la teoria del delito. Trad. Diego-Manuel Luzón Peña, Miguel Díaz y García Conlledo e Javier de Vicente Remesal. Madrid: Civitas, 2008. . Funcionalismo e imputação objetiva no direito penal. Trad. Luís Greco. Rio de Janeiro: Renovar, 2002. Política criminal e sistema jurídico-penal. Trad. Luís Greco. Rio de Janeiro - São Paulo: Renovar, 2002. Problemas fundamentais de direito penal. Trad. Ana Paula dos Santos Luis Natscheradctz. Lisboa: Vega, 1986. A proteção de bens jurídicos como função do direito penal. Trad. André Luís Callegari e Nereu José Giacomolli. Porto Alegre: Livraria do Advogado, 2009. - ¿Es la protección de bienes jurídicos uma finalidad del derecho penal? In: HEFENDEHL, Roland (Ed.). La teoría del bien jurídico: ¿ fundamento de legitimación del derecho penal o juego de abalorios dogmático? Madrid: Marcial Pons, 2007, pp. 443-458. . Strafrecht. Allgemeiner Teil. Band I. Grundlagen Aufbau der Verbrechenslehre. 4. 
ed. Munique: C. H. Beck, 2006.

. Tem futuro o direito penal?, Revista dos Tribunais, n. 790, agosto de 2001, pp. 459474.

ROYSEN, Joyce. Histórico da criminalidade econômica. Revista Brasileira de Ciências Criminais, São Paulo, ano 11, n. 42, jan.-mar. 2003, pp. 192-213.

RUSSEL, Bertrand. História do pensamento ocidental: a aventura das idéias dos présocráticos a Wittgenstein. Trad. Laura Alves e Aurélio Rebello. Rio de Janeiro: Ediouro, 2002.

SALOMÃO, Heloísa Estellita. A tutela penal e as obrigações tributárias na constituição federal. São Paulo: Revista dos Tribunais, 2001.

SALOMÃO FILHO, Calixto. Apontamentos para a formulação de uma teoria jurídica dos cartéis. Revista de direito mercantil, industrial, econômico e financeiro, São Paulo, v. 40, n. 121, 2001, pp. 18-29.

- Atuação estatal e ilícito antitruste. Revista de direito mercantil, industrial, econômico e financeiro, São Paulo, v. 36, n. 106, 1997, pp. 35-47.

. Regulação da atividade econômica: princípios e fundamentos jurídicos. São Paulo: Malheiros, 2008.

SALVADOR NETTO, Alamiro Velludo. Finalidades da pena: conceito material de delito e sistema penal integral. São Paulo: Quartier Latin, 2009.

. Tipicidade penal e princípio da legalidade: o dilema dos elementos normativos e a taxatividade. Revista Brasileira de Ciências Criminais, n. 85, v. 13, jul.-ago. 2010, pp. 219-235.

. Tipicidade penal e sociedade de risco. São Paulo: Quartier Latin, 2006.

SANTANA VEGA, Dulce María. La protección penal de los bienes jurídicos colectivos. Madrid: Dikinson, 2000.

SANTOS, Cláudia Maria Cruz. O crime de colarinho branco (da origem do conceito e sua relevância criminógena à questão da desigualdade na administração da justiça penal). Coimbra: Coimbra, 2001. 
SANTOS, Juarez Cirino dos. Direito penal econômico. Revista de Direito Penal e Criminologia, Rio de Janeiro, n. 33, 1982, pp. 196-201.

Direito penal: parte geral. Curtiba: ICPC-Lumen Juris, 2008.

SCHIMIDT, Andrei Zenkner. A criminalidade moderna nas concepções de Hassemer e Silva Sánchez. Revista jurídica, Porto Alegre, v. 284, jun. 2001, pp. 62-78.

SCHMIDT, Andrei Zenkner \& FELDENS, Luciano. Os ativos declaráveis perante o Banco Central e os limites normativos do art. 22, parágrafo único, da Lei no 7.492/86. Boletim IBCCRIM, n. 217, v. 18, dez. 2010, pp. 2-3. O crime de evasão de divisas. Rio de Janeiro: Lúmen Júris, 2006.

SCHÜNEMANN, Bernd. El derecho en el proceso de la globalización económica. In: LAVEAGA, Gerardo et all (Dir.). Orientaciones de la política criminal legislativa. México, D.F.: INACIPE, 2005, pp. 3-16. - ¡El derecho penal es la ultima ratio para la protección de bienes jurídicos! Sobre los limites inviolables del derecho penal en um estado liberal de derecho. Trad. Ángela de la Torre Benítez. Bogotá: Universidad Externado de Colômbia, 2007.

O direito penal é a ultima ratio da proteção de bens jurídicos! - Sobre os limites invioláveis do direito penal em um Estado de Direito liberal. Trad. Luís Greco. Revista Brasileira de Ciências Criminais, n. 53, v. 13, 2005, pp. 7-34.

- ¿Ofrece la reforma del derecho penal económico alemán un modelo o un escarmiento? Trad. Lourdes Baza. Temas actuales y permanentes del derecho penal después del milenio. Madrid: Tecnos, 2002, pp. 185-202.

La política criminal y el sistema de derecho penal. Anuario de derecho penal y ciencias penales, Madrid, tomo XLIV, fasc. III, sep.-dic. 1991, pp. 693-713.

Responsabilidad penal en el marco de la empresa. Dificultades relativas a la individualización de la imputación. Anuario de derecho penal y ciencias penales, Madrid, tomo LV, vol. LV, 2002, pp. 9-38.

. Sobre la dogmática y la política criminal Del derecho penal del médio ambiente. Cuadernos de Doctrina y Jurisprudencia Penal, Buenos Aires, v. 5, n. 9, 1999, pp. 627-628.

SGUBBI, Filippo. El delito como riesgo social: investigación sobre las opciones em la 
asignación de la ilegalidad penal. Trad. Julio E. S. Virgolini. Buenos Aires: Editorial Ábaco de Rodolfo Depalma, 1998.

SHECAIRA, Sérgio Salomão. Criminologia. São Paulo: Revista dos Tribunais, 2004.

Responsabilidade penal da pessoa jurídica. São Paulo: Revista dos Tribunais, 1998.

SICA, Leonardo. Caráter simbólico da intervenção penal na ordem econômica. Revista do Instituto dos Advogados de São Paulo, São Paulo, n. 02, 1998, pp. 105-116.

Direito penal de emergência e alternativas à prisão. São Paulo: Revista dos Tribunais, 2002.

SILVA, Ângelo Roberto Ilha da. Dos crimes de perigo abstrato em face da constituição. São Paulo: Revista dos Tribunais, 2003.

SILVA, Eduardo Sanz de Oliveira. O princípio da subsidiariedade e a expansão do direito penal econômico. In: D’AVILA, Fábio Roberto \& SOUZA, Paulo Vinicius Sporleder de (Coords.). Direito penal secundário - estudos sobre crimes econômicos, ambientais, informáticos e outras questões. São Paulo: Revista dos Tribunais, 2006, pp. 181-215.

SILVA, José Afonso da. Curso de direito constitucional positivo. São Paulo: Malheiros, 1996.

SILVA SÁNCHEZ, Jesús-María. Aproximación al derecho penal contemporáneo. Barcelona: Bosch Editor, 2002.

. El derecho penal ante la globalización y la integración supranacional. Revista Brasileira de Ciências Criminais, São Paulo, n. 24, 1998, pp. 65-78.

. Eficiência e direito penal. Trad. Maurício Antonio Ribeiro Lopes. Barueri: Manole, 2004.

A expansão do direito penal - aspectos da política criminal nas sociedades pósindustriais. Trad. Luiz Otávio de Oliveira Rocha. São Paulo: Revista dos Tribunais, 2002.

SILVEIRA, Renato de Mello Jorge. A construção do bem jurídico espiritualizado e suas críticas fundamentais. Boletim IBCCRIM, São Paulo, n. 122, janeiro/2003, pp. 14-15. 
. Direito penal econômico como direito penal de perigo. São Paulo: Revista dos Tribunais, 2006.

- Direito penal supra-individual: interesses difusos. São Paulo: Revista dos Tribunais, 2003.

_. Fundamentos da adequação social em direito penal. São Paulo: Quartier Latin, 2010.

\& SALVADOR NETTO, Alamiro Velludo. Sarbanes-Oxley Act e os vícios do Direito Penal Globalizado. Revista Ultima Ratio, Rio de Janeiro, v. 1, n. 0, 2006, pp. 193-210.

. \& SALVADOR NETTO, Alamiro Velludo. A tutela penal do mercado de capitais e o Sarbanes-Oxley-Act: novas considerações. In: RUIZ FILHO, Antonio \& SICA, Leonardo (Coordenação). Responsabilidade penal na atividade econômicoempresarial: doutrina e jurisprudência comentada. São Paulo: Quartier Latin, 2010, pp. 371-396.

SMANIO, Gianpaolo Poggio. Tutela penal dos interesses difusos. São Paulo: Atlas, 2000.

SOUSA, Susana Aires de. Os crimes fiscais: análise dogmática e reflexão sobre a legitimidade do discurso criminalizador. Coimbra: Coimbra, 2006.

Sociedade do risco: requiem pelo bem jurídico? Revista Brasileira de Ciências Criminais, São Paulo, v. 18, n. 86, set.-out. 2010, pp. 231-246.

SOUSA NETO. Júri de economia popular: comentários à Lei no 1.521 , de 26 de dezembro de 1951. Rio de Janeiro: Forense, 1952.

SOUZA, Luciano Anderson de. Expansão do direito penal e globalização. São Paulo: Quartier Latin, 2007.

STOCCO, Rui. Abuso do poder econômico e sua repressão (mecanismos penais e administrativos). Revista Brasileira de Ciências Criminais, São Paulo, n. 11, jun.-set. 1995, pp. 208-230.

STRATENWERTH, Günther. Derecho penal: parte general: el hecho punible. Buenos Aires: Hammurabi, 2005. 
SUNDFELD, Carlos Ari (Coord.). Direito administrativo econômico. São Paulo: Malheiros, 2002.

SUTHERLAND, Edwin H. El delito de cuello blanco: versión completa. Trad. Laura Belloqui. Montevideo-Buenos Aires: B de F, 2009.

TANGERINO, Davi de Paiva Costa \& GARCIA, Denise Nunes (Coords.). Direito penal tributário. São Paulo: Quartier Latin, 2007.

TAVARES, Juarez. Teoria do injusto penal. Belo Horizonte: Del Rey, 2002.

TERRADILLOS BASOCO, Juan M. Derecho penal de la empresa. Madrid: Trotta, 1995. . Empresa y derecho penal. Buenos Aires: Ad-Hoc, 2001.

- Sistema penal y delitos contra el orden socioeconómico. Consideraciones introductorias. In: DE LA CUESTA AGUADO, Paz Mercedes et all. Derecho penal económico. Mendoza: Ediciones Jurídicas Cuyo, 2003, pp. 53-78.

\& ACALE SÁNCHEZ, María (Coords.). Temas de derecho penal económico: III encuentro hispano-italiano de derecho penal económico. Madrid: Trotta, 2004.

TIEDEMANN, Klaus. Derecho penal económico: introducción y parte general. Lima: Grijley, 2009. Leciones de derecho penal económico. Barcelona: PPU, 1993. - Poder económico y delito: introducción al derecho penal económico y de la empresa. Trad. Amelia M. Villegas. Barcelona: Ariel, 1985.

Responsabilidad penal de personas jurídicas y empresas en derecho comparado. Revista Brasileira de Ciências Criminais, São Paulo, n. 11, 1995, pp. 21-35.

TOLEDO, Gastão Alves de. Ordem econômica e financeira. In: MARTINS, Ives Gandra da Silva; MENDES, Gilmar Ferreira; NASCIMENTO, Carlos Valder do (Coords.). Tratado de direito constitucional. São Paulo: Saraiva, 2010, V. II, pp. 307-348.

UNITED STATES OF AMERICA GOVERNMENT. Sherman Anti-Trust Act (1890). Disponível em: <http://www.ourdocuments.gov/doc.php?flash=true\&doc=51>. Acesso em 14/10/2009.

WELZEL, Hans. Derecho penal alemán. Trad. Juan Bustos Ramírez e Sérgio Yáñez Pérez. 
Santiago de Chile: Editorial Juídia de Chile, 1993.

WIGGERSHAUS, Holf. A Escola de Frankfurt: história, desenvolvimento teórico, significação política. Trad. Lilyane Deroche-Gurgel e Vera de Azambuja Harvey. Rio de Janeiro: Difel, 2006.

WOHLERS, Wolfgang. Le fattispecie penale come strumento per il mantenimento di orientamenti sociali di carattere assiologico? Problemi di legittimazione da una prospettiva europea continentale e da una angloamericana. In: FIANDACA, Giovanni \& FRANCOLINI, Giovanni (a cura di). Sulla legittimazione del diritto penale: culture europeo-continentale e anglo-americana a confronto. Torino: G. Giappichelli, 2008, pp. $125-152$.

ZAFFARONI, Eugenio Raúl \& PIERANGELI, José Henrique. Manual de direito penal brasileiro. São Paulo: Revista dos Tribunais, 2008.

ZAPATERO, Luis Arroyo \& TIEDEMANN, Klaus. Estudios de derecho penal económico. Cuenca: Castilla La mancha, 1994.

ZUGALDÍA ESPINAR, José Miguel. Fundamentos de derecho penal. Valencia: Tirant lo Blanch, 1993.

ZÚÑIGA RODRÍGUEZ, Laura. Relaciones entre derecho penal y derecho administrativo sancionador ¿Hacia una "administrativización” del derecho penal o una "penalización" del derecho administrativo sancionador? In: NIETO MARTÍN, Adán (Coordinador). Homenaje al dr. Marino Barbero Santos in memoriam. Cuenca: Ediciones de la Universidad de Castilla-La Mancha: Ediciones de la Universidad de Salamanca, 2001, pp. 1417-1444. 